\title{
NATURAL HISTORY OF
}

BRMIH FISHES

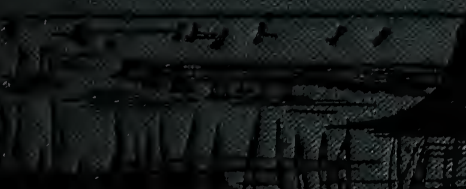

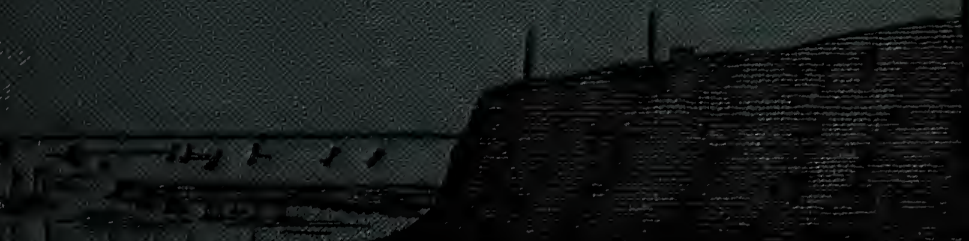

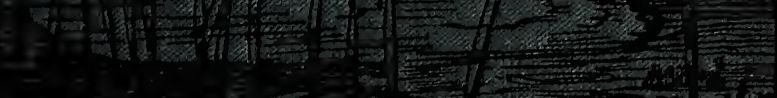

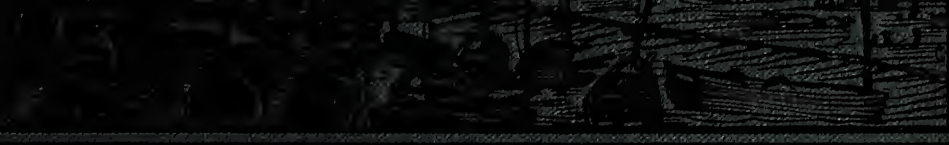

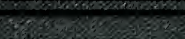

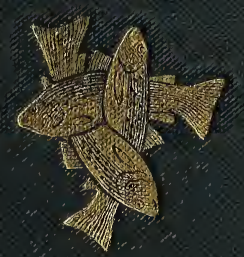

FRANK BUCKLAND 


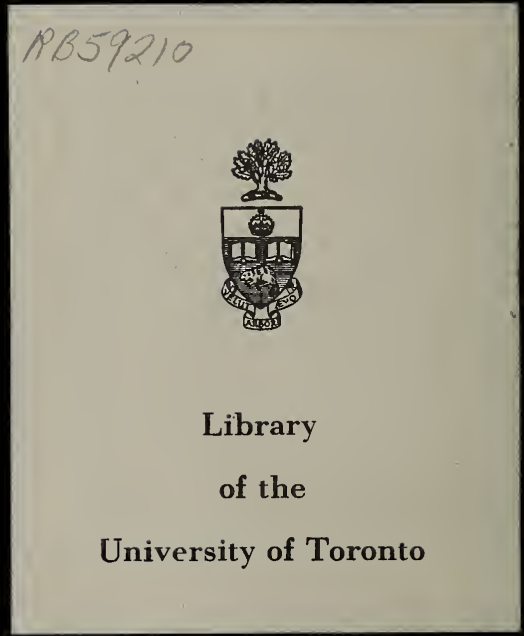


$\because$ 
$\gamma$ 
NATURAL HISTORY

oF

BRITISH FISHES。

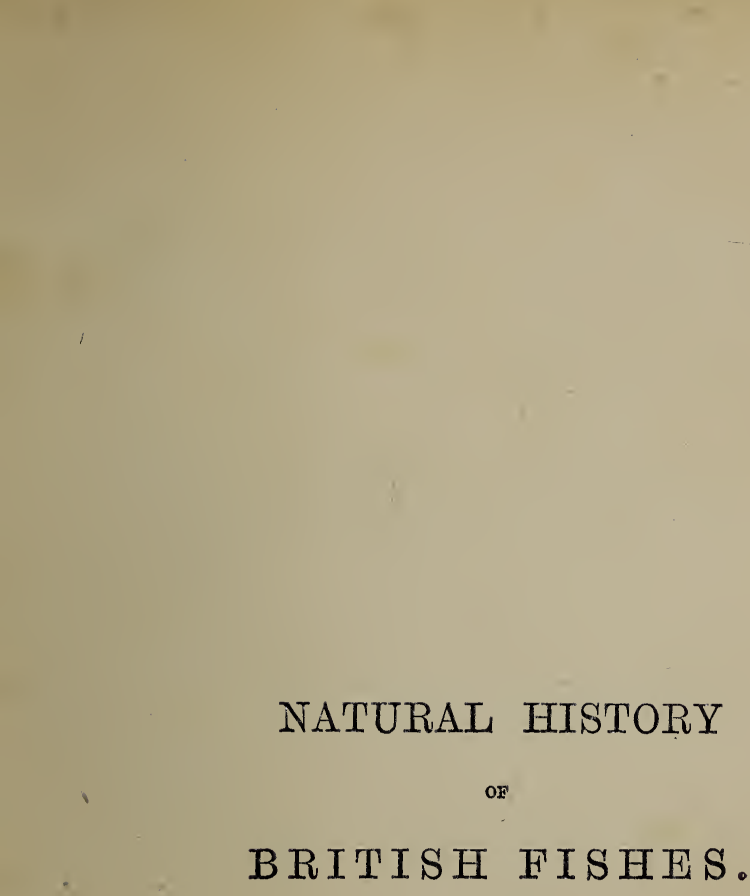





\section{NATURAL HISTORY}

OF

\section{BRITISH FISHES;}

THEIR STRUCTURE, ECONOMIC USES, AND

CAPTURE BY NET AND ROD.

CULTIVATION OF FISH-PONDS.

FISH SUITED FOR ACCLIMATISATION.

ARTIFICIAL BREEDING OF SALMON.

\section{BY \\ FRANK BUCKLAND.}

PUBLISHED CNDER THE DIRECTION OF THE COMMITTEE OF GENERAL LITERATURE AND EDUCATION, APPOINTED BY THE SOCIETY FOR PROMOTING CHRISTIAN KNOWLEDGE.

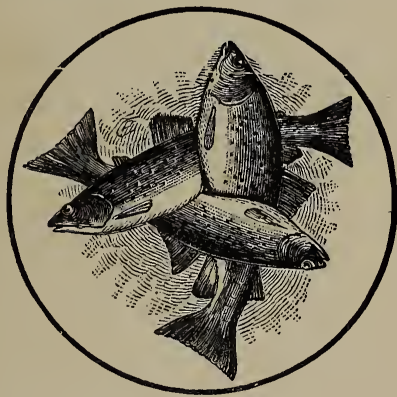

LONDON :

SOCIETY FOR PROMOTING CHRISTIAN KNOWLEDGE, NORTHUMBERLAND AVENUE, CHARING CROSS, W.C. ;

43, QUEEN VICTORIA STREET, E.C.;

26, ST. GEORGE'S PLACE, HYDE PARK CORNER, S.W. BRIGHTON: 135, NORTI STREET.

NEW YORK: E. \& J. B. YOUNG \& CO. 1883. 
UNWoN BROTHERS, THE RESH HM PRESS, CHILTORTH AND LONDON. 


\section{PREFACE.}

THe fisheries of this country-both sea and river-have now assumed such vast importance that I have great pleasure in acceding to the wish of the Committee of the Society for Promoting Christian Knowledge, to bring out a new edition of this book.

The first edition was known under the title of Familiar History of British Fishes.

Having since the publication of this book served Officially on several Government Fishery Commissions, I have lost no opportunity-whether on my travels, Inspections, or at court sittings-to obtain all possible information relative to fish and fishing. This, therefore, is not merely a book on Ichthyology, but is an introductory guide to the great and important science of fish-culture.

The general public have not, I am sure, an idea of the vast importance of this science; let them therefore for a moment consider from whence must come the enormous daily supplies, to be counted by hundreds of tons of fish, for the great markets such as Billingsgate, Liverpool, Birmingham, Manchester, Edinburgh, Glasgow, \&c. 
There are nearly four millions of mouths in London to be fed daily, and thirty-three millions of hungry subjects of Her Majesty in England, Wales, Ireland, and Scotland demand also a daily supply of fresh fish. At present this daily supply is forthcoming; but how long this is to continue without falling off is a question which makes me shudder. It is therefore the more desirable that public attention should be directed quite as much to the cultivation of the waters as it has been hitherto to the cultivation of the lands. Aquiculture is quite as important as Agriculture.

Parliament has been most generous and thoughtful in the matter of fisheries. Whenever it has been shown to them (after strict deliberation in Committee) that legislation is required, legislation has been framed accordingly. The law has now since 1862 thrown its protecting shield over our salmon fisheries in England and Wales, which (despite the carpings and grumblings of individuals) have most decidedly increased; that is to say, that many more salmon have been sent into the markets to be eaten than were forthcoming eighteen years ago.

In due course the time arrived when it was desirable that legislation should be made relative to the hitherto neglected freshwater fisheries of this country.

In $1875 \mathrm{I}$ had the honour of inspecting and reporting to Parliament on the rivers and broads of Norfolk, the fisheries of which from time immemorial had been treated in the most wasteful manner. This resulted in the Norfolk and Suffolk Fisheries Act-an Act that has already done an immense deal of good, and has caused the greatest satisfaction, not only to the inhabitants of Norfolk and Suffolk, but also to the angling communities of most of our great manufacturing towns in the Londors 
and the Midland districts of England; while at the same time the supply of freshwater fish-much esteemed as food by the poor in certain parts of England-will be vastly increased.

In 1878 this Act of Parliament was followed by another Freshwater Fisheries Act, protecting our Rivers, Lakes, Ponds, Canals, \&c.

To the Right Hon. A. Mundella, M.P. for Sheffield, the public are indebted for the great pains and trouble he gave in obtaining this boon for society. (See Abstract of this Act, page 376.)

Parliament has also legislated upon other matters, and laws now exist (necessity having been shown) relative to the preservation of Crabs, Lobsters, and Oysters.

Our information relative to the habits of Sea Fish is not as yet quite complete enough to warrant our asking Parliament for legislation.

It would be in vain for me to attempt to give any value of the British Fisheries; suffice it to say, they are worth many hundred thousands a year.

Bordering the great North Sea alone, there are several important fishing ports; such as Yarmouth, Lowestoft, Hull, Grimsby, Scarborough, \&c. Over 2,000 trawling-smacks and an army of brave fishermen are incessantly, day and night, all the year round, fishing with their heavy trawl nets the vast sand plateaus of the 140,000 square miles of the great North Sea.

The natural conditions of the bottom of this great North Sea is in a scientific sense less known than the deserts of Sahara. Yet this "Great Fish Farm" of Her Majesty's subjects is practically more important than the recent revelations made at a vast expense to the country of the abyssal depths of far distant oceans. 
In the published sailing charts, some slight descriptions of the fishing-grounds of the North Sea are given, but the information is painfully meagre. Thus we find the composition of the vast submarine valleys and plains described as follows:- " Fine sand-white shells -brown sand and black specks-coarse sand and reddish gravel - white ross-fine whity-brown sandrubbish-oyster shells-and a substance similar to grapes-substances resembling white plums-sand, with a mixture of mud-soundings resembling biscuit dust-coarse gravelly soundings-white muddy soundings-black and grey stones-yellowish coarse bottom -greyish coarse sand-red sandy soundings-rubbish and scruff." (Moor-log from the Texel ground.)

These soundings are without doubt of the greatest service to fishermen in ascertaining their whereabouts in the North Sea; but how much more interesting would it be if the real consistency (in a natural history sense) of the bottom of the North Sea became for the first time a subject of investigation and knowledge.

This knowledge obtained, practical results to the fishermen themselves would follow; for when their observations have been carefully recorded, consolidated, and deductions made therefrom, we shall be enabled, with much greater accuracy than at present, to predi. cate the times and places at which the shoals of fish (whether round fish or flat) assemble or disperse, according to the instinct given them by the Great Creator.

We want also to know more about the balance of life, or, as Professor Owen so ably called it, the "Policy of Nature," going on in the depths of the ocean-that is to say, what is the exact meaning of the ravages on 
sea fish by the "finner" whales, the grampuses, porpoises, the carnivorous fishes, and the great army of sea birds.

We also want to know the times and places of the spawning of sea fish. Where do the soles lay their eggs? When and how do the plaice, turbot, brill, halibut, \&c., spawn? Do cods' eggs sink or swim ? What is the form and dimensions of the young sole just hatched from the egg? We know, moreover, as yet but very little of the food of these tishes, of what it consists, how, when, and where grown, obtained, \&c.

The subject of ocean temperature as affecting the great migratory armies of herrings, cod, \&c., is little if at all known, but is yet of the utmost commercial importance.

Again, how are we to devise a mesh of net that shall let go the small soles and under-sized fry of other fish, keeping the marketable fish only, allowing the others to escape and grow.

Thus it will be seen that we have a huge field of inquiry before us, the results of which will not assume the form of a scientific plaything, but of a key which we hope may unlock the mysteries of the vast ocean. The results obtained will also, I trust, bring out facts which will run counter to certain modern ideas of creation, prompted, I fear, by pride of intellect, which cannot humble itself enough to accept on faith itself the fact that "The sea is His, and $\mathrm{He}$ made it, and His hand prepared the dry land."

Seeing the necessity of obtaining knowledge on these points, with the combined assistance of my colleague, Mr. Spencer Walpole, and some gentlemen residing at Great Grimsby, especially Mr. O. T. Olsen, nautical instrument maker of that town, we have instituted a 
"North Sea Prize Fisheries Committee," and have issued Log-books to be filled up by the working masters of the trawlers themselves. The log-books for 1879-80 have already been sent in, and we propose to distribute the prizes on December 27, 1880, for the best recorded observations.*

I have another object in writing this book; it is to endeavour to show the truth of the good old doctrines of the Bridgwater Treatises, which have so ably demonstrated the "Power, wisdom, and goodness of God, as manifested in the Creation."

Of late years the doctrines of so-called "Evolution" and "Development" have seemingly gained ground amongst those interested in natural history ; but I have too much faith in the good sense and natural acumen of my fellow countrymen to think that these tenets will be very long-lived.

To put matters very straight, I steadfastly believe that the Great Creator, as indeed we are directly told, made all things perfect and "Very Good" from the beginning; perfect and "very good" every created thing is now found to be, and will so continue to the end of time.

I am very willing to prove my case by holding a court at any time or place, before any number of people of any class. I would empanel a jury of the most eminent and skilful railway and mechanical engineers, while the only witnesses I should call would be the fish fresh from the deep-sea trawler, the City fishmarket, or the fishmonger's slab. I would adduce from them evidence of "Design, Beauty, and Order," as evinced in such as the

* I shall be pleased to send copies of our paper for the prizes of 1881 to any of my readers who would in any way feel inclined to further our objects. 
electric organs of the torpedo-the gun-lock spine of the file-fish-the water reservoirs and spectacles of the eel-the teeth of the gilthead bream, and throat-teeth of the carp, bream, \&c.-the anchor of the lumpsucker and remora-the colouring of the perch and bleak-the icthyophagous teeth of the pike, shark, and silvery hairtail-the tail of the fox shark-the prehensile lips of the dory and sprat-the nose of the barbel and dog-fish-the resplendence of the Arctic gymnetrus and scabbard-fish-the dagger in the tail of the sting ray-the nest of the stickleback-the armour plates of the sturgeon-the nostril, breathing powers, and store of fat in the salmon-migrations of the salmon, herring, pilchard, sprat, and mackerel, \&c.-and, above all, the enormous fertility of fishes useful as food to the human race.*

I am satisfied that I should obtain a verdict in favour of my view of the case, namely, that in all these wonderful contrivances, there exists evidence of design and forethought and a wondrous adaptation of means. to an end. A full acknowledgment must necessarily follow that these were due to the immediate creation of "The Lord and Giver of life."

This is a school open to all; there is never any lack of subjects, no fees to pay; all that is required is a sharp knife, sharp scissors, and painstaking observation; while the mind will reap its reward in the pleasures of original investigation.

I trust that these observations may lead many of my fellow countrymen to see how far inferior the socalled works of human art are to the works of creation; and, finally, let me assure them that they will find in the

* The above points are mentioned in this book. See Index. 
structure of animals-whether living in the waters or on the land-most perfect contrivances and artistic designs, not made by the hands of man, but by the Great Artificer who made man himself.

\section{FRANK BUCKLAND.}

37, Albany Street, Regent's Park,

17 th December, 1880.

** The lamented death of Mr. Frank Buckland two days after the date of the foregoing preface-which contains nearly, if not quite, the last words he ever wrote-and a few days before the completion of the book, renders it possible that some few errata may remain uncorrected in the following pages.

28th December, 1880. 


\section{BRITISH FISHES.}

\section{THE ANCHOVY.}

Abdominales Malacopterygii.

Clupeide.

(Clupea eucrasicholus, Engraulis eucrasicholus.)

German: Der Anchovis. Norwegian: Brisling. Dutch: Ansjovis.

The Anchovy is a fish of small size, seldom measuring above $6 \frac{1}{2} \mathrm{in}$. in length, the form slender, and tapering towards the tail ; the head long and sharp-pointed, the upper jaw being considerably the longer and the mouth

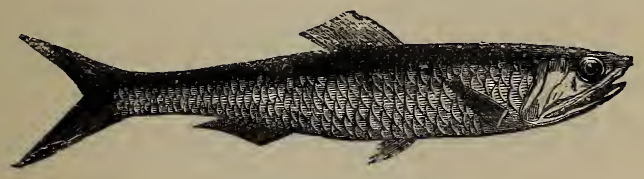

THE ANCHOVY.

very peculiarly formed. It is a most marvellous bit of machinery for catching the food, which consists of small crabs, "brett," i.e., fry and sea insects. The back is greenish blue, nearly all the other parts silvery white. I have received several specimens through the kindness of my friend Mr. Charles, Fish Merchant, Lower Grosvenor Place.

The great commercial fisheries for anchovies are in 
Sicily, the island of Elba, Corsica, Cannes, Martigues, \&c. The season is from April to July; the times, very dark nights when there is no moon. The fishing-boats carry torches (rather a poaching proceeding by the way), and when the anchovies are assembled (attracted by the light) the fishermen surround the shoal with smallmeshed nets, splash the water and make as much noise as possible, and the fish in their terror "gill" themselves in the net.

I have discovered that there formerly existed in London, and possibly may now exist, establishments where whitebait are converted into anchovy paste and anchovy sauce.

In November, 1871, Mr. Matthias Dunn, of Mevagissey, Cornwall, reported to me that the seines set in Mevagissey Bay for pilchards caught an enormous number of anchovies, estimated at 150,000. "As they could not be utilised, they were carted away as manure to the fields, for nobody seemed to know how to cure them."

Mr. Dunn writes, "It is seldom anchovies come so close in shore as these did, though countless quantities of them hang on to our coast from September till February, and in some dark nights give a beautiful phosphorescent light to the depths of the ocean." This letter of Mr. Dunn's led to a very interesting correspondence in Land and Water, vol. xvi., from which it appears that this is an industry that is quite worth a capitalist taking up, as Dutch anchovies are worth 56s. a barrel of 83ibs., and a double barrel of Gorgona anchovies of $201 \mathrm{bs}$. is worth $20 \mathrm{~s}$. In fact, the difficulty was solved in August, 1873, by my secretary, Mr. Searle, who writes: "I requested a friend, the proprietor of the 'Oriental Sauce,' to try his hand at the manufacture 
of these fish. Mr. Frank Gosden, of Exeter, sent me about $4 \mathrm{lbs}$. of anchovies; out of this quantity several bottles of sauce were made, and the result was a perfect success." All, therefore, that is wanted to start an anchovy fishery in Cornwall is a fleet of small-meshed nets, and after the fish are once caught, means could be soon found to make them into sauce and anchovy paste.

Thousands of sprats are sold in the form of anchovy paste. They are prepared in the following way: "To preserve a peck of sprats, put 2lbs. of salt, 3oz. of bay-salt, 1lb. of saltpetre, 2oz. of prunella, and a few grains of cochineal into a mortar, and pound them well together; put into a stone jar first a layer of fish, then a layer of the composition. When the jar is full, press them hard down and cover close for six months, when they will be fit for use."

We believe the anchovy of commerce as imported is only salted with coarse salt.

\section{THE ANGLER, FISHING-FROG, OR POCKET FISH.}

Acanthopteri.

(Lophius piscatorius.)

Lophiida.

French : Baudroie. German: Der Frosch-fisch. Dutch: Zee Duivel.

Is Land and Water, April 27, 1872, I published the following:- "Messrs. Gilson and Allen, fishmongers, of 7, South Colonnade, St. Leonard's-on-Sea, and 19, Haymarket, London, have kindly sent me a monster Fishing-frog, or Angler Fish (Lophius piscatorius). The total length of this fine fellow was, from nose to end of tail, 4 feet 7 inches; width across 
widest part, 2 feet 10 inches. I put a rope through his lower jaw, and my boy John and myself tried to haul him up. The rope broke, and he fell down, a great flabby mass, on to the stones of the area. I had no scales to weigh him. I then sent for a new rope, and hauled him up with great difficulty, the rope, which very nearly broke in two, being passed over the open door of the coal-cellar. In this attitude his mouth was

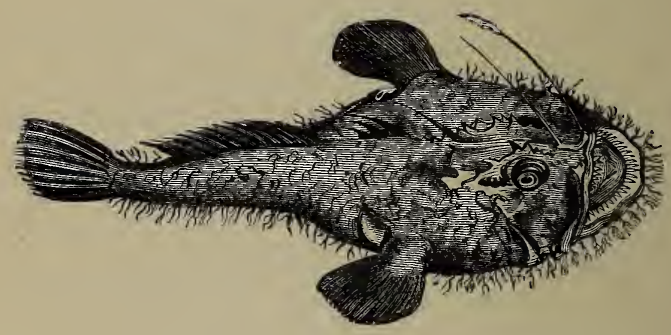

THE ANGLER.

something wonderful to behold. It measured across the widest gape no less than 1 foot 2 inches, and from one corner of the mouth to the other 1 foot 2 inches.

"Through this monster mouth one looks into an abyss. of throat which, measured by a stick, turns out to be no less than 1 foot 10 inches deep. Not liking to lose the preparation altogether, I sent for the pepper-box, and gave his throat a good peppering. I then sent for a sack of sawdust, and began to fill him with sawdust, using a broom-handle as a ramrod. I had just finished charging his stomach, which held a bucketful of sawdust, when my operations were suddenly put a stop to. The large fish was, in fact, rather stinking; and I had buried my friend all the previous night in the coals in order to aroid detection, and I had chosen Mrs. Buck- 
land's usual morning shopping-time to charge him with sawdust. Unfortunately I had miscalculated the time. It appears that she had not gone out, and that the savoury odour had ascended to the bedroom windows. As the vulture smells his prey from afar off, so did Mrs. B. discover that there was a stinking fish in the house. She therefore descended upon me and John with outstretched pinions and raised crest.

"It was too late to bolt, so I stood it out. Expostulations were in vain. She turned the empty bottles out of a hamper and put it under the fish. She then cut the rope with a kitchen-knife, and the fish fell with a flop into it. The hamper was then directed to Mr. Edon, at my museum. I am glad to say they had a job to get it upstairs, and I would not help. The last I saw of the hamper was that it was standing on the pavement outside the Parcels Delivery Office, not in the shop, and that a dog was sniffing inquiringly through the cracks in the hamper, and that there were several blue-bottles flying about over the vicinity."

In October, 1873, I received a very fine angler fish canght in a trawl in 27 fathoms of water, between Berry Head and Start Point, on the coast of Devon; this fish weighed 47lbs., and was 3ft. 11in. in length, and $1 \mathrm{ft}$. $6 \frac{1}{2} \mathrm{in}$. in the widest part. In its stomach I found two mary-soles, one common sole, one piked dog-fish $\mathbf{1 f t}$. 6 in. long, three moderate-sized crabs, fourteen fivefingers, and one whiting.

This fish is called the angler, or fishing-frog, on account of a most wonderful provision it has to attract other fish, by means of two long moveable spines connected with the top of the head. The mechanism by which this lure is worked by the fishing-frog is most interesting: it consists of a ring working within a ring. 
The reader would do well to dissect it out, and see how beautifully this contrivance works.

Acanthoperi.

\section{ATHERINE.}

German : Der Schrätzer.

Atherinida.

The Atherine, or Sand-smelt (Atherina presbyter), is a small handsome fish, from four to five inches long. It

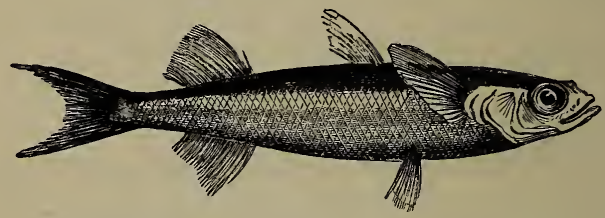

atHerine (Atherne boieri).

is very pretty in appearance; from the fine broad silver stripe along the side it looks attractive on the fish-stall. It is a common fish on the southern coasts; and at Brighton is considered a delicacy, and sold in large quantities to visitors during the winter months. As will be seen from the specimens in the Brighton Aquarium, this is a very graceful and pretty little fish.

I am informed by my secretary, Mr. Searle, that these atherines are very plentiful on the Hampshire coast, especially at Lymington, where they come into the river in the summer, and are caught by thousands in the fresh or brackish water. The method of taking them is in this way: a man from a boat drops a large round shallow net fastened by a rope to the end of a pole into the water to the bottom, and then strews crumbs of bread over it, and by leverage of the pole on the side of the boat sometimes brings up thousands at a time. They have the same cucumber scent, but not so strong, as. the sparlings and smelts sold in the London markets. 


\section{THE BARBEL.}

Abdominales Malacopterygii.

Cuprinida.

(Cyprinus barbus.)

German : Die Barve, Barm. French: Le Barbeau. Swedish: Barbfisk. Dutch: Barbeell. Italian : Barbolo.

THe Barbel may be said to be a water-pig, his habits in the water are so very like those of a pig on the land.

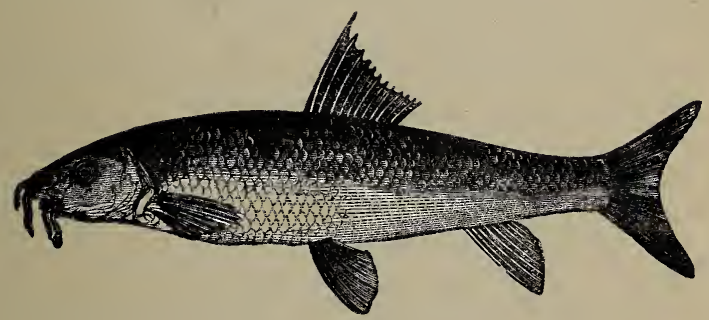

BARBEL.

His leathery mouth is most admirably formed for routing about, and he lives principally by feeding upon insects which live among the plants (I do not call them weeds) which cover the stones at the bottom of the water. The poet Hood has recorded the barbel's grubbing propensities in the following lines:

'In they went, and hunted about, Open-mouthed, like chub or trout, And some with upper lip thrust out,

Like that fish for routing-the barbel."

To the anglers of London and the towns on the Thames, as well as to the fishermen of Nottingham, Sheffield, \&c., the barbel is a very important fish, affording wonderful sport in the season. Barbel delight principally in the rapid water below weirs. $\mathrm{He}$ is also 
found in parts of the river where the water runs quickly, scours, and shallows. The barbel is not good food, nevertheless the Jews eat him during their holidays. The eggs of the barbel are said to be poisonous, and to produce the same symptoms as belladonna. Fishermen about Windsor have a horror of barbel's roe, so there must be something in the story.

When the weeds die off and the winter comes, the barbel, as it were, hybernates; he goes into deep holes, and there remains until the warm weather returns. I once discovered the winter haunt of these barbel at Old Windsor; a very large number of them lay perfectly quiet in a very deep hole under the roots of a willow tree. They seemed very torpid. I did not disturb them, nor did I tell anybody of their whereabouts. The head of the barbel makes a beautiful preparation when dried. Two heads should be dried, one with the pig-like lips shut, the other with the same expanded. It will be seen that he has four barbules at the end of his upper jaw, and two shorter attached to the orifice of the lips. The use of these, no doubt, is to enable the fish to find his food at the bottom of the deep holes where he lives, to which, I expect, very little daylight reaches. I expect the barbel is very nocturnal in his habits. Anglers for barbel tell me that the best sport at barbel catching is after dark, when the mills are stopped, and the barbel are hunting about in places where they could not probably get when the stream was running in full force.

When a barbel is hooked, he always endeavours to strike at the line with his tail, to break it. Now, if we examine the back fin of the barbel, we shall find that the first ray of it is cut out into deep notches, just like a saw. The use of this fin I imagine to be to steady 
and steer him in the rapid currents and mill-streams in which he lives. If we move the serrated ray upwards, we find the whole fin follows it, and is kept tense by it; let it go, and the fin again sinks down. In the mast of a London barge we find a parallel contrivance. The barge makes headway by means of this contrivance; so does the barbel, only that his sail (so to speak) is opposed to water, not wind.

Most fish that live in dark places have scales more or less brilliant. The barbel's scales are of a pale gold colour edged with black. They are very numerous, and this will be seen if a portion of the barbel's skin be taken off and dried on the window-pane. It 1s not everybody who can catch barbel. They are very artful, and require to be collected by means of ground-bait.

A good day's barbel fishing is enjoyable above all measure, but it is most advisable to employ a professional fisherman to ground-bait the "swim," arrange the tackle, \&c. The finer the tackle used for barbel the more sport you get in catching them. The bite of the barbel is a double knock, a "rat-tat." I myself like to use a Nottingham reel. The barbel when first caught has the power of making a very peculiar noise, which is one of the many problems which I wish my readers to investigate and, if possible, explain. If the finger be placed down the throat of a live barbel, it will be found that it will be nipped very smartly by a set of very large teeth in the pharynx. These should be taken out, and the flesh removed either by boiling or scraping, or both; it will then be seen they are rery strong and crooked, mounted in three rows. 


\section{A WORM FARM AT NOTTINGHAM.}

An enormous quantity of lob-worms are annually used by the barbel fishers of London and the Midland counties. The following is my report, published in Land and Water, No. 602, p. 88, August 4, 1877, of a visit I made to a worm farm at Nottingham, the proprietor of which is well known and respected by all the many anglers, especially barbel fishermen, who deal with him :-

"When at Nottingham a few days ago, on the Dynamite inquiry, I was much pleased at the discovery of, to me, an entirely new industry ; namely, the rearing and education of worms for the purposes of anglers. My friend Mr. Jardine first mentioned to me that Mr. Wells, fishing-tackle maker, of Sussex Street, Nottingham, carried on a business and trade in worms, and he advised me to call on him. Mr. Savage, of Nottingham, kindly accompanied me to Mr. Wells's shop, at which can be purchased excellent fishing-tackle of all sorts and kinds, especially that suited to Thames and trout bottom fishers. Mr. Wells also carries on the occupation of barber.

"Mr. Wells has several people in his employ who collect worms every favourable night during the year. He sells the following kinds of worms; viz., the lob or dew-worm, the cockspur, and the ring-tailed brandling. In dry weather worms are very scarce; the men liave to water the ground for them. In wet weather the worms are better and heavier. They are caught in the meadows and pasture lands in the neighbourhood. The worm supply is not falling off. Mr. Wells complains they are building over many of the waste lands, and thus 
diminishing his hunting-ground for worms. Mr. Savage says it is a very interesting sight to see the lights of the numerous wormers when they are out with their lanterns collecting of a dark night. Unless it was known what these people were doing, it would be impossible to guess the cause of this Will-o'-the-Wisp catcher phenomenon. Men, women, and children are employed in 'worming.'

"The worms are sold by the thousand or the quart. In a warm, moist night, from two to six thousand worms are brought in by the collectors. Some people can collect worms much better than others. The worms are very cunning, and are apt to pop back into their holes if the person treads heavily.

" 'You, sir,' said Mr. Wells to a gentleman who formed one of our party, 'you would make a capital worm-catcher.' You should have seen my friend's face! (He is a very tall man, and did not quite see why he, of all the company, would make a good worm-catcher.) 'Why would this gentleman make a good wormcatcher?' I asked, immediately. Says Wells, 'You see, sir, the gentleman is so long on his pins, and has a great reach with his arm, so that he couid stand still in one place and catch the worms all round him without moving about much. A short gentleman, like you, sir (pointing to me), would never make a worm-catcher; you haven't got reach enough in the arm, and you're too short in the leg. The worms are terrible artful things. This gentleman I'd back to catch worms against you any night, and I give you a thousand worms in to start with.'

"When the worms are brought in, Mr. Wells at once begins his training operations by placing them in properly selected moss. Stag's-horn moss will not do at all, it is too harsh. Grass is bad. Field moss is the 
best. The worms are put into the moss to scour. The way to test a worm is to take him up and pass the finger gently down the length of him. If anything comes out of him he is not fit, and is put back for further training. The meaning of this is, that the wild worms contain, more or less, food undergoing digestion. When put into the moss this food disappears. The moss in some way facilitates this operation, but I cannot quite see how this is, unless the worms disgorge all their former food, and practically become very little else than slin.

"The keeping of worms depends very much upon the weather. They will not keep well above a week. Mr. Wells has a supply of worms ready for his customers all the year round. He goes over his moss very frequently, picking out the 'mauled and mashed' worms, and only sending to market the 'plump and healthy' ones.

"He showed me the handsomest worm he had on hand. It was a 'maiden dew-worm.' The peculiarity of this lovely maiden is that it had a very square tail, a small head, a long body, and no joints in the middle. This was the best-looking worm out of fourteen or fifteen thousand that were in the cellar, undergoing a course of education.

"The worms are packed up for market in moss; the bags used are of light canvas.

"The demand for worms is very great, and he sends great numbers to London. In Nottingham alone there are fifty-two angling societies, and 1,700 members. The interests of these anglers are ably looked after by $\mathrm{Mr}$. Savage. The business of worm-selling has been going on some ten years, and is gradually increasing. The norms are not counted out, but are guessed at. $\mathrm{Mr}$. 
Wells gives good measure. A member of the Piscatorial Society told me that he once counted out one of Wells's 'thousand worm bags.' He found he had 300 worms over. Nottingham worms are well known in all angling localities. Last year he sent to London alone the large number of 400,000 worms. The price varies much. They average 3s. $6 \mathrm{~d}$. per 1,000 . The worms are principally used for barbel fishing.

"Not only does Mr. Wells collect worms, but he also breeds them in considerable quantities. In his garden is a special heap made of vegetable matter, expressly for the purpose of breeding worms. I shall not, of course, say what substance for worm-breeding is most favourable: this is a professional secret. On turning the heap over where the worms are bred, it was very interesting to see the worms in various stages of growth. $\mathrm{Mr}$. Wells knows from experience pretty well what the age of a worm is. I had the pleasure of pointing out to him the eggs of the worm. These are about three lines long, and somewhat oval. They have a sort of lid at each end, which opens when the young are liberated. I believe that two young are sometimes produced from the same egg.

"I think my readers will agree with me that Mr. Wells's business in his worm farm is quite unique. I wish him every success, and the patronage of all anglers." 


\section{BLEAK.}

Abdominales Malacopterygii.

Cyprinida.

(Alburnus lucidus. Lenciscus alburnus. Cyprinus alburnus.)

Local names: Blick, Bleik, Bleis, Blaze, Willow Blade. French:

L'Ablette. German: Weissfisch, Albe Marienfisch. Welsh:

Coìwyniad. Danish: Lojer. Swedish: Loja. Italian: Avola.

A vERY elegant and useful little fish of great activity. He frequents the fastest streams, swimming gracefully

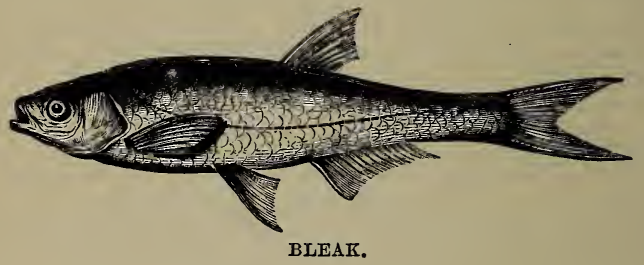

on the surface of the water. This pretty little fish is particularly active in sunny weather; he is a great eater of flies, and almost anything, animal or vegetable. that comes down with the stream.

A good way to catch him is with a fine hair line and small hook, baited with a common fly, piece of fat bacon, or a very small artificial gnat. Bleak are very common at the mouths of sewers, and when inspecting the Severn at Shrewsbury, I went to the mouth of a sewer to see what effect it was having on the river. The water was ink-black from the waste dye from a manufactory, and was so warm that steam was seen on the surface of the water. The bleak were here in vast shoals feeding on the midges hatched out by the warm water. It was satisfactory to find from the presence of the bleals that this particular pollution could not be very injurious to salmon life. 
Immense numbers of bleak ean be seen at Oxford, at the point where the town sewer joins the Thames near Folly Bridge. This terrible stream goes by the appropriate name of "Pactolus." These little fishes do an immense amount of unpaid labour. I am surprised that the Oxford authorities allow the Thames to be polluted to the detriment of the health of the town's people and members of the University.

I have long known that bleak scales were largely used in the manufacture of pearls, but had the greatest difficulty in getting any satisfactory particulars about this curious manufacture in which the ladies are so much interested. My friend $\mathrm{Mr}$. Sachs, jeweller, of 22, Hyde Park Place, Marble Arch, with his usual kindness, took a great deal of trouble in the matter, and after due investigation he sent this valuable and interesfing article, which I published in Land and Water, August 10,1878 , No. 655 .

\section{ARTIFICIAL PEARLS-HOW MADE FROM THE SCALES OF BLEAK.}

In a previous number of Land and Water, Mr. Frank Buckland asked some kind friend to instruct him in the art of making imitation pearls. I beg to inform him that in the Exhibition held in Hyde Park in 1862 a Frenchman made an excellent display of such wares, also bottles containing liquid fish scales, glass beads, \&c., showing the whole process of manufacture; he very artfully placed a row of large real and imitation pearls alternately, and without close inspection it would not have been possible for a judge to have selected the real from the unreal. I herewith send some Romanmade pearls and some of the modern French, which latter you will see are very fine. The old Roman pearls 
consist of white wax beads covered with nacre, or pearly lustre. The cheap French pearls are glass balls filled with white wax; the better and patented sort are opa. lescent glass beads filled with gum mastic, these being the finest imitation of the Oriental pearl, almost as heavy, and always look and wear the same. Not so the Roman wax pearls; they in time lose their nacre, and in a heated room are apt to stick to the skin.

As it will no doubt interest your readers, the ladies in particular, to learn how these mock pearls are manufactured, I give the following translation from Dieulafait's book on diamonds, pearls, and precious stones, 1874:

"False pearls are little hollow spheres of glass covered internally with a coating imitating the orient of natural pearls. Their fabrication comprehends two series of operations-the production of the sphere, and the introduction of the coating. The spheres are produced by the glass-blower, who, by aid of an enameller's lamp, solders the extremity of a tube having the proper diameter, and blows into the tube when the substance is of the right consistency. In this way very regular little spheres are obtained, that serve for the composition of the ordinary quality of false pearls.

"In pearls of great beauty the tube employed is slightly opalescent, and the glass-blower, besides, gives to the little spheres, while they are yet malleable, certain slight perceptible inequalities of surface, by gently tapping them with a small iron bar. This gives them a yet greater resemblance to natural pearls, which are very seldom absolutely regular.

"No mention is made in ancient writers of artificial pearls being made, and it is not till we come down to the beginning of the sixteenth century that we find 
Venice had then established a reputation for this branch of industry.

"At first the glass balls were filled with various materials, generally with a base of mercury. But in the year 1680 a rosary maker, named Jacquin, conceived the idea of using, in the place of this mercurial mixture, a harmless substance that produced an infinitely more perfect colour.

"This substance, the essence of orient, is formed from the scales of the bleak, or ablette, a little white fish which abounds in the Seine, the Marne, and the Loiret.

"The fishes are rubbed rather roughly in pure water contained in a large basin; the whole is then strained through a linen cloth, and left for several days to settle, when the water is drawn off. The sediment forms the essence of orient. It requires from 17,000 to 18,000 fish to obtain about a pound of this substance.

"The scaly substance is liable to decompose quickly, and numerous chemical agents are employed by different manufacturers to preserve it. These means are liept a secret, but it is known that liquid ammonia, or the volatile alkali, is one of the substances most commonly used.

"The process of colouring the pearl is commenced by lining the interior of the ball with a delicate layer of perfectly limpid and colourless parchment glue, and before it is quite dry the essence of orient is introduced by means of a slender glass blow-pipe. It is then allowed to dry; the pearl is filled with wax, and, if intended for a necklace, is pierced through the wax with a red-hot needle."

From a German book on precious stones, \&c., by Kluge (1860), I translate the following: 
"The art of making imitation pearls is ascribed to one Jacquin, a chaplet and rosary manufacturer at Passy, 1680. Noticing the water after cleaning some white fish (Leuciscus alburnus), a species of dace, was of a silvery appearance, he gradually collected the sediment, and with this substance (to which he gave the name of essence d'orient), and with a thin glue made of parchment, he lined the glass beads, and afterwards filled them with wax. The method of making the round bead is by heating one end of a glass tube and blowing into it two or three times, which then expands into a globular form. The workman then separates the bead, places the end which has been heated on a wire, and heats the other end. This process is called bordering or edging. The best pearls are made in the same way, the holes of the tubes being gradually reduced by heat to the size of those of the real pearls, the workman taking each bead on an inserted wire, and, by continually turning them round in the flame of the lamp used, they become so true as to be strung as evenly as the Oriental pearls. The lamp used is similar to a glassblower's foot-bellows apparatus, and the work is always done by lamplight, daylight being unsuitable. Seven pounds' weight of fish scales give one pound of essence d'orient."

Some fifty years since the French were large purchasers of bleak scales from our Thames fishermen; they now supply themselves from their own rivers. The value of their export is over 1,000,000 francs annually, besides the fabulous quantity used in France. 


\section{THE BLENNIES.}

Acanthopteri.

Blenniida

Blennies are frequently found left by the retiring tide in small pools on the rocky parts of the coast, and are active and vigilant, hiding themselves in small crevices or under seaweed, and remaining concealed till the return of the tide.

Blennies possess a curious faculty, which was formerly attributed solely to the chameleon, the power of moving their eyes either in unison or independent of each other: thus, they are seen glancing in one direction with one eye, while the other remains motionless, or is turned towards a different point. Blennies, wrasses, suckers, possess this peculiarity in the powers of vision.

The Shanny, or Smooth Blenny (German : Die Meerlerche; French: La Blennie pholis) rarely exceeds five inches in length, and is easily distinguished from its congeners by having no tentacles on the head. It is very active and vivacious, and by help of its ventral fins creeps up the rocks with great facility. It will live for many hours out of water, and is such an adept at

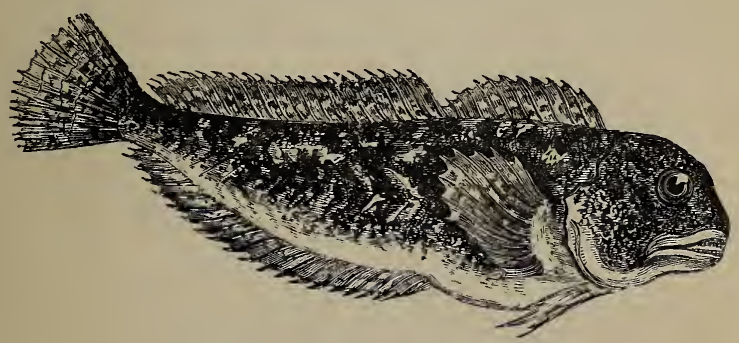

THE ShaNNY, OR SArooth BLENNy (Blennius pholis).

concealing itself, that though so very common, specimens are procured with difficulty. It takes up its 
residence under a rock or stone, whence it rarely wanders far. Like others of the genus, it varies much in colour according to the ground it occupies.

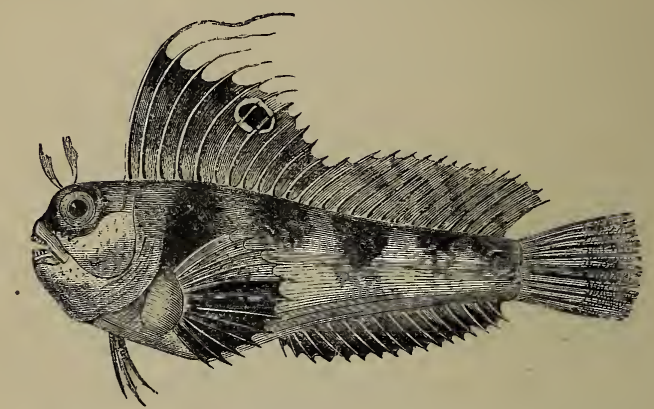

BUTTERFLY FISF.

The other species are Montagu's Blenny; the Ocellated Blenny; the Butterfly Fish, so called from the singular appearance of its spotted dorsal fin; the Gattoruginous Blenny, not uncommon in Cornwall, where it is taken in crab-pots, and called by the Cornish urchins "Tompot;" and the Crested Blenny, which has on the head a small crest, which the fish can erect and depress at pleasure.

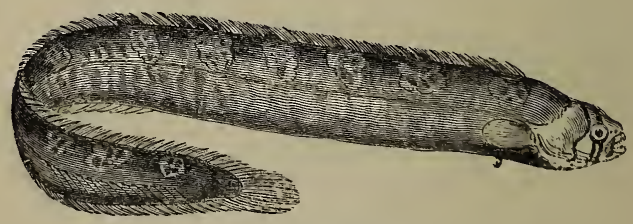

BUTTER GUNNEL (Blennius gunellus).

The Spotted Gunnel (German: Der Butterfisch), also called the Butter-fish-from the slimy secretion which covers its sides-is a common small fish on our coast, of similar habits to those already described. 
Visitors to the seaside are nearly sure to find specimens of this fish among the rocks, and if they try to catch it they will immediately learn why it is called the "butter-fish."

The Viviparous Blenny (German: Die Aalmutter, or Aalquappe) brings forth its young alive. These seem perfectly able to provide for themselves the moment they are

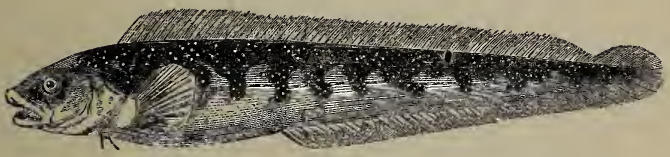

VIVIPARous BLENNX (Blennius Zoarces).

produced. These little creatures, when rery young and transparent, form excellent objects for the microscope, for viewing the circulation of the blood. The length of this species is from ten to twelre inches. Its habits resemble those of the other members of the family, and it is found on various parts of our coast, especially on the northern and eastern shores.

I have a fine specimen of a mother (viviparous blenny) and young in my museum. By the side of this specimen is a most interesting specimen of a viviparous fish (Ditrema argenteum) from British Columbia. In this case the young fish are seen in situ, not jet born, packed closely together like the quarters in an orange. It was presented to me by J. R. Lord, Esq. It is described in his work, "The Naturalist in British Columbia."

Besides these another British blenny is the Yarrell's Blenny. 
Acanthopteri.

\section{THE BERGYLT.}

The Bergylt (Sebastes Norwegicus, Perca marina, Lacepede), or Norway Haddock. This fish is much like a large perch, of a blood-red colour. They are believed to live together in considerable numbers on stony ground at the enormous depth of from one hundred to one hundred and fifty fathoms. Mr. Couch states: "The young are produced in June, and it is supposed from good evidence that they proceed from the mother alive, and it is confidently believed by the fishermen that they continue to accompany the mother for some considerable time."

In May, 1867, Mr. Grove, of Charing Cross, kindly forwarded me some specimens of the bergylt. A box of these fish had been offered for sale in Billingsgate market, but no one knew anything about them, or from whence they were brought.

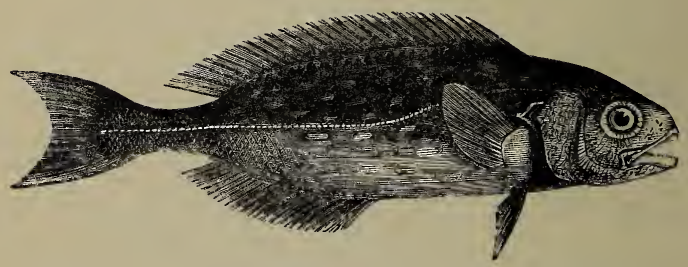

BLACK FISI.

The Black Fish (Centrolophus pompilus), an inhabitant of the Mediterranean, has been only four or five times seen on our coast. The colour is wholly black-the fins intensely so, the abdomen being somewhat lighter.

Mr. Matthias Dunn, of Mevagissey, Cornwall, thus writes in Land and Water, June 29, 1872, respecting this fish: "A black fish was landed here this morning; 
length 12in., depth 3 in. This example differed a little from the specimen plate given by $\mathrm{Mr}$. Couch in his 'History of Fishes,' the sides of this fish being slightly spotted with white, clearly to be seen when fresh. This is the fourth fish of this kind known to have been $\checkmark$ taken here, and all in mackerel nets. In each instance they seemed to be acting the part of pilot fishes to some variety of shark, and which had been entangled in the net close by it. The above-mentioned specimen was caught near a porbeagle shark."

My friend Dr. Francis Day, late Inspector of Fisheries for India, has kindly sent me the following note: "The Centrolophus pompilus, or Black Fish, has a very curious history, which I worked out some months since, but have not yet published." The first British specimen was recorded by Jago: it was taken May 26, 1721, on the Cornish coast. In 1830-31 Couch re-discovered the fish. I have records of about ten others taken in Great Britain. I was given a specimen at the Berlin International Fishery Exhibition which came from the Mediterranean.

Acanthopteri.

\section{BULLHEAD.}

(Cottus gobio.)

Sclerogenida.

Local names: Miller's Thumb, Bullhead, River Bullhead, Tommy Logge, Tom Culls. French: Chabot commune. German: Der Kaulkopf, Die Muhlkoppe, Rotzkolbe, Groeppe, Gruppe, Koppe, Der Kautzenkopf.

THis little fish is found in rivulets and brooks about old timber bridges, where they look like mice running up and down close to the woodwork. He has an enormous head and mouth and a very sharp-pointed body. On each side of his head there is a very sharp needle-pointed 
spine. The iris of the eye is very brilliant, reminding us of a toad's eye. The bullhead may be said to be the chameleon among fishes; it is very rare to meet many of the same colour. The colours they assume are yellow, brown, orange, emerald green, \&c. Nobody knows when or how they spawn.

They are very common in the Itchen, in Hampshire. I was educated at Winchester College, and one of the great sports of myself and other boys was to "spear Tom Culls." Our mode of proceeding was to fasten an ordinary. dinner fork on the end of a stick, and "spear the Tom Culls" as they lay among the stones. This required great dexterity, as the fish was very slippery, and the fork, not being barbed, was a difficult instrument to catch them with. Tom Culls are said to be great enemies to trout eggs, and they would doubtless eat the fry out of the gravel if they had the chance

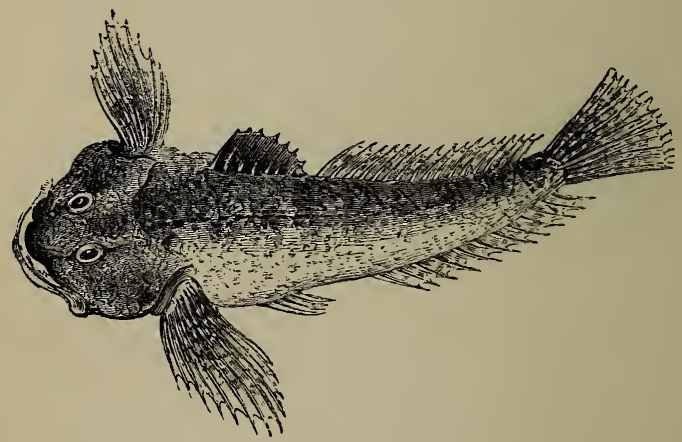

RIVER BULLHEAD.

By the kindness of Lord Radnor, Longford Castle, Salisbury, I received in April, 1880, a grebe (Podicels minor), choked by a bullhead. The fish was fixed so firmly in the bird's mouth that I found it would go 
neither backwards nor forward, so I could neither press it down the œsophagus nor pull it out altogether. $\mathrm{Mr}$. Grebe evidently was not aware that the Miller's Thumb was armed with two very sharp spikes on each side of the gill cover, and when the fish found himself in trouble he simply expanded these spines, which fixed him so firmly in the bird's mouth that he died from suffocation. I have had two or three specimens sent me of kingfishers destroyed by bullheads sticking in their throats.

Acanthopteri.

\section{SEA BULLHEAD.}

\section{(Cottus scorpius.)}

Sclerogenida.

Local names: Sea scorpions, Sea devils, Sea toads, and Fatherlashers. German:Der Seeskorpion. Danish: Ulk. Swedish: Skraba. French: La Cotte scorpion.

The Father-Lasher, Sting-Fish, or Long-Spined Cottus, is a very common fish among the rocks upon the British coast, and is very fiequently found left in fishing weirs when the tide goes down. It is often caught in shrimp nets, for its principal food consists of shrimps. Its head and cheeks are armed with spines. The Folkestone fishermen call it the bull-rout. - When taken out of the water, it always distends its gills as wide as it possibly can; the spines on the gill covers are formidable weapons. A man who was fishing with a shrimp-net caught a Father-lasher, and without thinking, tried to bite its head off; the fish gave a sudden kick and slipped down his throat; it then expanded its gills, the spines stuck in the man's throat, and he was shortly suffocated. 
Aspidopherus (Cottus).

\section{THE POGGE.}

German: Der Steinpicker. French: Aspidophore.

This fish is also called the Armed Bullhead, the Hardhead, or Hook-nose. He has two sharp curved hooks at the tip of his snout and the rising generation of

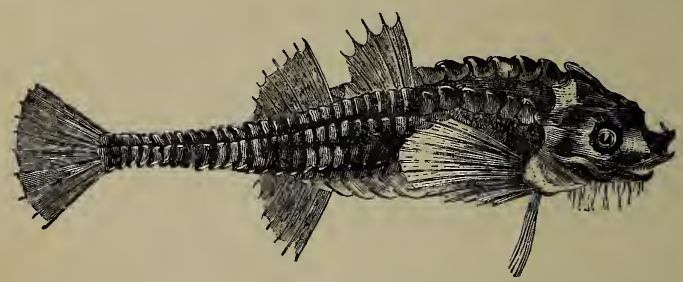

THE POGGE, OR HOOK-NOSE (Aspidophorus Europaus).

shrimpers hook the Hard-head on the tip of their noses, and then chuck them with a jerk backwards over their heads; here then is a new game for London juveniles at the seaside. The shrimp fishermen will readily "save" some Hook-noses if asked so to do.

Acanthopteri.

\section{SEA BREAMS.}

The Sea-Breams (Sparida) somewhat resemble the perches, the body being generally of an ovate form, and covered with large scales. The chief kinds are the old Wife, or Black Sea-Bream (Sparus cantharus), the Bogue (Boops primus), the Becker, Couch's Sea-Bream (Pagrus orphus of Cuvier, Erythrinus), Common Sea-Bream (Sparus auratus), Spanish Bream (Pagellus erythrinus), Auxiliary Bream (Pagellus acarne), Sparus or Dentex (Dentex vulgaris), Black Sea-Bream (Pagrus lineatus). 
The Sparus auratus is the most common in British waters. It is the most brilliant of the breams, and it is readily distinguished by a large dark spot on the shoulder. Its colour is flesh-red, with golden yellow reflections; the

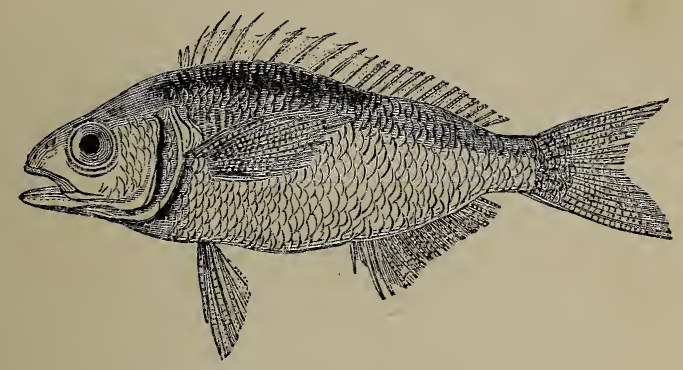

SEA-BREAM (Sparus centrodontus).

usual size is from sixteen to twenty inches. It is most abundant in summer, when the young approach the shore in multitudes, and, as they readily seize a bait, they are taken by anglers from the rocks. In the immature state they are called "chads," and are without the dark spot on the side.

The Bogue (Box boops) is a very rare British fish. In August, 1870, I received a specimen from Mr. Matthias Dunn, of Mevagissey, Cornwall. It was taken to the eastward of Chavays Castle, whither it had probably wandered from the Mediterranean. Mr. Dunn writes: "Our oldest fisherman never saw a specimen like it before." This specimen measured eleven inches, and was of a most brilliant colour. It is now in my museum.

The Braize, or Becker, or King of the Sea-Bream, is of a beautiful red colour, and is said by Mr. Couch to be not uncommon on the Cornish coasts in summer and 
autumn, though it is never abundant, and the young are rarely seen.

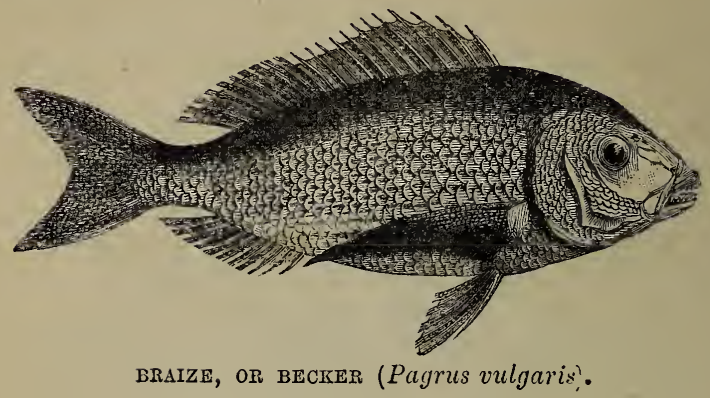

\section{THE GILTHEAD.}

IN hunting over my Museum of Economic Fish Culture, South Kensington, for what I thought might be acceptable at the Berlin Exhibition, I came across two very beautiful jaws of fish, one of which I now figure. They were given me in 1871 by my late friend Mr. Frederick Lee, the well-known Royal Academician, who kindly brought them from South Africa in his yacht the Kingfisher. These teeth are those of the gilthead bream (Chrysophrys aurata). They are very large specimens, considerably larger than any in the College of Surgeons.

Mr. Lee informed me that the fish to which the jaw figured belonged weighed between $501 \mathrm{lbs}$. and $601 \mathrm{lbs}$.

The gilthead is found in the Mediterranean, and from Gibraltar as far south as the Cape. They live, I believe, in the surf among rocks and in very rough water. They feed upon very hard and thick shells, such as are found on rocky and storm-washed foreshores.

Could any set of teeth be possibly better adapted to the grinding up hard shells than those the representa- 
tion of which is now given to the reader? The two foremost teeth, it will be observed, are adapted for nipping purposes, and by means of these he is enabled

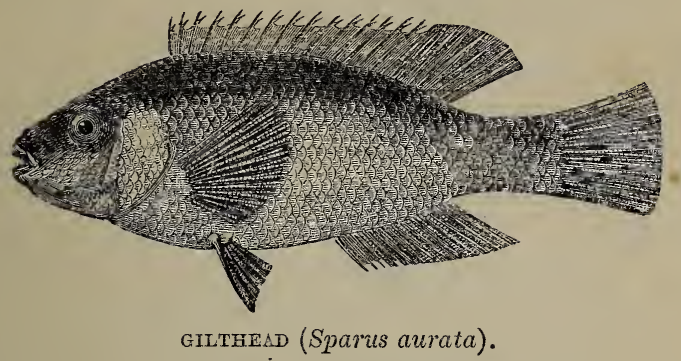

either to tear off from, or else crack when still adherent to the rocks, the hard shells upon which he subsists. In order that these shells should be triturated and ground up, we find at the posterior portion of the jaw four stud-like

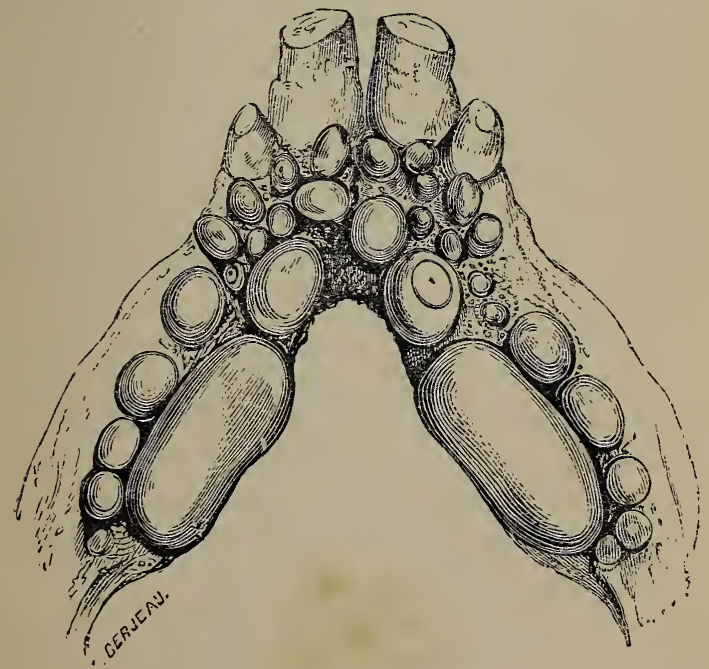

TEETH OF THE GILTHEAD. 
teeth; the largest are much the shape and size of an ordinary broad bean. These, it must be acknowledged, are admirably adapted for the grinding up of hard substances, and although $I$ do not know it for a fact, yet I should consider it more than probable that the gilthead bream would prey upon corals such as are found at the Cape of Good Hope.

The reader should examine for himself the teeth of the common sea-bream, which are also evidently constituted for crushing purposes; they are not of quite such a handsome pattern as those of the gilthead bream. We find a somewhat similar arrangement in the teeth of the common cat or wolf fish, a fish not unfrequently caught by the North Sea trawlers, and exhibited in the London fishmongers' shops.

This wolf fish lives in the vicinity of wrecks, and probably tears up the decomposing timbers to get at the boring worms which live in it. Without doubt, the wolf fish lives principally upon whelks, and the whelks are found in the stomachs of the fish in a comminuted state, showing what great power the teeth have in cracking them up.

The study of the structure of the teeth of recent fishes is of the greatest service in getting some idea of the habits of the fossil fishes.

Our readers who may happen to live in the oolite formation may possibly have had brought to their notice specimens of what the quarrymen call Bufonites, or toad-stones.

Now, these toad-stones are in reality the teeth of the fossil fish Acrodus nobilis, figured by my father in his. "Bridgewater Treatises."

In his lectures at Oxford the Dean used frequently, especially when speaking of Stonesfield, near Blenheim, 
in Oxfordshire, to give his class a word-picture of the conditions of things which (according to the evidence given by the fossil remains of shells, corals, saurians, and fishes) must necessarily have obtained at the bottom of the ancient seas when our world was but a chaos. He has put this idea into the following words, when speaking of the form and structure of the teeth of recent fish as compared with those of their fossil ancestors :-_"We thus introduce an additional element into geological calculation. We bring an engine of great power, hitherto unapplied, to bear on the field of our inquiry, and seem almost to add a new sense to our powers of geological perception."

Apropos to the teeth of fish in general, and especially those of the Bream, I wrote in Land and Water, June 19, 1880, as follows:

"It is among the teeth of animals that we find examples of the most beautiful mechanical designs, whether for tearing, crushing, grinding, \&c., a subject so eloquently elucidated by the greatest of modern anatomists, Professor Owen. In fact, so wondrous is the variety of teeth, and so excellent is their adaptation to the work they have to perform, that I think it must puzzle the followers of Darwin's doctrines to account for their beauty of structure as well as the ease and smoothness of their action.

"Among fishes more especially is the structure of the teeth most noticeable. In fact, hardly any fish can be examined without our finding that he carries an armament of teeth either in his jaws or else in his gullet, the structure and working of which are most worthy of the attention of all who are willing to believe what they see, and, above all, recognize creative design in the most humble of beings." 


\section{"BRAMA RAII," OR RAY'S BREAM.}

Acanthopteri.

Chalodontida.

German: Der Meerbrassen. French: Castagnole. Swedish : Rödjisk.

"Brama RaII," or Ray's Bream (Spare castagnole). In September, 1868, the Duke of Northumberland sent me, from Alnwick Castle, a splendid specimen of this fish,

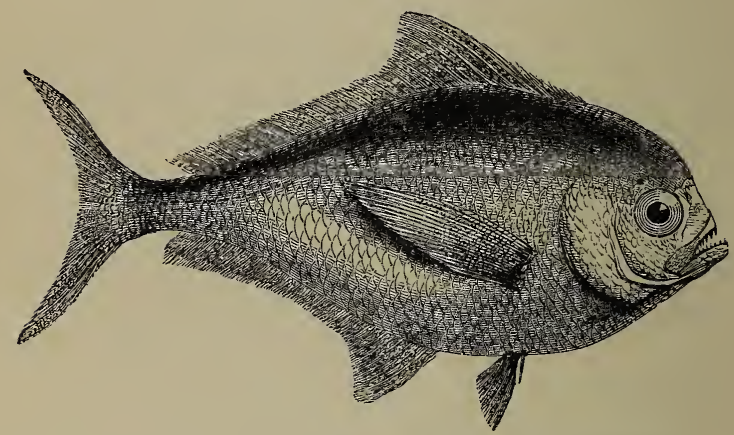

'BRAMTA RAII," OR RAY'S BREAMI (Spare castagnole).

weighing $4 \frac{1}{2} l b s$. ; it was $16 \frac{3}{4}$ inches long, and $8 \frac{1}{2}$ inches in depth. Couch figures it under the name Brama Raii (Spare castagnole), and says: "It is worthy of notice that a large proportion of these fish, have only been met with dead on the shore after a storm, or ready to expire, as if they had been exposed to some uncongenial influence of weather or temperature."

I notice that beneath each pectoral fin there is, as it were, a secondary small fin. The tail is deeply cleft. All the rays of both dorsal, abdominal. and caudal fins are armed at their posterior aspect with a row (on each side) of scales. These lie one upon the other like the scales on the shoulder-straps of a Life Guard's cuirass, 
or exactly like the horn-like gatherings on the edges of the feet of the capercailzie. In a fresh state they are resplendent with silvering. Remains of this colouring can be seen in a semi-dry state. The teeth are conical, and very sharp-pointed.

Abdominales Malacopterygii.

\section{BREAM.}

(Cyprinida cyprinus, or Abramis brama.)

Local names: Carp-Bream, Yellow Bream, Lake Bream. French. La Brème. German: Brachsen or Blei. Polish : Krainisch. Dutch : Blei

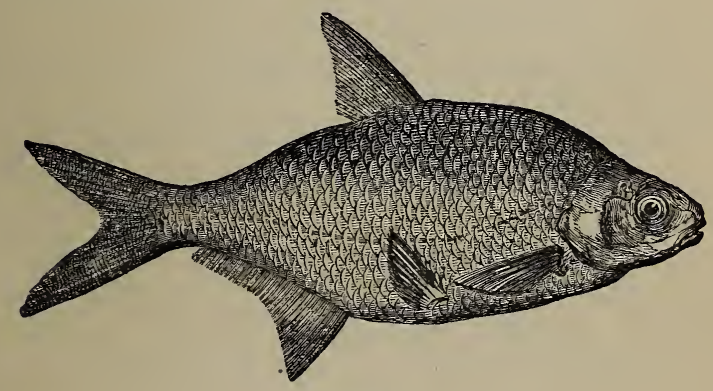

BREAM.

Mr friend Dr. Norman, of Yarmouth, has written the following capital account of an angler of the village adjoining the Norfolk Broads (where these fish abound) fish. ing for Bream : "The first thing the fisherman looks for is the worms. They must be worms of the largest size, not those dug out of the ground. They must be picked up off the grass at night. The hole he fishes in is as deep, to use his own words, as two pair of reins and a plough-line. His ground-bait is made thus: he gets half a pailful of bullock's blood, a pailful of fresh grains, half a pailful of very clean clay, a handful of 
dog's greaves well broken up, three handfuls of meal, and a little oil-cake. This is all well worked up into a pudding, and worked into balls not quite so large as a child's head, and partially baked in the sun. He proceeds to his hole at daybreak, say three o'clock in the morning, and fishes with the roughest possible tackle. Sometimes these louts will catch nearly a hundredweight of bream in one morning before breakfast. This then is a good hint for any of our friends who propose to try bream-fishing in Norfolk."

Dr. Norman also informs me that great quantities of bream are taken in the spring months, especially about April, and sent away for crab and lobster bait. The fishermen use nets with a very large mesh, allowing all but good-sized fish to pass through. Bream in Norfolk were formerly of no value, now they fetch half a crown a bushel; large roach and rudd fetch the same price, and even more during Lent and the Hebrew Passover, when there is a great demand for these fish at Birmingham, Manchester, and other large inland towns.

When at Norwich in August, 1869, my friend Dr. Norman took me to the shop of Mr. T. E. Gunn, taxidermist, Upper St. Giles' Street, to see a bream which weighed $11 \frac{3}{4} l b s$. and measured $2 \mathrm{ft}$. $2 \mathrm{in}$. in length from the nose to the fork of the tail. It was over $10 \mathrm{in}$. in depth. This fish was caught in a pond about half an acre in extent at Beeston Regis, near King's Lynn.

It is most interesting that the age of this fish is known. A gentleman who called upon Mr. Gunn stated that he put it into this pond when very small about fifty years before. This is, I believe, the largest bream on record. Besides the Common Bream there are two other species, viz., the White Bream or Bream Flat (Cyprinus blicca), and the Pomeranian Bream. 
Anacanthini.

\section{BURBOLT.}

\section{(Lota vulgaris. Gadus lota.)}

Gadida.

Local names: Blob-kite, Burbolt, Cony-fish, Eel-pout. French :

Lotte. German: Quappaal, Aalquappe. Polish: Mietuz.

Danish : Kvabbe. Italian: Botatrice.

In this country the Burbolt is local, being not uncommon in the Trent, especially about Nottingham and Gainsborough, and Cambridgeshire. It is found in the rivers of Yorkshire, Durham, Norfolk, Lincolnshire, and Cambridgeshire, and the Swale in Yorkshire.

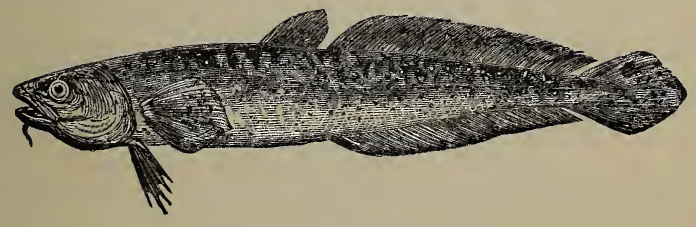

BURBOLT.

We Londoners very seldom see or hear of a burbolt, and they are such a stupid and ugly fish that I cannot advise trouble to be taken with their dissemination, though doubtless they would thrive in many of our ponds and lakes.

Burbolt are very numerous in the Lake of Neuchâtel. They are a nocturnal fish, in the day hiding themselves under the stones or in the mud. They do not seem to have many enemies, as they are never found in the stomachs of carnivorous fish. They spawn in the deepest holes in the lake-480 to 540 feet. Their spawning time is from the end of January to the beginning of March. During their spawning time the fishermen are allowed by law to fish for them and catch 
them by means of apparatus called berfoux. The reason why this is allowed is because the burbolts are so very destructive to the eggs of all other fish in the lake, especially perch. Burbolt stand frost well, and after having been frozen quite stiff will revive. They eat an enormous quantity of fry; they swim after the fashion of eels. They leave the lake for the rivers at night. About ten o'clock they ascend the rivers, and return again about two o'clock. This has been observed by the fishermen. No explanation of the fact is known. Night-lines are laid for burbolts in the lake ; trammelnets are also used for them, especially at the time when they are feeding on young perch. The flesh is said to be good, especially the liver when fried, but it is indigestible.

Abdominales Malacopterygii. CARP. cyprinida. (Cyprinus carpio.)

Local names : Common Carp, Seizling. German: Der Karpfen. French: La Carpe. Danish: Karpe. Swedish: Karp. Dutch: De Karper. Italian: Carpa.

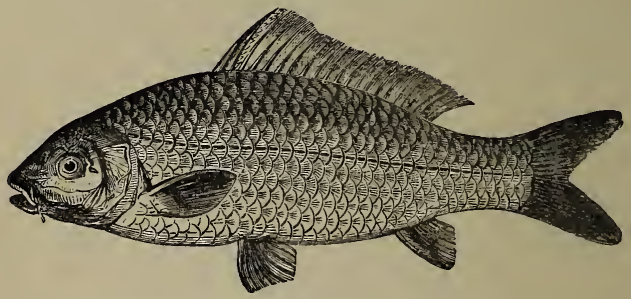

CARP,

IN examining a series of the casts of fish it is impossible not to be immediately struck by the architecture, as it were, of each fish. It is so admirably designed by 
the Creator, that each fish is perfectly adapted (it does not adapt itself, mind) to the conditions of life under which it has to live; an excellent illustration of this is the comparison of the salmon with the carp.

A salmon is built to live in very rapid waters, the carp to live in stagnant waters. The shape of the salmon may be said to be like that of a racing yacht, while that of a carp may be likened to a Dutch eelscoot. Carp may be said to be water-sheep-herbivorousgregarious-of a contented mind.

The carp is, probably, the most widely distributed fish of all the British species. In former times he was of great value as food, and hardly the ruins of a monastery in existence remain where the remains of the old carp pond, or stews, cannot be easily made out. In the days of the monks there were no railways, deep-sea trawling was not invented, and I doubt much whether mackerel drift-nets had come into use; even if they had, the transport of fish from the sea-coast would not have done for the monks, as fish could not arrive in an edible condition by means of pack-horses. That the monks were in the habit of eating the salted herring was very probable. Necessitas ingenii inventor. The monks, therefore, established carp ponds, where they could get a fish at any moment, either for a feast or a fast day. No doubt the monks had some excellent receipts for cooking carp. They should never be cooked when first taken out of a pond, but be placed in a box in running water, if possible; they will then get rid somewhat of their muddy flavour. The muddy flavour is probably produced from the food of the carp, which consists of young shoots of water-plants, insects, and worms which live in the pond.

There are generally carp of some size or kind in most 
ponds and lakes connected with country houses, and it will be well worth the while of proprietors to have the water drawn off to see of what their stock may consist; and this because it appears that after a certain number of carp are in a pond they will not multiply at all. In fact, by a wonderful law of nature, the crop of carp equalises itself by the quantity of food the pond will produce. Moreover, I am quite certain that after a time the carp will eat their own eggs, and very probably their young.

A remarkable fact about carp is that, according to my observations, the female sometimes carries two, if not three, successive layers of eggs. I confess I do not quite understand the physiology of this. Carp eggs are excessively numerous. I have a fine cast in my museum of a carp, kindly lent by Mr. Charles, of 2, Arabella Row, Pimlico. This fish weighed $21 \frac{1}{2}$ lbs. I have since, by carefully weighing the roe, discovered by average that it contained no less than $1,310,750$ eggs. Another smaller fish, which turned the scale at $16 \frac{1}{2} \mathrm{lbs}$., contained roe which weighed $5 \frac{1}{2} \mathrm{lbs}$., giving the total of 2,059,750 eggs. To be accurate, the weights and calculations were made by my friend the late $\mathrm{Mr}$. Thomas, a professional accountant.

Carp live to a very great age. Wheeler, who preceded Keene, fisherman at Windsor Park, told me that a carp in a certain stew in the park must be nearly a hundred years old.

At Fontainbleau, I understand that carp are shown with a white growth about their heads and bodies, and this is pointed out as a proof of their very great age. The fact is, that this white growth, sometimes called moss, is a parasitic vegetable fungus (Saprolegnia ferax). They are also subject to another disease, called the small-pox 
Not very long since, the carp in a certain pond at Windsor were attacked by some mysterious disease which killed many of them, and magnificent fish they were. I fancy I found out the cause, and suggested a remedy, which was immediately to remove the dead and dying fish, having put a grating over the sluice-gates, turning on a current of water so as to completely change the poisonous atmosphere in which the carp had to live. I also suggested that for the future only one-half the number of carp should be kept in the pond, the disease being, as in many other cases, caused by over-stocking.

I will now give a hint which, I trust, will not be thrown away on owners of country houses, and who have fishponds attached to their domains. In most of these fishponds are many carp which have never been angled for, and about which you will probably get no information from the gamelzeepers, gardeners, or other persons. I was staying once in a country house in Hampshire, to which was attached a very carpy-looking pond. The master of the house chaffed me about the fish in it, at the same time saying he would come and see the fishing. I well ground-baited a likely-looking hole, and took the depth with the plummet the night before. At early morning I ascertained that fish were about. When evening came on I asked some ladies staying in the house to come out to fish. Twenty-four hours' judicious ground-baiting had acted as a dinner-bell to these water-foxes. The ladies had tremendous sport, catching very large carp, which on fine tackle gave great excitement.

I must say the French anglers are most ingenious as regards many points connected with fishing, especially in the matter of baits for fish ; and here is a ground-bait for 
earp which is well worth trying. Take a tuft of turf the size of a dinner-plate, the grass of which is green and short; then with a needle and thread, the thread being green, sew on red worms so as almost to cover the turf; fasten the turf to a board and sink it to the bottom.

I will now give the following excellent hint to anglers for carp, which I have no hesitation in saying is fair fishing, and will frequently dodge the carp when their manner is defiant towards the angler. In places where there are water-lilies and other floating broad-leaved weeds, put one single shot only on the gut, and place this shot on one of the leaves, allowing the bait, which should be a nice lively worm, to hang over the leaf. When you see the shot slipping off the leaf you may be pretty certain the carp has got the bait; give him time to get the worm and hook well within his leathery mouth and then strike. The astonishment of that carp will be great.

The muddy flavour of carp is due to the food which they eat, namely, the water-plants and the various insects and larvæ; especially, I believe, the larvæ of midges and gnats, which they find in the mud. Carp also eat young shoots of water-plants and large waterbeetles, and I recommend that in carp ponds the water should be let down, and grass seed sown along the edges and mud. When the grass has sprouted, shut the hatches, and let the water cover the grass, which will afford excellent pasture for the carp; and here let me tell proprietors of carp ponds that it is very cruel not to feed their fish (see page 334).

Carp have more than once given origin to fairy stories. I was told that fairies could be seen dancing on bright moonlight nights in a certain lake in Ireland. The water was very still but showed rings innumerable. 
These I found were caused by large carp coming to the surface and smacking their lips as they took in great gulps of air.

\section{PRUSSIAN CARP.}

\section{(Cyprinus gibelio.)}

Cyprinida.

Local names : The Crowger (Warwickshire); Gibel. French : La Carpe Gibèle. German : Der Giebel.

THis fish is often confounded with the common carp. The common carp, however, has two little barbules at each corner of the mouth, while in the mouth of the Prussian carp no beards whatever exist.

The Gibel Carp is thicker, more chub-like, than the common carp; it very much resembles the rudd. This fish delights in stagnant water, marshy and cattle ponds, and the flesh does not assume the taste of the water in which it lives. It lives a long time out of the water, possessing in this respect more vitality than the carp. There are two other kinds of carp: the Crucian Carp (Carassius vulgaris; German: Die Karausche; French: Le Carassin) and the Bastard Carp (Cyprinus Kollarii; German: Die Karpf Karausche; French: Le Carpe Kollar).

Acanthopteri.

\section{CAT OR WOLF FISH.}

\section{(Anarhichas lupus.)}

Blenniida.

German: Der Seewolf, or Seekatze. French: Le Loup.

Dutch : De Zeewolf.

THE Wolf Fish, or Sea Cat, is a most powerful brute. It is not unfrequently met with off the coasts of Scotland and Yorkshire; its food being shell-fish and crustacea, which it readily crushes by means of its strong teeth. It is remarkably strong, active, and rapacious; 
not unfrequently it enters the nets of the fisherman to plunder them, and when attacked it fights like a lion. The Germans and Danes call it the " Stone-biter ;" and, indeed, it fiercely bites everything presented ta it, not excepting iron. Notwithstanding the ugly appearance of this fish, its flesh is said to be of very good flavour. It is sometimes seen hung up in the shops of London fishmongers. In the northern countries it is salted and preserved, while the skin makes isinglass, cords, bags, pockets, \&c. In the "Sea Fisheries Report, 1865," a witness states that the cat-fish is often eaten; and I can, for my own part, say that it is very good; I can compare it to nothing but a nice veal-chop. I would not recommend any one to try his hand at fishing for "cat," as I am told by a North Sea fisherman that they can snap a broom-handle in two with the greatest

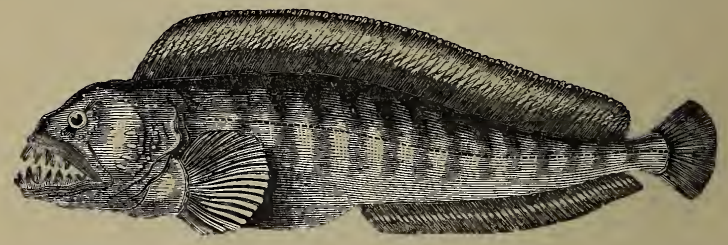

WOLF FISH (Anarhichas lupus).

ease. The following instance, from another authority, gives a fair notion of the power of a cat-fish's jaws : "A pair of cat-fish, of different sizes, were caught in a trawl from a yacht on the North Sea, about halfway between Grimsby and Norway. One of them, the smaller of the two, on being brought on deck, bit at a mop-handle which was held out to it so savagely that it was swung overboard without letting go its hold. When it was shaken off, one of its teeth was left 
behind it fastened in the wood." The other fish was killed, and the head presented to a museum. The sailors said that no doubt the net had caught them on part of a wreck, and that the cat-fish haunted the remains of a vessel, for they generally are in pairs, and are very fond of playing at "bo-peep" among pieces of timber, \&c. They must haveonly just been caught when the net was hoisted up, as none of the other fish were bitten. The sailors say that the jaws of the catfish are so powerful that they can bite off a man's arm; at any rate, they look vicious enough for any atrocity. These fish have very powerful long canine teeth in front of both upper and lower jaw, which has farther back a complete pavement of teeth above and below, which are meant for crushing hard substances. I was pleased to find a key to the use of these in a specimen I had presented to me by Messrs. Gibson and Quelch, of Bond Street. The stomach contained nearly two pints of the shells and bodies of the " soldier crab," or, as they are called, "Essex farmers." The fish had pounded these up to mince-meat. The soldier crabs, as we all know, inhabit the deserted houses of whelks and other shell-fish. I have several casts and preparations of this remarkable fish in my museum.

\section{THE CHUB.}

Abdominales Malacopterygii.

Cyprinida.

\section{(Leuciscus or Cyprinus cephalus.)}

Local names: Chevin, Loggerhead, Poll, Pollard, Skelley (Eden, Carlisle), the Headed Dace, Lob or Bottling. French : Le Chevanne, Dobule, Le Vilain Testard. German : Deckkopf, Der Hitel, Schuppfisch, Döbel. Italian: Capitone.

The Chub is remarkable for his hawk-like quickness of sight; even the shadow of the rod or a passing cloud 
will make him sink instantly. It will be found that he has a very large air-bladder, which enables him to ascend and descend in the water at will, with great rapidity.

The chub is found about mills, piles of bridges, weirs, in eddies, steep banks overhung with willows. He is a greedy fish, and will eat almost anything that falls into

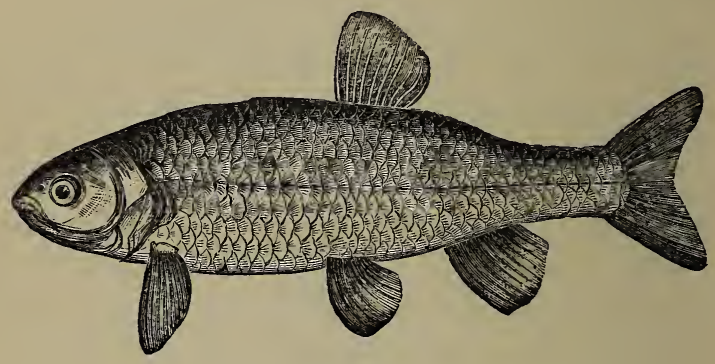

CHUB.

the water. When trolling for pike with a gorge bait below a weir, I had a run, and instead of a jack I caught a chub. When the chub is not full grown it is very difficult to know it from a dace (Leuciscus vulgaris).

A writer in the Fisherman's Magazine (No. 10, p. 14) gives the following diagnostic marks: "It is not in the proportions of the two fish, but in their colour, that the most ready and convenient mark of identification is to be looked for. By bearing the following rule in mind no fisherman can ever be in doubt as to whether the fish he has in his basket is a chub or a dace. The ventral (or belly) fins of the dace are greenish with a slight tinge of red, whilst the anal fin has no red about it whatever. In the chub both these fins are of a brilliant pink colour." 
It is quite evident that the French anglers have much trouble to catch M. Chevin. We read that the "defiance and experience of the chub are very great. They have very little appetite, being placed, like Æsop's animal, in the middle of the cheese. Living in clear water, they see the fishing-line, and turn up their nose at it in a disdainful manner." Another remark: "the angler wants to catch him with an invisible line; alas! one cannot find such an article."

"The chevin common is the grand Seigneur, for he lives at his ease: in the winter in the sun, in the summer in the shade of big trees; in hot weather on the surface of the water, in cold weather at the bottom, in deep and tranquil water; hence the wise angler will recollect when it is hot to fish for him near the top, and when it is cold, near the bottom."

The chub has the same fault as the Yorkshireman's horse-he is very bad to catch, and is no good when he is caught. His body contains an enormous quantity of hair-like bones. These bones are not placed without symmetry, and a chub, therefore, when made into a skeleton, either by gentles or the Dermestes beetle, forms a very beautiful object. Why a chub has such a remarkable skeleton I know not; and I should be much obliged if any of my readers could find out why the chub requires such a complicated system of bones. Mr. Chub is a great insect eater, and one of his objects in waiting nnder trees is to eatch the caterpillars and other insects which fall off the leaves. He is especially fond of grasshoppers, cockchafers, the large black slug, the large hairy caterpillar (but the angler should be careful not to get any of this caterpillar's hairs into his eye); he also likes a bluebottle-fly. He will probably take a blackbeetle, and any one who could find any economic use 
for blackbeetles would be a public benefactor. He has large leathery lips and a great mouth. "He bites so eagerly that when he takes the bait his jaws are sometimes heard to chop."

A capital plan to catch chub, where there are not too many trees, is to cross line for them; that is, one fisherman walks on one side of the river, the other on the other. The lines must be joined together in the middle and the baited hooks suspended therefrom by thin gut, and then dropped gently on the stream. Besides insects, the chub is very fond of old Cheshire cheese, and also the spinal marrow of a sheep or ox, called pith. I have also a strong notion that caviare made into paste would fetch him nicely. Although the chub has no teeth in his mouth, the angler may soon ascertain, by putting his finger well down into a live fish's throat, that he has teeth in his gullet; these are very pretty objects, they are easily taken out of the fish, and easily cleaned by scraping.

Chub spawn in April. Little or nothing is known of their mode of spawning, or where the eggs are deposited, whether they sink or float, whether they are cohesive or not, how long the eggs take to hatch out; all of which, I trust, some of my readers will kindly elucidate by actual observation.

\section{CHIMAERA, KING OF THE HERRINGS, OR RABBIT FISH.}

Holocephali.

Chimaradi.

THE Chimæra can certainly not be classed among the "Court Beauties," but should rather sit for a model to artists who desire to represent nightmares and other demons of darkness. Its general conformation is not 
unlike that of an elongated carrot with wings. The total length of the largest specimen is thirty-two inches; the fins are long and wing-like, and when outstretched they measure from point to point fourteen inches; they are very thin, almost transparent, and are doubtless admirably suited to the habits of the animal. The dorsal fin runs down the whole length of the body, and

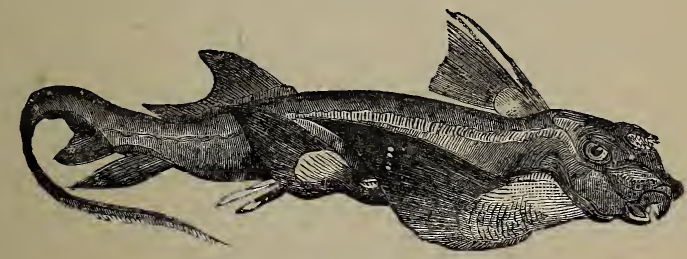

KING OF THE HERRINGS, OR RABBIT FISH.

terminates in a tail about the size of a whipcord, diminishing to that of very fine string, and then to the size of fishing-gut. Upon his back the chimæra carries a very sharp and formidable spine, the tip of which is as pointed as a needle; it is slightly serrated at its lower edge, and gives attachment to a large fin which probably steadies the fish in the water. This spine works up and down by means of a complicated joint.

The whole of this dorsal apparatus can be lowered so as to fit in a long and narrow depression in the eentre of the back. The action of this spine in raising and depressing the fin resembles that of a movable mast raising and lowering the sail of a barge.

The head has curious ribbed-like markings upon it, reminding one somewhat of the pattern of the armour on the sturgeon's head. The peculiar markings over the mouth and along the nose (which give the idea of the skin having been sewn up with a needle and thread) represent elevations on the skin which are 
found in pairs. The edges of these portions of skin are serrated, and they fit closely together so as to form a sort of canopy. Inside each canopy I find some peculiar white minute bodies. I have no notion of the meaning of all this.

The eye in life must have had a monstrous and fierce appearance; the lens is nearly as large as a small marble, which, when the fish first arrived, appeared to be of a beautiful sea-green colour. The eyes are directed well forward, and, together with the hideous nose, form a figure-head worthy the imagination of the nost barbarous Chinaman that ever designed a figurehead for a piratical war-junk. Upon the top of the head, nearly between the eyes, the chimæra carries a most curious crown of bone; it is about the size and shape of a large hook (such as used with "eyes" in millinery), and is directed forward towards the tip of the nose; its end is rounded, and covered by a multitude of sharp spiny processes, the largest of which are in the centre, the smallest on the circumference of this bone. If the bone be pressed backwards the spine-covered end will be found to fit into a cavity of soft skin, which appears to be specially placed there in order that the spines may not get injured. I have not the remotest idea what can be the use of this remarkable appendage. It is found only in the male. It is somewhat like a crown, and hence the Norwegians have called the chimæra the "King Fish," and also "King of the Herrings." In the female this crown is altogether absent.

Considering the formidable appearance of this fish, the teeth are ludicrously harmless. They project out from under fleshy lips, and resemble at first sight the teeth of a rabbit; hence the fish is sometimes called the 
"Rabbit Fish." The lower teeth seem to fit into the upper teeth, and they would almost appear to be rodent in action. They are very simple in structure-in fact they are scarcely teeth at all, but dental plates of triangular form; their structure seems to be tubular. When moist they are semi-transparent, and more hornlike than of the usual hard dental structure.

I fancy the chimæra must be herbivorous, for the teeth remind me more of the cutting edge of the jaws of the turtle than of any fish. Most unfortunately, the fishermen had removed the viscera of my specimen, so that it was impossible to tell what the fish had been eating.

Its native home is in the icy waters of the northern seas. I feel convinced, from its shape and structure, that we may conclude that it lives in very deep water, probably in the subaqueous caverns and grottos amid the rocky cliffs of the Polar seas. Its form doubtless enables it to glide with a quick and snake-like motion in and out the rocks in semi-darkness. I argue this latter point on account of the structure of the eye, which is decidedly that of a deep-sea fish, and also its bright and silvery lustre when first caught. The chimæra was, I believe, once the synonym of a fabulors animal, and was made the theme for a skit upon the Royal Society in its younger days. We read of a thesis being set in ridicule of its proceeding. The thesis ran as follows:- "An chimæra bombinans in vacuo possit producere causas secundarias?" ("Whether a chimæra buzzing in a vacuum can produce secondary causes ?") -a question which I believe has not been settled even by the present generation of philosophers. 
Anacanthini Thoracici.

\section{COD.}

(Morrhua vulgaris. Gadus barbatus.)

German: Der Kabljau. French : La Morue.

The family of the Cod-fish is very numerous, it contains no fewer than sixteen * recognised species of our native fishes (all of which, with the exception of one, are salt-water fish), besides four or five questionably admitted, or very rare.

Of these the Common Cod is a fish almost universally known in cold and temperate climates, being very generally distributed and extensively captured. It ranges from Iceland very nearly as far south as Gibraltar, but does not enter the Mediterranean. While the herring and mackerel families (coming in great shoals into

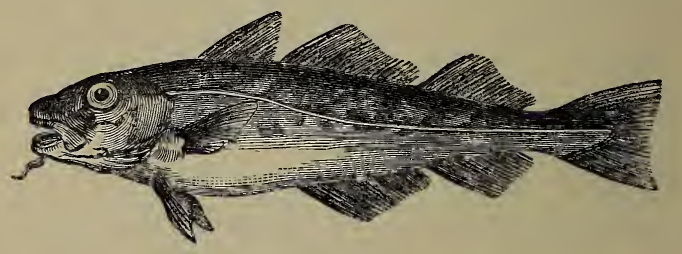

COMMON COD.

the shallow waters) are usually taken by nets, the cod is caught singly by hook and line. This fish rarely enters the shallows, but haunts the deep waters; feeding at or near the ground where it prowls about, rather than actively pursues any prey. It is a most voracious eater, and not at all particular as to the quality or nature of its food. Marine worms, crustacea, and shelled mol-

* They are, the common cod, haddock, bib, or pout, the power cod, whiting, coal fish, pollack, hake, ling, burbot, the threebearded and five-bearded rocking, mackerel midge, torsk, comm on fork beard, and tadpole fish, Couch's whiting and silvery gade. 
lusca form its most usual supply. I have several remarkable specimens of substances found in the stomachs of cod.

Mr. Grove, of Charing Cross, found in the stomach of a cod (which had been taken by hook and line), a piece of tallow candle-now in my museum-about seven inches long, and of unusual thickness. This piece of candle was shown to Captain Hill, of the North Sea trawler Hurricane, and he tells me cod-fish are not over nice in their taste. On one occasion he lost a bunch of keys overboard when off Cape Wrath. Some days afterwards the bunch of keys was found in the stomach of a cod caught "miles away" from the place where they were lost. He has also seen a guillemot taken, "feathers and all," out of a cod. He supposes the cod nipped the guillemot when it was diving.

In 1867, Messrs. Gilson and Co., of Bond Street, fishmongers, lent me a splendid cod, which weighed $481 \mathrm{bs.}$ and measured four feet four inches in length. I took a cast of it. The stomach contained four whitings, weighing in all eight pounds. He must have had a good appetite, for he had attempted to take a bait which had a hook in it in addition.

In March, 1872, Mr. Reed, of Wick, writes in Land and Water:-

There was landed at our harbour (Port Knockie) last wcek one of the largest cod, I believe, ever caught on our coast. Although this fish had neither roe nor milt, and was in rather poor condition, and not a particle of food in its stomach, it weighed $601 \mathrm{lbs}$. Had it been taken a week or two before, full of roe or milt, I believe it would have been the heaviest cod recorded as having been taken in British waters. The length was four and a-half feet; girth round thickest part, three feet. The head was enormous, being one and a-half feet from nose to gill-cover, and weighed 15lbs.

The tame cod-fish pond at Port Logan is now celebrated as a sight most dear to naturalists. In Septem- 
ber, 1869, I visited this pond, and was most hospitably received by General McDouall, of Port Logan House, near Stranraer, Wigtonshire.

After we had transacted our salmon business, the General took me down to see his tame cod. Near the bottom of the garden the sea has hollowed out of the solid rock a kind of amphitheatre about 100 feet in diameter. Formerly there was an iron grating to prevent the cod from going out; but now the passage is barred by a simple wall of loose stones, through which the water can come in, but the cod cannot get out. The tide comes into this remarkable chamber through a chasm in the rock about six feet in width. The water in the chamber is a considerable depth, and the tide ebbs and flows through the chasm, thus changing the water regularly.

The tide was out at the time of my arrival, but the pond was full of the most beautiful emerald clear sea water. The General has built some steps so as to get down to the pond from the level of the ground above, and he has also made a path round the edge of the pond.

Standing on the top of the steps, I could perceive some dark-looking bodies deep down in the water below. As we descended, these bodies began to move, and on arriving at the edge of the pond I saw a sight which was worth while coming all the way from London to behold. From almost every side of the pond, and from its deepest bottom, came darting towards us great opcnmouthed cod-fish. They seemed really to know personally Mrs. Towdie, the woman who is appointed as curator of the pond. She threw a mussel without its shell into the middle of the pond, and in a moment the surface seemed literally boiling with struggling fish. Gradually she threw the mussels nearer and nearer to 
the path where we were standing, and the fish followed them. So anxious were the cod to obtain the mussels that they came to the very edge of the pond, fighting for the food. I asked the General to send the woman away, but to leave her mussel-basket, in order that I might make my observations quietly; and this I did under great difficulties, as it was blowing a gale of wind, and raining cold rain in torrents.

I feel convinced that fish-at least General McDouall's cod-fish-have an intelligence for which we never give them credit. A cod's head and shoulders, boiled and put on the table, with its forlorn and woe-begone features, is a very different thing from the head of a hungry cod in perfect health looking for his dinner. The eye has great power of motion, great quickness, and I should say an almost telescopic vision-in water this of course. Again, the cod carries his three barbels or feeders on his lower jaw, stiffly protruded in front of his jaw, like the antennæ of an ant. They are exceedingly sensitive, for the moment I attempted to pinch one of them the cod drew back smartly. Among the other fish is a cod who has only one eye, but that is a piercer; they call him "Blind Tom." This old fellow came sailing round and round, with his blind eye away from me; but I managed, as he was passing with his blind cye towards me, to touch one of his feelers; it was a case of "threes about" in a moment; and when he turned round again, the old boy's solemn, half-frightened face and indignant glance of his one eye were most absurd.

Having plenty of mussels, and keeping very quiet, I made friends with these dear cod-fish. They all came quite up to the edge, just like chickens, to be fed. In their anxiety to get the food, they thrust their heads quite out of the water, and occasionally an energetic 
fish actually scrambled up the sloping side of the rock for a mussel ; but he never came so far but that his tail was in the water. They took the mussels with a tremendous gulp, making a gulping noise like the last sighs. of a pail of water as it retires down a sink-hole; and. here, for the first time, I found out that a fish has power, by means of his gills, to create an indraught of water towards his stomach, so that he does not depend entirely on his lips to seize his food.

After a time the cod and I became such friends that. they took the mussels freely out of my hand, and then I got another lesson as to the power of a fish's jaws. I held the mussel in my fingers and let them swallow my hand; their mouths were plenty big enough to take it in up to the wrist. Nobody can have any idea, unless they have tried it, of the tremendous power of a cod's jaws.

The rascals can nip uncommonly hard: their little rough, file-like teeth can hurt considerably. The bite amounts to a good sharp pinch, with a decided touch of saw-like motion: the pinching muscles are the part of the cod's head so good to eat. I fed my friends for about half-an-hour, and had ny fingers nipped almost. to bleeding by most of them. They were uncommonly sore for a week afterwards ; and at one time I thought I was going to get a poisoned hand, but luckily the threatened danger passed off.

I am afraid selfishness prevails among cod-fish as. among men, as I am sorry to find from experience. When a mussel was presented to the fish, there was a. rush at it; and it was a decided case of "first come, first served."

A very curious thing occurred; when the mussels. were all gone, I fed the cod with bits of paper, pieces of tobacco, official red-tape, bits of my mackintosh, \&c. : 
but they only came up to these things and then refused them. Suddenly I recollected that I had a dead viper in my pocket, which I had picked up that morning in the midale of the carriage road, with his back broken by a wheel. I took the viper out of my pocket and. waved it about with a snake-like motion in the water. To my great astonishment, the cod all swam away from it! I even tried the hungry little cod, who had been jostled out of the "soup kitchen" by the bigger fish; but no! even they turned up their tails at the viper. I tried them two or three times; always with the same result. At last one big fellow came up from the bottom like a rocket and swallowed at a gulp about half of the viper. I pulled at the viper's tail and the cod pulled at his head; he was a tough viper or he would have come in two. At last the cod let go, as though he had found out that this was not his proper food. I confess I am unable to explain how it was that all the cod except this one swam away from the viper. Have cod, like New Zealanders, a horror of snakes ?

I look upon a salmon as a highly intellectual animal -an aristocrat and a gentleman. The cod-fish is a common, vulgar creature, with a big mouth and rushing manners. When caught in the crowd in the Lord Mayor's show, I saw one of these London wide-mouthed, leaden-eyed blackguards, as like a cod-fish as a man can be like a fish. But yet I must not abuse the poor cod. They certainly have, when alive, an expression of their own, possibly also a language. Would that I knew how to speak it!

There seems also to be among fish, as among men, what the people in India call " caste ; " that is to say, a meeting of class A with class Z strikes a note of discord, which no amount of the so much vaunted education of 
modern days will create into a concord. In the General's pond was one salmon, who had not even the civility to come and shake a fin with me as a sincere friend of his family. He kept far away at the other end of the pond, and I never saw him but once. He seemed as black as a rook, and as thin as a starved-out inhabitant of Metz. No, it won't do to keep salmon in captivity. They are wild animals, and must be as free as the red deer or the eagle, or they will not prosper. The more I see of the salmon, the more I acknowledge he is my master. There is a certain divine afflatus about him, which naturally leads men to do a great deal for his benefit, and the more of this sort the better. No fish has ever had more laws made about him than the salmon. I hope I shall never hear a lawyer abuse a salmon; this would be base ingratitude.

And now for a sad end to my tale. The General kindly waited a very, very long time, while I was watching his fish. At last it began to get dark. He said: "Buckland, we must go to dinner, but we will take a cod-fish with us." Down the steps again came Mrs. Towdie, with more mussels, and a great white iron cod hook attached to the end of a line. As the General supplies his table regularly from the pond, and as the fish had to be slain as a matter of necessity, I was obliged to stand by and see the execution. Mrs. Towdie then artfully hooked out one of the biggest cod: the poor thing took the mussel with a gulp. Alas for feminine temptations ! who among us men has not been treated like this poor cod? His former protectress pulled him out of the water in a moment, and he heaved a heavy sigh as he flapped his tail for the last time. We had this fish for dinner-I regret to say, without shedding tears-and a splendid cod it was. 
Cod are very prolific. I received from Mr. Smithers, fishmonger, of Duke Street, London Bridge, in February, 1868 (see Land and Water, No. 108), a cod's roe weighing seven and three quarter pounds. Having cut off a portion and weighed it, and counted the eggs over twice to make sure, it proved on careful calculation to contain no less than $6,867,000$ eggs, or more than double the population of London. A cast of this is now in my museum.

I strongly advise my readers, who wish to see what the fishery wealth of England is, to pay a visit to Great Grimsby. Of this wonderful fishery port I have published the following description in my "Log-book of a Fisherman and Zoologist": "The most noticeable feature in Great Grimsby is an immense shed, called the Pontoon. It is about 300 yards long, and the floor of it is frequently covered the whole distance with freshlycaught sea-fish, these are sold by auction on the spot to dealers. Railway vans are brought up close to the Pontoon, and the fish are sent off daily by tons upon tons to London, Huddersfield, Halifax, Bradford, Leeds, Birmingham, Wakefield, and other large towns. Passing through the Pontoon we get a good view of the docks.

"Floating in the water are a great number of immense boxes, looking like gigantic dice. They measure about ten feet long, five feet wide, and four feet deep. In one place the boxes were so thick that the water could not be seen. These boxes contain live cod, and they get renewed water as the tide goes in and out, through the holes bored in the sides of the boxes. There are so many of these boxes floating about that men and boys are frequently seen walking about on the top of them, and jumping from one to the other, over a great extent of the dock. 
"One of these boxes was hauled up alongside a barge, and the lid opened for my inspection. The sight was most interesting and curious : there appeared one solid mass of living cod, all struggling and gaping with their immense mouths. This is a sight worth going all the way to Grimsby to witness.

"According to the supply wanted for the market, the cod are taken out of the boxes and 'felled' by a blow on the head with a heavy mallet. This is the best way of killing cod.

"In another of these boxes there was a large number of great halibuts. I had never seen a live halibut before. $\mathrm{He}$ is a curious-looking fellow, one side brown, the other a creamy white. The cod will live in the boxes eight weeks : they have no food given them. The halibuts will also live from eight to nine weeks. A cod weighing fifty pounds is considered to be a large fish; one was sold last year weighing fifty-two. A seventy-pound cod is the largest ever known. The largest cod are caught off Cromer Knowle.

"When walking round the dock I saw some men hauling at a rope; evidently the rope was made fast to something very heavy. When this body came to the surface, to my astonishment it consisted of a solid mass of live cod, each individual fish being tied by the tail to the rope. When the fish were in the water they spread themselves out in a circle, looking like a large cartwheel without the tire, only the spokes much more numerous. When the cod were hauled up into the air they looked like a rope of gigantic onions. The poor cods' tails seemed very sore and lacerated by the string which fastened them to the rope. These cod, poor beasts! must lead a miserable life, and I think this practice of tying them up very cruel. 
"Walking about the docks I saw some Dutch fishermen, very hardy, fine-looking men. I understand they are very clever fishermen, and can catch fish when nobody else can. The Dutchmen bait with limpets, the English-

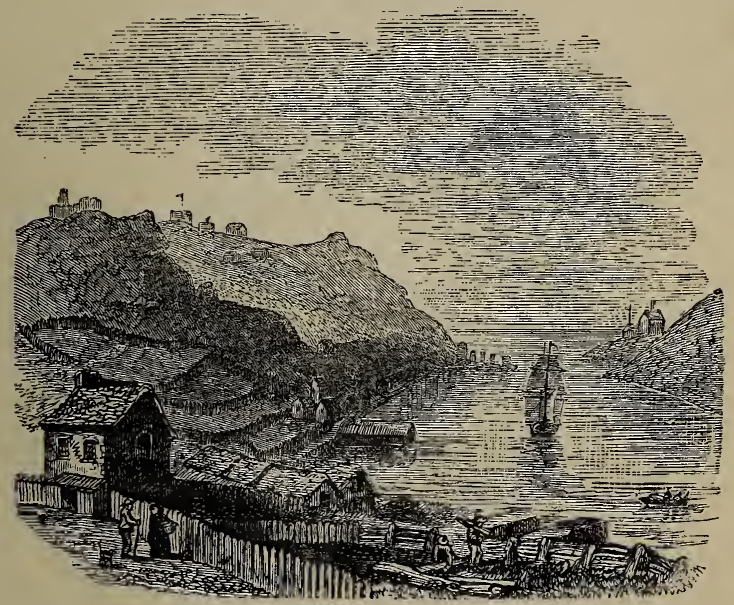

ENTRANCE OF THE HARBOUR OF ST. JOHN'S, NEWFOUNDLAND, WITH THE FISH STAGES.

men use lamperns, and in the cod season a great number of boys are employed putting lamperns (which are cut into little pieces) on to the hooks.

"The cod when caught are put alive into a well inside the hold of the trawler. They are taken out by landing nets. The cod will not live long in these wells when the vessels are in the docks. A very ingenious device for picking out any dead cod that might possibly remain in the corners of the well is a kind of gaff, consisting of two cod hooks hammered quite straight, with the barbs facing each other. 
Malacopteri Apodes.

\section{THE CONGER.}

(Conger vulgaris. Anguilla conger:)

German: Seeal. French: Congre. Danish: Havaal.

Italian: Grongo.

Congers are eels which are found in Cornwall, Devonshire, Jersey, and Guernsey, in Ireland, and in parts of France washed by the Gulf Stream. They are also found in considerable numbers among the great chalk rocks at the bottom of the sea in the neighbourhood of Dover; probably also in the Channel, right across to Boulogne, as I have seen some huge congers in the Boulogne market. These were destined for the Paris markets, where, no doubt, the French cooks formed them into "stock" for all sorts of dishes. The congers are very voracious fish. The power of the jaws is tremendous. They will eat almost any kind of fish, and are specially fond of crabs and lobsters. In the "Sea Fisheries Report, 1879," I have given tables showing the food of sea fish. The various substances found in the stomachs of congers may be thus enumerated-pilchards, dabs, soles, plaice, weevers, mackerel, herrings, etc. The best bait to catch them is cuttle-fish. When the cold frosty weather comes congers retire into very deep water and there remain in a state of semi-torpidity till the warm weather comes. The best time for congers is from March to October. The congers carry an enormous number of eggs. Mr. Jackson made out that his large conger contained between fourteen and fifteen million eggs. What becomes of this enormous number of eggs is unknown to mortal man. They probably form the food of many small sea creatures, especially crabs. The eggs of the conger are exceedingly minuts, and very like the eggs of the fresh- 
water eel, which are known to most persons as the "fat of the eel."

In March 1880, I received the following most interesting account from my friend Mr. C. L. Jackson, managing director of the Aquarium, Southport:-

"I forward you one of our congers which has just died, and as its size entitles it to be enrolled among the distinguished members of the finny tribe, as represented by their plaster busts in your piscatorial museum at South Kensington, I thought a short account of its life would be interesting to you. The fish is one of a number procured when we were first stocking the aquarium five and a half years since. Some of them were caught. at Fleetwood by Mr. Long and myself, while others were bought. They were all very small, not exceeding 2lbs. or 3lbs. weight. The deep-sea fishermen always said they could not keep the large ones alive, so we had none but little ones caught inshore. The fish now forwarded is undoubtedly a female, and has died full of ova, unable to part with it. Its length when taken out of the tank was 6ft. 5in., girth 2ft. 6in., and weight 90lbs. This enormous weight has been obtained in five and a half years, and as it only weighed two or three pounds when just caught, if we may take its subsequent growth as any criterion of its former progress, we must conclude it could not have been more than about a year old when caught, ergo, from being hatched to attaining such gigantic proportions only takes six and a half to seven years.

"There is something very curious about our shoal of congers. One of our lot died when we had them about two years; it weighed $21 \mathrm{lbs}$, and was enormously distended with ova. I counted the ova and sent you particulars, which you have referred to on several occasions. 
No others showed any signs of being in spawn until about a year and a half after, when the largest specimen began to swell very much; in about six months it died, weighing $691 \mathrm{lbs}$. About six months since the present specimen, which had much outgrown its companions, began to show signs of being in the same condition, and it has succumbed also, weighing 90lbs. We find these congers are the most voracious creatures we keep; they attack and devour even dogfish, and these of a size that one would think beyond their powers of swallowing. We have quite given up keeping the piked dogfish with them, and even the topers must be big ones, or down they go. The only safe things are our big sturgeons, monk-fish, skate, and the huge turbot we have reared from little ones (these latter continue to grow). Congers swallow their prey head first, as a rule, but when committing an act of cannibalism they swallow their small brother often, if not always, tail first. If the youngster is a bit too big, you may often see him three parts swallowed, and when the big one is quite exhausted, the other will wriggle out none the worse, except that it is scratched by the big one's teeth. We have had this happen so often with the same fish that at last it has got as ragged and full of scratches as it could hold; some day, however, one of the big ones has given a mighty gulp, and once let its jaws close over the head of the little one, and we see it no more."

In the Appendix to the Sea Fishery Report, which has just been published, I have given the weights of the largest congers that have come under my notice. In $1878 \mathrm{Mr}$. Jackson, of Southport, sent me a conger $691 \mathrm{bs}$. weight, $6 \mathrm{ft}$. $5 \mathrm{in}$. in length, and $2 \mathrm{ft}$. $5 \mathrm{in}$. in girth. Mr. Dunn, of Mevagissey, informs me that the largest conger ever taken at Mevagissey was caught by Maxwell 
Dunn and James Hicks, and weighed 112lbs. On the same night that they caught this extraordinary fish these fishermen caught another of 70lbs. and another over $601 \mathrm{bs}$. I heard of a large conger being landed at Falmouth whose length was $7 \mathrm{ft}$. $4 \mathrm{in}$.; girth $2 \mathrm{ft}$; ; and weight

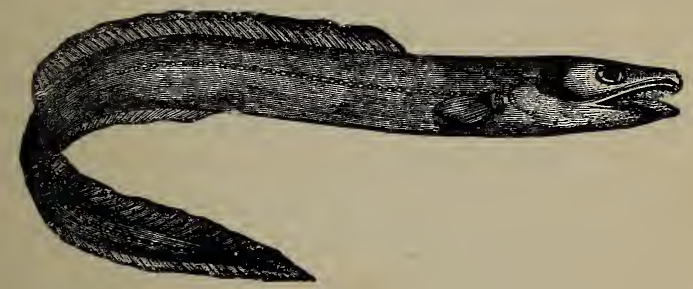

CONGER EEL.

72lbs. In November, 1868, I received from Mr. Ledger, of Folkestone, a very large conger. It measured 6 feet 4 inches, and weighed 50lbs. within a few ounces; girth, 21 inches. Three casts of this magnificent fish are in my museum. There are also casts in the museum of a conger from the Lower Shannon, which measured 6 feet 9 inches; girth 20 inches. I have given my reasons in Land and Water for thinking that monster congers may sometimes-nay, often-be the origin of the stories about the "Sea-snake."

I also received from Mr. Joseph Robinson, of Limerick, in June, 1869, a conger caught in the Lower Shannon. It measured 6 feet 9 inches; greatest girth 20 inches; it was nearly black. The Folkestone congers are of a grey-slate colour. In Land and Water, No. 178, I have attempted to show that Virgil's sea-snakes, which devoured Laocoön, might have been suggested to him by having seen some monster congers swimming. 
The following notes on congers I have published in my "Curiosities of Natural History," 2nd series, Bentley, 1875 :- The first sight I got of the congers at Folkestone was in a "lug sail boat," which ran in at high tide in company with a fleet of trawl-boats, laden with congers, or rather marine boa-constrictors. When the boat stranded, the men threw them out on the shore one by one, and there they lay, just able to wriggle, and to gasp with their formidable mouths. Some of them were of a pale white colour, but the majority were sprinkled here and there with nut-brown markings, making them look much more snake-like than when hung up in Billingsgate. The crowd gathered round. "Who will buy this parcel of congers?" said the fisherman, picking up a stone, and standing with the congers all placed before him. The biddings went on fast. $£ 15 \mathrm{~s}$. was bid for the lot, in number twenty-one, large and small; down went the stone, and the purchaser hastily pitched the great brutes into " kittens," as they call the fish-baskets, and in twenty minutes the congers passed me in the open luggage-van of the train on their road to London. These were "Ness congers," and were caught on a "long line."

When the long line is hauled the hooked congers sometimes (if they are big ones) "yawls on the lines;" sometimes "they comes up quickly;" at other times "they hangs like a log of wood;" but they nearly always " makes a curl with their tail, so as to hang back in the water;" when in the boat they try to get out by "clinging their tails over the side." (I have observed this same fact with fresh-water eels.) To get them into the boat the fishermen have an enormous "heal," or "prule," i.e., a gaff-hook. When in the boat " the congers are terrible things to bite, sure-ly." 
To kill them, "it's no use knocking them on their great heads, no more than a great bull; just hit'em a sharp smack on the belly, and that turns 'em up directly, because all their blood lays there."

One of the fishermen, George Smith, caught a "whacker" last year. When he hauled the line he thought "he had got hold of a wreck," but he managed to pull him up gently to the side of the boat, and whip the "heal "into him. He "kicked up Mag's diversion" in the boat, and nearly got out again; so Smith tied him by the "beckett" to the thwart of the boat with a new French whiting line, which Master Conger broke three times. Smith himself, who is a very powerful man, tried afterwards to break the same whiting line, but could not. This conger measured 8 feet within an inch, and was 26 inches in girth at his fins. He was sent off to London directly in a "kitten," or fishhamper, all to himself.

One day a French fishing-boat came into Folkestone from Portelle, near Boulogne, the weather being too rough for them; they had a few small congers on board, and I observed that they had been baiting their "snoods" with the arms of cuttle-fish cut into bits. They called all Englishmen "John," and when I went to talk to them a red-nightcapped fellow held up a dogfish, and said in broken English, "Vil you buy a dog, John?" I did not buy the dog, but I got a conger's head for threepence. The Frenchmen turned out of their boats in the afternoon, and boiled the conger's body on the beach, putting sundry odd scraps of fisl into their pot as well. As a bystander said, "There's: very little fish as them chaps heaves away; they eats a'most anything."

Congers are exceedingly sensitive to frost. Dr. 
Turner, of Hastings, informed me that in January, 1855 , thousands of congers were found floating upon the water. They could progress readily in any direction, but could not descend, and consequently fell an easy prey to the boatmen. The Folkestone fishermen also took an enormous quantity of congers at this time. One man brought home 800 in his boat. The same cause acted on the Folkestone as upon the Hastings congers, viz., the action of the frost caused the air in their swimming-bladders to expand so much that the ordinary muscle could not expel it at will.

The Folkestone fishermen explained this phenomenon thus: "You see, sir, the conger comes up to the top of a frosty night to look at the moon, gets nipped by the cold, and can't get down again." Barring the moon part of the story, their theory is correct.

My friend Mr. Roberts, of Dover, sent me the following note on this subject: "After a sharp snow-storm I saw picked up behind the cob at Lyme Regis, Dorset, several hundred reä rock, or sea perch-called locally 'conners' - small ' blins,' i.e., whiting poults, and conger eels. The peopie came to pick up the fish blinded by the snow on Christmas-day. They were lying stranded among the sea-weed. There may have been five hundred fish at least of eatable size, and about three hundred smaller ones."

Abdominales Malacopterygii.

\section{DACE.}

\section{(Leuciscus vulgaris.)}

Local names: Dace, Dare, Dart. French: Vaudoise, or Dard. German : Ler Hasling, or Die Hasel.

Depth of body, about the same as length of head; back fin commencing half-way between point of nose 
and end of fleshy portion of tail; tail fin small, and a good deal forked; scales smaller than those of the chub, fifty on lateral line. The dace has the vivacity of the bleak and the swagger of the chub, therefore it requires some little attention to catch him. $\mathrm{He}$ is in full season from October to January. Unfortunately for himself, he has such bright scales that he makes a splendid live bait for pike.

Considerable discussion has lately taken place in angling circles as to the use of live bait in angling for pike. In India, when they set a trap for a tiger, it is stated that they tie up a kid, and to make him cry they put a stone in his ear.

A gentleman who was a great hand at crocodile catching with the hook, told me the best bait was a sucking pig, and to attract the attention of the crocodile the angler walked along the bank pinching the sucking pig to make him squeak. Both the pig and the goat when used for bait exhibit considerable fear. The poor dace used as a live bait is probably also in trepidation, if he knows the purpose for which he is made captive with hook run through his back. His Grace the Duke of Wellington, a great angler, has therefore invented an ingenious apparatus by which the bait is held secure to the hook by means of india-rubber bands.

At certain times of the year the dace assemble in vast numbers at the lower side of the Thames Navigation weir. The fish are then certainly heading up to spawn. Passes should be made for them to ascend, and I hope shortly to suggest a plan for fish passes, either through or round all the weirs on the Thames which are found to obstruct the fish. 


\section{SQUALIDE. DOG-FISH.}

Plagiostomi Squali.

Scylliida.

The following is a list of the Dog-fish most common in British seas :-

\section{THE PIKED-DOG.}

(Squalus acanthias. Galeus acanthias. Acanthias vulgaris.)

Local names: Bone-dog, Common-dog, Dog-fish, Hoe, Skittle-dog, Spear-dog, Spar-dog, Doggar. German: Der Dornhai. Danish: Haa, Pig-hay. Dutch: Doornhaii. French: L'Aiguellat.

This fish is oviparous.

\section{TOPE, OR TOPER.}

(Squalus galeus. Galeus vulgaris. Canis galeus.)

Local names: Common Tope, Penny-dog, Miller's-dog, Rig, Sweetwilliam, Tomhay, White-hound. German : Der Schweinshai, Milander, Meersaw. Danish : Blaahaj. French : Le Miilandre Chien.

This fish is viviparous.

\section{SMOOTH HOUND.}

(Squalus mustelus. Mustelus lavis. Mustela vulgaris.)

Local names : The Ray-mouthed dog, the Skate-toothed Shark, the Bastard Rig, the Hull Cock, and the Stinkard.

This fish is viviparous.

\section{LARGE SPOTTED DOG-FISH, OR NURSE HOUND.}

(Scyllium catulus. Scyllium stellaris.)

Local names: The Larger Spotted Dog-fish, Nurse-dog, Nesshound, Bounce, Bull-huss, Iobrin. German: Katzenhai. Danish: Rodhaj. Swedish: Katthaj. French: Rousette. Italian : Scillio.

This fish is oviparous. 


\section{SMALL SPOTTED DOG-FISH, OR ROUGH HOUND.}

(Squalus catulus. Catulus minor. Scyllium canicula. Scyllium catulus.)

Local names: Huss, Robin Huss, Rough-hound, Row-hound, Spotted Shark, Morgay, Lesser Spotted Dog-fish. German: Der Hundshai, Seehundchen. Dutch:Hondshai. French: Rousette.

This fish is oviparous.

\section{BLACK-MOUTHED DOG-FISH.}

(Scyllium melanostomum.)

\section{DOG-FISH IN GENERAL.}

When at Folkestone I learned much about Dog-fish, and now quote from my "Curiosities of Natural History ":-

Most of the fishermen's houses in Folkestone harbour are adorned with festoons of fish hung out to dry. There was no head, tail, or fins to them, and I could not make out their nature. The rough skin on their reverse side told me at once that they were a species of dog-fish. I asked what they were. "Folkestone beef," was the reply. "What sort of fish is this?" "That's a Rig." "And this?" “That's a Huss." "And this other?" "That? a Bull Huss-that's a Fiddler." "And this bone?" "That's the jaw of Uncle Owl," \&c.

Here then was a new nomenclature, which I cleared up with the following result :-

A "rig" is the common tope (Yarrell); a "bastard rig" is the smooth hound (Yarrell); the "huss," or "Robin huss," is the small spotted dog-fish; the "bull 
huss," the large spotted dog-fish ; the "fiddler" is the angel, or shark ray; " uncle owl's jaw" belonged to a species of skate.

Nearly all these various kinds of dog-fish are caught by the men who" go out after rigs" to the "hungry ground," over the Warne sands; and they catch them. with "long lines," laid down all night.

Some of the large rigs are nothing more nor less than sharks of the English waters. They have teeth of a triangular shape, exceedingly sharp, and so arranged that if one is broken off another comes up into its place. "You see, sir, they has jaws as tears ye like a bramblebush." The skin is not covered with scales, but with an: exceedingly tough armour, which sets the teeth on edge. when felt, and is " a terrible thing to dull your knife." When the rigs, \&c., are caught out at sea, they are thrown down to the bottom of the boat, and as they jump about there, they can be heard "grating one against the other." A rig lives longer than any fish in warm weather, but dies soonest in cold. When the lines are hauled, and there are a lot of freshly-caught savage rigs at the bottom of the boat, the men are obliged to be careful not to get bitten. "They all goes mad, sir, and it's like being among a lot of wild beasts." They have been known to catch hold of the men's "barbel," or fishing petticoat, and shake it. They are vagabond curs of the ocean, that go prowling and snapping about anywhere and anyhow for food. The fishermen hate them because they do so much damage to the herring-nets, eating the fish actually out of the net, and often rolling themselves right up in it. Ten minutes. after the arrival of the boats the small fish-dealers may be seen cutting off their heads, tails, and fins, and splitting them into halves; they are then salted and hung 
out to dry, and taste, when broiled, "like veal chops. They are eaten by the poorer class, "as a relish for brealkfast." The great heads, and the intestines, \&c., are left in the harbour till picked up by the owners of crab-pots or stalkers for baits. The livers are cleaned and boiled for oil for the boats in winter. There is an immense deal of gelatine in these heads and fins, and I tried in vain to persuade the men to boil them up, quoting the example of the Chinese, who esteem shark's-fin soup as a great delicacy.

The rigs have a long projecting nose (one species of shark is called by the sailors "old shovel-nose"), and this nose is of the same service to the rig as the snout is to a pig, for with it he routs about among the sand for small fish. The plaice, sole, \&c., are essentially hiders in the sand, and the dog-fish comes and routs them up with his nose, and then snaps them up as they attempt to escape. I found several of these small fish in their stomachs, and in one monster the skin and the dorsal spikes of his cousin, the "pike dog-fish," called by the men, the "spur-fish." In Dorsetshire they call them "spur-dogs." In order to see how this nose acted, I pressed a rig's head into a heap of wet sand and shingle. It was quite marvellous to remark how beautifully the nose was fitted to its work: man, curiously enough, copies its shape exactly in the instrument used for paring turf. On making a section of the nose I was much struck at its internal anatomy. It is not solid, for that would be too heavy; the outer skin forms a framework, and from side to side firm white strings are stretched across so as to make a series of chambers, which are filled with a beautiful white gelatinous fluid. The organ of smell is highly developed, and the delicate membrane on which the nerves are spread (answering to the 
Schneiderian membrane in our own bodies) is defended by a fold of skin to keep the sand out of it, answering to our nostril. The eye, when fresh, can be compared to nothing but a cup hollowed out of a large pearl, containing a diamond as its lens, and powerful muscles move it in all directions. On sinking the head in clear seawater, the eye glares like a cal's eye in the dark. I can fancy nothing more horrible than the glare and terrible rolling of this merciless, ravenous sea-tiger, deep down under water, and can well understand the piercing cry of horror which a human being naturally utters when he sees the murderous glance of the pursuing and maneating shark.

In July, 1868, two dog-fish were sent me by Commander Whyte, of Instow, Devon; the larger, which was 51 inches long, was the Common Toper (Squalus galeus), or White Hound; the female fish was Squalus mustelus, or the Smooth Hound-the ray-mouthed dog, skate-toothed shark of Couch. The number of young ones was eleven, all the very image of their dear mamma. Ten of them were loose and free from any covering; but I found an eleventh still in situ. It was wrapped round with an exceedingly fine and delicate membrane, as transparent and fragile as a gossamer veil. This membrane formed a loose bag, which, when spread out, would have been as large as a pig's bladder. Doubtless, the other young ones also had each private apartments in the form of a hag, but it had been torn off. It appears extraordinary that among the family of dogfish, which apparently lead very similar lives in the sea, some should be oviparous, and some viviparous; it is also interesting to remark, that whereas non-predacious fish multiply at an exceeding rate-their eggs counting by thousands, more often by millions-that predatory 
and carnivorous fish should have but few young ones at a time. Thy obvious meaning of this arrangement, which Nature has evidently inserted as a "protective clause" in her bill for "the due balancing of life among sea-fish," is that the oppressors should not overbalance the oppressed. We find the same arrangements among land animals-carnivorous animals have few at a birth, herbivorous animals have many.

The name " dog-fish" is a happy one, for this class of fish seem to have the habits in the sea somewhat similar to dogs on land. Wild dogs on the sand deserts of Africa hunt antelopes in packs; the "sea-dogs" hunt herrings, whiting, \&c., on the submarine sand deserts of the North Sea, also in packs; and old Neptune doubtless has fine sport mackerel hunting on the Warne Bank off Folkestone, with his "spotted dog" pack. Dogs on land have an acute sense of smell and hearing : look at the oifactory organs or dissect the ear of the "sea-dog," and you will find that he also would be good at hitting off a scent, or hearing the noise of "priming herrings" from afar. Fox and greyhounds have long tails, and they can turn quickly; the sea hounds have also long tails, and doubtless in the water would score points and "turn the hare" as weil as the best greyhound that ever ran at Hampton Court.

In the case of the Rough Hound (Squalus catulus) the young are not born alive; the parent fish deposits an egg, of which I have two specimens now before me, thrown ashore near Herue Bay. They consist of a thick horny substance, which when dry exactly resembles amber. Each egg is fasteneci to the sea-weed by means of two long string-like tendons.

These curious strings exactly resemble the tenärils of a vine, and it is a very curious circumstance that 
Nature seems to have used the same kind of ligature to fasten up the branches of a plant and to anchor the egg of a fish. The tendrils of the egg of the nurse hound are, when only slightly stretched, ten inches long.

Mr. Henry Lee was the first to discover, at the Brighton Aquarium, the mode in which these dog-fish managed to fix their eggs.

The Piked Dog-fish is the most common of all the sharks, and found everywhere in the British and Irish seas. It is at once distinguished from all others by a single spine, placed in advance of each of the two dorsal fins; whence its name " pick," being synonymous with pike or spike. It measures from three to four feet, and is of a blue slate on the upper parts, the under being yellowish white. The wounds it inflict are severe and bad to heal.

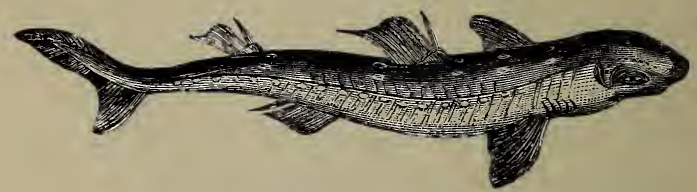

PIKED DOG-FISH (Squalus acanthias), COMMON DOG-FISH (Acanthias vulgaris).

These fishes often make their appearance in vast numbers, and among the Western Isles and Orkneys they are salted and dried for food. The livers yield a quantity of oil, and the offal makes manure. The Scotch call this fish Hoe; while on the southern coast it goes by the name of Bone-dog. It is ovo-viviparous, and produces many young at a time.

The Common Tope (Squalus galeus, Cams galeus, Galeus vulgaris), known by the names of Penny-dog, or Miller's-dog, is not unfrequent along the southern coast of England and Ireland, but is less plentiful in the 
THE PIKED DOG, THE TOPE, AND THE SMOOTH HOUND. 75

north. It is not unlike the dog-fish, but the number and position of the fins are the same as those of the blue and white sharks. It is a rapacious species, but not so destructive as they are. The largest specimens are about six feet long, and abound, in summer, on the. Cornish coasts.

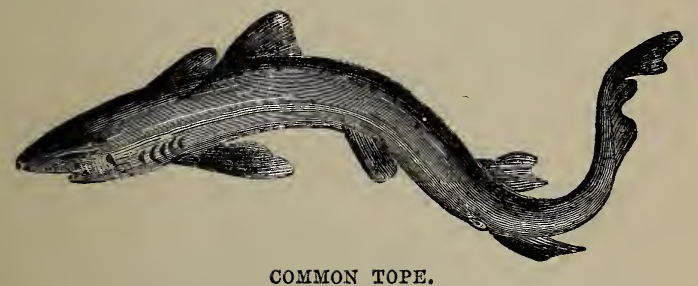

In August, 1867, my friend Mr. Cecil Martyn sent me a remarkably fine specimen of the Toper-Penny Dog (Hastings), Miller's Dog (Cornwall); it weighed about $30 \mathrm{lbs}$., and measured 4 feet 11 inches. I have made a cast of it, which is now in my museum.

The Smooth Hound, or Skate-toothed Shark (Squalus: mustelus), is rather a common species on most parts of the coast. Its teeth are flat and blunt, forming a closelycompacted pavement on each jaw, and greatly resem. bling those of the skate. Its skin is much smoother and softer than that of the sharks in general. It is:

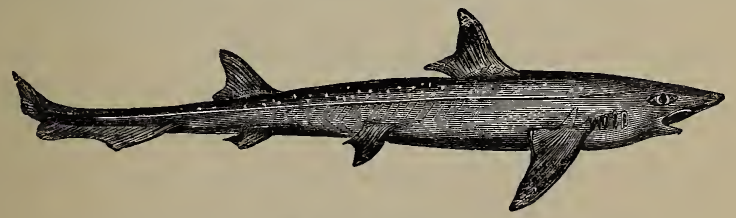

SMOOTH HOOND.

from three to four feet in length. It keeps close to the bottom on clear ground, where it feeds on crustaceous animals, which it readily crushes with its tesselated teeth. The young are produced alive. 


\section{DORY.}

Acanthopteri.

(Zeus fiber:)

Zeida.

German: Sonnenfisch, St. Peterfisch. Sweden : Silfveroga. Dutch:

Zonnevisch. French: La Dorée. Italian: Pesce San Pietro.

This fish in Sicily is called Gallo - the Cock-from the crest on its back; and in many towns of the Mediterranean it goes by the name of St. Peter's fish, because

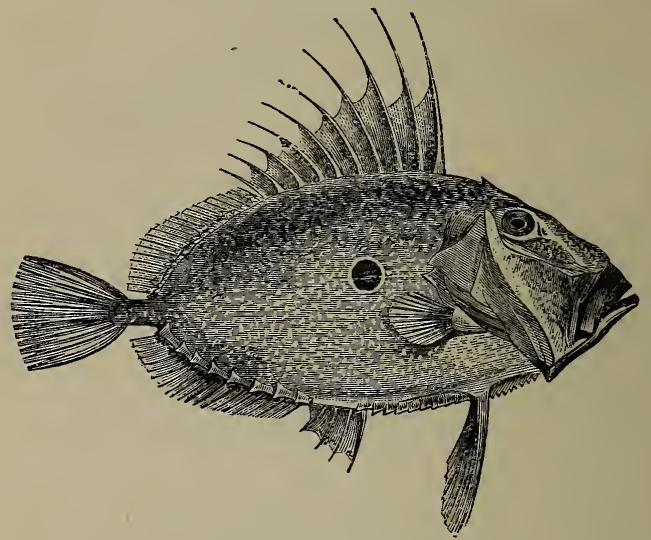

DORY (Zeus faber).

of the mark on its sides, supposed to be the print of the apostle's fingers-an honour shared with it by the haddock, which bears similar insignia.

The prevailing colour of the body is an olive brown, with yellow tinge, reflecting in different lights blue, gold, and white. When the fish is first taken out of the water these varying hues are seen in rapid succession. As a delicious luxury this fish has obtained high repute. The dorys of the London market are chiefly supplied from the Devonshire coast. They are better for being kept two or three days. 
There is one habit of this fish, Mr. Couch says, well known to the hook and line fishermen. The dory will frequently retire to the rough ground, or make a slight depression in the sand. Thus, half-hidden, the tendrils of the dorsal fin are allowed to float about like so many worms, to the temptation of all hungry passers. When a small fish-cuttle, or in fact anything-has laid hold of the tendrils, the powerful ventral fins are brought into play; up starts the fish, and opens its capacious mouth to receive the unwary victim. It also pursues its prey by a rapid succession of jerks. Mr. Quelch, of Bond Street, informs me that he took from the stomach of a dory, weighing $11 \mathrm{~b}$. 1oz., eighteen sprats, two sandsmelts, and one cuttle-fish, besides a number of smaller ones in a partially decomposed state. The total length, when placed in a line, of the twenty-one fish the dory had swallowed, was $5 \mathrm{ft}$. 8in., the length of the dory itself was $14 \frac{1}{2}$ in.

Dorys are subject to very curious excrescences which grow from various parts of the body; for instance, one specimen sent me had in its nose a mass of white substance, which, when opened, disclosed a vast number of round white bodies exactly like eggs. I have since received another specimen with a lump on its back, also containing these egg-like bodies. If you look in the gillis, you will of ten find most curious parasites.

Acanthopteri.

\section{BOAR-FISH.}

(Capros aper. Zeus aper. Capros sangiier.)

IN December, 1870, Mr. Charles, of Arabella Row, Grosvenor Place, was kind enough to send me "a curious fish;" the dimensions were, four inches long and three 
deep. It was the boar-fish (Capros sanglier). I have received several specimens since.

In Land and Water, 1880, my friend Dr. Day has published the following remarks :-

"I happened to be present when sixteen examiples arrived at Westminster Aquarium, from Mr. Dunn, of Mevagissey. They were all of a rich red hue, while most of them had a dark band over the base of the tail just before the origin of the caudal fin; the outer edge of the ventrals was also dark-tipped. One had faint traces of vertical bands, and another had a row of black spots along the base of the dorsal fin.

"The captures recorded in the British Isles are in Mounts Bay, October, 1825; at Bridgwater in 1833; Teignmouth about the same time; Lossiemouth in 1839 ; on March 6,1842, on the beach at Brighton.

"At Falmouth in 1841, and on August 12, 1843, the shore on the western side of Plymouth was strewn with numbers captured by trawlers, who threw them overboard when turning out their nets. The fishermen stated that within a few years these fish have swarmed to such an extent as to have become a perfect pest, and that in many instances the trawlers have actually been obliged to change their fishing ground in order to be out of their way.

"One from the Scilly Isles in 1870 ; one from Torcross in 1875; and a shoal of fifteen taken on the southwest coast of Cornwall. In 1879 a number were washed ashore at Poole, during the night of March 30, some of them contained spawn, which Mr. Penney considered were delicious, their flesh possessing a creamy whiteness and a delicate flavour. April the same year two were recorded from Exmouth; two from Torquay in February; in May one was picked up on the beach 
at Eastbourne ; and another brought alive into Grimsby from the mouth of the Humber."

Mr. Dunn, of Mevagissey, in his very interesting remarks upon the fishes of that locality, written in October, 1878, observes:- "Common here from the Start to the Lizard; these past five years they seem to be on the increase, thousands are yearly caught by Plymouth trawlers off Deadman headland, and thousands more are brought to land by our drift fishermen. In June and July last year I had over 150 alive in my tanks at one time."

Malacopteri Apodes.

EELS.

Anguillida.

German: Der Aal. Swedish: Al. Dutch: De Paling.

French : Anguille.

THERE are three or four distinct species of the freshwater eel inhabiting this country.

The Common or Sharp-nosed Eel inhabits all our fresh waters, abounds throughout Europe, except in the Arctic regions, and in some of those rivers which have their source in very cold districts; it is found in Asia also, and, in short, in almost every part of the world. The eels in New Zealand are very large.

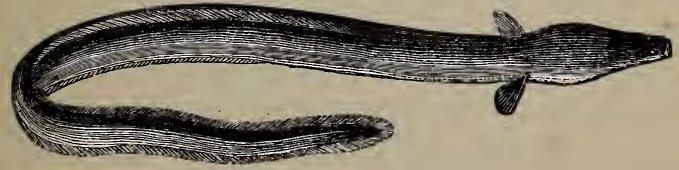

COMMON EEL.

The Broad-nosed Eel (Angilla latirostris) is almost as common a species as the preceding. It differs in the shape of the head, which is much broader, the nose blunter, and the skin thicker than the common sort. It 
is probably the "Frog-mouthed eel" of the Severn, so called by the fishermen from the width of the mouth. It exists in many of the waters which produce the sharpnosed eel, and is much thicker in the body in proportion to its length.

The Snig Eel (Anguilla mediorostris) is another species which occurs chiefly in the Avon, in Hampshire, where this eel, rather remarkable for its yellow colour, is considered distinct from the common sorts. There are some differences in its external formation and habits, as well as in the size and character of the bones. The Hampshire snig differs from the others in roving and feeding during the day-time, the other species being nocturnal. It is considered excellent as food, but does not attain a large size, seldom exceeding more than half a pound in weight.

The fishermen make a certain difference in the mode of placing their eel-pots when they are desirous of catching " snigs," finding by long experience that the snigs get into those pots the mouths of which are set in the opposite direction, in reference to the stream, to those in which the common eels are taken. In the comparative breadths of the nose, the snig holds an intermediate position between the sharp and broad-nosed eels, rather more resembling the former. It has a slight but elongated depression, extending from the anterior edge of the upper jaw to the upper and back part of the head.

Eels are sometimes found of a lovely golden colour; and I have also seen two specimens of albino eels, the skins being nearly white.

Various methods are resorted to to intercept eels while they are on their autumnal migrations. The apparatus used on the Thames, called an eel-buck (of which a figure is here given), consists of a number of wicker- 
baskets supported on a wooden framework. The large open end of each basket is opposed to the stream, and, by the peculiar construction of the inside, which is like a mouse-trap, a fish, having once entered, cannot escape again. A set of these eel-bucks can be seen from the bridge over the Thames to the east of Maidenhead

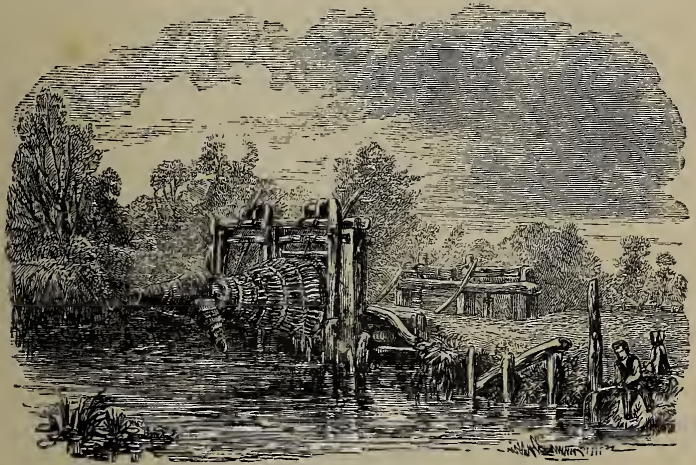

EEL-BUCK.

station, on the Great Western Railway. In Land and Water, No. 383, May 24, 1873, have published diagrams and descriptions of eel-nets as used in the Severn between Gloucester and Worcester.

The eel fisheries in Ireland are exceedingly valuable. Very large numbers are caught in the autumn months, as they are descending from the lakes to the sea-they generally run on nights when thunder is about-and are put into boxes and screwed tightly down when alive. I consider this to be a most cruel proceeding; the poor things must suffer very much screwed down in those dreadfully narrow quarters. This is a subject well worthy of the attention of the Society for the Prevention of Cruelty to Animals.

I have heard of an old Irish fisherman who used to 
set his eel-nets and then beat a drum. His reason was this: "Bedad, sir, it's just to make the eels run ; they think it's a thundery night."

I have heard that the eel fishery at Ballisodare, in Ireland, has been greatly improved and increased in annual value by making a pass for elvers over a natural obstruction. This is done by placing ropes of straw loosely plaited, up which the elvers climb. This is a hint that may be useful to other proprietors of eel fisheries. I have much more to write about elvers, but have not space.

The London market is principally supplied from Holland, the eels being brought over in Dutch vessels. A free mooring was given to these Dutch skoots by Queen Elizabeth, and boats have taken advantage of this privilege up to the present day.

In various localities eels run to a large size, some of the weights of which are recorded in various numbers of Land and Water. Thus, one was taken at Tewkesbury weighing $7 \frac{1}{2} \mathrm{lbs}$. ; at Stag Park, Petworth, one of 5lbs.; in the Arun, one of $4 \frac{1}{2} \mathrm{lbs}$., and another of $9 \mathrm{lbs} . ;$ in the Richmond Round Pond one of 5lbs. 140z.; at Bulford Mill, one of 4lbs., which had been seen to draw the young ducks down into the water. In one of the broads near Great Yarmouth an eel was taken in a tench bow-net of 7lbs., and in the same broad one of $61 \mathrm{bs}$. and $6 \frac{1}{2} \mathrm{lbs}$. ; another near the New Mills, Norwich, turned the scale at $7 \frac{1}{4} \mathrm{lbs}$; another on 13 th January, 1869 , in the very same spot, of $8 \frac{1}{2} \mathrm{lbs}$. Eels of 5lbs. and 8lbs. are not uncommon in Norfolk. An eel was taken in 1869 in the Ouse (Hunts), at St. Ives Staunch, $7 \mathrm{lbs}$.; and two of $6 \mathrm{lbs}$. each about the same time at Hemingford Grey Mills, on the same river.

In the year 1850 an eel of $8 \frac{3}{4} 1 \mathrm{lbs}$. was taken from the 
pond of Dutford Mill, and twenty-one eels were taken out of the eel-trap at the same place, whose united weight amounted to 84lbs., and one of the eels was not 6oz. in weight.

The largest fresh-water eel I ever examined and cast was a magnificent specimen sent in May, 1878, by $\mathrm{Mr}$. John Welch, eel salesman, Billingsgate. It measured 4ft. 4in. in length, 10in. round, and weighed just upon 10lbs. It was taken in the river Mole.

\section{STRUCTURAL BEAUTIES OF THE EEL.}

I am happy to find that among anglers there is gradually spreading a desire to know much more of the actual structure and physiology of fishes than heretofore, and it always gives me great pleasure, when I have an opportunity, of pointing out any structural peculiarity which exemplifies Paley's argument of the wonderful adaptation of means to ends. In the common eel we have an excellent example of this. The eel, as is well known, will live a long time out of water. This habit is of the greatest service to him, as sometimes it is necessary for him to migrate from place to place by an overland route. To enable him to live out of the water the eel has a most elaborate yet simple form of mechanism, by means of which he is enabled to keep his gills moist even though he is not in the water. It will be observed that immediately, or if not very soon after, an eel is taken out of the water, two great swellings will take place each side of the head, and that if the eel is placed back in the water this swelling will immediately disappear. Let us now take a dead eel; we shall find close to the pectoral fins a slit in the skin which acts as a valve. If we take a probe and pass it through 
this slit we find that it enters a large cavity; next, take a pair of scissors and cut open this cavity, inside we shall find the gills proper. It is this eavity which the eel has the marvellous power of filling with water, and keeping a supply which shall not allow the gill fibres to adhere together, and thence of necessity stop respiration. This cavity is of course made of a large and loose skin-like membrane, which holds the required quantity of water; but in order to enable him to fill and empty this cavity, an elastic yet firm mechanism of some kind is absolutely necessary.

See for yourselves what a beautiful piece of machinery is provided by the Creator. A framework of very delicate bones, each bone connected with its neighbour by an elastic membrane of the consistency of goldbeaters'skin, forms a fan-shaped covering over the gills; its action is very like, if not exactly the same as, the action of an umbrella. When the eel wishes to take in his water-supply he, as it were, opens the umbrella-shaped framework and fills his reservoir ; when he wishes to expel the water he, as it were, closes his umbrella, as his reservoir is no longer required to come into action.

If an eel be taken out of the water and placed on the floor of a room, and left there for some time, it will be seen that he will very soon expand his reservoir. After a time he will be desirous to refill his reservoir; take him up and put his head into a basin, you will see that he will immediately take two or three great gulps so as to re-stock his breathing bags. It is by this beautiful piece of mechanism that the eel is enabled to live so much longer out of water than any other fish; and also, as I have stated before, to shift his quarters when it is desirable to do so. 
There is another point in his structure well worthy of observation-it is the spectacles of the eel. The eel has to live amongst mud, stone, \&c., and if his eyes were not protected, it is reasonable to suppose that its delicate structure would occasionally get wounded.

Over the eye, therefore, we find a wonderful eyeglass. This is formed by the ordinary scale-covered skin of the head, just at the point where it passes over the eye, taking the form of a thin but strong transparent membrane, which affords an admirable guard against any injury occurring to the organs of sight. The eye itself is a very beautiful round ball, the iris black pencilled with tints of a golden hue. If the eyeball be cut in two the lens will immediately pop out, the most lovely little crystal ball, in brilliancy equal, if not superior to, a diamond. The reader should dissect off for himself these curious spectacles of the eel; by drying the skin of the head on a piece of window-glass their structure will at once be seen.

The common snake has a somewhat similar provision, only, whereas he lives on dry land, his spectacles have a firmer and horny consistency. The structure of the snakes' eye-glasses may be easily seen in the shed skin of the snake (and snakes shed their skin frequently during the year). When the snake sheds his skin it is found turned inside out. Thus the transparent eyeprotectors easily become discernible.

A question has often arisen as to whether eels have or have not scales. Again look for yourself. Place a portion of an eelskin on a microscope slide or window-glass, and as it dries you will see quite plainly the scales come into view as the slimy membrane in which they are imbedded gradually dries up. These scales are of an oval shape, somewhat resembling carraway seeds. 
They are arranged in very pretty patterns, much resembling the so-called herring-bone pattern in which ornamental titles are sometimes placed.

The eel also has, strange to say, a heart in his tail. If it is desired to ascertain this fact, it is only necessary to observe the eels which are so frequently sold in the streets covered with sand. When the eel becomes faint. and exhausted, he will begin to play up the lymphatic heart in his tail, the pulsations of which can be seen.

Malacopteri.

\section{THE MURAENA.}

Muranide.

Belongrng to the eel family is one of the rarest visitors to our shores; only one specimen is known to have been taken in Britain. This is the Muræna, common in almost every part of the Mediterranean. The ordinary length is between three and four feet; it is strong and difficult to capture, being fished for with lines. The

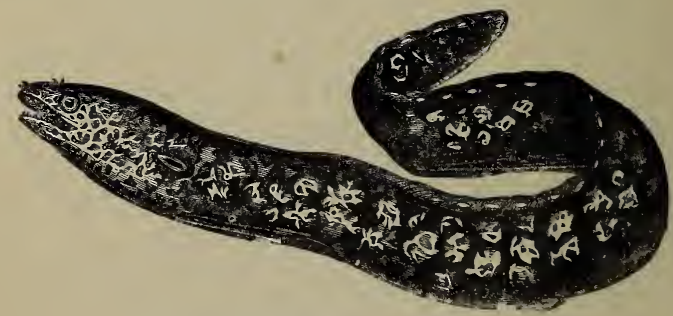

MURENA (MUTCRa Helena).

flesh is said to be delicately white and of very good flavour. It is exceedingly voracious, bites severely, and can live a long time out of water.

In 1869 I received a fine specimen of the Muræna. At first sight it appears much more like an elongated lizard than a fish. Its colour is by no means fish-like, 
inasmuch as the skin shows no scales whatever, and is marked out with round circles touching each other, like the pattern on an oilcloth. The centre of these circles is a dirty yellow, and they are defined one from the other by markings of a chocolate colour ; there are also chocolate spots in the middle of the circles. The circles nearest the head are just the size of a two-shilling piece ; about the middle of the body they are of the size of a shilling; and about the tail of the size of a sixpence. The whole appearance of the fish at a distance reminds one somewhat of a zebra. Strange to say, there is no pectoral fin at all; the entrance to the gill is very small, and surrounded by a black marking; the head, long and narrow, is very like the head of a lizard, especially the head of the iguana; the teeth are numerous, set backwards, transparent, and as sharp as needles, like the dragon's teeth in old statues; a few of them are set in the middle of the palate of the upper jaw.

The specimen weighed 3lbs. 6oz., and measured 3 feet 6 inches. It was sent me in salt from Gibraltar by Mr. Walker, steward of a steamer, and is now in my museum.

The remaining species of the eel family are, the Anglesea Morris (Leptocephalus morrisii), a small ribandshaped fish, of extremely delicate texture, being semi-

Helmichthyi.

Leptocephalida.

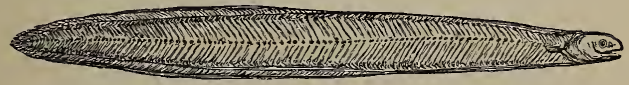

ANGLESEA MORRIS.

transparent. It is about five or six inches long, and in thickness does not exceed the sixteenth part of an incl. It is regarded as a rare visitor; but $\mathrm{Mr}$. Couch says, that 
off the Cornish coast it is taken so frequently that it cannot be uncommon in deep water. It is usually found entangled among sea-weed. The illustration on the previous page is a copy of the figure given of it.

A very rare fish is the Beardless Ophidium, in shape not unlike the red-band fish; the length about three inches.

Apodes.

Ophidide.

BEARDLESS OPHIDIUM (Ophidium imberbe).

Dermopteri.

Amphioxida.

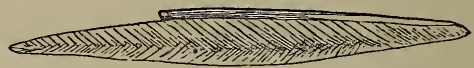

LANCELET (Amphioxus lanceolatus, Branchiostoma lanceolatum).

It has occurred several times in the British seas, and also in the Mediterranean. At first sight it a good deal resembles the Anglesea Morris, particularly in the arrangement of the striated lines on the flattened side. But that animal has a perfect head, though a small one, with jaw, eyes, and gill-covers; while the lancelet has no proper head, nor eye, nor gills, neither has it any fins except one along the back.

Plectognath:

\section{FILE-FISH.}

A single individual of the European File-fish is recorded to have been captured (on the Sussex coast) in 1827. It belongs to a very numerous and important family in the tropical seas, the Balistilla. The fishes belonging to this group are called file-fish, in consequence of the first dorsal fin being studded up the front 
with numerous small projections, which give it a rough, denticulated appearance. The term Balistes refers to another peculiarity in the structure of this and the second spine. The bones or rays of the first dorsal

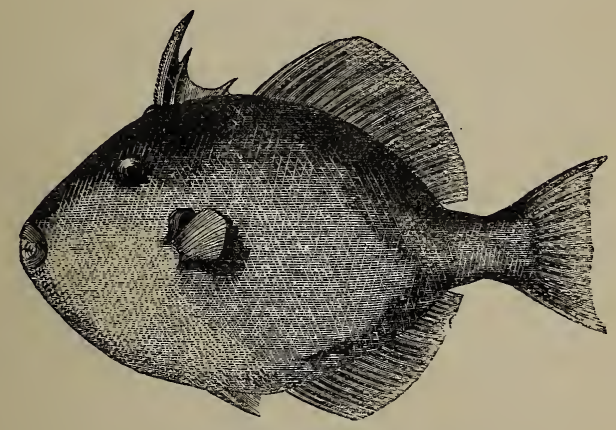

FILE-FISH (Balistes capriscus).

fin are so contrived as to act in concert, with considerable force, in suddenly elevating the fin at the pleasure of the animal. Though the foremost or largest be pressed ever so hard, it will not stir; but if the last or smallest ray of all be pressed but very slightly, the other two immediately fall down with it, as a cross-bow is let off by pulling down the trigger. For this reason the fish is called at Rome "pesce balestra," the latter name having been used by the Romans for an engine of war, constructed on a somewhat similar principle, for throwing darts and arrows. I have shown this wonderful structure to my friend Mr. W. R. Pape, the well-known gun and rifle maker of Newcastleon-Tyne. He was much struck with (I was going to write the ingenuity of ) its conformation, and has promised he will see if he cannot adopt its principle for some of his safety rifle locks. 


\section{GAR-FISH, OR SEA PIKE.}

Pharyngognathi.

Scomberesocida.

(Belone rostrata. Belone vulgaris.)

Local Names: Longnose, Gorebill, Greenback, Greenbone, Guardfish, Gar-pike, Faap, Mackerel, Hornbeak, Hornfish, Mackerelguide, Sea-needle, Old Wife, Whaup fish. German: Der Hornhecht. Danish: Hornfish. Dutch: De Geep. French: L'Orphie.

The Gar-fish, or Sea Pike, alias Mackerel-guide, Greenbone, Sea-needle, or Garrick, appears in shoals about April, and remains till late in autumn. Its length is from eighteen inches to two feet; the jaws are very long, slender, and sharp-pointed, with numbers of small teeth;

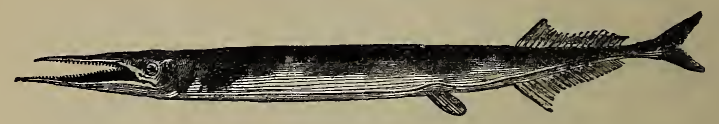

GAR-FISH (Esox belone).

and the body is very slender. On account of its leaving deep water in spring, to spawn near the shore, preceding the mackerel, it has received the name of "mackerelguide." During winter it retires into the unknown depths of the ocean. On many occasions these gorebills are very serviceable as bait.

The late Mr. Couch, writing in Land and Water of December 8, 1866, makes the following valuable remarks :-

"The protruded jaws of the gar-fish (commonly called by fishermen gore-fish) bear some scarcely distant likeness to, at least, the upper jaw of the sword-fish, but being armed with teeth, they are, for the most part, used for laying hold of its prey, until it has an opportunity 
of swallowing it at its leisure; for when an imitative bait is attached to a hook, with the boat under sail, the grasp becomes so firm as to drag the tempting morsel away without the necessity of biting it through. There are instances, however, where something beyond the impulse of appetite moves the fish. In the middle of the summer I received from a skilful and obliging fisherman a mackerel, which, among others, had been taken in a drift-net, and which had a conspicuous wound which penetrated the body near the pectoral fin, clearly showing that it had been inflicted a few days before its capture. This fish was not visibly emaciated, although from the size of the wound and the important parts through which it had penetrated, the injury might be judged to have been of a most formidable nature, and the instrument by which it had been inflicted was still remaining where it was pierced. This was the upper jaw of the gar-fish, which had entered on the one side; it projected on the other side for about the fourth of an inch, at which part the wound was larger, more torn, and bore a much more morbid appearance. The lower jaw of the gar-fish was not in the wound, and there is little doubt it had been withdrawn by the gar-fish; the broken jaw had been broken off close to the forehead. I made the inquiry among the fishermen whether such a case as this was known, and I was informed that a short time previously one of them had caught with a line a gar-fish, in which both the protruded jaws had been broken off close to the head, the cause of which may now be guessed at."

In my museum can be seen a series of gar-pike from the egg up to the adult fish. I have discovered that the eggs are covered with spicula, which have the effect of making them adhere to weeds, \&c. 
The bones of the gar-pike are of a beautiful green colour, but they are not poisonous. I do not know what the colouring matter is, it is not copper. These fish are often plentiful in the London markets; they are very good eating.

Resembling the precedıng species in general appearance, but very much smaller (from a foot to eighteen inches) is the Saury Pike, or Skipper.

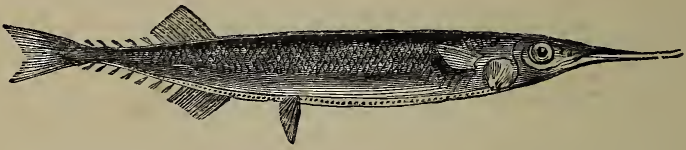

SAURY PIKE (Esox saurus).

In Britain it is a migratory fish, appearing usually in the autumn, in abundance at one time and sparingly or not at all at another. These fish do not swim in deep water; they are rapid in their movements, and in their manners resemble the flying-fish.

\section{GLOBE-FISH.}

Plectognathi.

(Tetrodon Pennantii.)

Diodontida.

This species is remarkable for being provided with the means of suddenly assuming a globular form, by swallowing air, which, passing into the crop, or first stomach, blows up the whole animal like a balloon. The abdominal region being thus rendered the lightest, the body is said to turn over,* and the fish to float upon its back without having the power of directing itself during this state of forced distention. The body is

* I should like to have this statement confirmed. 
usually oblong, and it is only when alarmed that the fish has recourse to this admirable mode of self-defence.

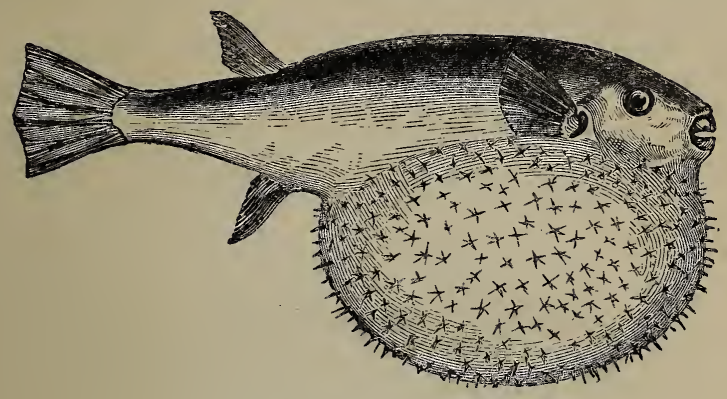

GLOBE-FISE (Tetrodon stellatus).

I hear that in the warm seas, where these fish are found, the local boys, ever up to mischief, make these fellows blow themselves up, and when they are quite tight, they hit them smartly with a stick, and the poor fish explodes with a crack. This may be said to be the pouter pigeon among fish.

Acanthopteri.

\section{GOBIES.}

Coucr figures eleven kinds of gobies: the Paganellus, the yellow goby, the little goby, the two-spotted goby, the broad-finned goby, the spotted goby, the one-spotted goby, the speckled goby, the transparent goby, the slender goby. I would refer my reader to his admirable figures and descriptions.

The Gobies proper, or Sea Gudgeons (German: Meergrundel), are apparently of little value, beyond supplying food for other fishes. They are easily recognised by the peculiar form of the ventral fins, which are united on each side, so as to form a circular funnel-shaped cavity. 
The speckled or spotted goby is not only common on all our sandy shores, where it is constantly taken by the shrimpers, but is also plentiful in the Thames, where it is know by the name of Polewig, or Polly-bait. They delight to bask in shallow pools, where, when motionless, it is difficult to detect them, their backs being precisely the colour of the sand on which they rest.

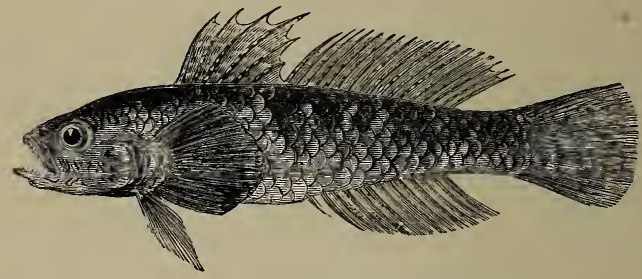

BLACK GOBY, ROCK GOBY (Gobius niger).

In Land and Water, March 20, 1875, Mr. Henry Lee thus describes the Cornish Sucker:-

"I have to note this week the arrival at the Brighton Aquarium, from St. Austell, of twenty-four 'sucking

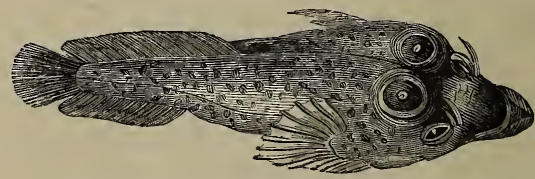

CORNISH SUCKER (Lepadogaster cormubiensis).

fish' of the species known as the 'Cornish sucker' (Lepadogaster gouanii). It is one of the family named by Cuvier the 'Discoboli,' because in some members of it, on the under surface of the body, the united rays of the ventral fins form a flattened disc like the ancient quoit. The middle portion of the disc is flexible, and capable of retraction or the contrary; so that when the 
soft leathery margin is applied to a flat surface, and the central pad drawn inward, a vacuum is produced, and by the 'sucker' the fish adheres to rocks and stones, (generally near to low water mark, amidst the dash and foam of the breakers) and there holds on so firmly that it is not easily dislodged, even by the roughest waves."

Gouan named this species "Le Barbier" and "Le porte Ecuelle."

His simile refers to the resemblance between the sucker and a barber's brass or copper shaving basin.

The Cornish sucker attains to a length of between three and four inches. It is without scales and has a soft though tough skin. The posterior portion of the head is very broad, but it suddenly becomes narrower before the eyes, and is produced into a long-depressed snout, something like a duck's bill. In front of the inner corner of each eye are two flattened cirrhi oi filaments, the longest about one-tenth of an inch, and both of a bright crimson colour, looking very much like the first growth of a young red sea-weed. The sucker differs much in structure from that of the Lump. fish (Cyclopterus lumpus). It consists not of a complete single disc, but of two parts separated from each other, the one being in connection with the ventral, and the other with the pectoral fins. The specimens which I have received varied very much in colouration. But in all, on the back of the head or nape of the neck, are two conspicuous marks, like a pair of eyes. Each of these consists of a large, rather oval spot of deep purple, enclosed within a pale brown ring, and having in the centre a dot or purple of most intense blue, more brilliant than the turquoise. 
The Cornish sucker has been found in the Mediterranean, the Black Sea, and at Madeira, as well as on the south-west coast of England. It deposits its eggs within the shells of oysters, scallops, and other bivalves.

The Unctuous Sucker, or Sea-snail (Cyclopterus liparis), is so called from the soft and slimy texture of its body. It is almost transparent. It is common on many parts of the coast, and especially near the mouths of rivers. The length is from four to six inches; it is of a pale brown colour, irregularly striped with lines of a darker shade, giving it a variegated appearance.

Montagu's Sucker, or the Diminutive Sucking Fish, is a very small species, inhabiting the rocky parts of the coast.

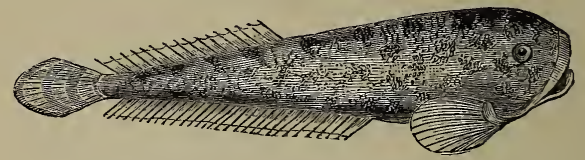

MONTAGU's SUCKer (Cyclopterus MIontagui).

It seldom exceeds three inches in length, and is of a dull orange colour, varied with bluish tints. It is often found under stones. When adhering to any object, it has the habit of curving the tail forward towards the head.

The Bimaculated Sucker (Lepadogaster bimaculatus) resembles the former, but is smaller, and the head more depressed, and the body more tapering. It is so called from two marks on the sides, which, however, are not always obvious. The prevailing colour is a fine red; the under side flesh-coloured. It is obtained in deep dredging, and adheres to stones and old shells.

Allied to the Gobies, and classed with them, are the Dragonets, of which we have two species. The Gemmeous Dragonet, so called from its brilliant gem-like colours. 
The second name, Dragonet, probably originated from its large wing-like fins, and speckled appearance, which induced some naturalists to think the species allied to the flying fishes. It is a handsome fish, with a smooth skin, and having the head singularly striped with blue, on yellowish ground. When just taken its appearance is most beautiful. The first ray of the first dorsal fin

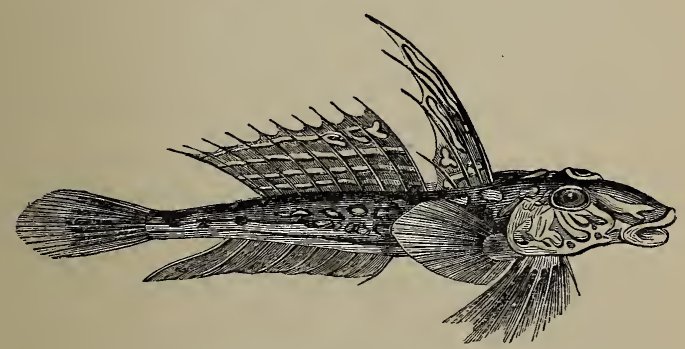

GEMMEOUS DRAGONET (Callionymus lyra), OR YELLOW SKOLPIN.

is very extraordinarily elongated, so as to suggest the resemblance to the strings of a musical instrument. Hence its classical name Lyra. It is not a common fish on our coasts ; it frequents deep waters, and keeps close to the bottom. The length is from ten to twelve inches. Two specimens of this curious little fish were washed ashore at Wick during a gale; one of them being newly killed was very brilliant in its varied colours on being first observed. I have a specimen in my museum caught off Hastings, and kindly presented by Dr. Bowerbank.

The Sordid or Dusky Dragonet (Callionymus dracunculus) is probably so called from its dingy hues, compared with its congener. 


\section{GOLD-FISH.}

Abdominales Malacopterygii.

Cyprinida.

\section{(Cyprinus auratus.)}

Local names: Golden Carp. French : Cyprin dore de la chine. German: Gold-fisch and Silver-fisch. Chinese: Kin-gso Japanese: Kin-jun.

THIs fish originally came from some lakes near the mountains of Tchanghou-the-Kiang. It is said to have been introduced into England in 1611, in the ninth year of the reign of James I. Another story is that it was introduced from China to St. Helena, and thence brought to England in 1728, the second year of the reign of George II. I have searched in vain to find any authority for any of these statements, and should be very much obliged for the information.

I was highly amused, not very long ago, to observe that an artist had painted a scene supposed to have taken place at Pompeii, in which gold-fish were represented as swimming about in a glass globe. How could the inhabitants of Pompeii, in the year A.D. 79, have possibly known anything about China? Gold-fish, as we all know, are now become very common, and I may say that they are the only fish that may be really called domesticated. Through ignorance I am afraid these poor gold-fish are often very cruelly treated by being put in the hot sun, or else allowed to suffer from the cold in winter, and by starvation. Gold-fish should have, if possible, on the top of the water, a layer of duckweed, which should be frequently changed; also a few sprigs of valesneria should be kept at the bottom by being fastened on to a stone. Do not give them bread, as it only fouls the water, but give them scaided vermicelli, and little red worms found in rain-water butts and 
horse-ponds.* These fish vary much in colour. When young they are black or brown; they afterwards become gradually red, also yellow, or spotted with yellow and black, or even white.

Little or no attention has been paid to crossing fish in this country, nor have experiments been made as to the reason of the alteration of their colour. Much has been done with various coloured mice, pigeons, canaries, \&c. Here, then, is a grand field open for experiments with gold-fish. Gold-fish will live and thrive very well in warm water, and would do very well in the reservoirs of water in ordinary greenhouses and vineries.

In Land and Water, May 3, 1879, No. 693, is a most interesting and important account of two gold-fish breeding establishments in Germany and in Austria-the one being conducted by Frei Herr Max von Washington, at Schloss Poels, near Werndorf, in Styria; and the other by Mr. C. Wagner, in the neighbourhood of Oldenburg, and 67, Leipzig Street, Berlin. At Oldenburg there are 120 ponds, covering some $7 \frac{3}{4}$ acres of wet peat land, bordering on the river Hunte. Some of the water is obtained from a hemp-spinning factory. The temperature is sometimes very high, as high as $100^{\circ}$ Fahrenheit. The temperature is kept up by means of steam-pipes from the factory. I commend this idea to many gentlemen who have ponds connected with factories, into which waste steam may be carried. The temperature can be kept up to a high degree by means of an inexpensive arrangement of escape pipes from the engine. The first brood of fish is obtained in March or April, and the second, or even third, between July and September. The stock consists of about 3,000 head. It is much improved by the introduction of Italian and Portuguese

\footnotetext{
* See also Tench.
} 
blood. Mr. Wagner feeds them on an insect dietary, such as blood worms, insect larvæ, and ants' eggs, with clotted blood and barley, also finely-chopped meat, either cooked or raw. The fry born in the spring grow to the size of an inch to two or more inches by the autumn, and are then sold as globe fish. By means of judicious crossing he has obtained many varieties, such as the "telescope fish," the "dolphin head," the "doubletail," and the "Narwhal." They are transported in an oval cask with a perforated bung on the side. The cask is not filled; the splashing of the water aërates it. They are sent long distances, such as to Denmark, Russia, Italy, England, \&c. My friend Mr. Jamrach, the wellknown animal dealer, of 180, St. George's Street, F., often has large consignments of these fish, which, though small, are very handsome and good coloured.

\section{GUDGEON.}

Abdominales Malacopterygii.

Cyprinida.

(Gobeo fluviatilis. Cyprinus gobeo.)

Local name: Googen, Gogone. German: Gründling, Gressling, Krebsfisch. Freneh: Le Goujon. Dutch: Grondell. Italian: Gobione.

To the fishermen living on the banks of the Thames the Gudgeon is one of the most valuable of our British fishes, inasmuch as fishing for the brave little fellow, which gives such excellent sport, is an excuse for many a pleasant outing.

When in the 2nd Life Guards at Windsor I used to devote much of my spare time to gudgeon-fishing in the Thames, and have now in my room a water-colour drawing of the two brothers Reid, the Riding-master and the Adjutant, who were my constant companions in 
gudgeon-fishing. Gudgeon are a true bottom fish, and always swim in shoals. They feed among the weed at the bottom of the river, and more especially on the worms and other insects that lay among the gravel. If good sport is desired in gudgeon-fishing, it is necessary, as old Finmore, the fisherman, used to say, to "lkeep scratching their back," that is to say, a heavy iron rake is thrown out of the punt and the bottom of the river below the swim is well raked. If there are any gudgeons about, they will soon be brought up to the swim by the clouds of mud which float down the river. It frequently

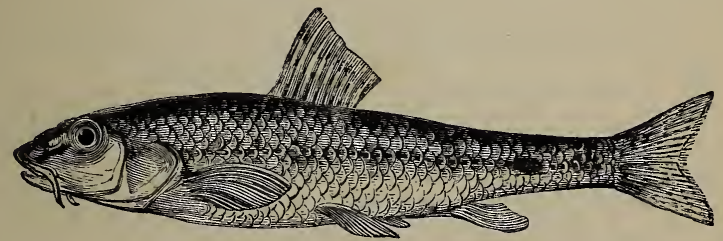

GUDGEON.

happens that one catches all the gudgeons which arrive in answer to the first raking operation. It is therefore necessary, then, to "scratch their backs" again, which, being continued, brings up fresh arrivals. The gudgeon's bite, as shown by the float, is a merry one. All on a sudden you see the float dance again and then dis. appear under water. At that moment strike, and you are nearly sure of your fish. You must be very careful to strike very smartly every time the float arrives at the end of the swim, as sometimes the gudgeon coquettes with the bait, and if you are not quick enough when he is making up his mind you lose him altogether. The gudgeon fisherman has to serve an apprenticeship as to taking the proper depth with the plummet. Unless the worm, which is the best bait, swims exactly right, and 
the line is shot into the exact depth, you will catch no gudgeons, although there may be thousands in the swim. The fisherman who goes out in the punt must not be deprived of his glass of ale for his instructions in these matters.

When out gudgeon-fishing on the Thames, be sure and take a frying-pan, as gudgeons taken out of the water and immediately fried are delicious. Clean, wipe, and flour, then well fry in boiling fat, or, better, in oil, till they are crisp and of a light brown colour. Such a fish dinner is always a great feature in a pic-nic on a fine day.

The habits of the gudgeon are little understood, as some years they are very abundant and other years very searce; and it not unfrequently happens that they disappear from localities where they have been plentiful for years. The cause of this is unknown, and I leave it for our friends, to whom we fish culturists would be exceedingly obliged if the cause of these appearances and disappearances of the gudgeon can, be explained. The gudgeons are said to spawn in the months of April and May, and the French authorities say they require a month to hatch out.

The best months for gudgeon-fishing are August, September, October, and even November. The angler will observe that among his catch some may be very little fish, while others are of three times the size. Here, then, is another difficulty. What is the age of these fish, and to which hatchings do they belong? In the winter the gudgeons go into very deep holes. Favourite spots for them when in the biting humour about Windsor are the deep holes dredged out of the bed of the Thames by the dredging, locally called ballast, barges, from which, by the way, I have often procured, 
when out gudgeon fishing, many fine specimens of what the bargees call "water-bones," i.e., antlers and other bones of the ancient British red deer and roebuck. and where, every now and then, I have procured specimens of Roman swords and other antiquities.

To lawyers the poor innocent gudgeon may be a very serviceable fish, for he may be brought as a witness into court to prove that pollutions are not injurious to salmon or trout fisheries. A live gudgeon is placed, in the presence of the judge and jury, in the polluted water and he does not "turn up," therefore the counsel argues that manufactures or the town sewer are not in fault, as the water allowed to flow into the river is not injurious to fish life. If an expert in fishery matters does not happen to be present, this gudgeon's argument will go down, as the judge and jury probably are not aware that gudgeon are very fond of living in sewerwater as long as it is just running, whereas the same water would be almost immediately fatal to a trout or young salmon. The largest gudgeon I ever caught were in a sewer which ran along the east side of the college meads at Winchester.

Avanthopteri.

\section{GURNARDS.}

Local name: Grey Gurnard. German: Der graue Seehahn. Swedish: Knot. Dutch: Poon. French: Trigle Gournan. Local name: Saphirine Gurnard. German: Die Seeschwalbe or der Knurrhahn. Dutch: De Groote Roode Poon.

The Elleck, Red Fish, Soldier, Red Gurnard, Rotchet (Trigla cuculus), is caught on the west coast of England and Ireland at all seasons ; it is usually about a foot in length; it inhabits moderately deep water, and feeds upon shell-fish, crabs, \&c. ; it takes a bait, and is caught in trawls. 
The Sapphirine Gurnard, or Tub-Fish (Trigla hirundo), or Swallow Gurnard. The name "tub" is derived from a word which signifies short and thick, and of which the word "tubbot," frequently used in the west of England, is the adjective. The fins of the fish are of a most lovely blue; it grows to a large size-as much as 11lbs. In June, 1869, I received from Dr. Norman, of Yarmouth, a very fine specimen of this fish ; it was two feet and one inch in length, said to be the largest ever caught on that coast.

The Piper (Trigla lyra). In November, 1871, $\mathrm{Mr}$. Frank Gosden, of Exeter, presented me with a very handsome specimen of the piper, which is now in my

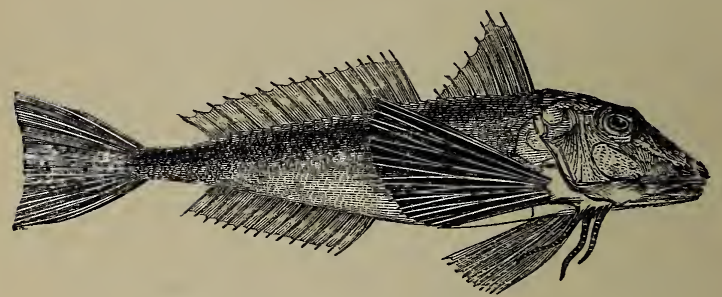

RED GURNARD (Trigla cuculus).

museum. Mr. Couch says the piper is little known in the north of England, and is not numbered among the fishes of Scotland. It is far from rare on the west coast, except in winter, when it seeks deep water; it resembles the tub-fish, but is held in greater estimation for the table. The colours are very brilliant; the head, back, and sides of a pink or scarlet, and nearly white on the belly; the fins more or less red. It is said to obtain its name from being somewhat the shape of an ancient musical instrument, or from the peculiar noise it makes when taken out of the water. 
The Streaked Gurnard, or the Unbearded Mullet (Mullus imbebris, Trigla lineata). It is a rare fish, and has its pectoral fins coloured like the end of the tail of a peacock.

The Grey Gurnard, Gowdie, Hardhead (Cuculus grisens, Trigla gurnardus), Crooner, Croonack. To " croon" meaning in Scotland to make a dull croaking noise. It is a common fish in the British markets, and is caught on the northern coasts of Scotland and Ireland, as well as in the south and west of England. It generally lives at the bottom of the sea, but often ascends to the surface in fine weather in large numbers.

Bloch's Gurnard (Trigla blochii); so called after the naturalist Bloch.

Langthorn Gurnard, Shining Gurnard, Long-finned Captain (Trigla hicerna, Trigla obscura, Trigla milan). The langthorn gurnard is more slender than others of this genus ; it was first discovered by Dr. Parnell, who obtained it from. the Brixham trawlers : they called it the "Iong-finned captain," on account of the length of the two or three first rays of the first dorsal fin. It scarcely reaches a foot in length.

The Little Gurnard (Trigla paciloptera). I have never seen a specimen; it is said to be taken at Wey. mouth.

The head of the gurnard is so armed with bones as to remind one of the appearance of knights in armour. They are also furnished with three rays at the base of each pectoral fin, which help the fish, as organs of touch, to find its food at the bottom.

These three rays are used in a very peculiar manner. In June, 1843, my father, the late Dean of Westminster, read a paper on this subject before the Ashmolean Society at Oxford, which I now quote, as it has never 
yet been made public, except in the proceedings of the Society.

Dr. Buckland made a communication on other modes of locomotion than swimming in the family of fishes, and showed that the fins in certain genera perform the functions of feet and wings. Several fishes of the Lophiida family, or " Fishing frogs," have the fins converted into feet or paddles, by means of which some species have the power of crawling and hopping on sand and mud. The Climbing Perch (Perca or Anabas scandeus) of the Indian rivers is known to live a long time in the air, and to climb up the stems of palm-trees in pursuit of flies by means of spinous projections on its gillcovers. Fishes of the Silurus family have a bony enlargement of the first ray of the pectoral fin, which is also armed with spines, and this organ is not only an offensive and defensive weapon, but may also give ambulatory movements along the bottom of the waters which these fish inhabit. The flyingsfish are notorious examples of the conversion of fins into an organ of movement in the air.

M. Deslongchamps has published, in the "Transactions of the Linnæan Society of Normandy, 1842," an account of his observations on the ambulatory movements of the gurnard (Trigla) at the bottom of the sea. In 1839 he had an opportunity of observing these movements in one of the artificial sea-ponds or fishing-traps surrounded by nets on the shore of Normandy. He saw a score of gurnards closing their fins against their sides like the wings of a fly in repose, and without any movement of their tails walking along the bottom by means of six free rays, three on each pectoral fin, which they placed successively on the ground. They moved rapidly forwards and backwards, to the right and 
left, groping in all directions with these rays as if in search of small crabs; their great heads and bodies seem to throw hardly any weight on these slender rays or feet, being suspended in water, and having their weight further diminished by their swimming-bladder. During these movements the gurnards resembled insects running along the sand. When M. Deslongchamps moved in the water the fish swam away rapidly to the extremity of the pond; when he stood still they resumed their ambulatory movement and came between his legs. On dissection we find these three anterior rays on each pectoral fin to be supported each with strong muscular apparatus to direct their movements, apart from the muscles that are connected with the smaller rays of the pectoral fin.

Dr. Buckland then stated that Miss Potts, of Chester, had sent him a large flagstone from a coal-shaft at Mostyn, bearing impressions which he supposed to be the trackway of some fish crawling along the bottom by means of the anterior rays of its pectoral fins. There were no indications of feet, but only scratches symmetrically disposed on each side of a space that may have been covered by the body of the fish whilst making progress by pressing its fin-bones on the bottom. As yet no footsteps of reptiles or of any animals more highly organised than fishes have been found in strata older than those which belong to the triassic or new red sandstone series, of which the cheirotherium of Germany and Cheshire, and the ornithicnites of Connecticut, are notorious examples. The abundant remains. of fossil fishes armed with strong bony spines, and of other fishes allied to the gurnard, in strata of carboniferous and old red sandstone series, would lead us to expect the frequent occurrence of impressions made by 
the locomotive organs on the bottom of the ancient waters in which they lived. Dr. Buckland proposes to designate these petrified traces or trackways of ancient fishes by the term ichthyopatolites or fish-tracks.

Anacanthini Thoracici.

\section{HADDOCK.}

(Gadus aglefinus.)

German: Der Schellfisch. Danish: Kuller. Iceland: Ise. Dutch: Schelvisch. French : L' Eglefin.

The Haddock is a very valuable commercial fish. It frequents our coasts, from the extreme north to the Land's End, swimming in immense shoals, which seem very uncertain as to their re-appearance in places they have formerly visited. In stormy weather these fish refuse to take any bait, and seek refuge among the seaweeds, in deep waters, until calm be restored. Their food are small fish, herrings' eggs, crabs, brittle stars, \&c.

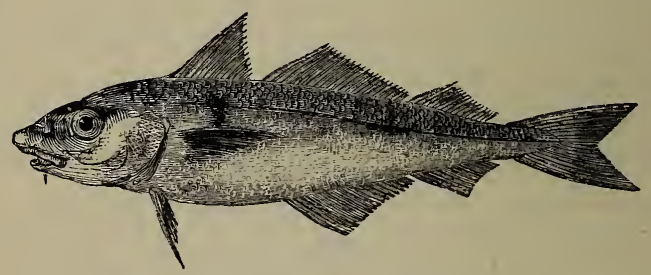

HADDOCI (Morrhua, Gadus cglefinus).

Haddocks are cured by smoking in saw-dust or burning fir branches; and the farfamed Scotch "haddies" come principally from Findon, near Aberdeen.

The common weight of the haddock is from two to four pounds.

The curing of haddock for the London market is 
chiefly carried on by the costermongers on the Surrey side of the river Thames, in the neighbourhood of Camberwell. Mr. J. K. Lord thus writes in Land and Water:- "The tenements generally have a yard at the back, and the description of one will suffice for the majority. Emerging from the passage, I find myself in a small railed enclosure redolent of fish-like perfumes, and ranged around close to the rails are tubs, pans, and I may say vessels of all descriptions, flled with a fluid of a yellow colour and of an oily consistence. This, I am informed, is the 'pickle,' a solution of salt and water. Occupying one corner stands a sort of sentrybox or curing-house. It is composed of scraps of plank, staves of casks, fragments of oil-cloth, and old rags for caulking; numerous ledges are nailed along two of the sides. The haddocks are brought into the enclosure, and girls and boys at once commence removing the heads from the fish, split them open, scrape off all the dirt, and plunge them into the pickling-tubs according to size. The fish soak in the pickle for about three hours, and then the 'skewering up' process commences. The larger haddocks are first, one by one, taken from the tubs, and a peeled rod is passed through each fish until there are as many as the rod will contain; the ends are laid upon the lowermost ledges in rows until filled up, and so on until the smallest are on the top ledges. A fire is kindled upon the ground, which is kept smouldering by the judicious application of sawdust underneath the haddocks. The ' curing-house' is closely shut up, and when the haddocks are sufficiently tinged of a yellow colour they are considered to be cured. From six to eight hours is quite sufficient time to enable a skilled curer to split, salt, and smoke a load of haddocks fit for sale." 
Anacanthin Thoracici.

\section{HAKE.}

Gadida.

\section{(Merlucius vulgaris.)}

German: Meerhecht, merlan: Danish: Kulmule, Norwegian : Berglax. French: Merluche.

IT has an extensive range, being found in the northern seas and in the Mediterranean. It commonly measures nearly two feet in length, but not unfrequently exceeding three. It is of a slender, elongated form; the head large, broad, and flat; the mouth very wide, and armed with very long and sharp teeth, the lower jaw being the longest. Off the Cornish coast, this fish is a constant attendant on the shoals of pilchards. They are a coarse fish; large quantities are annually preserved by salting and drying, part of which are exported to Spain. We frequently see the soundings marked in sea-charts as consistin'g of "Hake's teeth." I am investigating this subject, and it appears that the "Hake's teeth" are really a shell. (See Appendix, p. 384.)

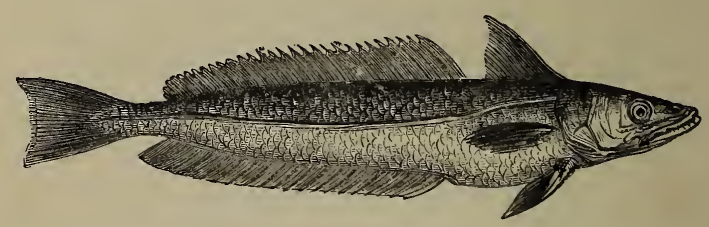

HAKE (Gadus merlucius, Merlucius vulgaris).

An uncommon fish is the Great Forked Beard, or Forked Hake. It is found sometimes off the Cornish shores, where it keeps in deep waters. But little is known of the natural history of this fish. Its appearance is well marked by the long bi-forked cirri on the 
lower part of the head, as well as by the sharp triangular fin on the back, which precedes a second, resembling that of the torsk. Its lengtll is from

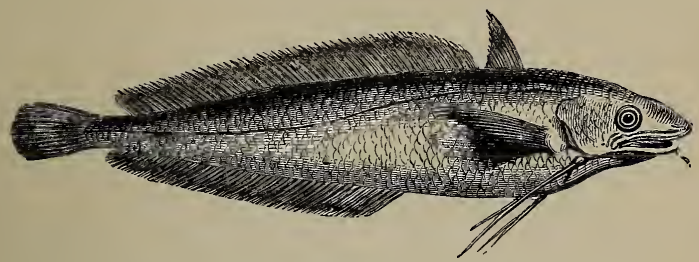

GREAT FORKED HAKE (Physis furcatus, Blennius physis).

eighteen inches to two feet. It is known among fishermen by the name of "Hake's Dame."

The Lesser Forked Beard, called the Tadpole Fish (Raniceps jago, Raniceps trifurcatus, Barbus minor). Its

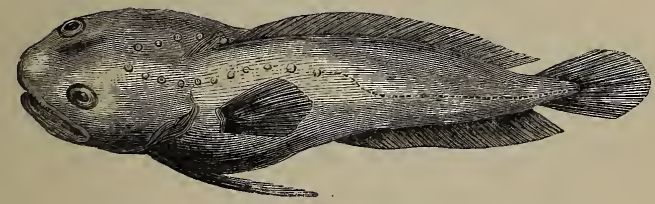

TADPOLE FISH.

singular appearance is well expressed by its name, which refers to the broad, depressed, frog.like head, which, being attached to a rapidly-tapering and compressed body, gives its general form much resemblance to a tadpole. The likeness is still further increased by the colour, which is either very dark brown or black, the folding of the lips only being snow-white. It is one of the rarest British species, and previously known only as an inhabitant of the shores of Cornwall. 


\section{THE HERRING.}

Abdominales Malacopterygii.

Clupeida.

\section{(Clupea harengus.)}

German: Der Haring. Danish: Sild. Norwegian: Straalsild. Swedish : Sill. Dutch: Haring. French: Le Hareng.

On the 1st March, 1879, the Commissioners appointed to inquire into the Herring Fisheries of Scotland presented their report to Parliament through the Home Secretary.

The Commissioners were Frank Buckland, Esq., Spencer Walpole, Esq., and Archibald Young, Esq.

As the Parliamentary Blue Book has not probably been read by the general public, I shall now give an abstract of it:-

"In pursuance of our instructions we held inquiries at the following places, viz.:-On the east coast at Eyemouth, Anstruther, Montrose, Aberdeen, Peterhead, Fraserburgh, Banff, Buckie, Lossiemouth, Burghead, Inverness, Helmsdale, Lybster, and Wick; in the Orkney and Shetland Islands, at Kirkwall and Lerwick; on the west coast and in the western islands, at Stornoway, Tarbert (Harris), Ullapool, Balmacarra, Fort William, Inverary, Crerae, Loch Gair, Ardrishaig, Tarbert (Argyllshire), Campbeltown, Girvan, and Ballantrae. We also sat at Edinburgh, and at Glasgow.

"We received much valuable information and assistance from numerous gentlemen, fishery officers, fishcurers, fish-salesmen, fishermen, and others. We are bound especially to acknowledge the assistance readily afforded to us by the Hon. Bourcrie F. Primrose, the 
Secretary to the Scotch White Herring Fishery Board and his inspectors and officers.

"Herrings are caught off almost every portion of the coasts of Scotland. But the herring fisheries in Scotland do not everywhere commence at the same period.

"The shoals or armies of herrings * appear on the north-west coast of Scotland in the beginning or middle of May. The great fishery in the Minch, the sea between the Long Island and the mainland, is prosecuted from about the middle of May to the beginning of July.

"The fishery on the east coast commences about the middle or the end of July, and continues till the beginning or middle of September.

"On the south-west of Scotland, and in Loch Fyne, the period of the fishery partially coincides with that on the east coast.

"On the Ballantrae bank, off the coast off Ayrshire, the great fishery is in February and March.

"The herrings taken in the Minch in May and June are technically known as 'matties.' They are immature fish, with the milt and roe undeveloped. They are principally sold in the Russian markets, where they are regarded as a delicacy, and the great Russian families are in the habit of obtaining for their own use an early barrel of Scotch matties.

"The great majority of the herrings caught on the east are, on the contrary, spawning or breeding fish. During the latter end of July and the greater part of August they are full of milt and roe. In that condition they command the highest brand given by the White

* The word herring is derived from the Dutch word " Herr," an army. 
Hexring Board, and are classed as 'Crown Fulls.' Late in August the fish deposit their spawn, and are afterwards lnown as 'spent' or 'shotten' herrings. All these brands are purchased by fish curers, and exported viâ Hamburr and Stettin to the great continental markets of Russia, the whole of Germany, and even as far as the Turkish frontier.

"The fish caught in Loch Fyne, like the fish caught on the east coast, are chiefly 'mature' and 'full' fish. They are superior in quality to any other Scotch herrings, and command a market of their own as 'Loch Fyne herrings.' The majority of them are sold fresh, either in Glasgow or some of the great English towns, where, from their size and their flavour, they are held in high estimation.

"The fish taken on the Ballantrae Bank, off the Ayrshire coast, in February and March, are also spawning or spawned fish, and are chi'efly sold in a fresh state. The Ayrshire fishery is the only instance of an extensive fishery for full and spent herrings at that time of the year; the fishery for spawning fish at all other parts of the coast is conducted in the summer or autumn, and not in the winter or spring.

"The west coast fishery for matties in May and June, the east coast fishery in July and August, the Loch Fyne fishery in the summer and autumn, and the winter fishery on the coast of Ayrshire, form the four most important fisheries for herrings in Scotland at the present time. But herrings are caught in other parts of Scotland, and in most of those parts at all times of the year. They are largely used as bait for cod and ling, and for the long lines generally; and their use in this respect is of especial importance."

Those who are interested in the herring fisheries 
should study the evidence given to our Commission, and also our report an analysis of which, as well as the conclusions at which we arrived, is now given.

Conclusions of the Herring Commissioners :-

"1. The herring fishery on the coast of Scotland, as a whole, has increased and is increasing.

"2. Legislation in past periods has had no appreciable effect.

"3. Nothing that man has yet done, and nothing that man is likely to do, has diminished, or is likely to diminish, the general stock of herrings in the sea.

"4. Either from the operations of man, however, or from some other cause, the herrings have been deterred from entering the firths and sea-lochs of Scotland in the same numbers as formerly.

" 5 . The fishery for herrings has in consequence been gradually prosecuted farther and farther from the land, especially on the east coast.

"6. The supply of herrings to the public market has not been injuriously affected by this circumstance.

" 7. It is, therefore, inexpedient either to impose or to continue any restriction on the free action of fishermen with the view of increasing the stock of herrings in the sea.

" 8. It is, consequently, desirable to repeal the sections which nominally impose an annual close season and a law of mesh on the Scotch herring fishermen.

"9. We think it desirable, however, vo continue the prohibition of the use of movable nets and fishing for herrings in Scotland on the Sabbath, but such prohibition should not be accompanied by the heavy penalty which now attaches to its infraction.

"10. As a mere matter of police it is desirable to prohibit the use of trawl nets (seine nets) in the Loch 
Fyne above Otter Spit, and to give the Secretary of State the power to prolibit the use of trawl nets in other narrow waters less than one mile wide.

"11. It is also desirable to prohibit the shooting of any movable net between sunrise and sunset.

"12. We think it likewise desirable to empower the Secretary of State to prohibit the use of a beam-trawl in certain places, though the necessity for such a prohibition has in no particular case been fully established to our satisfaction.

"13. The Sea Birds Preservation Act, protecting gannets and other predaceous birds, which cause a vast annual destruction of herrings, should be repealed in so far as it applies to Scotland."

In the appendix to this report I have written a chapter on the natural history of the herring, in which I have attempted to embody the information given in the evidence as well as my own personal observations relative to the anatomy and physiology, enemies, food, migrations, shoals, spawning, growth, \&c., of this most valuable commercial fish. I have only space for one or two of my remarks.

\section{THE SHOALS OF HERRINGS.}

It seems a special adaptation of Providence that the herrings should be gregarious, and that they should go intuitively and voluntarily in large herds, as we should say in writing about land animals. A herring weighs on an average a little over five ounces; if they were not a gregarious fish they would not be arailable for the food of man, and the capture of them would be difficult and expensive ; but as they are gregarious, vast quantities of good and nutritious food can be captured readily. 
The masses of herrings are sometimes so very great that the nets often sink to the bottom with the immense weight. It is impossible, of course, to tell the exact disposal of the battalions, regiments, companies, and rear and advanced guard of an army of herrings on the march through the waters of the vast ocean.* I have come to the conclusion that the progress of an army of herrings through the water may be illustrated by the observation of a flock of rooks or starlings flying through the air; supposing a net were floated haphazard in the air, on the chance of catching a flock of rooks, the birds might strike the net in a body at the middle of the net, while the portions of the net to the right and left of it would catch only comparatively few birds. So it is with the herrings. If there is no indication of their whereabouts in the sea by the appearance of birds, whales, \&c., $\uparrow$ a fleet of nets is floated haphazard. These fleets of nets vary, according to circumstances, from 1,500 fathoms to 1,800 fathoms, or over two miles in length, from a single boat. In my report on the Norfolk fisheries I give the following statement:- "During the months of September, October, and November, it would be well within the mark to state that there are fishing for herrings every favourable night in the North Sea, between five and six thousand miles of netting."

* These shoals of herrings are called Bouillons (Boilers) or Radeaux (Rafts) by the French fishers. In Loch Fyne a shoal is sometimes called an "Eye." In Norway a shoal is designate? "Sillglotta."

$\dagger$ A fisherman of Yarmouth had been three weeks at sea without a fish, and was anxiously watching his fleet of nets, when suddenly he saw a gull make a sweep at them and fly away with a herring. In almost a minute the whole fleet of nets were floating on the water full of herrings: twelve lasts were caught. 
The nets now used by the Scotch fishermen are made of cotton, which is much more killing than hemr, inasmuch as the herrings cannot see the nets so easily.

Many of the larger herrings are killed by the net, but yet are not brought into the market at all. As the net meets the "shoal" of herrings, the fish that are suitable to the dimensions of the net are masked (a very expressive word) and caught; the larger herrings swimming against the net put their noses into the mesh of the net, and continue to fight so much that they will sometimes push the net on to the surface of the water forward, commit suicide as it were, and then fall out. Thus many herrings fall out that are not used at all. Sometimes half, or even more, get caught by the nose and are drowned, but not masked or gilled. These fish fall out of the net and are lost. A mesh with thirtythree rows to the yard would catch these fish and would allow the young fish to go through. These herrings are caught by a boy in a landing-net, and they become his perquisite. A boy with a skim net will catch one cran out of twenty.

These shoals of herrings are often of enormous extent. Captain McDonald, of the cruiser Vigilant, informed us that, at the end of August, 1877, he fell in with a shoal of herrings in 18 fathoms of water, or 108ft. deep. This shoal extended for four miles. in length along the coast and was two miles broad. In order to get some idea of this shoal of herrings I have scaled out its dimensions on the map of London. Supposing one end of the shoal to be at the Marble Arch on the west, the other end on the east, extending in a straight line, would reach the London Docks beyond the Tower. The width would be from the House of Commons to Euston Square Station. Captain. 
CRAN, BARREL, LAST, AND MAIZE OF HERRINGS. 119

McDonald states that the shoal was a solid mass of herrings. There were far more herrings in this shoal alone than are taken in a year throughout Scotland.

The method of salting herrings, as practised by the Dutch, is said to have been invented, about 1486, by William Beuckel or Beukels, a native of Biervliet, in Flanders, hence the word "pickled" herring. Tlis great benefactor to mankind, a humble but very observant fisherman, may be said to have laid the foundation of the Dutch herring fishery, which afterwards proved to these people a source of great wealth.

\section{MEASUREMENTS OF HERRINGS.}

A cran contains $37 \frac{1}{2}$ imperial gallons, or 800 to 1,000 herrings, according to condition.

A cran of immature herring would contain about 1,000 fish.

A cran full of herrings would contain about 800 fish.

A barrel contains 700 to 1,000 herrings, according to condition.

A last nominally contains 10,000 fish, and 132 herrings are given for every 100 ; therefore at Yarmouth a last representing 10,000 herrings contains in reality 13,200 fish.

A maize or mease contains 500 herrings.

A cran of garvies contains 4,000 fish. A cran of fresh herrings yields a barrel of cured fish: the cran holds more than a barrel, as it contains the herrings afterwards rejected as too small for curing.

During the course of our Herring Inquiry in Scotland my friend and colleague, Mr. Spencer Walpole, made the original observation, that nearly if nct quite all the 
herrings taken in the Scotch fisheries wore exported to Protestant countries (see p. 114), whereas the take of Cornish pilchards were exported to Roman Catholic countries (see p. 165). There must be some good physiological reason for this curious fact.

Dermopteri.

\section{THE SEA LAMPREY.}

\section{(Petromyzon marimus.)}

Petromyzonida.

Local names: Sea Lamprey, Lambereel, Ramper-eel, Spotted Lamprey, Spantier-eel, Say-nay. German: Die Lamprete, See Lamprete, Meerpricke, Wasserunke. Danish: Havlamprete. French : La Lamproie de IIer. Italian: Lamprea marina.

Mr friend Mr. J. K. Lord has embodied in an article in Land and Water, July 13, 1867, the following inform-

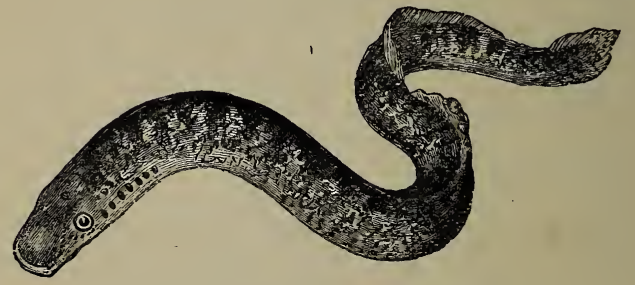

LAMPREY (Petromyzon marinus).

ation on lampreys, and I shall therefore quote it in its integrity.

"The Lamprey belongs to the second order of fishes (Cyclostomata), or in other words, round-mouthed fishes. This order contains only two families-firstly the lampreys, and secondly the group Myxinida; the Myxine glutinosa is well known to fishermen as the 'lag.' The lamprey (Petromyzon, which means stone-sucker) is decidedly an ugly fish and very reptilian in look. It lias a tougl, scaleless, mottled skiu, and is perfectly 
deroid of both pectoral and ventral fins. A long f'eshy fold of the skin runs round the hinder end of the body, but having no true rays it can hardly be called a fin. The skeleton is entirely cartilaginous; there are no ribs or other appendages, and the skull is quite rudimentary. The mouth is a singular affair, not unlike the large end of a funnel, dotted all over with small hook-like teeth. Any living thing caught in this formidable trap would stand but a sorry chance of ever getting out again. The breathing apparatus is extremely curious, and wonderfully adapted to fulfil the purposes fo: which it is intended. Instead of gills, as in ordinary fishes, the breathing organs in lampreys are in the shape of tiny sacs, the inner surfaces of which are thickly covered with a perfect network of blood-vessels. There are seven of these sacs on each side of the fish's body placed near the head, and each sac communicates externally with the water by a separate orifice. In describing these curious breathingholes, Professor Owen says: "When the lamprey is firmly attached, as is commonly the case, to foreign bodies by means of its suctorial mouth, it is obvious that no water can pass by that aperture from the pharynx to the gills; it is therefore alternately received and expelled by the external aperture.' The water, besides gaining admission by these seven canals to the bronclial sacs, is let in by the mouth, if the animal so wills it, or by a round hole observable on the top of the head. This aperture has a direct communication with the pharynx. The habit of the lamprey is to fasten itself firmly to large stones or rocks by its suckerlike mouth, and it is said by some writers that they likewise fix themselves on to the bodies of other fish, and devour them whilst they are alive. This statement we 
must be permitted to doubt; the food of the lamprey is generally believed to consist of aquatic larvæ and molluses.

"This fish is clearly not held in such ligh repute in these days as it was in bygone times, for there are several curious traditions relating to civic feasts in which the lamprey constituted an important dish, as bearing reference to some ancient customs connected with river fisheries. We also learn that King Henry I. came to an untimely end by a too full repast of lamprey; this in no way proves the fish to be unwholesome ; the king probably ate too much. In Germany lampreys are cooked in earthenware jars with vinegar and spices, just in the same manner as pilchards are ' marinated ' or ' potted' in Cornwall, and thus preserved lamprey constitutes an article of export."

Lampreys are considered great delicacies in the London market, and during the London season they may be frequently seen on the slabs of our principal fish merchants. Mr. Fitch, the ever-willing and obliging foreman of my friend Mr. Thos. Grove, fish merchant, Charing Cross, tells me that the season begins soon after the salmon, about March, and ends in July. They principally come from the Severn and the Thames, also from Scotland. Now (June) they are getting in roe; the average size is from one-and-a-half pounds to three pounds; they prefer the middle size of two pounds' weight. They are not in the market in winter.

The lamprey, although he looks a slow mover, is yet a very quick swimmer, and there are a good many in the Loire and Rhone. On the Loire, as at Gloucester, they make them into pies, and they are said to be exceedingly good. Lampreys have an extraordinary vitality when taken out of the water. 
The head and breathing apparatus is well worthy the study of comparative anatomists. The teeth will be found to be simply cones of a horn-like substance, not very firmly attached to a fleshy basis.

By the kindness of a lady living near Worcester, I am enabled to give an excellent receipt for cooking lampreys. "After the lampreys have been cleaned thoroughly in salt and water, rub them over gently with mixed white spices, and let them be twenty-four hours. Then put them to stew quite gently till tender with the moisture that has run from them, and if not sufficient to cover them, add a little beef gravy without seasoning and a glass of port wine when nearly done. The small lamperns are stewed in the same way, after being cleaned in salt and boiling water."

\section{THE LAMPERN.}

\section{(Pctromyкon fluriatilis.)}

Local names: Lampern, Lampron, Nine-eyes, Juneba, Seven-eyes, Stone-grig. German: Neunauge. Northern German : NegenOg. French: La Lamproie de Rivière.

Althovgr this fish is very abundant in our rivers, it is not much used as food, yet there is no finer dish than Lamperns.

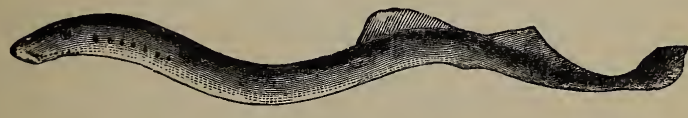

LAMIPERA.

The inhabitants of Worcester often complain to me that they cannot get lamperns to stew; the fact is they 
are much more valuable as bait, and a considerable number are exported from the Severn to the fishing ports on the east coast of England. They are the best possible bait for cod. Large quantities of lamperns are also caught in the Trent. In my Salmon Fishery Report, 1878, I give the following information relative to the lampern fishery in the Trent: "A considerable trade exists on the Trent in the supply of lamperns, which are used as bait for the deep-sea fishermen; as many as 3,000 have been taken in one night at Newark, and 5,000 have been taken at the same place in three days. The lampern fishery begins at the end of August and goes on till March. The fish are sent alive in wicker baskets to Great Grimsby and other ports, but it is necessary that a man should go with them and keep stirring them all the time." The Dutch fishermen are much more clever in handling these baits than the Englishmen. The greatest proportion of Thames lampern are usually consigned to them. I strongly urge all river fishery proprietors to catch all the lamperns they can, and dispose of them as bait for the deep-sea fishing. The merchants at Grimsby, Hull, Scarborough, \&c., will be glad to take them.

\section{SAND PRIDE.}

(Petromyzon branchialis. Ammocotes branchialis.)

Local names: Pride, Sand-pride, Sand prey. Blue Lamprey, IIud-Lamprey, Sand-lurlier, Stone-grig. German: Die Ullle. French: Le Lamprillon.

THis little fish is very like the lampern, and seldom exceeds eight inches long, and girth about the size of a tobacco pipe; by some it is said to be the young of Petromyzon planeri, planer's lamprey. 
Acanthop'cri.

LUMP SUCKER.

(Cyclopterus lumpus.)

Gobiesocide

Local names: Cock-paddle, Blue Lump, Pattle-hush, Red-lump, Sea Owl, Stone-clagger. German: Der Seebulle, Der Seehase. French: Le gras Mollet. Dutch: Snotdolf. Danish: Havpaddle, Steenbider.

THe Lump-fish is common on our own coasts during the spring, when it approaches the shore to deposit its spawn. The male fish is smaller than the female, and at the breeding season, in March and April, becomes very gaudy in hue, the colours combining various shades of blue, purple, and rich orange-red. It is often seen at this time in the shops of the London fishmongers, swinging in the wind by means of a string, attracting attention from its form and brilliant tints. In March, 1870, my friend Mr. John Keast Lord tells me he lately saw a specimen hanging in a shop at Billingsgate. Upon it was the following inscription, written in great letters, "King-fish from Japan." He asked the owner why he put up such an absurd label, and the man told him he was so bothered by persons asking the name of the fish, and that one name was as good as another to nime out of ten who wanted to know. He must call it something, so he named it "King-fish from Japan;" but he knew perfectly well it was only a "jolly old lump sucker." So great is the difference between specimens, that our fishermen consider them to be different species, and call them the Red Lump and the Biue Lump; but the difference in colour and flavour is only the effect of the season.

In February, 1880, I received from Mr. R. B. Norman, of Collingwood House, Yarmouth, a specimen of the largest lump-fish I ever saw. He weighed 11lbs, 
total length 20in., and greatest depth 12in. The eggs were considerably developed, and arranged in curious fimbriated masses, not unlike the disposition of the ova under the tail of the lobster. The entire mass weighed $1 \frac{1}{2} \mathrm{lbs}$, and the total number of eggs by calculation was 194,112. I have made casts of both the lump-fish and her eggs, and they form a valuable addition to my museum. Though an awkward-built fish, it is a good swimmer. The tail is the propelling power, and the fish moves it with great velocity and an action not unlike a clumsy woman running. The apparatus for holding on to the rocks, which is fashioned somewhat like a boy's leathern sucker, is a most curious provision of nature, and shows a wonderful design. The lump-fish carries his anchor close under his chin. The clusters of eggs are generally deposited around a stick or pole, and there are holes in the mass, but whether these holes always represent the places where the piles fitted in I am not quite certain.

Mr. Bowerbank, of St. Leonard's, kindly sent me a still larger lump-fish, weighing $11 \frac{1}{2}$ lbs.; the sucker in this specimen was two to three-quarter inches in diameter, and had most delicate fringe-like edgings. Even after death this sucker retained its powers; for after casting the fish and having cut out the sucker, leaving the thick side bones under the gills, as it were for handles, and having wetted the window-sill, I placed the sucker flat on it; and it was just as much as I could do to pull it off, but with any side movement there was not the slightest resistance. 
Asanthini.

\section{THE LING.}

\section{(Lota molva.)}

Gadida.

German: Dər Leng. Danish : Lange. Dutch : De Leng. French: Molve.

Is March, 1857, I received a Ling weighing 46lbs., and measuring $4 \mathrm{ft}$. 10in. in length. A cast of this fish is in my museum. As an article of commerce the ling is well known, especially in Scotland, where in some parts it forms the staple trade of the inhabitants residing near the sea. It appears, by that most valuable volume, the "Sea Fisheries Report, 1861," that the best cod and ling fishing in Scotland is at Shetland. The fishing for ling is carried out in open boats, a somewhat remarkable circumstance, as from this cause the fishing cannot be carried on in bad weather, and hence a great

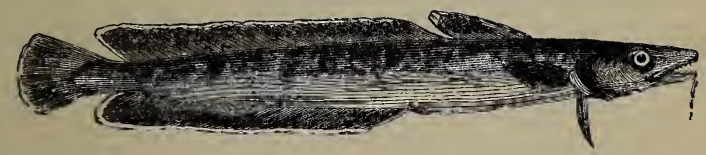

LING (Lota molva, Gadus molva, Molva vulgaris).

loss to the poor fishermen. One witness states it to be the fact that a great deal more of this valuable food might be obtained if more money were spent in procuring better boats. There is also another cause which prevents at times the fishing for ling, viz., the want of bait, which is composed of pieces of haddock, herring, and mackerel, and when these are not procurable from close seasons, and other unavoidable causes, the fishing of necessity suffers.

There are more men employed in this fishery than in fishing for cod, both of which fishing are carried on by 
hand-lines and long lines, and the time of the year is from May until August; some are, however, cauglit in winter, as witness the specimen reforred to above. The ling is generally treated in the same way as the cod when caught, being split from head to tail, salted in brine, washed and dried, after which it is sent to London, Liverpool, and elsewhere, for home consumption; and a great quantity-which always appears to be the case with cheap valuable food-is exported, some to Spain, and some even as far as Australia. If this fish is so much thought of as an article of food 16,000 miles from home, my readers must think with me that it is worth knowing more about in its native parts, especially among the labouring classes.

The ling is very little seen in London, being confined mostly to such places as the New Cut, Lambeth, where it is sold out at threepence per pound to the poor (chiefly Irish) who abound in that neighbourhood. It is surprising the prejudice there is entertained by the English respecting anything cheap; but in the case of the ling cheapness is really combined with goodness.

The ling is met with in a fresh state in the northern counties of England; there it is much esteemed as an article of food. I have frequently met with it in Yorkshire, where it is generally sold at from fourrence to sixpence per pound. The liver of this fish is remarkable for several reasons-the weight being generally large; in my specimen, which weighed 461bs., the liver weighed 3lb. $7 \mathrm{oz}$. Mr. Couch tells us that quantities of oil extracted from the liver " are used by the poor to burn in their lamps, and has been found effectual in severe cases of rheumatics when taken in small beer, in doses of from half-an-once to an ounce and a half. Formerly from fifty to sixty gallons of this oil and that 
of the cod were used at one establishment for this purpose."

The liver is also considered by some persons as a great dainty, and a piece is always, where ling is sold fresh, given to the purchaser for the purpose of frying the fish with, thus being a great desideratum in household economy. The flesh of this fish is remarkably nice eating, resembling much in its firm texture the flesh of the turbot. When used in its salted state some time is required for it to soak in cold water before it becomes palatable. At Stornaway, in the Hebrides, we find as much as 800 tons to be taken in one season; and the price per ton being $£ 20$, gives at this place alone $£ 16,000$.

The fishing appears to have increased of late years cwing to better tackle being used; and after a time, when the boats are improved also, and the men are able to follow the fishing to greater advantage, combined with the facilities which the railways now offer for the carriage of fish, I hope to welcome this most valuable fish frequently in London.

Mr. Reed, of Wick, writes in March, 1872: "I saw landed at our harbour a large take of cod and ling; one of the latter, measuring about six feet, could not have weighed less than sixty pounds. After it was opened to be cured, it was found to contain a salmon measuring two feet three inches, and in pretty good preservation, at the same time showing that salmon go far out to sea, the fishing being about eight miles from land." 
Abdominales Malacopterygr.

Acanthopsida.

Local names: Beardie, Bearded Loach, Loche, Groundling, Lee Loach, Spined Loche, Ground Gudgeon, Loach, Loch Loche. Stone Loach, Tommy Loach, Tommy Loych, Tommy Lurcher, French: Loche, Frauche. German: Steinbeisser, Schmerlein Grundling. Italian: Barbatello.

IT is not uncommon in our rivers and brooks. From its slimy smoothness and activity it is very difficult to

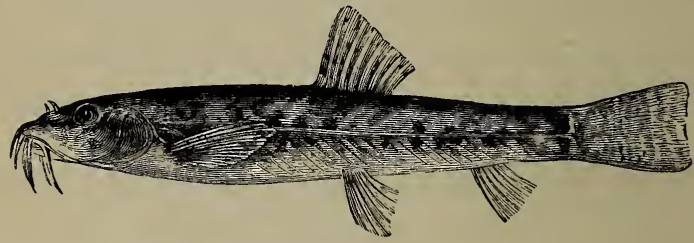

LOACH.

catch. We Winchester boys used to spear this fish on the Itchen with an ordinary fork tied on to the end of a stick, and then pickle him with the minnows. It forms an excellent bait for eels, and Mr. Thames Trout will sometimes take him, if he is properly and artistically spun.

The loach is a veritable hermit; he lives in brooks and small streams, and always under the stones. If the loach risks the end of his nose beyond his hidingplace, it is only immediately to go back again, or to seek another place. The loach is probably nocturnal in its habits. He grows to be about as big as a gudgeon. He is very quick in his movements when frightened, and lives probably on little insects and other creatures found among the moss and weeds of the brooks. Their great enemy is probably eels. 
Nothing whatever is known of their spawning time. I should be too pleased to have any remarks on this subject.

Acanthopteri.

\section{MACKEREL.}

(Scomber scomber.)

Scombrida.

German: Makrele. Danish : Makrel. Norwegian: Spir. Dutch: Makrell. French: Maquereau.

I now give an abstract of my natural history of the Mackerel, published in the "Appendix to the Sea Fisheries Report, 1879 ":-

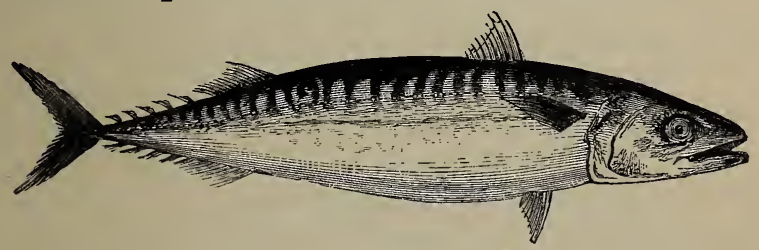

MACKEREL.

"The mackerel first appear in deep water, south and south-west of the British Islands, and are sometimes caught as early as January at the west of Scilly, but the general Cornish fishery does not usually begin till towards the end of February, and extends into June. May, June, and July are the months when drift-net fishing is carried on further up the channel. In July mackerel are generally plentiful. They go on through August and September.

"There is a considerable mackerel fishery at Brighton where they are caught in seines and drift-nets. The fishery generally begins about May. In former times the Brighton mackerel and other fish were sent to London by express fish vans. There is a sale for mackerel all the year round at Brighton; the seine- 
nets are, however, blamed for destroying many small mackerel. These seines are used from Shoreham harbour on the west to Seaford on the east, about fifteen miles.

"At Rye, in Sussex, there is a very large mackerel fishery. The mackerel here are caught in large fixed nets, called kettle nets; hence, probably, the phrase, 'What a pretty kettle of fish!' Each net is a little over half a mile long. The poles on which the nets are fixed are twelve feet high. There are three chambers or bights connected with each straight piece of net. The kettle nets are set on the 14th April, and taken up at the end of November.

"The catch of mackerel varies much. Sometimes as much as 1,000 boxes (50 mackerel to each box) are caught in one net at one tide. The railway authorities give every facility for running expresses to London when a large catch of mackerel is taken. One hundred tons of mackerel were sent to London from Rye Station in one night in June, 1877.

"There are also mackerel fisheries at Weymouth, and many other places on the south coast.

"For some reason or other the mackerel are said to have forsaken the neighbourhood of Yarmouth and Lowestoft, where they were formerly so abundant in the months of May, June, and July."

Mr. Matthias Dunn remarks, "That mackerel spawn in May and June; when first shed it floats on the water. I have taken it from the parent fish when alive. Young ones are about four inches long in August, and about a quarter of an ounce in weight; their rate of growth varies from summer to summer as they find food, or as some summers are more abundant in food than others. In the past August, September, and October they in- 
creased in size at the rate of one inch in length and one ounce and a half in weight per month.'

\section{SCAD, OR HORSE MACKEREL.}

(Scomber trachurus.)

German: Der Stocker. Danish: Hestmakrel. French : Le Saurel. The Scad, or Horse Mackerel, is rather smaller in size than the common mackerel. Its name, therefore, is

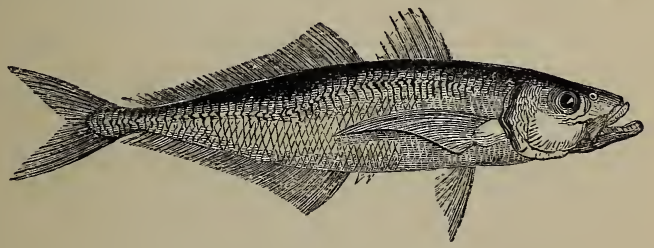

SCAD, OR HORSE MACKEREL.

not derived from its size, but from the supposed coarseness of its flesh. It is occasionally abundant on various parts of the English coasts, particularly Cornwall and

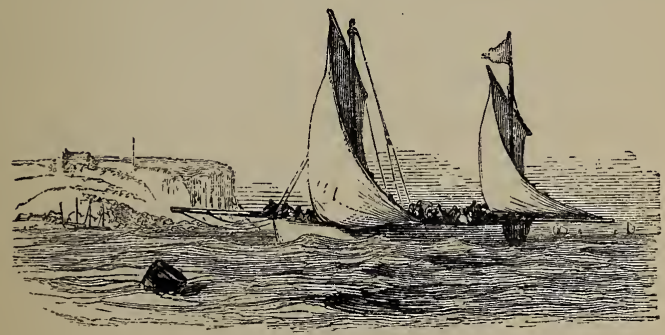

MACKEREL BOATS.

Devon. The usual habit of this fish is to keep near the ground; but when they are in shoals, and pursuing some favourite food, they are said sometimes to become so eager as to thrust each other in heaps on the land. 
A very beautiful specimen was sent me of this fish by Alexander Miller, Esq., of Chepstow Salmon Fishery. It was full of roe. For a considerable distance along the lateral line from the tail it is remarkable as having on each side a row of spines, of a dagger shape, and which fall backwards, each of which forms a sharp lancet of a very hard transparent horn-like substance.

Belonging to the same genus is the Mackerel Midge (Ciliata glauca, Motella glauca, Couchia glauca), so called among the fishermen, as descriptive of its colour and very minute size. It is the smallest fish with which I am acquainted.

In June, 1872, I received from Mr. Matthias Dunn, of Mevagissey, specimens of this interesting little fish. He writes :-

"It is many years ago since such quantities of mackerel midges (Couchia minon) were known to be on our coasts as are now to be seen there. They may be easily discovered on any calm morning, rippling the surface of the sea like grains of sand scattered from the hand. Bass and mackerel are making short work with these little innocents. The recovery of mackerel, after spawning, to their usual plump and firm condition, when feeding on this diet, is marvellous."

Acanthopteri.

\section{MAIGRE.}

(Sciana aquila.)

Scianada.

The Maigre is a rare fish. I have been fortunate enough, nevertheless, to have had the opportunity of examining nine specimens. During 1866 I recorded the capture of no less than six specimens. In fact, I generally get one a-year. The Latin names of this fish 
are Sciana aquila and Sciana umbra. Probably the former word is derived from stica, a ghost or shadow, an idea which its second name, umbra, seems to confirm; but why this should be I cannot understand. It is also called the Ovis marina, or Sea-sheep.

I now give my notes of the colouring of this fish from a specimen examined at Mr. Grove's, in Bond Street : colour of the body generally of a rich bronzed yellow, with tints of gold; light green in front of first dorsal

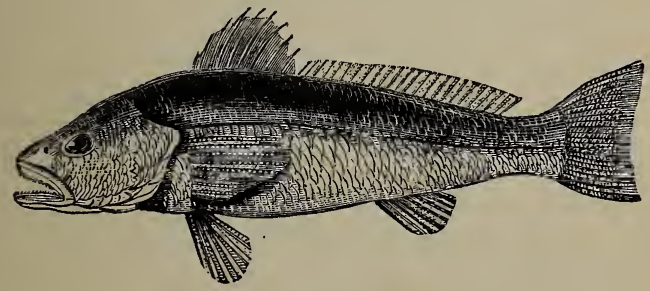

RIAIGRE.

fin, and part of the head; also over the eye light tints of gold, verging into silver on the cheeks; first dorsal fin, pink-red; pectoral, purple; second dorsal, pink; purple ventrals; and anal a neutral tint ; caudal, dark, with red tint.

In the head are found (so the old authors say) two stones of great medicinal virtue as a cure for colic. It is said to live among rocks covered with weeds, a kind of sea-wolf in a submarine forest. Its shape and swimming tail would adapt it to swim with grace and ease in and out of the gigantic sea-weeds. Its body is formed on very graceful lines, like those of fast ocean steamers.

In August, 1867, a fine specimen of the Sciana aquila was taken at Hastings, measuring 3 feet.* In Sep-

* See Land and Water, vol. vi. p. 121. 
tember, 1868, my colleague, Spencer Walpole, Esq., sent me a splendid specimen, caught by the coxswain of the Ipswich lifeboat off Thorpe, in Suffolk. Mr. Walpole wrote: "The fish, I think you will allow, is a fine example, and its colour, I am told, was on its first appearance so brilliant as to justify all that has been written of the splendour of the appearance of the maigre. Its weight was $84 \mathrm{lbs}$., or $28 \mathrm{lbs}$. more than the example described by Mr. Couch, and 12lbs. more than the one described by Nilsson, and also referred to by Couch." The maigre is a tolerably frequent visitor to the channel, but a much rarer visitor to the North Sea. Two fine casts of this wanderer from the Mediterranean are in my museum at the Horticultural Gardens.

In December, 1868, a maigre was taken at Brighton, measuring $5 \mathrm{ft}$., and weighing $70 \mathrm{lbs}$. It was bought by Richard Peek, Esq., M.P., from a man who had found it floundering about in the shallow water. Mr. Peek had it divided, and sent portions to his friends. It resembled the flavour of something between a sturgeon and salmon.

The maigre is said to be able to make a noise under water. This has been described as grunting, or purring. On placing my hand and arm down the throat of a maigre, I discovered that the inner side of every gill-arch was studded with little pyramid-shaped projections, placed alternately, so that they would lock into. each other like two combs. On drying and examining a specimen of these under a glass, I find that this roughness is caused by a vast number of very minute needlepointed teeth, set as close together as the hooks on a teazle-head. There are also two sets of teeth (very much in the shape of a sheep's lidney) on the upper 
surface of the œsophagus. This plateau of œsophagal weapons is composed of teeth, some long and pointed, others very minute, feeling like sand-paper to the touch. The idea struck me that these teeth in the gullet might possibly be the instruments by which the fish produces his purring noise. Upon causing the room to be kept. perfectly quiet, and grating them together, a noise was produced, reminding one forcibly of a mouse gnawing at a board; but most probably the fish in life could sing his own song better than we could, and I believe his teeth are musical instruments.

By chiselling away the lower portion of the braincavity, the ear-bones-the cholic-stones of the ancients -can be discovered. When these ear-bones are held up to the light, they are a lovely white mixed with an opal tint. In outline they are very much like the head of the Egyptian Sphinx, and a few touches of the pencil will make them exactly like the Sphinx.

Abdominales Malacopterygii.

\section{MINNOW.}

\section{(Cyprinus phoxinus. Leuciscus phoxinus.)}

Local names: Baggie, Baggit Banny, Jack-barrel, Jack-Sharp, Meaker, MLeugy, Mennam, Mennad, Mennard, Mennot, Mennous, Menuse, Minim, Minnis, Minnon, Minnow, Mince, Peer, Peuk, Pink, Shadbrid. French: Veron. German: Die Elritze Pfrille Maigrase, Rumpfen, and no less than twentyfive other names. Danish: Elritse. Italian: Sanguinerola.

THe Minnow, though small, is a regular dandy, and during his courting season is got up in the most gorgeous style of uniform. Ladies who are clever with the paint brush will find a novel and most resplendent model in the minnow, but he will not keep his beautiful colours very long. 
The minnow is a very particular fish about the water in which he lives; it must be clear and rapid. He is a vegetable feeder, and also eats insects and worms. The minnows in the Itchen, at and about Winchester College, are very handsome fish, and thrive very well in this chalk water. The abundance of minnows is one reason why the trout are so good. We boys at Winchester never fished for minnows with rod and line, but a net called a minnow net. This net may be thus described: a fine-meshed net is fastened nearly flat to an iron hoop about $\mathbf{2}$ feet in diameter, in the middle is fastened a perforated bullet and a piece of red cloth ; three strings run off from the ring and join together about 2 feet away from the hoop; a longer line is attached to this and also to a pole, say 8 feet long. The net is dropped into the river, the minnows are attracted by the red cloth and the net is raised quickly by means of the pole. Glass bottles used as traps for catching minnows have been invented, and are to be bought at the fishing-tackle shops. This mode of quasi-incipient sport is a capital plan to enter, as masters of foxhounds have it in speaking of their young hounds, the noble sport of fishing. Minnows are not at all bad eating; they are very good simply fried as whitebait, or else pickled.

It appears that William of Wykeham, founder of Winchester College, was accustomed to have minnows served at his table. Thus at a dinner which the bishop gave on Tuesday, Sept. 16, 1394, to the King and Queen, 210 guests were present, the dinner costing $£ 385$ of our present money. Many kinds of fish were served, and no less than 7 gallons of minnows, costing eleven shillings and eightpence. I should not be surprised if these minnows acted as the whitebait of the period.

In the report of the Imperial Society of Acclimatisa. 
tion, 1867, vol. iv. p. 719, is a very able paper on the minnow by M. Saubadon, who breeds large quantities of them for food crevette, trout, and young salmon. M. Saubadon breeds them artificially thus. The minnows spawn on fine days at the end of April or in May, and always on the same piece of ground. They assemble on the spawning ground in vast numbers. The minnows, having been caught quickly with the net, must be taken, the fernale in one hand and the male in the other. By a slight pressure the eggs and the milt will then come out of the fish; the water then must be gently stirred with a feather. In fact, the operation of impregnating the minnow's egg artificially is the same as that for salmon eggs. The eggs when properly fertilised should be hatched out in boxes, as used for salmon eggs, or else placed in a box perforated with holes, and placed in a running stream, so that the water should flow gently through the box. M. Saubadon tells us that a more simple way of getting minnows' eggs is to search the spawning beds of the minnows after they have done spawning. It is a mistake to suppose that these eggs are disseminated and washed away by the current among the gravel and stones.

He says that the eggs, which are very small, will be found sticking adherent one to the other in the interstices of the stones, and that sometimes one finds masses from about 2 inches in width and 8 inches in length.

On May 30th he collected from off the minnows' spawning beds at least six pounds of minnows' eggs. He has no hesitation in robbing the minnows' nests, as these eggs have many enemies, especially eels, ducks, and shore-rats, who quickly find out the minnows' nests, and clear out all the eggs. This process of breeding 
minnows artificially will be of the greatest possible service to our friends who are rearing salmon and trout fry, as the young minnows, as they are hatched out, will form a most valuable and nutritious food to the young salmonidæ.

Plagiostomi Squala.

\section{MONK-FISH.}

(Squatinu angelus.)

Squatinada.

Local names: Angel-fish, Monk-fish, Shark-ray, Kingston. German: Der Engelhai, or Meerangel. French: Pange. Italian: Squadrolino pellenera.

Mr. DE CAUx, fish salesman, Great Yarmouth, was kind enough, in August, 1880, to send me a magnificent

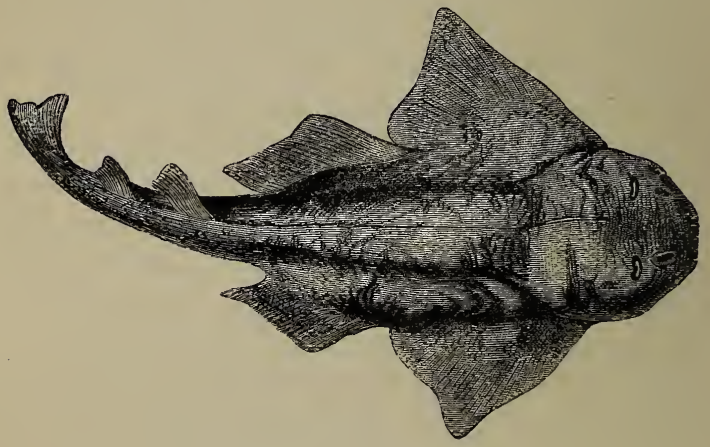

MONK-FISH, OR ANGEL FISH.

specimen of a monk-fish, trawled up by a fishing smack in the North Sea. The fishermen wanted it for an exhibition, but Mr. de Caux was good enough to send it up without having the intestines removed. This fish measured five feet from nose to end of tail, his width at the widest part three feet, and its weight between fifty and sixty pounds. This is the largest specimen I have ever seen. 
The stomach contained nothing, but in the abdomen wero several eggs with soft skin like crocodiles' eggs. In former times these eggs were dried and used medicinally in the pharmacopœia. The skin was powdered and given in cases of itch and psoriasis.

The most extraordinary fact about this sea monster is a very strong and peculiar smell of ammonia. I do not know of any fish that has this strong odour so strongly marked.

In 1875 there was a very fine monk-fish alive at the Southport Aquarium, and I wrote the following account:-

"The jolly old monk-fish that our friend Parry Evans caught in his royal weir at Ilandudno, is in the tank with the sturgeon; this sulky monk-fish always sits at the bottom of the tank, looking like the plaintiff. As the sturgeon swam over the monk-fish he hit him across the face with his tail ; this made the old monkfish jump up and scuttle about."

The angel-fish is found in the North Sea, the British Channel, the Mediterranean, and smaller specimens than the above are not uncommon. It is taken on the "long lines" which are set for ray, \&c. It is not good eating, but the rough skin is used in the arts for swordhandles and instrument cases. It is a great enemy of all kinds of flat-fish, and buries itself in ambuscade in the sand, of which it has the power of taking the exact hue. It is said to stir up the sand with its wings, and when the sand-worms are disturbed, and the smaller fishes come to eat them, the monk-fish suddenly jumps from his ambuscade and devours them. It is cornmon on the bays of Arcachon, and, I believe, on the sandy banks all along the Bay of Biscay. They are frequently seen in the markets of Dieppe, and are not 
uncommon at Brighton and Hastings. The name angelfish is given them on account of the fins on each side of the body, which are very large and very flexible. I expect the name angel was given in old Roman Catholic times, as its wings somewhat resemble the wings of an angel, as we see represented by old masters in pictures or glass windows of foreign cathedrals and churches. Mr. Searle made a cast of this grand fish for the museum, where I have also another specimen, but not so big.

Acanthopteri.

\section{MULLET, RED AND GRAY.}

\section{(Mugilida and Gobioida.)}

Mugilida.

Mullets (Mugil capito). These fish are not frequently captured in the deep sea, but are fishes of the shore, seeking shallow creeks, where they have been captured in vast quantities. They have scarcely any offensive weapons : their teeth being small and delicate, often almost imperceptible ; and hence, notwithstanding their size, they can scarcely attack any other fish, though

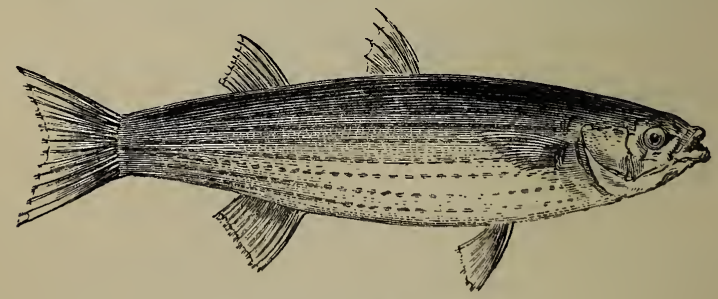

GREY MULLET (Mugil capito).

liable to the assaults of many enemies. They are, however, gifted with a remarkable instinct which aids them in their efforts to escape danger.

Only three species are known as British, of which the Grey Mullet is the most common. The usual size of 
the grey mullet is about fifteen inches, but it sometimes reaches two feet in length. The colour of the back is steel grey, with bluish-yellow reflections. The belly is silvery white, and on the sides there are six or eight lines of a rosy brown. It never goes far away from land, but delights in shallow water. In the summertime it may be seen prowling about on the muddy bottoms of rivers and harbours, with its mouth close to the ground, in search of food. It selects what is soft and fat - is the only fish which usually takes nothing that has life, although occasionally it may swallow worms. Instead of devouring anything, it sucks it away in fragments; hence it is very rarely taken with the hook. It ventures to some distance up rivers, returning with the tide. The mullet is taken in considerable numbers more especially on the Hampshire, Sussex, and Devonshire coasts, and is held in great esteem as a delicacy. The best method of taking them with a bait is by rod and line, baited with a red worm called the rag-worm; they may be also taken in any number by the artificial fly. As regards the bait for mullet, a gentleman at Margate writes me:-

"I have been to Grove Ferry, and seen Stephen Brown. He again said the slimy stuff which rises more freely after drought from the bed of the river will stick to the hook, and that there is no other bait equal to it for mullet in the Stour. Mr. Buig, the landlord of the inn, also states the mullet caught in the Stour are generally full of this brown slime."

Both this and the Thick-Lipped-Mullet (which is gregarious and smaller than the other) have a remarkable habit of escaping from capture by leaping over the net. Mr. Couch has described very strikingly their mode of proceeding: "The usual way of taking the mullets is by 
enclosing them in a seine, and then drawing them on shore. As soon, however, as they find themselves enclosed, they seem confused, and wander from one part of the net to another, seeking a means of escape. Order is, as if by mutual consent, very soon established, and the largest of the shoal generally takes the lead in every subsequent proceeding. Thus guided, every portion of the net is carefully examined, and if a hole be found, through it they all make their escape. If unsuccessful in this, they attempt to lift the foot of the net, but the trial always fails, and many are meshed in the attempt. They retire to the centre of the space enclosed by the net, and, after a short time, the leader rises swiftly to the corks, and, followed by all the others, throws itself into the water beyond, and thus they effect their escape. The fishermen have had recourse to a stratagem which usually succeeds. They scatter straw along the inner margin of the buoys, and the fish, deceived by this, throw themselves over the edge of the straw, but fall into the enclosure again ; and having once failed in their jump they never renew the effort."

\section{MYXINE.}

\section{(Gasteobranchus cacus.)}

Local names: Blind-fish, Borer, Glutinous Hog, Hog-fish, Poison Ramper, Ramper Eel. German: Schleimifsch, Blindfisch, Wurmfisch.

The Myxine, Glutinous Hog, or Borer, so much resembles a worm that it was placed by Linnæus in the class Vermes; and it was not till after examination by dissection and accurate descriptions, that it was recognised as related to the lampreys. 
The skeleton is rery imperfect, and in place of a series ci bones for the spinal column, there is simply a soft and pliant cartilaginous tube.

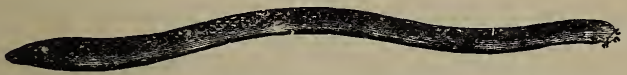

MYXINE (IIyxine glutinosa, Gastrobranchus cacus).

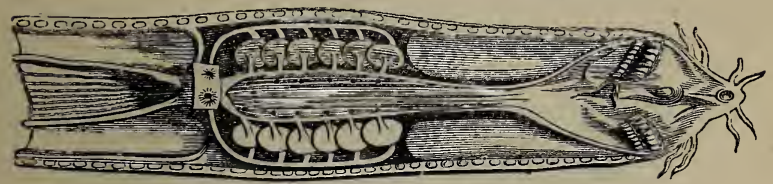

INTERNAL ORGANS OF THE MYXINE.

The eight barbules or cirri about the mouth are doubtless delicate organs of touch, which assist it in discerning the nature of the substances with which it comes in contact, and the single hooked tooth upon the palate enables it to retain its hold until its prey be brought within the reach of the double rows of teeth upon the tongue.

The Borers do much harm to the cod-line fishermen, they get into the cod when caught by the hook, and, almost eat him up. Mr. Baily, fisherman of Flamborough Head, tells me that the fishermen in that part of England call the myxine the "Devourer," and that very often the cod, coal-fish, ling, whiting, and haddock caught on the long lines are eaten away by the "devourer" until nothing but the skin and skeleton! is left.

Little or nothing is known as to the habits of this most remarkable fish, and I should be very glad if any of my readers would make it an object of study, and report the results. 
Acanthopteri.

\section{OPAH.}

(Zeus luna, Lampril guttatus, or Luna.)

Local names: King-fish, Sea-pert, Carf, Jerusalem Haddock.

THIs is one of the most brilliantly coloured of British fishes. I have never seen a fresh specimen, but from

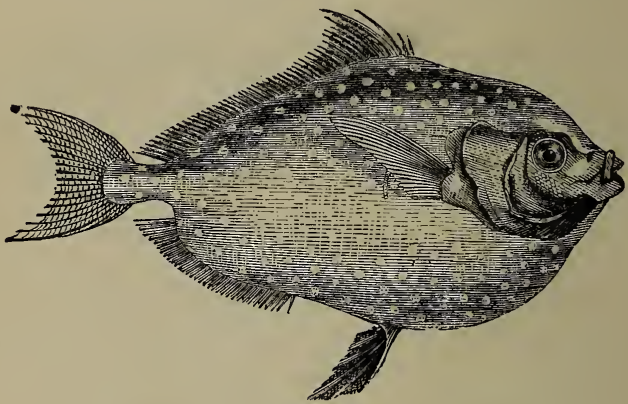

OPAH.

the figure in Couch it must be of perfect beauty. Its colourings, according to Couch, are as follow:-"The general colours are splendid red and green, with tints of purple and gold, dotted over with round silver-white spots; but in one instance, described by Nilsson, the spots of yellow and white were only below the lateral line. Iris of the eye scarlet, and fins a lively red."

His Grace the Duke of Argyll has a very fine model at Inverary Castle of an opah; it is made in paper, and beautifully coloured to life.

This fish is very rare in England. The Norwegians call it the Laxetoye, or the "large salmon." The Scandinavians call it the Glans-fisk. Zeus luna are two pretty names for it. It is rather an inhabitant of the northern than the southern seas, but it has occurred at 
Queensferry (Cornwall), near Conway (North Wales), and in Norfolk. I understand that specimens of opah have been obtained on the east coast, viz., Yarmouth, Hunstanton, and Eccles. It lives in very deep water, and is seldom seen. I am exceedingly anxious to get a specimen of this rare and beautiful fish for my museum.

Acanihopteri.

\section{THE PERCH.}

(Perca fuviatilis.)

Percida.

Local names: The Perch, Crutchet, Frasling, Hurling, Stitchling. German: Der Flussbarch, Frauling, Barsch. French : La Perche. Italian: Pesce persico.

Oun friend the Perch is one of the most beautiful fish which it has pleased Providence to place in our waters.

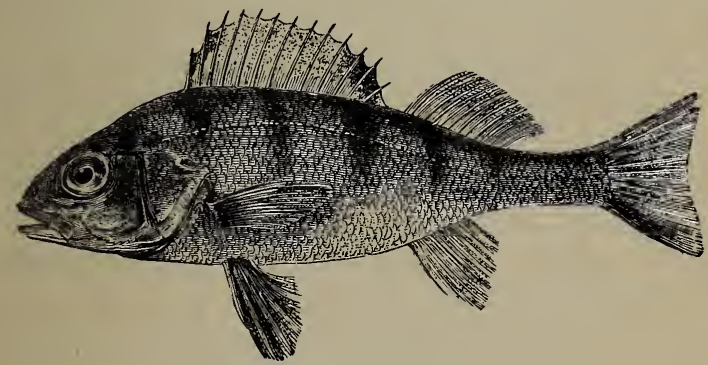

PERCH (Perca fluviatilis).

Not only does he afford to the angler excellent sport, but to the professed cook his arrival in time for the menu is most welcome, as witness "water souche," as served at Ministerial dinners, City banquets, or private parties at Richmond, Greenwich, \&c.

No lady's dress was ever made so beautiful as that of the perch's when he is in full season. His cuirass of scales is formed of a lovely bronze, with transverse bars 
of dark green brouze, while the whole is shaded with a lovely peacock iridescence. His fins are coloured with a lovely tinge of red, such as we may sometimes see in the glass of very old church windows, or occasionally in Salviati's beautiful glass. Artists would do well to study the colouring of the perch. They will not find such brilliancy of colour or such a combination of tints in any flower.

Whoever has studied Bell's "Anatomy of Expression" cannot fail to have observed the various emotions of animals as represented by their physiognomy. Witness the difference between the hair of the fox terrier when sniffing at a fox's earth, and when sitting up on his hind legs begging a bit at his master's dinner-table. Witness also the expression of the fox as he meditates an attack on the coiled-up hedgehog so beautifully described by the author of "Comment l'Esprit vient aux Bêtes" as follows: "Une sorte de rictus relève sa lévre, un sourire mephistophélique illumine la face d'Escobar, et lui donne une vague ressemblance avec ces satyres si fort en vogue chez les enlumineurs du moyen âge." As his tail is to be the index of the dog's mind, so the armament of spines on the back of the perch may be said to be the index of the perch's mind. When quiet and enjoying himself, the perch sheathes, as it. were, his back fin-a case of "slope swords ;" when, on the contrary, he rushes forth from his concealment, lis bristles are all erect, as though he had heard the quick, rattling word of command, "Carry swords!" These perch spines are very sharp pointed, so sharp that, as the French author has smartly put it, "Il fait. penser au chat."

He is a carnivorous gentleman is the perch; his bon 
bouche is a lively worm. In the matter of worms, however, he has a choice; he likes a middle-size worm, the tail of which, by his movements, attracts his quick eye. The worm when on the hook should be moved gently up and down in the water, and it is generally on the ascent of the worm that the perch takes it. He is also aspecially fond of a small frog, of which specimens may be here and there found along the banks by the fishermen. Perca fluviatilis is particularly fond of minnows, and where minnows abound perch are always in fine condition. Those, therefore, who have perch in their ponds or lakes would increase the quality of their perch very much for the table by breeding or catching minnows for them. The fry of roach or dace would also be acceptable.

The young roach and dace that may be observed on hot days sunning themselves after their recent escape from the egg form a favourite food for the perch. I have heard of a plan of placing several minnows in a common fish globe, with muslin tied over the top, so that the minnows shall not escape. The captive minnows form, when sunk in the water, a very attractive lure for the perch. Perch, if you may judge from their biting, are very sensitive to electric changes in the atmosphere. During the hot days of summer, when the south wind blows, the perch is on the feed the whole day. During other days he feeds much in the morning, little in the evening, not at all in the day. Perch differ very much in quality in respect to the soil. They do not like water which is too swift. Their conformation and mode of catching food leads them to delight in eddies under the piles of bridges, back streams of rivers, and in quiet water at the sides below weirs. They are very common in ornamental waters in private 
parks; and, under such circumstances, if not properly netted, perch are very apt to degenerate and become very small. The reason of this is that they are over-stocked; and, whereas they breed very fast, they starve one s.nother. The remedy is, of course, to shift to anotherplace or destroy at least one-third of these young perch, and to feed the remainder regularly.

The gardener and the gardener's boys, therefore, should have orders to collect all the worms they possibly can, and during the summer a tub half filled with bran should be instituted wherein to breed gentles in the same manner as is done by the gamekeeper for young pheasants. The percli should always be fed at or near the same place in the pond; and I know no better amusement for a country house than an afternoon's perch-fishing.

When out on fishing expeditions nothing adds so much to the enjoyment of the day as to cook for luncheon the fish which have been caught by the party. I therefore beg to quote the following excellent receipt, which is given by a writer who signs himself Caerdyaa. Quære -what language is this? Is it Welsh? The gentleman with the funny name writes as follows: "Fish may be most perfectly cooked by the river side. Take the fish as caught, not drawn or otherwise cleaned, procure some stiff clay, and with it give the fish a thin coating about the sixteenth of an inch thick; failing the clay, lightly envelope it in several coatings of paper-newspaper will answer admirably; thoroughly saturate the paper by holding it in the water, having previously lighted a fire of wood or sticks so as to produce a quantity of hot fire-holding embers. Give the fish in the case of clay twenty minutes therein; if the fish is in newspaper give them twenty minutes longer; time must. 
be allowed according to size. Fish done in this way are perfection."

If the angler goes out frequently fishing, he should get a charcoal store, which has a grating on top like a gridiron; this can be kept in the punt, and the fish can be easily cooked on the bars of this portable stove.

Perch, I think, have more intelligence than most other fish. The best way to test a fish's intelligence, like that of other animals, is by appealing to their appetite. At the aquarium at the Zoological Gardens, Tennant, the keeper, was accustomed to frequently feed the perch with live minnows. After a while the perch ascertained by a process very like reasoning that the minnows were kept in another portion of the fish-house. Whenever . they saw Tennant go near the place where the minnous were leept, they began to rush about as if in anticipation of the welcome feed which, somehow or other, they had ascertained was forthcoming for their benefit.

I now give the list of the largest perch that have come under my notice during the last few years.

Dr. Norman sent me two fine perch in April, 1868, caught in the Norfolk Broad; they weighed respectively 3lbs. 2oz., and 2lbs. 11oz. Wishing to know the number of eggs they contained, they were counted by myself and secretary. We found that they amounted in the larger one to 155,620 , in the smaller, 127,240.

Dr. Norman also informed me that a fine perch, weighing $4 \frac{1}{2} l b s$., was taken on a trinner in the Wroxham Broad, Norfolk; and that another was taken in the Bure in March, 1868, which weighed also $4 \frac{1}{2} \mathrm{lbs}$. 


\section{SEA PERCH, OR BASS.}

(Perca labrax.)

THE Bass, or Sea Perch, is a handsome, well-shaped fish, though it is destitute of the strongly contrasted colouring and zebra-like bars of the fresh-water perch, from which it is also distinguished by an abundance of small teeth upon the tongue. It is common in many parts of England, and is of migratory habits, generally coming in towards shore at its proper time. The upper parts are grey, with bluish reflections, which gradually shade into a silvery-white on the lower parts; the fins are grey, the pectoral ones slightly tinged with red. At some periods they appear to be marked with spots or clouds; when young they are as bright as a new shilling, and very beautiful. In Kent they are called the White Salmon, or Salmon Dace. These fish arrive from the deep sea in the month of June and remain till October. When they are on the feed, a basket of $15 \mathrm{lbs}$. or $16 \mathrm{lbs}$. is not uncommon : they are caught by the rod to the weight of $91 \mathrm{bs}$. , but one has been taken 22lbs., close to the pier at Herne Bay, with a net. The mode of fishing is with an ordinary trolling rod, and tho bait used is the sand-eel. An excellent artificial bait of india-rubber for bass is made by Mr. Hearder, fishingtackle maker, of Plymouth.

Casts of bass can be seen at my museum, the largest being $15 \frac{3}{4} \mathrm{lbs}$. This fine fish was caught at Poole, Dorset, and presented to me by Mr. Penry of that place. When taking a bass off a hook mind his back fin. 


\section{3}

Abdominales Malacopterygii.

\section{PIKE.}

(Esox lucius.)

Local names: Jack Luce, Gedd, Pickeral, Haked, Lul, Pod. Welsh: Penhwyad. French: Le Brochet. German: Der Hecht, Hak, Schnock, Wasserwolf. Dutch: Greepvisch, Snoek. Norwegian: Gedde. Italian: Luzzio, Lucio, and Brochette. Danish : Gjedde. Swedish: Gadda, Gadda Snipa.

The best name of all the above applied to the Pike is the Waterwolf.

From the days of Gesner downwards, more lies-to put it in very plain language-have been told about the pike than any other fish in the world; and the greater the improbability of the story, the more particularly is it sure to be quoted. Among these stories there can be no greater fabrication than that of the pile that is recorded to have lived two hundred and sixty odd years. An account of this precious fish can be found in almost every

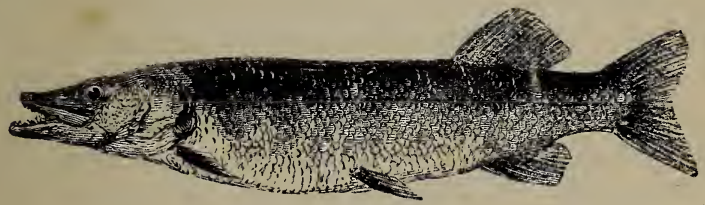

IIKE.

angling book published. We are now in 1880, and supposing the fish to have been caught in this year, it follows he must have been put into the lake in 1630 , the sixth year of the reign of Charles $I$. This story might have done very well years ago, but will not do now.

I now proceed to put on record the largest pike that has come under my own personal knowledge. 
In Oct., 1874, His Royal Highness Prince Christian was kind enough to send up Keene, the head fisherman of Windsor Park, with the most splendid pike I ever beheld. Having understood that Rapley Lake near Bagshot Park, which belongs to the Royal domain, had not been dragged for upwards of fifty years, Mr. Keene put in the nets in order to report to the Prince what stock of fish he had there. The net brought out a number of carp, tench, \&c. Keene thought from the jump of something in the net that he had caught an unusually large fish. When the net shoaled, he was delighted to find a monster pike in it; the fish ran between his legs, and nearly upset him. He took his prize at once to Cumberland Lodge to the Prince, who was good enough to send it on to me immediately. This magnificent fish weighed no less than thirty-five pounds ; length $3 \mathrm{ft} .10 \frac{1}{2} \mathrm{in}$., girth $2 \mathrm{ft}$. I never saw a fish in such perfect condition before. The eye was exceedingly beautiful, the head shone like smoked mother-o'-pearl, every scale was perfect, and fins as red as a perch; four black bars extended from some distance from the tail upwards, giving the fish a zebra-like appearance. Mr. Keene asked me what I thought the age of the fish. I guessed offhand from twelve to fifteen years; and it really appears I was not far wrong, for about twelve years before, Sir James Clark's butler put six or eight jack weighing about a pound a half each into Rapley Lake.

This fish was a female, and contained ovcr forty-three thousand eggs.

I regretted much that this freshwater shark was not kept alive, and sent either to Westminster or Brighton Aquarium.

I made a cast of this fish, which was afterwards 
painted by Mr. Searle, and exhibited at the Berlin Fishery Exhibition of 1880.

In February, 1879, I was favoured by receiving from Col. W. G. Colville, Clarence House, St. James's, a magnificent pike which H.R.H. the Duke of Edinburgh had himself caught at Eastwell, his country seat, near Ashford. This pike was a very handsome female; she weighed twenty-four pounds, and measured more than 3ft. Mr. Searle and myself cast the fish, and Mr. Searle afterwards painted it. I had the honour of presenting it to the Duke, and it is now fixed in a prominent position in the entrance hall of Clarence House. This pike, I found, contained a great many eggs; these were in two lobes side by side like the hard row of the herring. The eggs were the size of turnip seed; they weighed altogether 2lbs. $4 \mathrm{oz}$.

Mr. Searle, my secretary, weighed several grains, counted them, and averaged them, and thus got at the contents of the whole mass, which numbered no less than 224,640 eggs.

When we consider this enormous number of eggs in one fish, it seems wonderful to imagine what becomes of them all. The number of eggs in this one fish was equal nearly three times the population of Brighton; nine times the population of Windsor; or nearly half the population of Liverpool. Jacks' eggs no doubt afford food for numerous water insects, as well as to roach and fishes of the carp tribe, which, I know from experience, are great eaters of eggs. It is quite as well for the economy of the fish world in the Duke's lake that this large pike should be destroyed, as without doubt this monster kept all the fish in the pond in a state of terror.

The most successful angler for pike in modern times is Mr. A. Jardine. In November, 1879, Mr. Jardine 
caught in fair angling, by means of a dace, snap-tackle, and a cane rod, a grand pike, which, after having been out of the water twelve hours, scaled $34 \frac{3}{4} 1 \mathrm{lbs}$., so that it was a good $35 \mathrm{lbs}$. fish. It measured $46 \frac{1}{2} \mathrm{in}$. in length. This fish was taken to $\mathrm{Mr}$. Rolfe, and its portrait was put on canvas to form the centrepiece of the picture which was presented to the Right Hon. Anthony Mundella, M.P., in 1880, in acknowledgment of his great public service in getting the Freshwater Fisheries Act through Parliament.

In February, 1877, Mr. Jardine was fortunate enough to take with rod and line another pike weighing thirtysix pounds, measuring 46in. in length, and 25in. in girth. Immediately the fish was captured Mr. Jardine brought her up on the top of a four-wheel cab, and while $\mathrm{Mr}$. Searle and I were casting the fish Mr. Jardine gave us the following most interesting account of its capture, which I took down at the time:

For some days previously to Mr. Jardine's arrival the water where the pike lived had been very thick and muddy; in fact, like pea-soup. During this state of things the pike had been short of food. With the clean water arrived Mr. Jardine, who happened to find my lady in the middle of her dinner. Previously to taking Mr. Jardine's baits she had swallowed no less than fourteen roach and one perch, which were all more or less in a state of semi-digestion. When Mr. Jardine first felt the tug upon his line, he fancied that he had hooked only a small fish, as the fish came along towards him without much pulling. When, however, the fish was struck smartly, she began to show fight-first of all tried to make a bolt of it, and then rushed violently through the water, with open mouth, towards Jardine, the tightened line still in her jaws. 
Coming along the side of the boat, she "grinned a ghastly grin," and two pairs of eyes met-the man's and the fish's-with dire defiance of each other. The pike then shook her head severely, after the manner of a dog worrying a rat; all in vain, the hooks were too firmly fastened into her tongue, and they could not be shaken out. Off went the pike again for another waltz round the pool, and then came a deal of manœurring on the part of the fisherman. The skiff-not a flatbottomed boat-was anchored in deep water by a rope and chain, and Jardine's fear was that the fish would manage to twist the line round the rope, in which case the line would in all probability give way. He therefore tried all he could to get up the anchor. Kneeling on one knee, he pulled hard at the anchor-rope, while he played the pike with the other hand; but no, the anchor would not come up, so he devoted his entire attention to the fish. After dancing a pas de deux with his partner for a long time, the fish began to give way, and to roll herself languidly about several times. Jardine brought her near the side of the boat, and several times did she again plunge into the depths below, making great swirls with her tail.

"Illam ter fluctus ibidem

Torquet agens circum, et rapido vorat œquore vortex."

Still, the difficulty remained how to get the fish into the boat. Piscator, however, was ready for any emergency-when is he not? Slipping the gaff, without the fish seeing it, gently into the water, with a swift jerk he chucked her under the chin. Having felt the hold was firm, he dropped his rod, and put the finger of his other hand into the pike's eyes. Another moment, and the pike was in the skiff. Then came the tug of 
war between man and fish. The pike, feeling for the first time herself out of water, began to lash about most furiously. Jardine stopped this little game with a slight blow on the head, which had only a slight effect in felling the fish.

The fish, however, was determined to do as much mischief as she could. Lashing her tail about like a crocodile, she first upset the large bait-can, which contained the live baits, so that there was a merry morris dance in the boat, the big fish surrounded by the little ones. She then made a charge upon Jardine's commissariat. Smash went the bottle of sherry, then a tumbler, then the sandwiches and a tobacco-box.

Affairs were becoming very serious, for the pike had rolled up all the loose lines; Jardine then tried to get her head into a sack. No sooner was her head into the sack than it popped out again, the fish seeming to be aware that if Mr. Jardine "gave her the sack" it was all up with her, as is the case with the Sultan's wives, who, when disobedient, are put in a sack and tumbled into the sea. This, I believe, is the origin of the term, " giving the sack."

At last Jardine managed to get towards shore, when the keeper at last-gone to his dinner, of course-came to his assistance. The two of them contrived to bag the pike effectually, and they carried her a long way inshore before they gave her the final coup-de-grace.

The Avon, Christchurch, Hampshire, is not only celebrated for large salmon, but also for large pike. My friend Mr. Payne, of Avon Tyrrell, Hants, tells me that he formerly possessed outlines of a pike cut out in wood which weighed $37 \frac{1}{2} \mathrm{lbs}$. He has also a peculiarly short pike caught by himself, which weighed 32lbs.

Lord Normington, who lives on the banks of this river, 
was kind enough to show me a cast of a pike which had attempted to swallow a salmon. In May, 1880, I received a call duck from Lord Nelson, of Trafalgar House, Downton, which had been attacked by a pike and was so much lacerated that it died of its wounds. This must have been a very big pike. He is not caught yet. Pike will also eat young ducks, and I understand that in the Stour, which joins the Avon at Christchurch, the pike make considerable inroads into Lord Normington's young wild ducks. They will also take water rats.

In October, 1869, my friend Mr. George Rooper sent me a very fine pike, which he caught when spinning in a gale of wind (best time for pike-fishing) in Loch Awe. This grand game fish gave splendid sport. When she arrived at Albany Street purposely to have her likeness taken in plaster, we found that she weighed $28 \mathrm{lbs}$., and measured 3 feet 7 inches in length. She contained $21 \mathrm{oz}$. of roe, the number of eggs being 292,320.

On April 2, 1870, I received a pilie which weighed 32lbs., and measured 3 feet 8 inches; it was caught with rod and line in the Broads of Norfolk. Upon opening the abdomen, the roe was seen almost filling the whole of the cavity; it weighed 5lbs., and contained no less than 595,200 eggs. This fish I cast, and afterwards presented it to the Royal College of Surgeons, where the skeleton is now placed in the museum.

The lake at Blenheim Park was made in Queen Anne's time, when the palace was built by Bamburgh. This architect, or his landscape gardener, blocked up a stream and made a splendid lake; but although this lake was left for many years without being touched, yet when it was properly netted for the Duke of Marlborough by a professional fisherman from Oxford, no very large pike were found in it. The Duke kindly sent me on 
the 12th May, 1872, a pike weighing $24 \frac{1}{2} \mathrm{lbs}$. This fish did not give one the idea of being of great antiquity; in fact, he could not have been very old.

Two cases of a curious accident to pike have occurred of late years. In April, 1870, Mr. Cramp sent me from Killin, a well known salmon rod-fishing station at the head of Loch Tay, two pike fastened firmly together by the impaction of the head of one within the mouth and jaws of the other. Mr. Cramp writes: "These two pike, which weighed $191 \mathrm{lbs}$. the two, are exactly in the same position as when gaffed by my boatman on Loch Tay. We saw a considerable movement on the surface of the water, and upon our approaching to discover the cause, the fish appeared to be fighting, and merely sank a short distance below the surface. The gaff penetrated both their heads. You will observe that the head of the one fish (weighing, perhaps, 9lb.) is tightly inserted up to the termination of its gill, and part of the first lower fin in the mouth and throat of the larger one."

A cast of this curious case of Pike $v$. Pike is now in my Fish Museum.

A second case of pike swallowing a pike occurred in April, 1880, when Dr. Burton, of Kelso, sent me a drawing with the following account:

"Two pike, the larger $3 \frac{1}{4} l b s$., the lesser $2 \frac{1}{4} l b s .$, were this day taken by the hand by a lad out of the Tweed at Kelso, the one nearly half swallowed by the other. They were both alive, and when with difficulty separated and put into a water-tub, the larger made two attempts again to gorge his neighbour. The lad who took 'em wondered to see ' a muckle fish wi' twa tails." "

The cause of this curious accident in both cases was probably that both fish charged simultaneously st a roach or other small bait. The roach slipped out 
of the way, and the pike having got up stream, had too much way on them to avoid a collision; the head of the smallest becoming thus impacted in the open mouth of the larger one.

I strongly advise my readers to make a preparation of a pike's head. This is very easily done by cutting it off, steeping it in spirits of wine or diluted carbolic acid, then hanging it up to dry, the mouth being blocked open with a stick. It will then be seen that there are three plates of teeth in the back of the upper jaw, all of which are as sharp-pointed as needles, and are set directly backwards. The lower jaw is also armed with a formidable set of lancet-pointed teeth, so that it is almost impossible for any object once impacted in a pike's mouth ever to get back again.

When in the 2nd Life Guards, my much-lamented friend, the late Colonel Martyn, took the lease of Ruislip Reservoir, near Uxbridge; many happy days have I spent there fishing for pike from a punt. Colonel Martyn was particularly fond of what he called the "calves'-tail" bait for pike, a description of which I have never before published.

Procure the tip of the tail of a brown calf; remove the bone and substitute a slip of cork; make a head with a champagne cork; put into it boot buttons for eyes; attach a piece of leather boot-lace for a tail, and dress with ordinary hooks. These big lake pike, who are very artful fellows, will not be up to this calves'-tail bait-they will take it for a swimming water-rat, and the chances are that they will snap at it, especially on a windy day. 


\section{THE PILCHARD.}

Abdominales Malacopterygii.

Clupeida.

(Clupea pilchardus.)

The Pilchard is easily distinguished from the herring by its dorsal fin being placed at the centre of gravity, i.e., when you hold the pilchard up by the back fin, the fish will be horizontal; whereas the herring will dip downwards his head or tail. The average length of a pilchard is nine and a half inches; depth one and three-quarters to two inches; the maximum length ever known being fourteen inches.

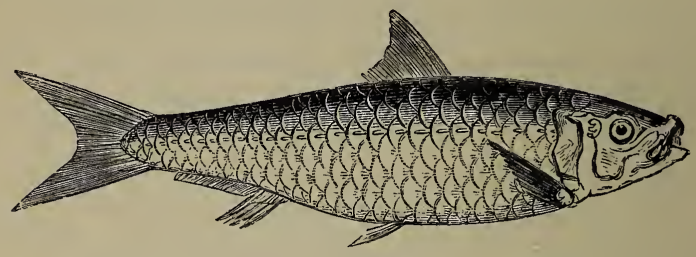

PILCHARD.

The chief pilchard fisheries are in Cornwall. There are three districts from which pilchards are caught-the north coast from Hartland Point to the Land's End, in the centre of which is St. Ives; the Mount's Bay district, from the Land's End to the Lizard; the East Lizard, extending to the Start. The fishery is very uncertain. In fine weather the rate of the swim of a shoal of pilchards is from one to two miles an hour, in stormy weather from five to seven miles an hour.

My friend, Mr. Howard Fox, of Falmouth, who is very much interested in the pilchard fishery, has kindly published at my request three articles in the columns of Land and Water, and I have no hesitation in 
reproducing, in the form of an abstract, his valuable information.

He thus writes:-

" One drawback to the complete success of the pilchard fishery is the absence of any market for the cured fish other than the Italian, in which there is a great demand both before and during Lent. An experiment was once made to smoke them in the same manner as herrings. It was found that the weight of the body broke the neck, and the fish fell into the fires.

"The approved method of cooking them is to split and pepper, place one fish flat on another, backs outside, and roast on a gridiron. This is the process provincially termed ' scrowling.' An admirable way of curing them is that of ' marinating.'

"The mode of curing pilchards into 'fumados,' or 'fermade,' is as follows: Women arrange them; first putting a layer of salt, then a layer of pilchards, and so on till the 'bulk' is from three to five feet high; the outside row of fish are laid with their heads out and slightly turned up, and the inner rows at right angles to them. French and Spanish salt, being a larger grain, is much preferred to English for this purpose. The fish remain in the bulk thirty days, during which time brine and oil drain from them into pits specially arranged for the purpose. They are then taken out, sifted free from the dry salt, washed in another sieve, and placed in ragular order in casks of fifty gallons, called hogsheads ; the tails of the fish pointing to the centre and heads out. Pressure is next applied by means of levers, to which weights are hung, and the casks are refilled and pressed three times during the space of nine days; when the weight of the hogshead should be $476 \mathrm{lbs}$, and the fish in each cask will vary from 2,500 to 3,000 , accord- 
ing to size; all under eight inches in length being usually excluded and packed separately in other casks to be sold as small fish, chiefly for home consumption. The oil expressed from the pilchards is used for making paints."

Pilchards are caught by driving-nets and seines.

Boats, with nets complete, cost a considerable amount. They are manned by from three to eight men. Each boat has from fifteen to thirty nets.

As pilchards only enter the nets during twilight, unless they are passing in large "schools," when they often carry the nets away bodily, the general custom is for the boats to start from home in time to reach their fishingground about sunset, when they set their nets, and haul them in in about two hours, and, unless they are full of fish, do not set them again till dawn. In the interval they sail about to discover the whereabouts of "fish," which they do by knocking the bottom of the boat with a hammer, or stamping on it, the concussion arising therefrom causing any pilchards in the neighbourhood to jump and discover themselves by " briming," that is to say, causing a brilliant phosphorescent appearance in the water, when the nets will again be cast overboard. As many as 80,000 pilchards have been captured by a single boat in one night, and 40,000 , though a very good, is not an uncommon catch at certain seasons. The fish when landed are sold fresh, at prices ranging from $1 \mathrm{~s} .3 \mathrm{~d}$. to 2 s. 3 d. per 126.

The seine fishery commences about the end of July. The more general and successful method of enclosing fish is for the seine boats to receive their signals from a man called a "huer," stationed on the top of the nearest cliff, who, from this vantage ground, can have a much clearer sight of the fish. The huer has a furze bush or 
other signal in each hand, and by preconcerted movements can accurately guide the boats below. When "fish" are passing, the inhabitants rush about shouting, "Hev'ah, hev'ah, hev'ah!"

The seiners have various difficulties to encounter when trying to enclose a shoal of pilchards, and it is more common to miss than to have a successful "shoot." The tide has to be carefully considered, for it runs with great force off all the headlands, and often carries a seine on to a rock and splits it. After a shoal is fairly enclosed and the seine moored, there are still many dangers and perils; for instance, the Rashleigh seine at Port Gavern, near Tintagel, enclosed a fine shoal, but next day a ground sea came on which lifted the foot-ropes, and enabled the fish to escape.

The fish being duly secured, the next thing is to take them ashore. This is accomplished by means of the " tuck net," which is passed inside the main seine. The ends of the tuck net are then drawn together, and the fish are lifted in the bunt from the bottom.

The following is the correct mode of measuring pilchards:-A hogshead is 376lbs. gross, and about $340 \mathrm{lbs}$. nett. Summer fish run 3,000 to 3,600 per hogshead ; winter fish, 2,400 to 2,800 per hogshead.

Through the kindness of Mr. Howard Fox, of Falmouth, I have received the following returns, giving the shipments from Penzance and Falmouth of pil-

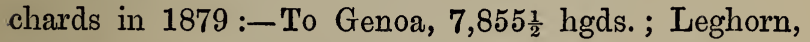

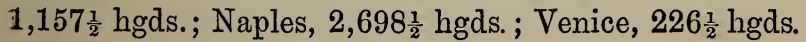
As nearly all the Cornish pilchards go to Roman Catholic countries the fishermen have a favourite toast, "The Pope and Pilchards." 


\section{PILOT FISH.}

Acanthopteri.

(Naucrates ductor.)

Scombrida

French : Pilote.

Mr. LEDGER, of Folkestone, in October, 1868, kindly sent me a pilot fish, which had been taken off Folkestone in the mackerel nets. It was about the size and shape of a small mackerel; its lines are evidently made for going at great speed through the water; it was 9 in. in length, and weighed $8 \mathrm{oz}$. Its colours when first received were very beautiful-an emerald green, showing different shades, like a lady's shot-silk dress, the sides being striped with broad bands of ultramarine colour. I made out three distinct "par marks" on the body; the head and the caudal portion of the same colour as the bands. Upon the tail there was also an indication of the same blue colour; the tail much bifurcated, and each point tipped with a snow-white cap. The tongue is peculiar from having round its external margin a white leather-like fringe loosely attached. One might almost conceive that this was as a fringe of "tasting " tongue fastened on the edge of the "prehensile" tongue; doubtless it is of great use to the fish in his economy. The mystache is small, graceful, salmonoid in appearance.

Everybody knows the story of the pilot fish acting as "guide, philosopher, and friend" to the shark. My own faith, however, is that pilot fish follows the shark to eat the parasitic insects off his body.

In Land and Water, December 18th, Mr. H. Lee writes :-

"I received, in the third week of September, from Messrs. Mussared and Doughty, fishmongers, Margate, 
a fine specimen of the pilot fish (Naucrates ductor), then just captured in Ramsgate harbour. A fisherman saw it basking on the surface of the water, struck it with one of his boat's stretchers, and brought it ashore. Mr. Mussared fortunately saw it exhibited as a curiosity and purchased it on my account, for a rather 'considerable consideration.' I need hardly say that very soon after its arrival it was on its way to Mr. Buckland, for immortalisation in plaster effigy. It is now in the Fish Museum."

Many well-authenticated instances have been published of the pilot fish following ships for long distances. This specimen had probably followed some "over the sea" inward-bound ship, and had lost her when she took a steam-tug at Ramsgate.

\section{Lophobranchii.}

\section{THE PIPE-FISHES.}

THESE fish have a remarkable appearance: the body being long and slender, and the jaws united, and forming a cylindrical tube, the whole covered with bony plates, like a coat of mail. The arrangement of these plates is such as to render the body angular, but they do not interfere with its flexibility. The reader should boil one of these fish till it falls to pieces, the peculiar pattern of the armour scales can be then well observed. The most remarkable peculiarity is the existence, in one genus, of a marsupial pouch, in which the young are contained. This receptacle is found only in the male pipe-fish, which is furnished with two soft flaps, that fold together and form a bag or apron, in which the eggs are placed and matured, and the young hatched. 
The Great Pipe-fish, or Needle-fish (Syngnathus acus ; German : Grosse Meernadel; French : L'Aiguille de Mer), is found at low water, among sea-weeds, and at other times in deep water. It attains a length of between 12in. and 16in. in this country. It swims about slowly, in a singular manner, horizontally or perpendicularly, with the head downwards or upwards, and in every attitude of contortion, in search of its food, which seems to consist chiefly of marine insects.

It is believed these fish are able, by dilating their throats at pleasure, to draw their food up their long, cylindrical, beak-like mouths, as water is drawn up the pipe of a syringe. In common with all the others belonging to this family, this fish is of no use either as food or bait, its dry rigid body being much like a piece of wood.

The Deep-nosed, or Lesser Pipe-fish (Syngnathus typhle; German: Kleine Meernadel; French : Le Typhle), is almost as abundant as the preceding species.

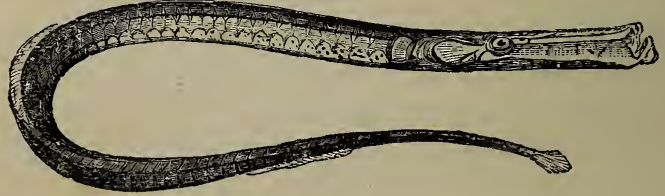

DEEP-NOSED PIPE-FISH (Syngnathus typhle).

The species next to be noticed belong to a different group in the same family, and differ from the former in having a dorsal fin only-no pectoral, ventral, or anal fin, and no abdominal pouch in either sex. They are much more slender and worm-like in shape. There is a great difference in the motions and changes of position observable in this genus. The marsupials, which (as we have seen) possess a stiff, short tail, provided 
with a fin, swim like other fish, chiefly by the help of strokes of the tail; while the ophidial pipe-fish, as they are called, have a long, roundish, tapering, and very flexible tail, which is generally kept still when swimming, and may be regarded as a helm rather than an oar. The creature entwines this supple tail with great dexterity around any object that may be at hand, and may be seen holding fast in this manner whenever any convenient thing presents itself; but when no such support is near to serve the purpose, several individuals placed in the same vessel will entwine their tails together, and thus form concatenated groups. The grasp of this fish's tail reminds one somewhat of the spider-monkey.

The Equoreal Pipe-fish (Syngnathus aquoreus) appears to be very rare. The Cornish fishermen report that they have seen it far out at sea, swimming at the surface, over a great depth.

The Snake Pipe-fish (Syngnathus ophidian; German: Meerschlange) is much rounder and more slender than the former; its body scarcely exceeding the thickness of a goose-quill, and it has a remarkably long, narrow tail.

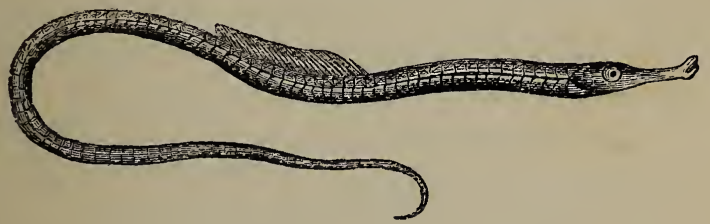

SNAKE PIPE-FISH (Syngnathus ophidian).

Although destitute of the abdominal pouch, there is provision made in this genus for the performance of a function similar to that which is executed by the marsupial fishes. It appears that the eggs are carried, for a time, by the male parent fish, in small cells or 
depressions which exist on the surface of the abdomen. Mr. Yarrell says that he found specimens, taken in August, which contained one egg, of the size and colour of a mustard-seed, lodged in each cup-like cell. The females were not provided with these receptacles.

The snake pipe-fish is often taken in the whitebait nets in the Thames, and is also found in the Severn, as far as Newnham. The young of this fish is often eaten among ordinary whitebait. I have often found them in my plate at dinner-parties and at clubs. They are very good eating. A plate of whitebait often forms an ichthyological study.

The Worm Pipe-fish (Syngnathus lumbriciformis) is the smallest of the British species, and is taken on various parts of the coast. It does not exceed five or five and a half inches in length. It has no fin, except a small one on the back. The nose is very short, and turned upwards. The colour of the body, like that of the preceding species, is olive-green. "It seems to pass through a kind of metamorphosis when young; the whole of the tail, when it escapes from the egg, being enveloped in a thin membrane, and small pectoral fins are visible; both of which, after a time, disappear." Hence it would seem that these fish undergo something of the same process as tadpoles.

In his "Dictionnaire des Pêches," M. De la Blanchère remarks that "it is probable that these fish possess a peculiar smell or taste inappreciable to our senses, but discovered immediately by fishes. When chopped up with other fishes, and given as food to aquarium fishes, such as turbots, gurnards, \&c., if by chance the bits are swallowed, they are immediately rejected with apparent disgust." 
Lophobranchii.

\section{HIPPOCAMPUS.}

There is only one British species, the Short-nosed Hippocampus (Sea-horse, or Hippocampus brevirostris; German: Seepferdchen; French: Hippocampe). Specimens have been found chiefly in the south of England; at Guernsey, and the other Channel Islands.

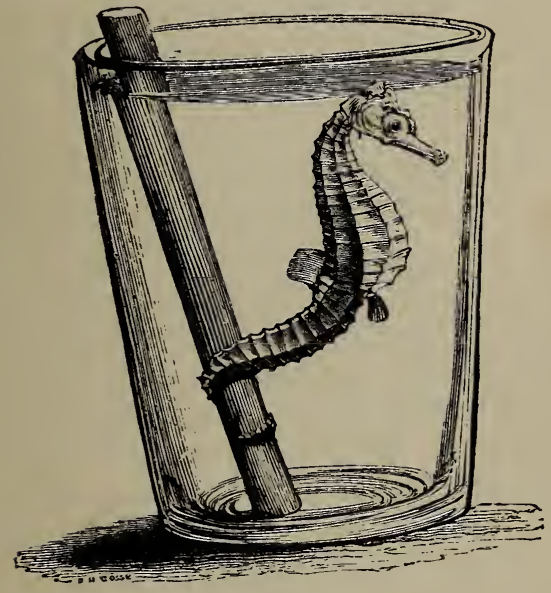

HIPPOCAMPUS.

Mr. John Keast Lord, when reporting on two specimens of hippocampus sent to the office, thus writes in Land and Water :-

"Only one species of hippocampus ( $H$. brevirostris) has been taken on our British coasts. The hippocampus is best known in its dried condition, exhibited in cabinets, as a 'wonderful sea-horse,' the head bearing some fanciful resemblance to that of a horse, and the tail to that of the fabled dragon. Seen in its native element, however, this horse-like appearance vanishes, and the dragon-like tail is found to be an admirable 
contrivance, with which the hippocampus moors itself to any floating object.

"Whilst swimming, the body is maintained in a vertical position, and the grotesque-looking creatures seem to be walking upon their tails rather than rowing themselves through the water. The prehensile tail twists and turns about, ready at the shortest notice to coil round the drifting sea plants or a piece of floating wood; and thus, as it were, lashing itself to a spar, the sea-horse floats idly along as the breeze or the current directs its course.

"The hippocampus possesses the power of moving either of its yellow-coloured eyes independently of the other. When watching their comic faces as they drift about, one can hardly help thinking that they are 'making eyes' at you, so strangely do they roll and twist them about in opposite directions. The male, as in all the marsupial pipe-fishes, is provided with an egg pouch, which is situated underneath the tail, and formed by a doubling in of the thick skin."

\section{PLEURONECTIDA.}

Pleuronectide, of course, signifies side swimmers; in common parlance, Flat-fish ; in my language, as Inspector of Fisheries, Trawl-fish. There are so many of these fishes that I can only mention some of them.

The following is the catalogue of the Flat-fishes found along the British coasts.

Brill (Pleuronectes rhombus).

Dab, common (Pleuronectes limanda, Platessa limanda).

Dab, long rough (Platessa limandoides).

Dab, smooth (Platessa microcephalus).

Flounder, common (Platessa flesus). 
Flounder, long (Platessa elongata).

Fluke, sail (Zcugopterus velivolans).

Fluke, pole or craig (Platessa cynoglossus).

Halibut (Hippoglossus vulgaris).

Plaice (Platessa vulgaris).

Sole, common (Solea vulgaris).

Sole, earter, lantern, or whiff (Zengopterus megastomus).

Sole, lemon (Solea pegusa).

Sole, variegated (Solea variegata).

Solenette (Solea lingula).

Sole, smooth or megrim (Amoglossus lavis).

Turbot (Rhombus maximus).

Topknot, Muller's (Pleuronectes punctatus).

Topknot, Bloch's (Zeugopterus punctatus).

Topknot, Ekstroms (Rhombus Norvegicus).

The Lemon, or French Sole (Solea pegusa, aurantiaca), is a pretty fish, with colours of orange and light brown, and freckled over with numerous small round brown spots; on the under side of the head some very pretty blue spots appear. The pectoral fin presents somewhat a remarkable appearance, for on being spread out a black patch appears, looking very like the wing of a butterfly. It is wider in proportion than the common sole, but is much smaller, its length not exceeding ten or twelve inches. The under surface white, and the head without the papillæ. It is said to be occasionally taken at Brighton with the common sole, when trawling over a clear bottom of soft sand; and as this happens most frequently in the direction of the French coast, the fishermen sometimes call it the French sole ; others call it the lemon sole, in reference to its yellow colour. 
I received a pair of these soles in February, 1867, measuring respectively thirteen and fourteen inches. Mr. Thomas tells me that the skipper of his trawler, the Hurricane, often catches them in the North Sea, but they are not often sent to market.

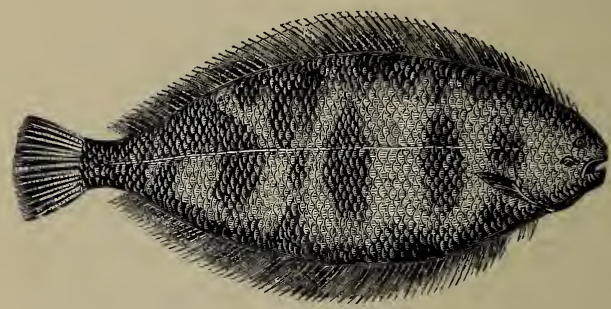

VARIEGated SOLE (Pleuronectes variegatus).

This variety very much resembles the common sole, but is distinguished by the small size of the pectoral fins. It is a small fish, scarcely attaining half a foot in length; one bought in Plymouth market measured 9in. in length. But little is known of the habits of this species; it appears about Plymouth in the spring. The colour of the surface is a very light brown, tinged with red, clouded with darker shades; the scales large and rough to the touch. It is a rare species, but I have a specimen.

The Solenette, or Little Sole (Socea parva, Solea lingula), seldom exceeds the length of $5 \mathrm{in}$. It is taken in the trawl nets on the Devonshire coast, where it is called the red sole; but on account of its diminutive size is seldom brought on shore. It has been confounded with the variegated; but may at once be distinguished by the tapering of the body towards the tail, and more particularly by the union of the dorsal and 
anal fins to the base of the tail, while the variegated sole has the tail separated from them by a considerable interval.

The Brill, Pearl, Kite, or Bonnet-Fluke (Rhombus vulgaris, Pleuronectes rhombus; German: Der Glattbutt ; Dutch: Griet), is very similar to the turbot, but smaller, and of a more oval form. It is considered as inferior to the sole, but much superior to the plaice. It is a poor people's fish.

The two species of Topknot (Rhombus lintus, Pleuronectes punctatus), called "Muller's Topknot" and "Bloch's Topknot," are both somewhat rare, and seldom exceed 7in. or $8 \mathrm{in}$. in length. They resemble the brill in their roundish oval form. They prefer low shelving rocks, covered with seaweed, where they are not easily perceived.

Muller's Topknot is not an uncommon fish in the west of England. The largest examples seldom exceed 7in. or 8in. in length.

The Carter, or Whiff (Pleuronectes pseudopalus, Rhombus megastoma), is also called Mary Sole, Queen Sole, and Lanthorn-fish. These fish are rather difficult to diagnose; and I have been unable to get recent specimens to make them out perfectly.

The Scald-fish (Rhombus arnoglossus, Arnoglossus laterna) is one of the smallest of the British flat-fishes, its length not exceeding 5in. or 6in. It is exclusively confined to the southern coast, and is called there Megrim. It has obtained the name of scald-fish, because, when caught with the least possible amount of injury, it is found to have lost the greater portion of its scales, and it only requires a slightly rougher handling for it to suffer the loss of its skin also; so that the surface usually appears as if the fish had been dipped in boiling water. 
The Dab, Gray Flounder, Rock Fluke, or Sand Dab (Pleuronectes limanda; German: Die Kliesche; French: La Limande), is readily distinguished from either by its paler (light brown) colour, the abrupt and high arch of the dorsal line over the pectoral fins, and the roughness of its scaly surface, from which it has been called, in Latin, limanda (from lima, a file). It is also much smaller, averaging from $6 \mathrm{in}$. to $9 \mathrm{in}$. in length.

\section{THE FLOUNDER.}

German: Die Flunder, Sandbutt. Danish: Skrubbe. Dutch: Bot. French: Le Flet.

Iт inhabits every part of the British seas, and often frequents our rivers beyond the reach of the tide, thriving

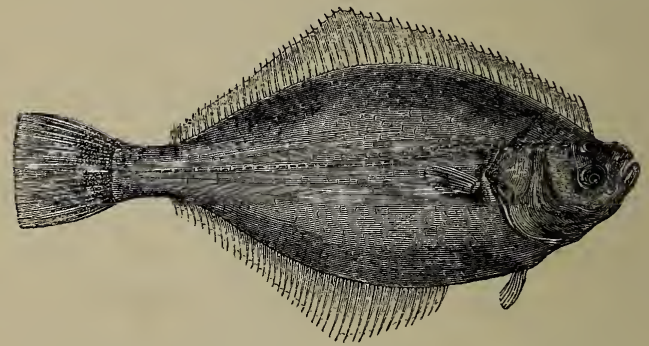

FLounder (Platessa flesus, Pleuronectes flesus).

in salt, brackish, or fresh water. Now that the Thames is getting purer, the flounders are, I am glad to say, returning to the river above London Bridge. The flounder is much smaller than the plaice, it is also more elongated in form, and has a row of sharp, denticulated tubercles, which surround its sides, and are placed along the base of the dorsal and anal fins. There are specimens without any colour on either side, specimens coloured on both sides, and specimens with both eyes 
and the whole of the colour on the left side, instead of the right; while white or Albino varieties, are not uncommon.

Anacanthini Airisomeri.

\section{HALIBUT.}

Pleuronectida.

\section{(Hippoglossus vulgaris.)}

German: Die Heiligbutt. Pferde Zunge. Dutch: Heilbot. Icelandic: Hejlagfiski Flydra. Norwegian: Legekveite. Swedish: Helgflundra. French : Fletan.

THe Halibut is decidedly a northern fish, being found on the coasts of Iceland, Greenland, Norway, Scotland,

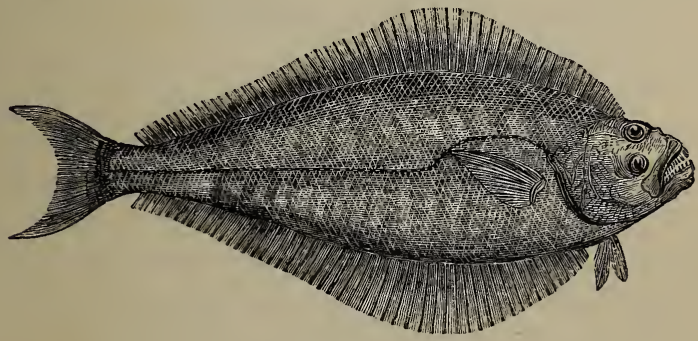

HALIBUT.

and the British shores of the North Sea: it lives and thrives on the immense sand plains between Scotland and Norway. These fish grow to an enormous size

In February, 1874, Mr. Dearsley, of 1, Russell Street, Covent Garden, sent for me to inspect a monster: halibut. The dimensions of this fine fellow were length, $6 \mathrm{ft}$. 3in., width, $3 \mathrm{ft}$. 1in., length of head, $1 \mathrm{ft} .9 \mathrm{in}$. Not being able to afford plaster to cast this magnificent fish, I took the outline in unbleached calico and a carpenter's pencil (a capital plan by the way), Mr. Searle then cut it out in wood and painted it to life, and it is now hanging up in my museum. This fish was caught off Montrose, Scotland. 
In March, 1869, Mr. Reid, of Wick, reported to me a halibut measuring $5 \mathrm{ft}$. 10in. in length, $2 \mathrm{ft}$. 10in. wide, and 7in. thick. At the end of February, 1877, a lalibut was landed at Wick weighing $2 \mathrm{cwt}$. $7 \mathrm{lbs}$, , or two hundred and thirty-one pounds, length $7 \mathrm{ft}$. 1 in. The Jews are excessively fond of halibuts; they mostly come to the London markets in the spring months.*

There is a great halibut fishery in British Columbia. Of this fishery the following interesting account is given in "Scenes and Studies of Savage Life," p. 225 :"The mode of fishing for halibut is 'long lining.' For some reason or other the natives will not use a steel hook in fishing for halibut.

"Their own halibut hook is curiously shaped, and is made of a stringy tough part of the Douglas pine, or the yew, which is steamed until it is flexible, when it receives its proper shape. The hook has no barb. The sides of the hook must be kept tightly bound together until the time of using.

"The lines are made of seaweed, except for six or eight feet from the hook, where they are of twisted twigs or deer sinew. To make seaweed into a line, it is soaked in a fresh stream, and the water being afterwards squeezed out with the hands, the line is rubbed with an oily cloth, and afterwards dried in the sun. Clams or small fishes are used for bait in fishing halibut. The fishing season is March, April, May, and June.

"Thousands of halibut, some of them weighing more than two hundred pounds, are caught by the natives and are exchanged for potatoes, gammass, rush mats, and other articles. The best fishing grounds are about twelve miles off the land; but the halibut is also

* Much valuable evidence relative to Halibuts is to be found in our " Report on Deep Sea Fisheries, 1879." 
caught near the shore. The fishing tribes on both sides of the straits of Fuca would drive away any other tribes which had not been accustomed to fish on the halibut banks. The mode of fishing is to trail the line slowly after the canoe, the hook being sunk in deep water. Hundreds of canoes, with two or three men in each, start at midnight for the fishing-ground, so as to arrive there in the morning. After half-a-day's work, if the sea is moderate, the canoes are quite laden, and the fishermen return. If the sea should rise during their progress to the shore, rather than throw any of their fish overboard, the natives tie large inflated sealskins to both sides of the canoe to increase its buoyancy. The hairy side of these skins is turned inside and the skinny side outside, and various rude devices are painted on the outside, such as the sinking of a canoe, or the capture of a great fish. To get so large a fish as a halibut into a canoe at sea is rather a difficult matter. Accidents, however, rarely happen, and the fish seldom gets away after being hooked. By using bladders attached to the line, and spearing the halibut when he appears on the surface, the largest fish is finally towed alongside the canoe, where he is killed by being struck on the head with a club."

\section{THE PLAICE.}

(Platessa vulgaris.)

German: Die Scholle. Danish: Röddspätte. Swedish: Tunga. Dutch: De Schol. French: La Plie Franche.

Mr friend Mr. Thomas informs me that there are two kinds of plaice-the ordinary plaice, which has no spots; and the diamond plaice, with spots. The latter is caught in May and June on the Brown Bank and the 
Well Bank, on the Dutch coast, and are superior to those caught in the earlier season of the year on the Doggerbank. The plaice is very prolific. In a plaice I had sent me by Messrs. Gilson and Quelch, of Bond Street, the fish weighed 4lbs. 15oz., the roe weighed.

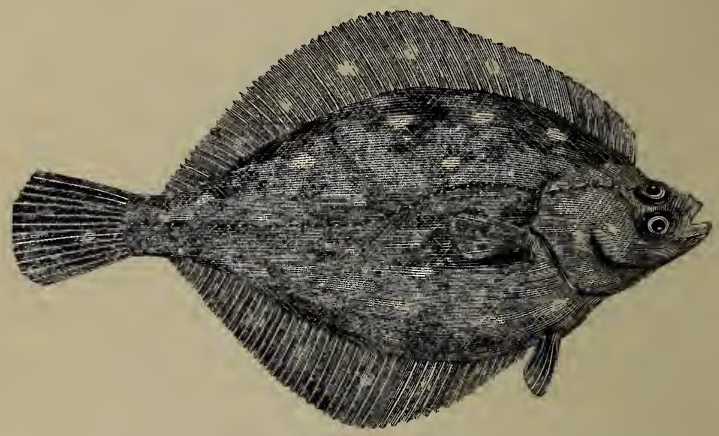

PLAICE (Platessa vulgaris, Pleuronectes platessa).

1lb. 9oz., and contained 144,600 eggs, but the eggs were of a large size compared with those of the turbot.

In October, 1869, I witnessed the drawing of a seine net opposite our oyster fishery at Reculvers, near Herne Bay, Kent, when a considerable number of plaice were caught; but just as the net arrived at the edge of the waves it "rolled," and nearly all the plaice escaped. A fisherman cried, "Look out, they'll sand!" a capital expression, for I found that the fish sunk into the sand with such rapidity that the operation must be seen to be believed. The plaice lifts up its head and the upper third of its body and then brings it down on the sand three or four times with sharp, quick raps; a small cavity is thus made in the soft, wet sand, which at once fills with water; the fish then works its fins on each side of its body with such a rapid motion that they seem 
almost to vibrate. These combined efforts enable the fish to conceal itself almost quicker than the eye can follow, and nothing can be seen but its eye, which is of a lovely emerald colour.

I now publish a very important letter I have received from an experienced North Sea trawler, which gives us very alarming news.

" To give you my opinion as to why there is a falling off in the supply of plaice and soles-and it is well known among fishermen that it is so to an alarming extentwhen we first went to fish off the Sylt about ten years ago, very near all the ground from Horn Reef to Heligoland was covered, as it were, with shoals of small plaice, and intermixed with these plaice a good many soles, both large and small. We have got as many as eighty baskets of small plaice and ten baskets of soles for one night when we first went there, and very near all the plaice would be thrown overboard, and you may be aware that they always die after they have been hove on board by a trawler. These fish are so small, that I have counted 250 in one basket, such as we use at Grimsby. The small plaice that are brought to London market are the largest picked out, and then the others are thrown away, and I would have you to remember they all die. Now, we have fished there every summer, heaving big bags of small plaice on board and throwing them away for the sake of the soles, till by destroying the young brood, full-grown plaice have grown very scarce, so that at the present time very small plaice will sell well. As the soles have grown scarce off the Sylt, the small plaice, being saleable, makes up; so you see they are bound tc be caught unless stringent measures are taken for their preservation. Twenty baskets is the most you would get for a night now. My opinion is that 
as the ground from Horn Reef to Langeroog, within a less depth tlian twelve fathoms, is a natural nursery for young brood, and that if the wanton destruction of it continues to go on as it has done, we shall soon find it extremely difficult to find even a moderate supply of full-grown plaice, but I have no doubt that if it were stopped soles would be more plentiful too. It is to the interest and benefit of every one in the fish trade that no trawlers should fish within the above depth and limits."

\section{THE TURBOT.}

\section{(Rhombus maximus.)}

German: Die Steinbutt. Danish: Pighvarre. Norwegian: Sandkero. Swedish: Butta. French: Le Turbot.

A LARGE portion of the Turbots sold in the various English markets is taken on or near the various sand-banks

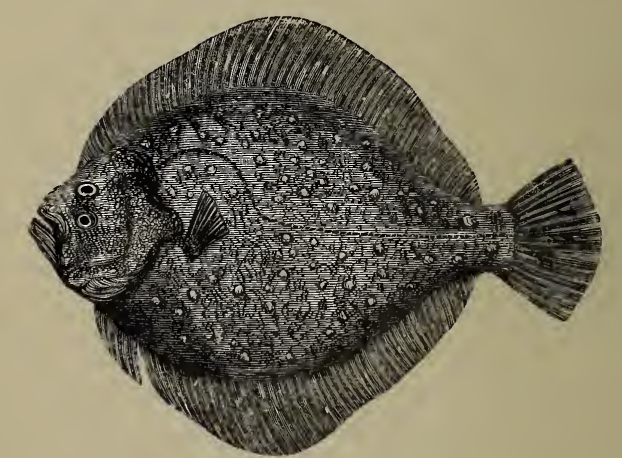

TURBot (Rhombus maximus, Pleuronectes maximus.)

between the long line of our eastern shores and the coast of Holland; the finest are taken upon the Flemish banks. At the beginning of the season the trawl-net is used, which, being drawn along the banks, brings up various kinds of flat-fish, as soles, plaice, thornbacks, 
and turbots; but when the weather has driven the fish into deeper water, the fishermen then have recourse to their many-hooked lines. All along our eastern coast turbot are caught by trawling and long-line fishing, and at particular seasons, on the Varne and on the Ridge-two extensive banks of sand (the first about seven miles, and the second about twelve miles from Dover) towards the French coast. The Folkestone and Boulogne passenger steam-boats go near these banks. Magnificent turbots are also caught at the back of the "Falls," near Margate; there are sands near the Goodwh which, however, the turbot do not frequent.

The turbot is particular as to the quality of his food: the bait used for him should be very fresh-if it happen to be in the least degree tainted, the turbot will not touch it. The most enticing baits are those small fishes very bright in colour. The Thames lampern was formerly used in large quantities by the Dutch, as they could be easily kept alive at sea, combining bright silvery colour with great power of resisting the usual effect of mutilation.

Large quantities of lamperns are now sent from the Severn and Trent to Great Grimsby and Hull for turbot bait.

The most common size of this fish varies from 5lbs. to $10 \mathrm{lbs}$. weight; occasionally it attains to 20lbs., and sometimes $30 \mathrm{lbs}$.

I have a coloured cast of a turbot in my museum which weighed $321 \mathrm{lbs}$.

The turbot is one of the most prolific fish known: one, which turned the scales at 23lbs., carried, I found, a roe weighing 5lbs. 9oz., and contained no less than fourteen million three hundred and eleven thousand two bundred eggs $(14,311,200)$. 


\section{THE SOLE.}

(Solea vulgaris.)

German: Die Seezunge. Danish: Tunge. Swedish: Tunga. French: La Sole. Italian : Sogliola.

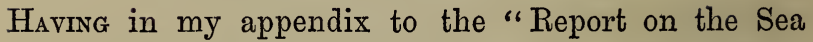
Fisheries of England and Wales, 1879" (c. 2449), given the result of my investigations on the natural history of the sole, I now give an abstract thereof:-

"To the London market, and to the British public in general, soles are the most important of sea fish. They are required by all classes of society ; the higher classes get those of the best quality, the poorer classes get the smaller fish.

"Very little is definitely known of the habits of the sole. During the spring, soles resort to banks and estuaries to seek their food and deposit their eggs, to the well-being of which the heat of the sun is absolutely necessary. In the winter they retire to great depths in the ocean.

"These two facts are of exceeding importance to the fishermen in the North Sea; for in the spring time of the year a great migration of the soles in the North Sea takes place towards the shallower water, which is undoubtedly their spawning place.

"The fishing ground for soles on the Dutch coast may be said to be about 278 miles long and 35 miles wide, and the season when the fleet is working on this ground may be generally said to be the spring and early summer.

"In April there would be 1,000 sail of smacks fishing from the Hook of Holland to the coast of Jutland.

"Along the Dutch coast there are several rocky 
places, and there is also a good deal of rough ground in the North Sea where the fish breed.

"This rough ground, where the trawlers cannot go without danger of breaking their nets, affords a 'sanctuary, as the Scotch deer-stalkers have it, for the soles.

"Soles also resort to the Dogger Bank probably for the purpose of spawning. They are caught there in large numbers in May, June, and July. That they probably spawn there may be concluded from the fact that very large quantities of little soles an inch or two long get jammed and killed in the ground ropes of the trawl net.

"When the winter season comes on, the soles in the North Sea take up their winter quarters (probably for hybernating purposes) in very deep water. The chief resort of soles in the winter months is the Silver Pits, a very extensive piece of deep water situated between the Dogger Bank and the Well Bank. The greatest depth is to be found at the west end, where there are fifty-six fathoms of water, i.e., 134 feet higher than the Monument.

"The soundings brought up from here resemble biscuit dust.

"The Silver Pits (first discovered, I believe, in 1843) are so called on account of the large quantity of fish which were caught when the pits were first discovered. Soles massed themselves together in these pits in a wondrous way, and fabulous stories are told of the sole fishery there.

"In the winter time the soles also resort to a locality called California, a small tract of coarse ground first discovered in 1847. The north end is about five miles from Flamborough. 
"Soles are also caught in considerable quantities on the south-east of the Brown Bank.

"The supply of soles is very fluctuating. One reason of this may be their migratory habits. Hence the great importance of keeping regular registers of temperatures both of air and water at times both of success and of failure. As an instance of the fluctuations of the catch of soles, P. Harman, a fisherman of Brighton, informed us that forty years ago he caught a quarter of a ton of soles in a night. A great body of soles came along off the coast which lasted for two months. There were never so many known before.

"A considerable sole fishery is also carried on from Brixham, in Devonshire, where there are now about 120 trawlers, from thirty to sixty tons each. The Brixham soles are known by the name of 'Torbay soles,' and are considered good. Sometimes large specimens are taken. I have a cast of a pair of soles from Torbay $22 \mathrm{in}$. by $11 \frac{1}{2} \mathrm{in}$. and $21 \frac{1}{2} \mathrm{in}$. by $8 \frac{1}{2} \mathrm{in}$. respectively. The largest soles $I$ have in my museum as casts are a pair from Ireland, weighing altogether 12lbs.

"Dover soles are also in great repute in some of the Midland markets.

"The sole has very fine and very pointed teeth on the lower jaw, and a number of very short and delicate barbules on the white side of the body around the mouth.

"On account of the difficulty I have had in obtaining the viscera $I$ have not been enabled to obtain many specimens of the food of the sole. I have, however, received good evidence that it feeds on the worm which forms the sandy material called ross. This ross is secreted by a worm called Terebella. It also decidedly preys upon rag worms, lug worms, the animals of serpula, and any minute shells it can pick up." 
EGGS OF SOLE-YOUNG SOLES SWIM ON ONE SIDE. 187

The eggs of the sole are very minute, smaller than turnip seed. According to my observations a sole of 1lb. weight carries eggs to the number of 134,000 .

When giving his evidence before my colleague, $\mathrm{Mr}$. Walpole, and myself during the Sea Fisheries Inquiry, at Mevagissey, Cornwall, Mr. Matthias Dunn (who for knowledge and observation of deep-sea fish may be said to be the successor of the late Mr. Jonathan Couch) told us in evidence thatj young plaice and soles when first hatched out always swam on their edge for about a week, and that in this condition they had their eyes upon different sides of the head.

In the spring of $1879 \mathrm{Mr}$. Dunn most kindly sent me living specimens, that I might verify his statement. An ordinary sole, as everybody knows, has a white side and a dark side. He always swims at the bottom, the white side down and the dark side up. He has two eyes; these eyes are both on the dark side, and both look upwards. The plaice is also the same. The living specimens which Mr. Dunn has sent me are about the size of a rice grain, only very thin and transparent; and, sure enough, instead of having both eyes (bright opalescent specks) on one side, they have one on the lower or white side, and one on the upper or dark side.

What is also most curious is that when the little fellows swim in mid-water, as they sometimes do, they do not progress with a waving serpentine motion, as do their fathers and mothers, but swim on one side moving their fins very rapidly; their mouth is then in the middle, and there is one eye on each side, just as in a "round" fish, such as the salmon, perch, \&c. I have gone fully into this curious point in the Deep Sea Fisheries Report, where I have also made the following remarks :- 
DESTRUCTION OF SMALL FISH BY THE MESH OF TRAWLS.

"It must be obvious to any person who examines the slabs of the fishmongers' shops that large quantities of small soles and small flat-fish are daily sent to market. T'his destruction of small fish, at first sight, seems a great waste of good food, and we cannot help regretting that these little creatures should not be allowed to grow up into fish of ordinary marketable size.

"The question will immediately be asked, Where do these small flat-fish come from ? The answer is, Mostly from the nets of the deep-sea trawlers. Why, then, are not immediate steps taken to prevent the destruction of young fry? This is one of the most difficult problems my colleague and myself have had to face during the inquiry, and my personal attention has been directed to it incessantly both out of doors and indoors since the inquiry began.

"In the first place, the very small fish which are captured-smaller than the smallest exposed for saleare no good to anybody. The captains of the trawlers do not want them; the fish merchants at the fishing ports do not want them; the wholesale merchant at Billingsgate does not want them; the retail fish merchants do not want them; they are a nuisance to the small fishmongers and costermongers; and, lastly, the fish-eating public do not want them.

"The obvious remedy for all these difficulties is to alter the mesh of net. Yet, simple as this may seem, it is a most difficult problem.

"Arriving at the fishing ground, the smack lets go her trawl, which, sinking to the bottom of the sea, begins to work the moment the vessel has any way on her. The trawl net is attached to the beam : the beam at 
each end is fastened to a heary iron runner, called the trawl heads; between the trawl heads is fixed a rope or chain, called the ground rope. As the vessel abore pulls this great net along the bottom of the sea the ground rope stirs up the flat-fish from the mud or sand and they are immediately caught in the funnel-shaped net behind them. The meshes of the net of a trawl net vary : the largest are close to the beam, the smallest at the ' cod end.' Into this cod end is swept everything that enters the mouth of the net. The trawl net is working at the bottom of the sea on the average six hours, and during this time it naturally collects not only fish, but sea-weed, stones, mud, etc.

"When the net is hauled on to the deck and the cod end opened to let the fish out, the little flat-fish are discovered jammed up tight among their larger comrades and the rubbish.

"The captain of the smack is unwilling to put them overboard, because they are dead; they are therefore packed with the other soles and sent off to London $\mathrm{Or}^{\circ}$ other markets.

"The fish merchant buys a 'pad of soles' without examining the contents. He afterwards finds little and undersized fish mixed with the marketable soles; he cannot sell them-they therefore are passed from one to the other, till at last they are sold to the poor people in penny or twopenny lots.

"The same thing occurs with other linds of flatfish."

The question of inventing a mesh of net that will let go the small soles, while it will retain the larger ones (and in my opinion no sole should be taken under $7 \mathrm{in}$. in length) is the greatest problem that we hare to consider in dealing with the future Sea Fishery question. This 
problem, I am sorry to say, is as yet far from being solved; whoever will solve it will be one of the greatest of benefactors to the English people, and would most assuredly deserve a reward not only from the smack owners, fish merchants, and trawlers, but from the public in general.

\section{THE POLLACK.}

\section{(Merlangus pollachius.)}

Local names: Laith, Leeat, Lythe Skeet, Whiting Pollack. German: Der Pollack, Tangwittling. Danish: Lubbe. Dutch: De Polak. French : La Merlan Jaune.

THe Pollack, or Lythe (Merlangus pollachius, Gadus pollachius), is a very strong fish: the colour is dusky brown, inclining to green in the upper parts; the sides and belly whitish; the under jaw projecting much beyond the upper.

The pollack is one of the commonest fish, and is found on all our coasts where the nature of the ground is suitable to its habits. Its haunts are upon rocky ground, and at no great distance from the land.

Acanthopteri.

\section{POPE, OR RUFF.}

Percida.

(Acerina vulgaris. Acerina cernua.)

Local names: Jack Ruff, Pope, Ruff, Tommy Bar. German: Der Kaulbarsch, Steinschwert. Danish: Horke. Swedish: Girs. French: Gremille.

Thrs fish is well known to Thames anglers, by whom it is often caught while gudgeon-fishing. A cruel habit, which probably originated in some idea connected with Roman Catholic persecution, is practised 
up and down the Thames, and, I believe, almost all over England. A wine cork is pressed tightly on to the spine of the dorsal fin, and the fish turned loose; this is what is called "plugging a pope." There are,

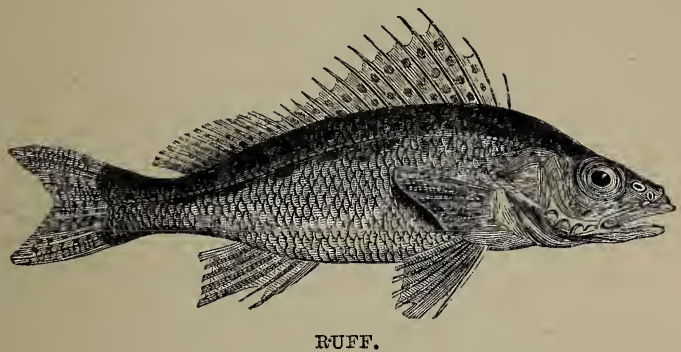

I believe, a great number of these fish in the Yare and Wensum. Mr. Searle tells me that they are plentiful in canal cuts in Berkshire, where there is a gravelly bottom, but not much stream.

Mr. Edon, the attendant at my fish museum, informs me that the Sheffield people, especially the artisans, are very great anglers, and that angling matches are often instituted, for which prizes are offered. These prizes are generally exhibited the night before the match, and consist of the funniest things possible, such as a sack of soot, a child's pair of shoes, a hay-fork. The next morning a special train is run to "fish off the match" in the Keadley canal, Lincolnshire, the station being Crewel Bridge, where competitors for the match, from Leeds, York, \&c., meet and join the excursion. Pegs are placed along the side of the canal ten yards apart, each peg being numbered, and the angler who draws the number on a ticket drawn from a big beer-jug must fish at the post corresponding to the number. Sometimes there are as many as five or six hundred competitors. 
I understand it is a common sight to see a forest of rods at the drawing of tickets, and also when the fishing commences, the row of rods extending sometimes three miles or more. On these occasions a great many popes are caught, and it is the invariable custom of anglers to carry bits of cork in their pocket, which they fix on to the back spines of the fish, which they let loose again into the water both during and after the match. It is a very funny sight to see the surface of the canal for so many miles covered by these unfortunate popes.

\section{THE POUT.}

THis little fish is also called the Bib Whiting Pout, or Bragay, also the Stink-alive, as it so soon losen its freshness. The pouts come in shore in June, and go away in September. The whitings come in November and go away in January. When first caught pouts are of a most lovely iridescent colour; they soon assume a dull brown-paper colour. By an ingenious process, pouts are frequently made to do duty for whiting. If a pout be taken out of the water and put in again, he "gets blowed" and can't swim, but floats on the surface till a "sea maw" gull whaffles him down.

Excellent fishing can be obtained near Portsmouth. In my " Curiosities of Natural History Series," 1866, I gave my experiences of pout fishing with my old friend Robinson Crusoe, a retired man-of-war's man. Here is a bit of the fine old sailor's yarn :-

"It's the pouts as likes the wracks (wrecks); they eats the little teeny long-pinchered crabs no bigger than my thumb-nail, and the sea wodlice, and such like; but a pout arn't particular like a conger or a whiting; and 
them heary whiting do bite 'logie' dull like; but it's a curious thing as any fish will eat boiled cabbage or boiled onions, and they comes about the ships at Spithead for it. I knows of seven or eight wracks hereabouts where I fishes. The Boyne is about as good as any of them. She was a fine ship was the Boyne. She catched fire at Spithead (I think it was in 1798), and all her arms was shotted; they went off one after the other right among the fleet. Her magazines was full of powder, so they set her adrift, and she took the ground in five fathom of water, just at the edge of the Horse Bank, and there she fired away 'till she blowed herself up, and she is now the wonderfullest wrack about here. There's a wonderful sight of timber, and a wonderful sight of fish about her, and they always runs good. I fishes at her all the year round, and yet there's always fish, though sometimes you can't get a smell out of them much less a bite. I once catched a hundred dozen of pouts in three bits of tide, and some of them was very fine pouts. The young flood is the time to catch 'em. Then they stops nearly an hour, and then comes in the whole body of the tide, but there ain't half so many pouts about as there used to be: it's the town gas as kills the fish. If a porpoise was to swallow one bladder of gas as big as a halfpenny as it comes out of Portsmouth harbour, he'd turn the turtle in a minute; it's real poison is gas."

Anacanthini Colades.

\section{REMORA.}

Is the Remora Suckers, the sucking apparatus is placed on the crown of the head, in the form of a large oval shield, by means of which the fish are able to attach themselves firmly alongside of other fishes, or 
to the bottoms of vessels; but whether for protection, or conveyance, or both, is a question which has not becn satisfactorily ascertained.

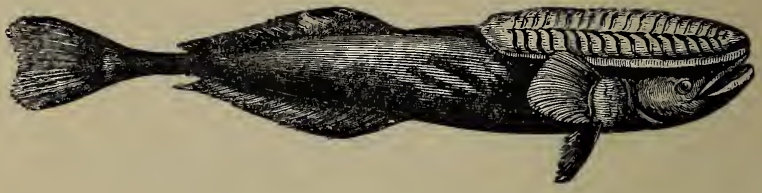

REMORA (Common remora, Echineis remora).

The sticking apparatus is thus described in the catalogue of the Royal College of Surgeons, specimen $2081_{\mathrm{A}}$ :-

"The suctorial disk, removed from the head of a larger species of remora (Echineis naucrates Linnaus). The disk is an oval flattened surface, composed of a series of transverse laminæ directed backwards, and denticulated or spinous at their posterior margin; the laminæ are movable, and when recumbent are raised and fixed on a foreign substance, a vacuum is produced in their interspaces, and the fish adheres firmly to the body to which the disk is attached, until it voluntarily retracts the circumference of the disk, destroys the vacuum, and depresses the laminæ, which then, from their peculiar arrangement, present little or no obstacle to the progress of the fish through the water."

Many of my readers are not probably aware that the remora has been used as the symbol of prudence. The great west window of New College Chapel, Oxford, contained seven allegorical pictures, after designs by Sir J. Reynolds, representing the four cardinal and three Christian virtues, namely, Temperance - with water and a bridle at her feet; Fortitude-in armour; Faith - with a cross; Charity - with poor children; 
Hope-with an anchor; Justice - with a steelyard and sword; Prudence carries " upon her right arm an arrow joined with a Remora, a fish that fixes itself to the bottom of ships and retards their motion." The arrow and the Remora are the respective emblems of quickness and slowness, Prudence being the medium between them.

\section{RIBAND FISHES.}

THIs family contains some of the most singular fishes in existence-those of the riband-shaped form. Covered with the richest silver, and of great length, the undulating motions of these creatures in the sea must be resplendent and beautiful beyond measure. But these wonders of the mighty ocean are almost hidden from the sight of man, since they appear to live only in the greatest depths, and it is but rarely, at long intervals, and after a succession of tempests, that specimens are cast upon the shore. No more than six species have been obtained on the British shores, and those but rarely. They are the Scabbard Fish, the Silvery Hairtail, Hawkin's Gymnetrus, and the Red Band Fish.

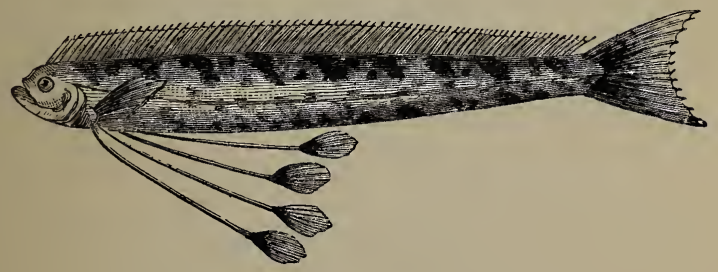

HAWKIN'S GYMNETRUS.

In April, 1872, Mr. Provcst Barclay, of Montrose, lindly forwarded me the following interesting information:- 
"An unusual visitor to our shores was captured this morning in Messrs. Johnstone's stake nets on the beach here, proving to be the Vaagmaer, or deal-fish (Gymnetrus arcticus), of the northern seas. The length of this splendid specimen is 6 feet; breadth, $12 \frac{3}{4}$ inches; dorsal fin, which runs from the back of the head to the tail, $4 \frac{1}{2}$ inches; greatest thickness of the fish, $2 \frac{1}{4}$ inches. The caudal fin has seven rays, which spread from a small centre like a fan, and the colour of the fins and tail are blood red; colour of fish silver-grey, and without scales; eyes golden and very large, being two inches diameter. This fish is described in Yarrell, but seems. to be but little known, and therefore inaccurately figured. Yarrell shows two spots on the sides which are not found in the specimen just captured, and spealss of ventral fins, but this has none."

At the end of July, 1877, I received, through the kindness of Mr. J. C. Traill, of Castle Hill, Thurso, N.B., a magnificent specimen of one of the rarest British fishes. Mr. Traill wrote me:-

"I send up by train from Thurso a box containing a. large fish, unknown here, which was washed on shore late on Sunday night. I only heard of it on Monday morning, and at once took possession of it, but not. before some mischievous people had cut off the tentacles, or long feelers, which I am told stood up from the head to the height of about thirty-six inches. You will see where they have been taken or broken off. The fish was also broken in three pieces near the tail, in the attempt to roll it up before I got it. When the fish came ashore it was alive, but must, I expect, have been in a dying state, as the weather was quite calm and the sea quite smooth. The beauty of the fish consists in its colour. I don't know how it will appear when it gets 
to you, but you can form no idea of the brilliancy of its appearance when it first came ashore. It was all over exactly like the reverse side of a looking-glass, and for a quarter of a mile off could be seen shining on the sands like a mirror. The men's fingers, in handling it, were covered over with what was exactly like prepared silver paint, manufactured like Bessemer's gold paint, which artists' colourmen sell. I think I see signs of tentacles below the bead, as well as above, and there is a fracture at the end of the tail, which almost looks as if that portion of the tail, which was furnished with spines, as in the drawing, had been broken off, or eaten off, before the fish came to land, and may, in fact, account for its being cast ashore, as it would be like a boat without its rudder or powers of sailing from the stern. My house is distant about five miles due east of Thurso, and is on the shore of the Bay of Dunnet, which you will see marked in Black's maps. It is a beautiful bay, with a fine sandy bottom, about three miles across, with bold, rocky coast on the other side, but a smooth, sandy shore shelving out to sea very gradually, until you get to the opposite headland. I have no doubt, if I had the proper appliances, many rare and beautiful fish could be taken in this bay. These must be frequently carried across the Atlantic, and take refuge here from the racing tide of the Pent. land Firth."

On removing the lid of the box, there appeared a most magnificent specimen of Gymnetrus arcticus, otherwise Regalacus banksii. It had been packed in ice, and was in good condition. "When spread out it measures 12ft. 4in., and is much in the shape of an enormous sword tapering off at the tail. The head is unfortunately considerably smashed, but still the outlines are 
sufficiently apparent to enable us in some manner to restore it. The back is studded with sharp webbed spines forming a continuous back fin. The belly is covered with little ivory studs; the body is excessively fragile, and breaks up into small portions like overcooked meat."

Mr. Searle and myself made two casts of it, which are now in my museum at South Kensington. To preserve this huge fish in spirits would be impossible.

Mr. Bartlett tells me that he has seen in the Bergen Museum, Norway, a specimen of the same species, but. of smaller size than that sent me by Mr. Traill.

A correspondence took place on this subject in Land and Water (vol. xvii., Jan. to June, 1874).

My friend Mr. W. Reid, of Wick, gives the following: valuable information :- "Mr. Buckland mentions that only one vaagmaer is recorded as having been found in Orkney. While I resided in these islands I procured no less than three specimens, two of them in perfect condition (a thing very rare, I admit), the other sadly mutilated by sea-gulls. The two specimens-one measuring $4 \frac{1}{2}$ feet, the other about a foot less-I preserved for a local museum, which we had started some twenty-five years since in Kirkwall. I made a drawing of one of the fish at the time on tracing-paper over the body of the fish, and it gave an excellent idea of the size and outline of this very curious-looking species. Couch had commenced publishing his 'British Fishes' about the time, and I sent the drawing to him, and I believe that. it was from it that he figured the deal-fish in lis. excellent work. I enclose a diminished copy of the same drawing, which, I believe, will correspond with Couch's, although I have not the work to refer to. Knowing that the deal-fish had been picked up in some 
of the north isles of Norway, I wrote to several parties to be on the look-out for specimens to send me, and the three mentioned above were the result. Along stretches of sandy bays, where these fishes are found occasionally after storms, it is difficult to get hold of a good specimen. The lesser black-backed gulls, being ever on the watch at such places, seeking what they can devour, are always in at the death; and as the fish is as thin as a deal-hence its Orkney name, dealfish-and are very tender, they are soon mutilated."

I well recollect going with my father and Sir Robert Peel to inspect a so-called "sea-serpent" which was exhibited in Regent Street. This creature was figured in the Illustrated Nerts, June 2, 1849. By the courtesy of the proprietors of that journal, I have hunted up the number in which the figure and description is given, as follows :- " Annexed is the 'presentment' of the rare fish caught off Cullercoats on March 26, and exhibited for a short time at Newcastle-upon-Tyne. It proves to be a fine specimen of the Regalacus glesne, of the family of ribbon fishes, so named from their flat form. The fish when taken was as bright and shining as the newest silver; but after its death the beautiful iridescence left it. It was stated that the length of this specimen was 12 feet 3 inches; immediately behind the gills $8 \frac{1}{2}$ inches in depth; greatest depth, $11 \frac{1}{2}$ inches; greatest thickness, $3 \frac{1}{2}$ inches."

\section{HAIRTAIL:}

SILvERy Hairtail (Trichiurus lepturus). This beautiful fish used to be considered very rare, and only two imperfect specimens are mentioned by Couch. Nevertheless, on the 7th of December, 1870, I had no less than 
four silvery hairtails at one time in my dissecting-room in Albany Street. They were presented by Mr. Clegg, of Looe; Mr. Matthias Dunn, of Mevagissey; Mr. Charles, fishmonger, of Arabella Row; and Mr. Frank Gosden, fishmonger, of Exeter. These fish averaged $2 \mathrm{ft}$. or $2 \mathrm{ft}$. 8in. in length. I have fully described the Silvery Hairtail, in Land and Water, Dec. 17, 1870.

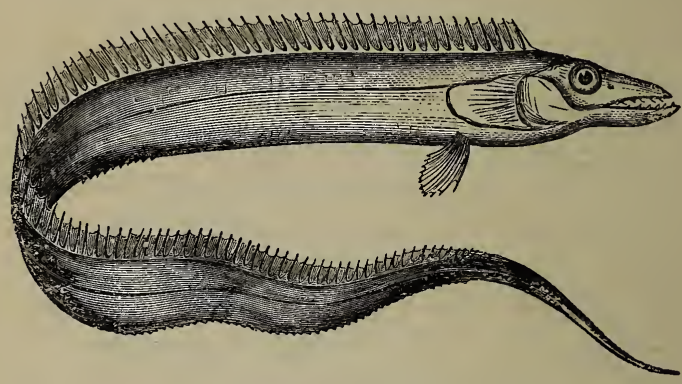

SILVERY HAIRTAIL.

In general appearance the hairtail is not unlike the common gorebill or gar-pike, if the reader can imagine this fish to be flattened out at the broadest part. It is 2 inches in width. The total length is 2 feet 4 inches. There is a fin like a perch's crest running down the whole of the back. This is 1 foot 5 inches in length, and about an inch wide at the broadest part. The colour is a beautiful silver, and there do not appear to be any scales. At about two-thirds from the head the body begins to taper, and gradually runs off until it becomes almost as fine as a horsehair, hence its name, trichiurus, from two Greek words signifying "hair" and "tail." The mouth, in general appearance, is not unlike that of a mackerel. The lower jaw projects considerably beyond the upper jaw, and the upper 
jaw fits into a niche in the lower jaw, so that when the fish is going through the water the peculiar shape of the two jaws will not obstruct its progress. Upon the extreme end of the upper jaw are four teeth, recurved and not unlike a snake's fangs in general appearance. The tips of these teeth are transparent, and, what is exceedingly curious, I find these tips are barbed on their posterior aspect like a fish-hook. When the mouth is shut, these teeth fit into a cavity in the lower jaw, and the tongue is prevented from being injured by their sharp points by means of a valve of skin, which is stretched across from side to side of the lower jaw, and then runs upwards; so that the top of the tongue is really encased in a convenient guard, not at all unlike a finger-stall made of an old glove, as applied to the finger of a human hand. On the mystache, or superior maxillary, there are a considerable number of very sharp lancet-like teeth on each side. They remind me very much of the shape of the teeth of the leech.

The lower jaw also contains similar teeth, which are larger towards the angle of the mouth than towards the symphasis or junctions of the arms of the lower jaw. In fact the whole of the dental apparatus of this fish is of a most formidable character.

These terrible cutting (and I might almost say prehensile) teeth are about a quarter of an inch long; the general form of the teeth would give it great swimming velocity. I cannot, therefore, help thinking this fish is one of the enemies of some small kinds of migratory fish, such as anchovies, for a more beautiful living machinery for catching these small and active fish could not possibly be devised. 


\section{SCABBARD FISH.}

(Lepidopus tetradens, argyreus, or caudatus.)

The Scabbard Fish is a large fish. A specimen pre served in the museurn at Penzance, caught twelve miles from land, measured 5 feet 4 inches. The colour above was greenish, with a tint of blue; but it is probably also iridescent when first caught. It is called the scabbard fish from its sword-like form and four elongated teeth in front.

I have a very fine specimen (dried) in my museuin, also a cast, length 4 feet 1 inch, and $2 \frac{1}{4}$ at the widest part. Teeth in lower jaw lancet shaped, and very pointed; four teeth in anterior portion of upper jaw, each barbed at the end like a fish-hook. It was presented to me with a number of other Mediterranean fishes by Mr. Stacey Watson, of Great Yarmouth. See Land and Water, Sept. 6, 1879.

\section{ROCKLINGS.}

T'aere are three species of Rockling (gents Motella). The Three-bearded, sometimes called Whistle-fish, bears some resemblance, in its bearded mouth and general appearance, to the common loach, or beardie, and is therefore sometimes called Sea-loach; but it is mucls larger, averaging from a foot to eighteen inches in length. The colour is a rich yellowish brown, marked with large dark spots. It keeps in shallow waters, frequenting rocky ground well furnished with seaweed, among which it threads its way with great ease and rapidity. It will take a bait, but is rarely eaten. "It is not easy to explain the uso of the fringed mem- 
brane behind the head and before the dorsal fin; it has nothing in common with the fins; but when the fish is

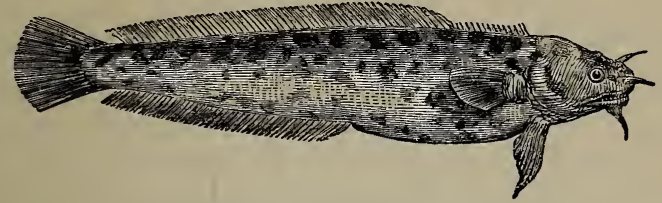

THREE-BZARDED ROCELING (Mustela vulgaris, Motella vulgaris).

lying perfectly still, and all the fins are at rest, it is often in rapid motion. The barbules on the upper jaw are always extended in front."

In August, 1867, a specimen was taken off Folkestone in thirty fathoms of water, which is said to be a very great depth for this fish. It measured eighteen inches. It is called a "goss" by the Folkestone fishermen. The specimen is in my museum. Another example was sent me from Penrhyn, Bangor, in December of the same year. The local name there is " the St. Mary's trout." Yarrell mentions 19in. as the length of the largest he ever saw. Strange to say, this specimen measured 19in. I cannot understand why it should be called "St. Mary's trout," except that the 8th of December is the Feast of the Conception, and the monks of old living near the sea generally had a "fishing weir," and " fixed engines" without end to supply fish for the fast days. Possibly these fish came from the deep sea about December 8th, and were hence called " St. Mary's trout" by the monks of Bangor Cathedral, founded A.D. 525 .

The Five-bearded Rockling (Gaclus mustela, Motella mustela) is much more common than the preceding one, and is met with on most parts of the British coasts. 
It closely resembles it, but has two additional barbules on the upper lip. The general colour is dark brown, sometimes with a bronze lustre, the belly whitish, and generally it is without spots.

Mr. Couch gives an interesting account of the nest made by this fish: "The nest is invariably formed of the common coralline (Corrallina officinalis), put together without skill or arrangement, thrust into some cavity of a rock close to the low-water mark, and the materials are maintained there by no other bond than that of compression. This coralline is sometimes not found within one to two hundred feet of the selected spot; it must be gradually collected and brought with a great degree of perseverance. The eggs are not contained in the cavity like those of the stickleback, but scattered through the mass of coralline." I am very anxious to get one of these nests.

The Four-bearded Rockling (Gadus cimbrius, Motella cimbria) is perfectly distinct from the two others, having three barbules on the upper lip, and another on the chin, and a long projecting filament in front of the first dorsal ray, which has a striking appearance. Its length is nine or ten inches, and it is found in the Firth of Forth and the neighbourhood.

\section{ROACH.}

Abdominales Malacopterygii.

Cyprinida.

(Leuciscus rutilus.)

German : Die Plotze, Die Rothauge. French : Le Gardon blanc, La Rosse. Swedish: Sarf.

Here is a French angler's opinion of the Roach: "The roach is by character inclined to controversy and is in- 
decisive in his conclusions. Sometimes he will bite, sometimes he will not bite; one never knows the reason why. To catch him the fisherman must have a subtle eye and a steady hand. One should take all sorts of precautions, for if he is curious he is also at the same time excessively suspicious. He is afraid of every float that is the least bit too big, so that to catch him one must use the finest possible tackle."

It is for this reason that roach fishing is such a favourite sport among anglers. When Assistant-Surgeon in the 2nd Iife Guards at Windsor, I was taught the art of roach fishing by $\mathrm{Mr}$. Pace, then Regimental Messmaster, than whom a better roach fisherman never existed. Our best sport was obtained in the autumn months, from September to Christmas.

There is a science in everything connected with roach fishing, from the making of the "ground bait" to the cooking the fish. The best ground bait was prepared for us by the mess cook; it was made of bread and bran, well mixed together, pounded in a mortar, and then boiled to a certain consistency. Sand was then mixed up with it, the quantity requisite being adjusted to the rapidity of the water in the "swim" we were about to fish. It was necessary the ground bait should collect the fish at an exact distance from the top of the rod, for if it was too near or too far from this point the "swim" would be spoilt.

Gentles are without exception the best bait for roach, but any kind of gentle will not do, it must be the gentle of the butcher's blue-bottle fly, and must be grown and fattened upon sheep's liver, nothing else will do. It is very difficult to keep these gentles throughout the winter, when they are most wanted, as they are very apt to convert themselves, if kept too warm, into 
chrysalids, and it has happened to me more than once to find all my gentles had become biue-bottles, which of course were useless. The only way to keep gentles from turning is to bury them in pickle bottles in the ground. When there are no gentles to be had I recommend boiled wheat. Gently boil the wheat over a slow fire until it gives out a jelly, the kernels will have cracked down one side; into the top of this crack insert the hook.*

The tackle we used was of the very finest. A single hair is very much better than the finest drawn gut; the best hair, for roach fishing known is the long peculiar coloured hair from the tails of Her Majesty's creamcoloured state coach horses.

There are many works written especially on roach and roach fishing, and I especially recommend the work of Mr. Greville Fennell, the well-known authority on angling matters, published by Longman, Green, and Co., London, "The Book of the Roach." The largest roach seldom exceeds 2lbs. : I have had roach brought to me heavier than this. In some cases they were hybrids; in one case, certainly, the fish was simply a bream.

The roach is subject to a curious disease which shows itself in numerous black moss-like spots growing on its scales. Mr. Henry Lee has examined these microscopically, and reports that this appearance is caused by an abnormal condition of the pigment cells, and the formation of a melanoid cancerous growth.

* See able article, " The Old Roach Hole,' by A. R. H., Fishing Gazette. 


\section{THE AZURINE, OR BLUE ROACH.}

\section{(Cyprinus caruleus.)}

THrs is a very rare fish. I have never had the luck to see this fish. It is not however uncommon abroad, I believe, and is mentioned by German writers on angling.

\section{RUDD.}

(Scarilinius erytroptha7mus.)

Local names : Finscale, Red-eye, Roud, Rudd, Shallow. German: Das Rothauge. French: La Rotengle.

Tне Rudd (Leuciscus, or Cyprinus erythropthalmus), or Roud, as it is known in the Norfolk vernacular, is very plentiful in the Norfolk broads, and especially those north-west of Yarmouth. Their colour varies much. In some shallow broads they are of a bright golden hue; in others, where the water is deep, their scales are like those of a roach or dace. A small red worm, gentles, and a paste made with honey and flour, will sometimes be taken freely when all others fail.

In Land and Water, vol. xviii., August 8, 1874, my friend, Dr. Norman, gives the following valuable experiences relative to Rudd fishing in Norfolk: "The best bait is a nice red worm, but the finest fish are taken with a salmon gut foot line and three hooks, a large float, and at least forty yards of strong light line. I have had a brace weighing nearly five pounds several times on my paternoster, and many years ago caught twenty-nine in a few hours, scaling over four stone. The ground should be very carefully baited for two days at least, and a long willow wand stuck in the mud in the middle of it. Anchor the boat very quietly twenty- 
five or thirty yards off, throw your float near the willow, and you will have such sport as few will imagine. It is really a case of no sooner in than under; and, as an old piscatorial friend said, after an hour's hard work, - Even in my wildest dreams, doctor, I never had such splendid fishing.' I once took three at a single cast of the line that weighed over five pounds, and a very pretty commotion they made in the water. Another evening, after a very early tea, we landed no less than 194. Sunrise and sunset suit these fish best, but I have had capital sport on a hot autumn day, although that is rather rare."

For the most part the rudd frequents the same districts as the roach. One diagnostic point between these two fish is as follows: In the dorsal fin of the roach it will be found that the front ray stands almost. even with the front ray of the central fin, but in the rudd the dorsal fin stands evenly between the anal and ventral fins. The eye in the rudd is of a much brighter red than the roach.

\section{SAND-EEL, OR SAND LAUNCE.}

Apodes.

Ammodytida.

German: Der Sandaal, Der Tobias fisch. French : L'Equille.

There are two species of the Sand-Eel, or Launce, the one much rarer than the other; this is the Wide-mouthed Launce, Horn Eel, or Sand-Eel (Ammodytes tobianus), which is much the larger of the two, measuring from ten to fifteen inches. The head is also much longer, and particularly the lower jaw. The habits of the two species are very similar. By means of the horn-like elongation of the under-jas they are enabled to scoop 
their way into the wet sand of the sea-shore, where they take refuge from the fishes which pursue them. The generic term (Ammodytes) refers to this power of digging into the sand.

The Small-mouthed, or Sand Launce (Ammodytes lancea), is a well-known fish, very abundant on almost all the shores of Great Britain and Ireland. It is much smaller than the other species, seldom exceeding seven or eight inches. On account of its silvery brightness, it is in great estimation and constant use with fishermen as bait for their lines. With the projecting under-jaw, aided by the muscular power of the fish and its slender form, it is enabled to bury itself very rapidly, five or six inches deep, in the soft sand as the sea retires, and then releases itself again on the return of the flood-tide, apparently quite uninjured, although it has been out of the water for some hours. When it is discovered that a shoal of sand-eels have hidden themselves in the sand, sea-side visitors should sally out, armed with spades, shovels, rakes, and forks, and dig them out. When extricated from the sand-beds, the fish leap about with singular agility, and afford much sport. Perhaps the fun in catching them has originated the saying, "As jolly as a sand-boy." When taken, they are frequently used as food, and are well-flavoured. Immense numbers of them are caught in the seine nets at the mouth of the Teign, Devonshire. They are much used as bait for basse-fishing with the rod. Mr. Hearder, of Plymouth, has made a very excellent artificial sand-eel of spiral india-rubber. 
Abdominales Malacopterygii.

\section{SHAD.}

Clupeida.

Mr. Couch figures three kinds of Shad-Allice shad (Clupea alosa, Alosa vulgaris), Alewife, Damin herring (Scadina).

Twaite shad or Maid (Clupea alosa, c. finta, Alosa finta).

Scalefinned shad (Alosa squamopinnata).

The Twaite shad (German: Der Finte Lachstaparre; Danish: Stamsild; Dutch: Fint) is a migratory species, ascending large rivers in the month of May, or earlier, and returning to the sea about the end of July. The shad are said to thrash the water with their tails, and on a calm still evening, or night, the

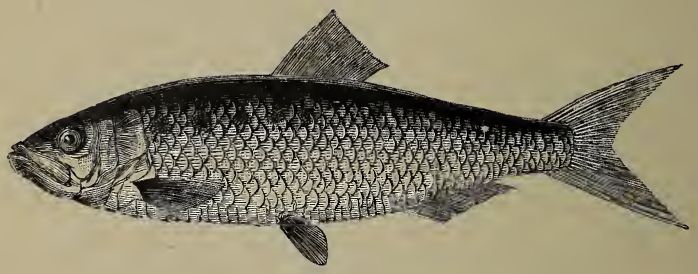

TWATTE SHAD (Clupea alosa, Alosa finta).

noise they make may be heard at some distance. The twaite is distinguished from the other native species by its having distinct teeth in both jaws, and by a row of dusky spots along each side of the body, while in the allice shad there is only one, and that close on the side by the upper part of the gill cover.

The Allice shad (Clupea alosa, Alosa vulgaris; German: Der Maifisch, Alse, Else; French : L'Alose) is very local, abounding in the Severn and Wye, but much less known elsewhere. The flesh of this species is said to 
be of superior flavour to the former, and to improve the higher the fish ascends the river.

Mr. D. Miller, who has an extensive shad fishery at Newnham, near Gloucester, in the Severn, has given me the following interesting particulars :-

"The shad fish season begins late in April, about the 15 th to the 20th, according to the heat of the season. If cold winds blow it begins later on. They are changeable, but the small cocks come first, so small that two are only equal to one hen. I know of only one sort of shad fish. The young cock is smaller than the hen, and comes rather earlier, but the big cock, or real shad fish, is this season later in coming by a week, viz., June 20 or thereabouts. The wholesale price is changeable. In the spring the price is six shillings per dozen, owing to the smallness of the cocks ; later on four shillings per dozen, as one hen counts for two cocks, and thirteen to the dozen. Our market is in the locality of Gloucester and Dean Forest, east and west; also a few have been sent to London this year, and other local markets nearer home. I think they spawn on the sands in the Severn, at least I have heard old fishermen say so. The young are seen in great numbers in the shallow and easy waters, at or near the close of the season, in a warm time. I think the large shad is generally an old cock in the Severn; but I have seen the same species occasionally in the river Tay forty years ago or more."

\section{SHARKS.}

THE White Shark (Squalus carcharias) is a powerful fish, most numerous in the tropical seas, but also abundant in the Mediterranean. As it is a great wanderer, it 
is not surprising that a straggler is now and then seen off the British shores; but the instances of its capture are few. It reaches the length of twenty-five feet, and is of an ash colour above, and whitish beneath. It swims with great ease and swiftness, from the size of its pectoral fins, and the strength and expansiveness of its tail. The nostrils are large, and it scents its prey at a great distance.

The Blue Shark (Squalus glaucus; German: Der Blane Hai; Dutch: Toonhai; French: Squale bleu) arrives in English seas about the middle of June. He feeds upon sardines, herrings, and mackerel, and often does terrible mischief to the nets. He passes up and down the nets, and often when tearing the fish out of the net cuts out great pieces of it with his sharp scissorlike teeth. Sometimes he rolls himself up tightly in the nets ; on such occasions the fishermen bless him.

The pectorals are long and pointed, the back is slate blue, as also are the superior surfaces of the pectorals and ventrals. The rest of the body and fins are white.

In September, 1868, Mr. Climo, of Fowey, informed me that a blue shark, $8 \mathrm{ft}$. 3in. long, and supposed to weigh 2 cwt., had been caught with hook and line by some pilchard fishermen.

The Greenland Shark (Squalus borealis, Scymnus borealis, Dalatias microcephalus), a native of the northern seas, has been observed on our coasts; the oak kettle of Iceland cod-men. An account is given of it in Dr. Scoresby's "Arctic Regions." It is $12 \mathrm{ft}$. or 14ft. in length, sometimes more; and its colour is ash-grey. This shark is a great foe to the whale, which it bites and annoys while living, and devours when dead. Insensible to pain and tenacious of life, as are all the larger sharls, this species is pre-eminently so. An 
external wound seems to have no effect on it. The Greenlanders eat its flesh, both fresh and dried, and make ropes of its rough skin. Its eyes are often infested by a parasitical insect.

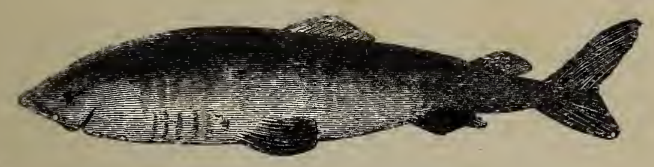

GREENLAND SHARK.

Captain Gray, of the whaler Eclipse, tells me these fellows soon assemble when he is cutting up a whale alongside the ship. They will eat quantities of whales' blubber, but on these occasions never attempt to snap at the men at work on the whale's body.

On the coast of Norway there are regular fisheries for these sharks, carried on for the sake of the livers, out of which oil is made. They are caught on lines mounted on very large reels with a double-handed handle, the line running over a pulley; the hook is of peculiar construction, and mounted on chain; the bait is a bit of rancid bacon or of porpoise or whale fat.

Not very long ago a shark was caught at Elgin, in Scotland. A correspondent there kindly sent me a note as follows: "From the description given, this fish is the Greenland shark (Scymnus borealis); it belongs to the family Lamnida, and is the Scymnus microcephalus of some authors. It is not confined to Greenland, as the name would imply, but possibly so named from being familiar to whalers in those seas. It is widely distributed in all the Polar seas, but is seldom seen so far south as the northern islands of Scotland. On the British coast its maximum longth has been given as 
13ft., so that the Lossiemouth fishermen have captured an unusually large one. It is exceedingly common on the north and east coasts of Iceland, and is known there as the hakarë. In the Iceland seas its average length is from $17 \mathrm{ft}$. to $19 \mathrm{ft}$., but attains at times a length of 24ft. Its liver yields about seventy gallons of oil. Unlike the other northern sharks, who feed principally on small fish, crustaceans, and jellyfish (Medusa), the: Scymnus attack and tear all sorts of cetaceans and phocædians, and devour the dead floating carcases of every sort of animal that may come in their way-horseflesh proving a very attractive bait wherewith to catch them. They even consider one of their own species a 'dainty dish.' The body of the fish, besides being eaten by the Icelanders, yields oil, but small in quantity to that produced by its liver, and far inferior to the same in marketable value. Shark fishing is prosecuted to a considerable extent in Iceland in small-decked fore-andaft rigged schooners, the oil being exported to the European continent. The shark fishing stations in Iceland where the oil is prepared are a novel sight to tourists, but on a visit I found them far from inviting. They were redolent of questionable scents, the putrid flesh or fish of the sharks lying scattered about in all directions." Our correspondent adds, "the writer in the Elgin paper clearly indicates the species, but it is much to be regretted writers in local papers do not endeavour to give the scientific name of any rare find. Popular names frequently differ in different localities, while not unfrequently the name given in one locality to a particular species is in another applied to a different species, or to a different fish altogether."

The Basking Shark (Squalus maximus)- named Basking from its remaining at the surface of the water 
almost motionless-is by far the largest of our native fishes. It is the "sun-fish" of the west coast of Ireland fishermen.

In September, 1868, a gentleman wrote me, saying, "A basking shark has been washed ashore on the north-west side of Achill Island; length, 27ft.; $12 \mathrm{ft}$. round at largest part; pointed snout, and gills in slits; teeth half an inch long, set in six rows. Inside the mouth were several rows of short black bristles; the skin coarse and rough. The liver contained a quantity of oil."

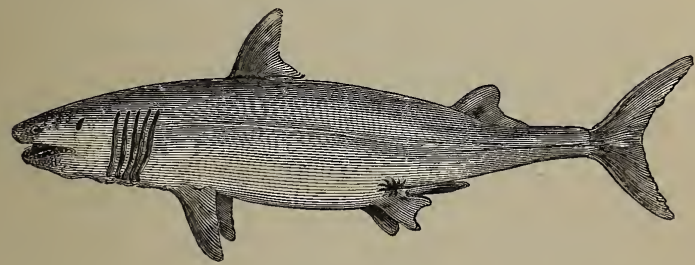

BASKING SHARK.

In March, 1875, I received intelligence from $\mathrm{Mr}$. $H$. Hadfield, of Highcliff, Ventnor, Isle of Wight, that an exceedingly large shark was ashore on the ledge, about half a mile to the westward of Shanklin Chine. The dimensions of this fish were-length from snout to end of tail, 28ft. 10in. ; circumference of body, 15ft. ; head, 6ft. 10in. in length; upper jaw, 3ft. 2in. ; lower jaw, $2 \mathrm{ft}$. $4 \mathrm{in}$. I was very anxious to make a cast of this fish, but the expense was too heavy for me.

The British Museum, however, being possessed of more money than myself, bought this shark, and on its arrival Mr. Gerrard, the Articulator to the Museum, kindly invited me to examine the skin. This skin weighed 1 ton $1 \frac{1}{2} \mathrm{cwt}$., and we calculated that the fish, 
before it was slinned, weighed about 8 tons. I regret that no record was taken of the size of the stomach, state of the viscera, \&c. The eye, when taken out of the orbit, wos as large as the two fists put together; the nose was composed of a gelatinous substance, as may be seen in common sharks and ordinary dog-fish. The sclerotic coat was as hard as though it was made of iron; the use of this is to prevent the soft structures of the eye being crushed by a superincumbent weight of water pressure, which at great depths in the ocean must be very great. Lying about among the cut off flesh of the shark I discovered two gills, which present a structure entirely new to me; instead of presenting the ordinary appearance of fishes' gills, they are exactly like fine fibres of split whalebone, only very brittle. These fibres also very much resemble bass, of which brooms are made. The length of these is $5 \mathrm{in}$. to 6in., and have a very pretty comb-like appearance. I cannot conceive how this structure can be adopted for oxygenating the blood. The teeth are remarkably small ; they do not in the least resemble the sharpcutting, triangular-shaped teeth of ordinary sharks, but consist, on the contrary, of six rows of little spikes. Mr. Searle and myself cut out the dimensions of this monster shark in board, and the same can be seen at my museum at South Kensington.

Mr. Brabazon states: "If the sun of April is hot, the Sun-Fish (locally so called) are certain to show above the water, and they remain on the Clew bank until the middle of May. A large shoal of sharks pass annually at this season along the west coast on their way from the southern to the northern seas. They are taken on the sun-fish bank, situated about a hundred miles west of Clew Bay, and extending many miles 
north and south. The fishermen there reckon it a day's sail out of sight of land. They are found on the bank in great numbers, and the large dorsal-fin is seen at a great distance, as it rises three or four feet out of the water while they lie motionless basking in the sun."

The Porbeagle (Lamna cornubica; German: Der Häringshai; Danish: Sildehaa; French: La Lamie

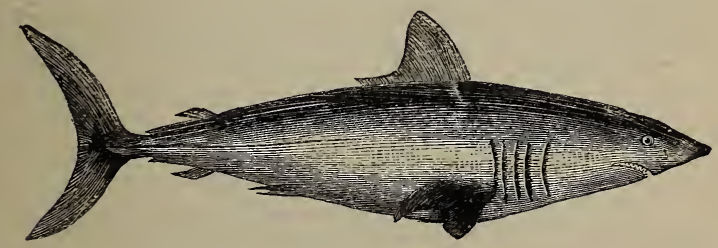

PORBEAGLE SHARK.

Nez) has a very pointed nose; teeth lancet shaped, not dentules. He has a keel-shaped ridge each side of the tail, the lobes of the caudal fin are nearly equal. His head-quarters seem to be the Gulf of Gascony and the north coast of Spain. He is a common visitor on the western coast in summer, and not unfrequently it wanders along the eastern borders of England and Scotland. Mr. Couch writes: "It usually proceeds in small scattered companies, preying on pilchards and herrings, and other small fishes that abound. The teeth, which present a formidable array of spears, are less formed for cutting than for seizing and holding its prey; which, therefore, it appears to swallow whole. I have found the remains of cartilaginous fishes and cuttles (Sepia) in their stomachs; and in one instance three full-grown hakes."

As they are caught in salmon nets I think it very 
probable that they hunt the salmon also, and the wounds we often see upon the salmon may be the marks of this shark's teeth.

In March, 1880, a porbeagle was taken at Wick, and Mr. Reid wrote me: "Our fishermen caught a fine specimen of this shark last week in their nets; it measured $7 \frac{1}{2} \mathrm{ft}$. in length; there was nothing in its stomach of notice. It was carted away for manure after the liver was taken out."

In September, 1867, Mr. Gerrard, Articulator to the British Museum, informed me he had a porbeagle, mea-

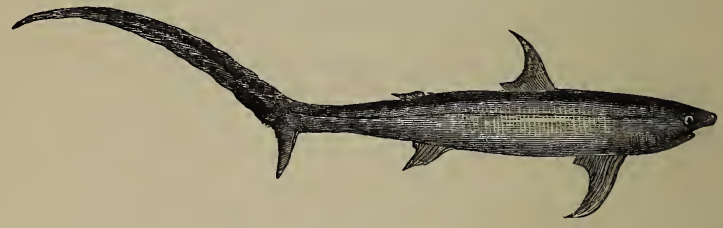

FOX-SHARK.

suring 8ft. 6in., which was caught off Margate in a mackerel net. The stomach did not contain anything,

About the middle of October, 1867, there were a great many sharks off our coast, and it is strange we did not find that any of them attacked bathers. In a few days I had records of no less than seven sharks appearing on the English coast, between the Isle of Wight and the North Foreland. I have a fine cast of the Beaumaris shark in my museum.

The Sea-Fox, or Thresher (Carcharias vulpes, Squalus vulpes, Squale renard), is frequently caught on the British coast: it is called Sea-fox from the form of the tail, which is very remarkable, the lower lobe being very small, and the upper exceedingly long, curving upwards, and resembling the blade of a scythe. 
In Land and Water, vol. iii., p. 608, No. 76, July 6, 1869, I record a fine specimen captured by the crew of a Yarmouth mackerel-boat: it was $14 \mathrm{ft}$. 5in. long, 5ft. 9in. in circumference, and weighed 500lbs. In October, 1867, I received a very fine thresher from Mr. Ledger; it had been caught about eight miles off Folkestone in some mackerel-nets, in which he had completely wound himself like a caterpillar in his chrysalis. He was too large to be taken into the boat, so the fishermen fastened a rope round his tail and towed him, stern foremost, into the harbour, whence he was sent up to me.

As we came out of the railway station I stopped the van at the weighing-machine, and ascertained that his weight was $3 \frac{3}{4} \mathrm{cwt}$. The total length of the body, with tail, was $13 \mathrm{ft} .6 \mathrm{in}$, the tail alone measuring $6 \mathrm{ft}$. $10 \mathrm{in}$. With the assistance of H. Lee, Esq., C. Hambro, Esq., and other friends, and by working late at night, I made a very good cast of this fish. The stomach contained no less than twenty-seven mackerel, some freshly caught, others partly digested. The liver was in two lobes and very large. The stomach, I found, when held out, would contain about a bucket and a half of water. The inner surface was covered with longitudinal ruga of uniform diameter. The lower end of the stomach ended in apparently a second stomach; but upon opening this a most peculiar structure was visible. The small intestines, instead of being prolonged to a considerable length (as in the sheep, \&c.) is coiled round upon itself, as in a corkscrew. Paley, in his chapter upon Mechanical Contrivances in the Structure of Animals, writes of this as follows:- "In the fox-shark the intestine is apparently straight from one end to the other; but in this straight and consequently short intestine is a winding, corkscrew, spiral 
passage, through which the food-not without several circumvolutions, and, in fact, by a long route-is conducted to its exit. Here the shortness of the gut is compensated by the obliquity of the perforation." This structure can be seen in any of the common dog-fishes or skates.

In his Bridgwater Treatise my father applies this fact to the elucidation of the intestinal structure of the monster Ichthyosauri and Plesiosauri, which formerly existed in large numbers in the British seas, and whose skeletons are so frequently found fossilHis argument was that, according to the structure of the teeth of an animal, so would be the structure of the stomach; and when he found that the coprolites were marked externally with spiral grooves, he concluded that the structure of the intestines of the Ichthyosauri were spiral in form, as is the case with modern sharks. He even found out what fish these ancient "sea dragons" had been eating, inasmuch as scales of a fish called the Dapedium politum were found in the coprolites. In the same way, if my foxshark had become fossil, remains of mackerel might have been found, giving evidence of what this creature had eaten.

The Fox-shark is, I believe, more an Arctic animal than the Beaumaris, porbeagle, or blue sharks, the kinds generally found in the British seas. From the small size of the teeth of the fox-shark, I conclude that it is more formidable to small fish than to the larger inhabitants of the sea. No one has yet been able to ascertain why the tail is so remarkably prolonged. It is sometimes called the "thresher shark," because it is said to inflict chastisement on the whale, though I can find no real authority for this being the case; nor can I see why the shark should flog the whale. The tail of the skate can, as I know to my cost, inflict severe wounds, and the tail of the sting-ray contains a dagger which is even more formidable still; I fancy, therefore, that the tail of the fox-shark is used by the owner as a weapon of defence, for if he chooses to use it, it would act like a 
waggoner's whip. Again ; I think it just possible that, whereas we all know we can drive fish by long poles dashed suddenly into and about in the water, so the fox-shark may use his tail to splash about and drive the frightened herrings or mackerel into the position where they will be most handy for him to catch and swallow. I should imagine an un-frightened mackerel to be a difficult thing to catch when swimming at liberty in the sea. If, however, the fox-shark comes lashing about with his tail, he and his comrades would become confused, and while making up their minds what to do and where to go, they would suddenly find themselves going down the shark's throat. One thing is quite certain, his long tail would enable him to turn smartly round the corners and astonish unsuspecting natives.

In August I received a very handsome specimen of a thresher from Mr. Henry Lee. It was caught off Hastings. I imagine it to be about two years old. I made a cast and placed it alongside of the big thresher. It measured $2 \mathrm{ft}$. $4 \mathrm{in}$. from nose to end of body, the tail $2 \mathrm{ft} .9 \mathrm{in}$.; total length $5 \mathrm{ft}$. 1 in.

In October, 1869, I had information from Mr. Ledger, of Folkestone, that a very fine fox-shark had been sent up to London. Messrs. Gilson and Quelch, of Bond Street, sent to me and kindly informed me of the arrival of this same fish. I immediately examined it, and found it to measure 14ft. 10in. total length. It had been caught in the herring nets. The viscera was sent me by Messrs. Gilson and Quelch, and the stomach contained nineteen mackerel and two herrings. I made a cast of the ovaries, in the oviduct of which I was fortunate enough to discover an egg on its downward journey. It is similar to the egg of the dog-fish: an amber-coloured bag, and much like the shelless egg 
sometimes laid by common fowls, about $3 \mathrm{in}$. long by $2 \frac{1}{2}$ in. wide. At the top of the oviduct $I$ found a mass of ova united together in a sponge-like material; they varied in size from a hazel nut to the size of the head of a pin, and lay close together; each was perfect in itself, and contained yellow albuminous fluid. There must have been many thousands. This one fact shows how little we know of the habits of sea-fish. I should certainly have expected to find the egg of a $15 \mathrm{ft}$. shark more than 3in. long: the egg, probably, from the appearance of the specimen, was in a growing and undeveloped state.

I have taken down, in his own words, the following evidence as to the fights between the threshers and the whales in the northern seas, given by Mr. Hill, captain of the North Sea trawler Hurricane.

"The thresher sharks just do serve out the whales. The sea sometimes is all blood. A whale once got under our vessel (the Hurricane) to get away from these threshers, and when she was there we were afraid to throw a rope overboard, almost to walk about, for fear she should chuck her tail, and punch a hole in our vessel. She was full length in water as clear as gin, right under our bottom, and laid as quiet as a lamb for an hour and a half, and never moved a fin. Whiere they had been a-thrashing of her the sea was just like blood. I have seen these ere threshers fly out of the water as high as the mast-head and down upon the whale, while the sword-fish was a-pricking of un up from underneath. There is always two of 'em, one up and one under; and I think they hunts together; and you can see the poor whale blow up in great agitation; and I be bound the pair on 'em don't leave him until they have their penn'orth out of him. It's just for 
wengeance they does it. Whether Master Whale has offended them or not, it's hard to tell. If they eats him they must have a tidy blow out off of him, but I don't think they like the oil. I saw one engagement off the Staples; it was all two or three hours they was at it. I don't think they leave him till they kill him."

This story was told me in all good faith, but it will not, I think, bear cross-examination. Both species of sword-fish-both the fellow that charges ships, the Histiopherus, and the flat beaken sword-fish-do not live in the cold water of the Arctic Seas. They are both inhabitants of warm tropical or semi-tropical seas. Nor, again, can I understand why the thresher-sharks should attack the whale. All this requires investigation, but I fancy I have been able to explain the story. (See Appendix, p. 384.)

The Hammer-headed Shark (Squalus zygana, Zygana malleus, Squale marteau; French: Marteau commun)

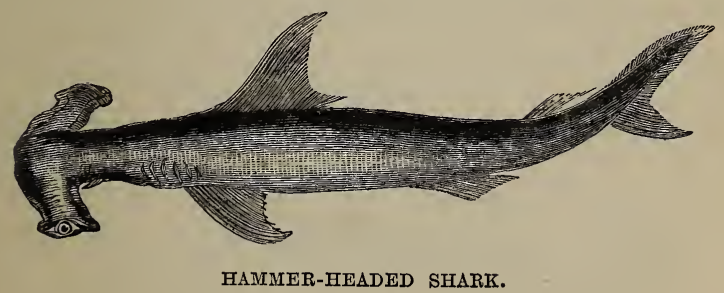

is a very rare British fish. The singular form of the head, from which this genus obtains its name, at once distinguishes it most unmistakably from all other fishes. The head is truncated, and the sides extended horizontally into a kind of branch, the eyes being placed at each extremity; they thus look as if they were planted on two thick peduncles. The head of the shark, as 
represented below, shows the position of the mouth. The eyes are furnished with eyelids; the iris is golden yellow; the nostrils are placed close behind the notch over each eye.

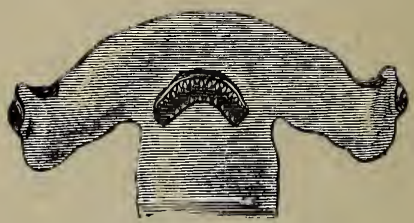

HEAD OF HAMMER SHARK.

\section{THE SILLOCK, OR COAL FISH.}

(Merlangus carbonarius.)

German : Der Köhler. Danish : Sej. Norwegian: Smaapale. French :

Le Charbonnier. Swedish: Grasida Sej.

The Sillock, or Coal Fish, so called from the black colour it sometimes "partially assumes, is decidedly a northern fish, and abounds in all the northern seas, and in the Baltic; it swarms in the Orkneys, where the young are, during the summer and autumn months, the great support of the poor. It is a fish

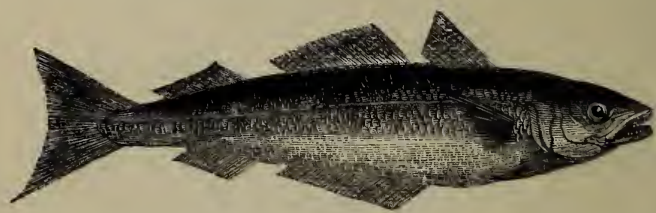

COAL FISH (Merlangus carbonarius).

of rather handsome form and small, tapering head; the general outline and forked tail reminding one of the elegant proportions of the salmon. Not only does 
it yield a wholesome and substantial food, but also isinglass; and as it is a very sharp biter, and swims at no great depth, it is readily taken with the line. The coal fish is called in Scotland the sillock, pitlock, harbin, sethe, and grey lord; in Edinburgh they are called "podleys;" in Ireland they are called glosong or glassan; in the Galway markets they are known as "black nuns." They run to a large size, and frequent deep water. They are great enemies to all fish, especially to the herring-fry, and do immense mischief to the salmon smolt. The late Mr. Ffennell, Inspector of Salmon Fisheries, saw twenty-six salmon fry taken from the stomach of one black sillock.

\section{SKATES, OR RAYS.}

We have some four or five British genera, including in all about fifteen species. Of these the famed Torpedo is one. The Common Torpedo, or Electric Ray, has been known as existing in the English seas.

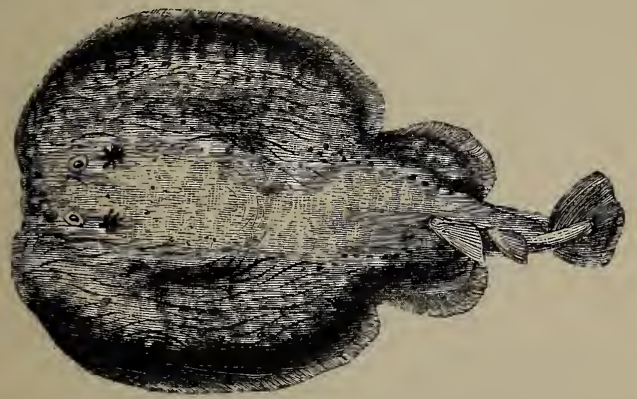

TORPEDO, CRAMP RAY, TURPAENA, NUMBFISH, ELFCTRIC RAY.

On the 3rd of October, 1868, when at Falmouth, I received a telegram from Mr. Matthias Dunn, of Meva- 
gissey, Cornwall, stating that he had in his possession a torpedo, which had just been caught. On my road home I picked up (at the station of Mevagissey) the box containing the fish, and brought it up to London. The general shape of the torpedo is that of a ray or skate; it has no spines whatever about it, and the skin is soft and flabby to the touch, very like wetted wash-leather. The general colour is a dark chocolate. The specimen weighed $35 \mathrm{lbs}$., and measured at its broadest part $2 \mathrm{ft}$. $7 \mathrm{in}$, and from end of tail to tip of nose 3ft. 9in. The first thing observable on laying the fish on the table were a number of peculiar lines upon the back. These radiate from a central line and distribute themselves all over the body. I suppose these are nerves, forming the outpost sentries on guard over the great electric fortress of this marvellous fish. Round the anterior portion of the body could be seen and felt under the skin a number of round, hard nerves, bound loosely together by a membrane, and in section not unlike a submarine telegraph wire. I have no idea what is the function of these; of course they have their duty, but no investigators seem to have noticed them. On each side of the eyes of the fish, as it lay on the table, could be seen a deep depression, occupying the major part of the anterior part of the body. I dissected off the skin on one side and exposed to view the wonderful electric apparatus. This consists of a mass of soft structure, reminding us somewhat of " size." It was covered with a dense fascia-like membrane, and on dissecting it off can be seen a series of white pliant columns, in a close and, for the most part, hexagonal arrangement, like an unbroken honeycomb just removed from the hive; or, if we wish for another comparison, like a street pavement made of pillars of basalt, as oftcn 
seen in German towns. John Hunter, who published an exhaustive paper on the anatomy of the torpedo, in "Philosophical Transactions for 1773," gives the number of these columns to be about 470 in each conglomerate mass - the longest column being about $1 \frac{1}{2}$ in., the shortest about the fourth of an inch, and in diameter about two-tenths of an inch. The ultimate structure of these columns can be seen in the wax models of the structure of the torpedo at the Royal College of Surgeons; these magnificent demonstrations of structure were made by Professor Calamai of Florence, and presented by His Imperial and Royal Highness the Grand Duke of Tuscany to Professor Owen, and by him to the Royal College of Surgeons, January, 1850.

If we can imagine one of the series of the cells broken off and held up to the light, we should have the appearance of a single cell of a honeycomb-the wax walls being represented by a gelatinous membrane, thinner than goldbeater's skin; inside the cell may be seen, not honey, but a jelly-like transparent fluid. We shall also see that a membrane, thinner still than that which composes the walls, divides the contents of the cell into a series of chambers. Upon these transverse septa, or partitions, the microscope would show the most marvellous ramifications of the blood-carrying capillaries; and the ultimate meshes of the great electric nerves will be found to have spun themselves, as it were, into a network, with complicated meshes, far exceeding any cobweb in tenuity and minuteness. The interval between the transverse plates, Professor Wyman states, is occupied by a fluid, consisting of about ninety per cent. of water, containing albumen and common salt.

Next will be observed four enormous cord-like nerves; 
these, as they pass into the skull, are carefully bridged over with bone, to prevent any undue pressure upon them from above; running under these bone bridges we find them directly connected with the brain: they start directly from the brain and begin their course at once, just as do the electric wires from a telegraph office through a hole bored in the wall of a house. The brain itself is absurdly small, and is lodged in a cavity apparently much too large for it.

In order to preserve the parts in their proper position, I made a cast of the torpedo, with its electric battery, the moment I had finished the dissection. I also made a cast of the fish before it was dissected. These casts are at my museum, and will, I think, give the visitor a good idea of the general appearance, as well as the outward structure of this very wonderful fish. I cannot determine in my own mind the exact. economy and mode of action of the complicated electrical machinery of the torpedo. Does the brain create the electricity and transmit it to the cells for storageas in a Leyden jar-or do the cells both secrete the electricity and store it? If this latter be the case, why do we find such large nerves going to the brain? This may appear at first sight a trivial point, but the human brain and nervous system being the most complicated of all mammalia, we are tempted to reason as to the mode of their operations, by comparing them with the same machinery of nerves and brain as found developed in lower forms of animal life. I do not know of any mammal which has the power of secreting electricity. This power is confined to this class of fish alone. These fish are enabled to emit a certain number of shocks only; they then require rest for the accumulation of more electricity. 
My own idea is that the electric power is given to the fish to kill its prey. I can see no other way that the poor thing has to procure its living. The teeth of the torpedo are exceedingly small, and certainly not suited to the capture of any vigorous or lively prey ; the appearance of the fish is that of a skulking rascal; his coat is almost mud colour. He is probably too lazy to hunt after his own food, and doubtless remains half asleep in the mud till something worth eating walks upon him or swims over him, he then "lets fly," and gets his dinner without much difficulty.

Finally, it is a most interesting and curious thought, that the marvellous fluid electricity, which we human beings call into existence by means of complicated arrangements of acids and metals, should be generated by an animal structure composed of the most delicate nerve fibres and tissue; this arrangement, moreover, being found in the back of a fish which lives in the depths of the sea. We pride ourselves much upon our telegraph across the bottom of the Atlantic, little thinking that living and moving electric batteries have been in existence for hundreds of years before electricity was ever discovered, much less applied to purposes of social economy.

The structure of the torpedo is an answer to those who dispute the wisdom and design exhibited in created things. How is it possible that any number of years, or any other causes, could have produced an electrical apparatus so exceedingly perfect and so complicated in itself that, although man may investigate its ultimate structure, yet he is perfectly ignorant of its operations? No! the same great Power that orders the lightning to shine from east to west in the wide heavens, or the aurora borealis to illuminate the sky of the ice-bound 
regions of the Arctic circle, has thought fit to apply this same mysterious agency to the use and benefit of a humble fish. The lesson we should learn from the torpedo is that we men, with all our boasted intellect, stand but on the shores of an ocean of knowledge, the profound depths of which human understanding in its present condition will never be able to fathom.

In Land and Water, vol. vii., p. 26, Jan. 9, 1869, Mr. Jeremiah Wilson, of Stockton-on-Tees, writes : "I have taken two torpedoes in the estuary of the Tees. You say the one you dissected had nothing in its stomach. I was curious enough to see what those that I caught were living upon; so I put my knife into one, and took from him an eel 2lbs. in weight, and a flounder nearly a pound. The next one I opened also, and was astonished to find in him a salmon between $4 \mathrm{lb}$. and $5 \mathrm{lb}$. weight; and what I was more astonished at was that none of the fish had a blemish of any description, showing that your idea of the fish killing his prey with his electrical force is quite correct."

The genus Raia, or Skate, is of great extent, and includes many well-known fishes. The form of the body is flat and broad, and of a rhomboidal shape. The skate may almost be said to have no true head or neck, the sides of both being surrounded, and thus protected, by the wide-spreading margin of the pectoral fins. Their mode of progression is very peculiar, being performed with a quick flapping motion of the pectoral fins, something between a glide and a swim. Skates are very voracious: their food consists of any fish they can catch, with molluses and crustacea. So powerful are their muscles and jaws that they are able to crush the strong shell of a crab with ease. The young are produced towards the end of spring, or during summer. 
In April, 1869, Mr. Thomas forwarded to me two specimens of eggs of the skate. There were altogether twelve of these eggs; two only were fully developed. They were enclosed in a membrane. The eggs which were not developed had no coats on them, but resembled the yolk of hens' eggs. The parent fish weighed about 30lbs., and is described as a "Bashaw skate." (Query: why Bashaw ?) It had no thorns on its back, but on its wings only. It was probably Raia oxyrhynchus. Each egg is of an oblong shape, and may be likened to a handbarrow, for from each corner there projects two horn-like processes. The total length, not including the horns, is eight inches; breadth, three inches. The shell of the egg consists of a horn-like substance, feeling to the touch like a sheet of moistened leather. This horny substance is called keitene. It is analogous to the substance which forms the horny wings of beetles. The two ends of the egg differ in appearance: one end is permanently soldered up; at the other the two sheets of horn-like material are so arranged that when the young fish inside is about to be born they will give way and allow the young fish to struggle out. One of the eggs, at the end where the young one's hall door is situated, presents a feature not observable in the other-a string or rope is attached to each side of the egg just above the origin of the horns. This rope is made in the form of a string composed of the same material as the shell. After running the length of about five inches, these strings join and form an entangled mass like a small bunch of tow. There can be no doubt but that the fish anchors her egg, and these ropes act as "guy ropes" to keep it steady when floating in the water.

On opening one of these eggs, and turning away one side like a trap-door, I find the contents consist of a mass 
of pure albumen, wrapped up in a most delicate membrane; this would eventually have become the young fish. It is comparatively rare to find one of these eggs with young fish alive in them, although they are occasionally thrown up after severe storms. The moment the young fish is hatched the empty shells float away, and visitors at the sea-side are perfectly familiar with them, as they are thrown up on the shore by the waves. These are generally black : brown ones are very scarce. They are known by the name of "Shepherd's Purses," or "Skate hand-barrows."

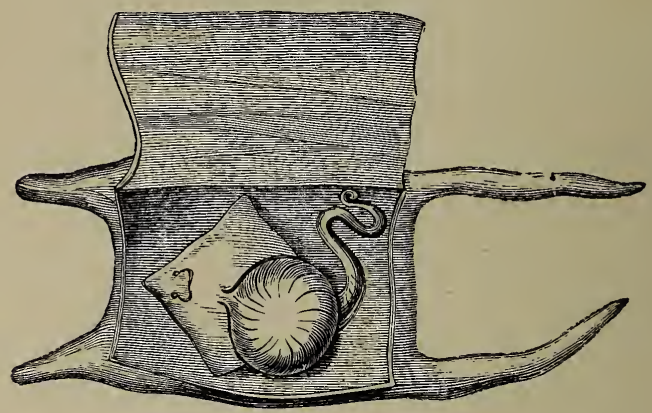

EGG OF SKATE, SHOWING YOUNG.

In May, 1872, I received two very large skate eggs from Mr. Matthias Dunn, of Mevagissey ; they measured 16in. in length, and $5 \frac{1}{2} \mathrm{in}$. in width. They were taken from a monster piper-skate (Raia lintea). Strange to say they contained no young; the young must lave been born when they were still in utero. This is very curious.

There are nine or ten species of true Rays found on our coasts, and they have been arranged in two divisions: those having the snout more or less sharp, 
and those with blunt noses; the latter are furnished with numerous sharp spines on various parts of the body.

The Blue Skate, Flair-Tinker, Grey Skate (Raia batis; German: Der Glattrochen; Danish: Rokke; Dutch : De Vleet; French: Rae Batis), or, as it is frequently called, the Skate--to distinguish it from the Thornback and Homelyn-is not uncommon. The ordinary size is from two to four feet. The nose is sharp, lengthened, and conical, the colour of the surface greyish brown, and

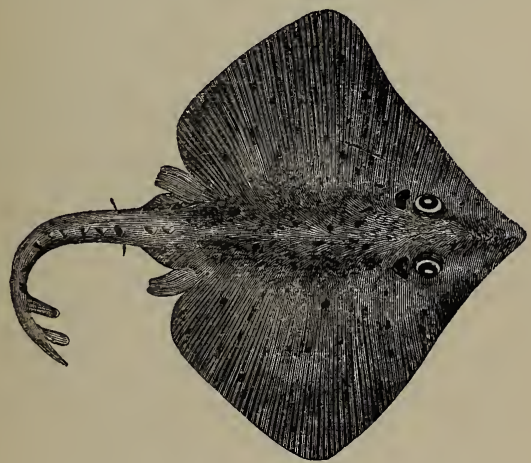

BLUE, OR GREY SKATE (Raia vulgaris, Raia batis).

beneath, greyish white with black specks; the whole surface is more or less granulated. The females are larger and more numerous than the males, and the latter have several rows of sharp hooked spines towards the sides of the pectoral fins. They are very voracious, feeding on other fish and crustacea.

In November; 1866, I received a monster skate that had been caught at Southwold, on the coast of Suffolk. When laid on the slate it looked like a big mourning hatchment, with a tail to it. It measured from nose to 
tail 6ft. 10in., across the wings 5ft. 3in.; its weight was found to be 90lbs. If the intestines had not been removed, it would have weighed over a hundredweight. With greatest difficulty I made a cast of this monster fish; the fish itself is now in the British Museum, and the cast at my fish museum. I believe blue skates even larger than this have been sometimes caught.

The Long-nosed Skate, or Shagreen Ray (Raia mucronata, Raia oxyrhynchus; German: Dee Spitznase), is distinguished by the great length of the nose, which is narrow and sharp. The upper part of the body is of a cinerous brown, covered closely with minute shagreenlike tubercles resembling the skin of the dog-fish. The under side is white, and the teeth are slender and sharp as needles. It grows to a considerable size, and is said to feed on sand-eels and the sand-launce. It frequents deep water, and is not caught in the winter.

The Sharp-nosed Ray has the snout sharp, slender, and very much elongated. It may be recognised by this, and by the waved line of the margin of the body, from the nose to the centre, and by its pure white colour underneath. It is the largest of the British rays, and is also thicker in proportion than the others; the tail is armed with three rows of spines. This skate is known by various names in different places, such as White Skate, Burton and May Skate. It has been taken on many parts of the coast, and in some places is by no means rare.

The Bordered Ray (Raia marginata) is so called on account of having a broad dusky border on the under side, the other parts of the surface being white. The skin is smooth, and the snout sharp, slender, and moderately long: a few specimens only have been taken in Engiand. 
The Flapper Skate (Raia intermedia) is another sharpnosed species, which seems to be a connecting link between the sharp-nosed and the blue skate.

Of the Blunt-nosed Rays, the Homelyn and the Thornback are the two species most common in the London market. They are not very dissimilar in shape, though distinct. The former is called the Sand Ray and Spotted Ray. It is subject to great variety in colour and marking - sometimes the upper surface is numerously spotted, at other times sparingly so, or not at all; and occasionally it has only one eye-spot on

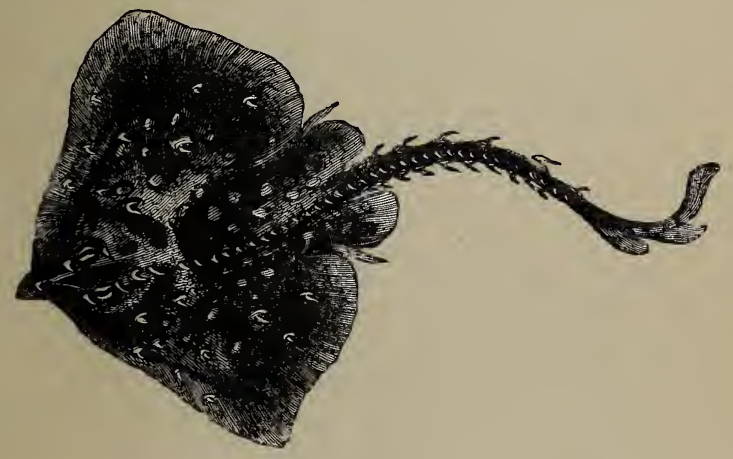

THORNBACK.

each side. These varieties have given rise to different names. The nose is short and rather obtuse ; the teeth, in the adult fish, are sharp-pointed, the skin smooth, and generally there are three rows of spines on the back. It is from two to three feet long. The colour is brown or reddish brown, marked with distinct roundish dusky spots. This fish is most frequent along the southern coast.

The Thornback (German: Der gemeine Dornrocken; 
Dutch : Rog; French: Raie bouclée) is dispersed throughout the British seas, and almost everywhere caught in numbers. There is no difficulty in distinguishing it, as it is known at once by being studded at intervals all over the surface with rounded nail-like tubercles, which terminate in strong curved spines. The tail is armed with several rows of spines, and a single row runs up the dorsal ridge. The prevailing colour is brown, with numerous lighter spots; the colour beneath is pure white, with a few spines only.

The Small-eyed, or Painted Ray (Raia microcellata), and the Starry Ray are both very rare and little known.

The Sting Ray, Fire Flare, or Fiery Flaw (German: Der Stechrochen; Danish : Pilrolike), is frequent on the

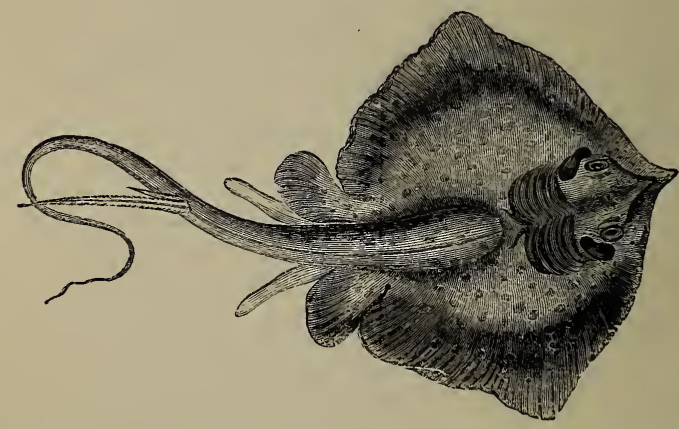

STING RAY (Raia pastinaca, Trygon pastinaca).

southern coasts, from Sussex as far west as the county of Cork in Ireland. The manner in which it defends itself is by twisting its long, slender, and flexible tail round the object of attack, and tearing the surface with the serrated spine, lacerating it in a manner calculated to produce violent inflammation. I have dissected and 
cast two specimens of this fish caught at Herne Bay. The spines on the tail are very formidable weapons indeed, and inflict severe wounds. The fishermen generally chop his tail off with an axe directly he is out of the water.

The Eagle, or Whip Ray (German : Der Meeradler; French: Fiaie Aigle), is also called the Miller, on

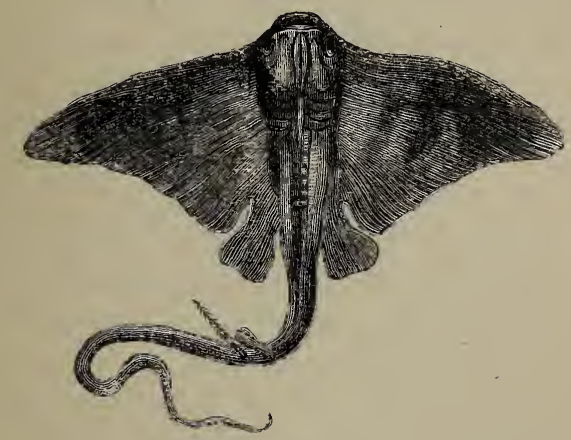

EAGLE RAY (Hyliobatis aquila, Raia aquila).

account of the form of its teeth. Each jaw forms part of a circle, and from a particular rolling motion, added to the crushing power of these teeth, the genus has obtained the name of Myliobatis, i.e., Mill Skate. It is extensively distributed, and attains a large size, sometimes measuring fifteen feet in length, and weighing $3001 \mathrm{bs}$. "It swims pretty rapidly, with a kind of sailing motion, and little action of the pectoral fins, and when taken vibrates its tail violently; the first care of the fishermen is, therefore, to cut off the caudal spine, which in a large specimen is a very formidable implement."

In November, 1871, Mr. Frank Gorden, fishmonger, of Exeter, obtained a specimen from Brixham. The 
colour was a magnificent bronze green, and it measured from the eyes to the tip of the tail three feet ten inches, the tail measuring two feet four inches. The tail resembled a rat's, and was about the same thickness, and when dry resembled one of those penny gutta-percha whips sold in the London streets. This specimen is now in the Exeter Museum.

In December, 1867, my friend $H$. Lee obtained an egg of the eagle ray from Margate. He writes :-

"When first brought to me, wet from the sea, the purse or sac which had contained the embryo measured eight inches in length by five inches in width, and the length of the long tendrils, which are flat and thin, was 10in." The eggs of the eagle ray differ much from those of the skate, which, under the name of "Devil's purses," are known amongst the common objects of the sea-shore. Mr. Couch describes its surface as being " curious and beautiful, thickly set with raised longitudinal lines, closely crossed with dots or raised lines, each longitudinal line being thickly studded with raised markings, points, or short lines, which, however, do not pass from one line to another, although they appear to sink into the minute channel between them." This description, however, only applies to the middle of the case; for towards the ends and sides the longitudinal lines are joined in this manner, and the reticulations form beautiful squares, which grow finer towards the border, and disappear at the margin. Colour, approaching to black.

Of the Horned Ray or Manta Fish, a single specimen was found in 1835 on the southern coast of Ireland. This species belongs to a genus (Cephaloptera) which differs most couspicuously from the other spiny-tailed rays in the form of the head, which is cut short in 
front; while the pectoral fins, instead of surrounding it, are each prolonged considerably in front, so as to present the appearance of two horns. The species are also very remarkable for the enormous size they sometimes attain.

"R. D. P." in Land and Water thus writes: "Its name is derived from the Spanish word manta, signifying mantle, indicating at once its shape and the facility it has of enclosing its prey within its folds. They sometimes frequent the pearl oyster banks, and are much dreaded by the divers.

\section{THE SPRAT.}

Abdominales Malacopterygii.

Clupeida.

(Cluper sprattus.)

German:Die Sprotte, Der Breitling. Dutch: Sprot. Swedish: Skarpsill. Danish : Brisling. French: Menuise, Le Melet, Esprot, Harenguet, La Sardine. Scotch: Garvie, Herring.

THIs fish comes into the market during the winter months, and generally appears in London on Lord Mayor's Day (November 9th).

Sprats are taken on many parts of the coast both by the seine and drift net; but, like the rest of the genus, they are wanderers; the shoals are capricious in their movements, and exceedingly variable in their numbers, as well as in the time of their appearance. The chief fisheries for sprats are the large estuaries in the North Sea, fronting especially the Firth of Tay, Firth of Forth, Beauty Forth, and the Moray Forth, and the estuary of the Thames. The fishing season continues through the winter months, and the largest catches are taken when the nights are dark and foggy. Not unfrequently they are so abundant as to be used for manure, and 
many thousand tons are annually disposed of in this manner.* The length of the sprat is from $5 \mathrm{in}$. to $6 \mathrm{in}$.

Its food is similar to that of the herring. In my "Curiosities of Natural History" I have thus described the sprat's mouth: "It looks a little tiny mouth, not large enough to admit a pin's head; but just push down the lower jaw, and what do you see? Why, one of the most beautiful insect nets it is possible to conceive. A net into which you can get the top of your little finger, and of necessity terribly destructive among the minute sea creatures which the sprat feeds on-those pretty little animals which cause the sea to be luminous at night, forming, doubtless, part of the bill of fare."

As the salmon has parasites on his scales, the Lerneonema, and in his gills, so we find that the sprat has a parasite called Lernaa spratti.

These parasites fix themselves on to the eye of the fish and there anchor themselves, a portion of the body, and the ovaries, which are like two long green threads, hanging loose to the length of $2 \frac{1}{4}$ in. They sometimes enter the body of the fish near the dorsal fin, and pierce to the depth of $\frac{1}{2}$ in., the head coming down from the back of the sprat, through the flesh, nearly to the belly. They are of a beautiful green colour. The fishermen call them "Lantern Jacks." The story is that the fish which carries these "Lantern Jacks" is the pilot fish of the shoal, and that the lantern is luminous at night, and the shoal steers itself on the course indicated by the bearer of the "Lantern Jack."

There is confusion in the minds of those concerned as regards names. Some designate a sprat a "garvie;" some call a young herring a "garvie;" some call both sprats and herrings alike "garvies."

* See "Deep Sea Fisheries Report, 1879." 
Having investigated, both by dissection and otherwise, this moot point, I have come to the conclusion that the sprat is a distinct species of fish. The following are the chief points by means of which it may be distinguished from a young herring :-

1st. The shape is different from that of the young herring, the depth of the body being greater in proportion to its length than in the case of the young herring.

2 nd. The belly of the sprat is serrated or edged with sharp spines; the belly of the herring is carinated.

3rd. The formula of the fins is different.

4th. The dorsal fin in the sprat is placed further back than in the herring. If the sprat be cut in two with a sharp knife, drawn directly in front of the dorsal fin and vertically to the belly, the section will cut through a portion of the ventral fins on the belly; whereas, if a young herring be cut through in the same manner, the section will pass in front of the ventral fins.

5th. In the ventral fins of the sprat there are no axillary rays, whereas these are found in the herring.

6th. The operculum, or gill cover, the bone immediately behind the eye, is narrower in the sprat than in the herring, running up in the former nearly to a point near the eye.

7th. If a young herring be held up to the light, the tail having been moistened, and the rays drawn together with the finger and thumb, it will be observed that a black line will appear in the middle of the fin, whereas in the sprat no such line will be visible.

8th. In the herring the lower jaw is prominent, so that when the mouth is closed a slight projection of the snout will be observed; in the sprat the jaw runs smoothly off ; to use the fishermen's term, the sprat is "snugger in the nose" than the herring. 
9th. In the sprat the teeth in the lower jaw are so small as to be hardly apparent to the touch, whereas in the young herring the teeth are easily distinguished.

10th. In the herring there are 56 vertebræ, in the sprat 48.

The foregoing are the structural differences between the sprat and the herring. Besides this, the difference may be readily distinguished by the senses of smell and taste.

Thus there are three senses by which the sprat may be diagnosed from a young herring, viz., touch, smell, and taste.

1st, Touch.-As already stated, if the belly of a sprat be gently tested by the finger, the direction of the movement being from the tail towards the head, it will be found that the forward progress of the finger is arrested by spines projecting from the belly. These spines are so sharp that if the test be made with the tongue they will lacerate it. If this row of spines be cut off and dried, it will be perceived that they are 29 in number. Commencing under the gills thoy are short and overlap each other. They become more prominent towards the ventral fin, and are largest immediately behind that fin. If the row of spines just cut off be gently boiled, it will be perceived that this armature of spines is formed of separate plates, each spine being fixed in the centre of a thin plate of bone; these plates may be said to resemble flics with their wings open, the head of the fly boing represented by a sharp needle-like point.

2nd, Smell.-The sense of smell is one of the most serviceable of all the senses to a human being; particularly is it useful as regards matters of food. When a sprat is placed on the fire, the smell of the flesh of the sprat burning is much more savoury and appetising 
than that of the herring, and can be discerned at a much longer distance. This is on account of there being naturally so much more oil in the sprat than in the herring.

3rd, TASTE. - The taste of the sprat is quite distinct from that of the herring.

Acanthopteri.

\section{STICKLEBACK.}

Sclerogenida.

\section{(Gasterosteus trachurus.)}

Local names: Banestickle, Bannis Bannistickle, Banstickle, Barce, Barmy, Banticle, Bonetickle, Hackle, Harry-banning, Jack Sharpling, Jack Sharpnails, Minnis Prickleback, Prickle-fish Pricky, Pricky-back, Rough-tailed three-spined Stickleback, Rough-tailed Stickleback, Shaftling, Sharpling, Stand, Stanstickle, Stekelynge, Stickling, Styckelyng, Tanticle, Threespined Stickleback, Tittle-bat, Tommy-parsy Titler, Tinker. German: Der Stickling, Stickelstarpe. Danish: Hundstag. Swedish: Stigg Benbuk. Dutch: Stekelbaars. French: L'Espinoche. Italian: Spinarello.

MANY anglers will confess that they were first "entered" to the noble sport by fishing for Sticklebacks, which abound in all the ponds and ditches in the neighbourhood of London. These fish are also very common in canals, especially in the Regent's Park Canal. In the summer time, thousands of little boys go out fishing for " tittlers," their apparatus consisting of a stick, a piece of thread, and a short piece of worm tied in the middle without any hook; if expert, they sometimes pull out two at a time in this way. The fashion is to take them home in pickle-bottles; and the boys generally sell them, sometimes getting as much as sixpence a bottleful. I always encourage these boys, as the little urchins are thus taken out of the London streets, and have a chance of learning 
a little natural history. There are many species of sticklebacks.

The Three-spined, or Rough-tailed Stickleback (Gasterosteus spinulosus), is one of the largest and most powerful of the family; it ranges in size from 2in. to 3in.

The stickleback is to be specially admired among fishes, as being a nest-builder; and I would advise my readers to get some sticklebacks, and themselves observe the process of nidification. They spawn in warm

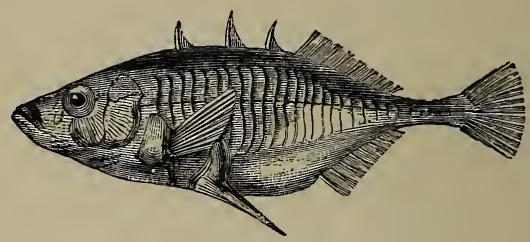

THREE-SPINED STICKLEBACK.

weather, from April to June. The following facts occurred in 1857 under the notice of the curator of the Norwich Museum :

Two glass troughs filled with aquatic plants and animals were provided, into which a solitary individual of either species was inducted. Each made himself quite at ease ; and a female companion being introduced into the domicile, he was not long in commencing the work of nidification.

The appearance of the three-spined stickleback was. exceedingly beautiful. The little creature's throat and belly were of a bright red colour, and his eyes of a brilliant bluish-green, having a perfectly metallic lustre, not unlike the green feathers of a humming-bird; and the whole fish seemed somewhat translucent, and glowing with an internal brightness.

He selected a spot nearly in the centre of the trough, 
and busily set to work to make a collection of delicate fibrous materials, resting on the ground, and matted into an irregular circular mass, somewhat depressed, and upwards of an inch in diameter, the top being covered with similar materials, and having in the centre a rather large hole. His work was commenced at noonday, and was completed and the eggs deposited by halfpast six in the afternoon. Nothing could exceed the attention from this time evinced by the male fish. He kept constant watch over the nest, every now and then shaking up the materials and dragging out the eggs, and then pushing them into their receptacles again and tucking them up with his snout, arranging the whole to his mind, and again and again adjusting it until he was satisfied; after which he hung or hovered over the surface of the nest, his head close to the orifice, the body inclined upwards at an angle of about $45^{\circ}$, fanning it with the pectoral fins, aided by a side motion of the tail. This curious mancurre was apparently for the purpose of ventilating the spawn; at least by this means a current of water was made to set in towards the nest, as was evident by the agitation of particles of matter attached to it. This fanning, or ventilation, was frequently repeated every day till the young were hatched; and sometimes the little fellow would dive head foremost into his nursery and bring out a mouthful of sand, which he would carry to some distance and discharge with a puff. At the end of a month the young ones were first perceived. The nest was built on the 23rd April ; the young appeared first, May 21st.

Unremitting as had been the attention of this exemplary parent up to the time of the hatching of the eggs, he now redoubled his assiduity. He never left the spot either by night or by day; and during the daytime he 
guarded it most pertinaciously, allowing nothing to approach. If any of the water-animals chanced to come near, he would instantly pounce upon them, and unceremoniously shove or tumble them over. If a stick or quill were passed down from the top of the vessel, he struck it fiercely, and with such smartness that the blow was distinctly felt by the hand.

The fry were at first so minute and transparent, that. they were scarcely perceptible, and it was only by a slight fluttering motion their position could be occasionally discovered; otherwise it was impossible to detect them. They were for a time confined to the meshes of the nest, and its near neighbourliood, but by degrees were allowed greater space; and the parent fish hollowed out a sort of small basin for them, in which they disported themselves, until they were strong enough to take a wider range.

In consequence of there being no other fish in the vessel, we did not see the battles and stratagems which are carried on between companions and rival fishes when engaged in similar parental duties. The encounters on such occasions are said to be fearful and prolonged, and it is not without reason the young nestlings are so carefully guarded, as acts of cannibalism are not unfrequent.

I strongly advise my readers to repeat for themselves the above interesting observations.

As regards the nestling of sticklebacks, my late lamented friend $\mathrm{Mr}$. Smee writes, in his admirable book "My Garden " :-

"Throughout the Wandle there are plenty of sticklebacks of the species called by the learned the half-armed stickleback, or Gasterosteus semiarmitus. They are very pugnacious and amusing creatures. They build a nest, 
and protect it. In the middle of May I observed a stickleback evidently guarding a circle of about 2 in. in diameter, and chasing away every other fish which came within his domain. On closer examination, I saw at the bottom of the water a small circular place about 2 in. in diameter made of fibre, but arranged level with the bottom of the stream. Suspecting a nest, I carefully raised this material, when it proved to contain two parcels of eggs, which were about the size of a large pin's head. I immediately replaced the material as well as I could in its former place, but Mr. Stickleback was not at all satisfied with my arrangement, and set to work diligently to adjust it himself. He brought little bits of fibre and thrust them into the mass, and re-arranged the larger fibres. One parcel of eggs protruded; these he dragged away and began to devour; but I took possession of this mass and placed them in a jar with water-plants, where they soon after hatched into beautiful little fish. However, the stickleback continued his work at the nest: sometimes he would bring a piece of fibre in his mouth, and with violence thrust it into the mass ; then at other times he would drag his body with all his strength over the mass to smooth it down. When he was perfectly satisfied with what he had done, he mounted guard and rushed at any other fish which came near him.

"Afterward, I found these nests by scores, each protected by its guardian stickleback; and in the month of May I can always delight my visitors by showing them a nest presided over by the pugnacious little fish."

A large number of sticklebacks are caught in the deeper portions of the River Thames by men engaged in fishing for whitebait. When caught with the white- 
bait these fish are of an exceedingly beautiful colour, as bright as a new shilling, and the diner-out at clubs will discover sticklebacks on his plate if he will look for them; they are very good eating.

The Ten-spined Stickleback (Gasterosteus pungitius) is one of the smallest of the fishes that occur on our coast, as well as many of our rivers and creeks, up which they migrate in shoals in the spring. It is from an inch and a half to two inches in size, and is distinguished from all the rest by having nine or ten spines on the back, and by the sides being perfectly smooth, without any lateral plates. It can be found in almost all the marshes along the estuary of the Thames. This fish also builds a nest.

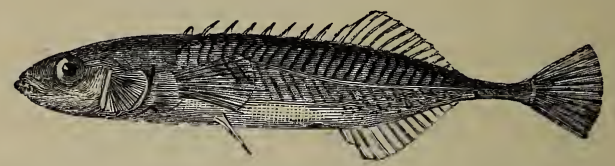

TEN-SPINED STICKLEBACK (Gasterosteus pungitius).

Sticklebacks are a very great nuisance by getting into reservoirs, when, notwithstanding the filters, they get sometimes pumped up from the mains which supply the houses.

I lately heard a story from my friend Mr. Bartlett, of a milkwoman not very far from Albany Street; she served out at the door a pennyworth of milk, and in the milk jug the servant girl found a live stickleback swimming about. When the fish, all alive oh! in the cow's milk, was shown to the old woman, she turned round to her boy and boxed his ears. "Jimmy, oh! Jimmy, you lazy rascal," she said; "you never strained the water!" 
Sticklebacks in Prussia are used for feeding ducks and pigs. I do not see why they should not be utilised in this country.

The Fifteen-spined Stickleback-Cornwall; Bismore, Orkney (Gasterosteus spinachia; German: Dornfisch) -will at once be recognised by its many spines, prolonged tail, and elongated snout, the under jaw projecting. The nest was first noticed by Mr. Couch, on the Cornish coast, 1842, and has since been observed by other naturalists. It is composed of pendant seaweeds, bound together by a silk-like thread into pearshaped masses, in the centre of which the spawn is deposited. One of these nests was visited every day for three weeks by Mr. Couch, and the old fish was invariably found guarding it. When any part of the nest was removed, the creature immediately set about repairing the damage, by drawing together the sides of the opening, so as again to conceal the eggs, which had been exposed to view. As great force was necessary to effect this, the fish would thrust its snout into the nest, as far as the eyes, and then jerk backwards, till its object was effected. While thus engaged, it would suffer itself to be taken in the hand, but repelled any attack made on the nest.

In Land and Water, No. 39, October 20, 1866, is an engraving of the nest of this stickleback, which was found on the coast of Northumberland, and was kindly forwarded to me by Mr. Robert Embleton, of Chathill. It consists of fronds of sea-weed, fastened togethe: by means of threads; how the fish managed to secrete these threads, and subsequently to bind up the weeds with them, is beyond my comprehension. The nest itself can be seen in my museum.

I am very much indebted to our friend Mr. Reid, of 
Wick, for a stickleback's nest. It was found near the celebrated Wick Harbour by his youngest daughter and himself on the Queen's birthday, 1880. Of this beautiful nest I thus wrote in Land and Water:-

"I now present to my readers a drawing of one of the most wonderful curiosities that exists in the waters of the great Ocean. Man in his boasted wisdom often produces works of art which would seem almost to be the result, to use an Homeric expression, of God-like inspiration, and yet behold now before you a work of art which far exceeds in beauty and complexity anything that ever was thought of by the human mind.

"This object is the nest of a stickleback. It has pleased the Creator to ordain that a poor, humble seafish should be the architect of this wonderful nest. These little fish have but feeble tools wherewith to execute this work, combining in itself the highest problems of Science and Art.

"Underneath or at the edge of a secluded rock, and generally at a point out of the reach of the violent wash of the tideway, the stickleback selects an overhanging branch of sea-plants which shall act as a foundation for its nest. It is not, I believe, known whether the stickleback collects or carries together (as does a bird) the materials wherewith to make its nest, or whether the stickleback simply utilises the branches of the plants which happen to be near each other. On examining the actual structure of the nest, I am inclined to think that the stickleback takes both these courses; certainly the foundation of the stronger ropes, as it were, of the scaffold which forms the outside of the nest, have been carefully selected by design on the part of the builder.

"The main body of the nest is formed of very soft weed-in fact, as soft as sponge-and, strange to say, 
as though for the sake of ornament, our little architect has placed at the point where the nest is thickest a bit of brilliant blood-red weed. Nay, more, it appears as though the builder of the nest, fearing the risk of discovery, had worked in great broad portions of brown ribbon weed, which should act, firstly, as a covering, or band, to keep the whole structure together; and, secondly, to serve the purposes of concealment. So beautifully, indeed, is this nest constructed for the concealment of the eggs, that unless the naturalist to whom the nest was sent had been previously aware what the structure meant, he might easily have been pardoned if he had not seen the eggs at all. After a careful dissection of the outer coatings of the nest, the eggs themselves came into view. These eggs are round little bodies about the size and colour of mustard seed. They are in bunches like grapes, and we try whether they are to be separated from the bunch with ease. Another marvel; the body of eggs are all sewed into a compact mass by a very thin, delicate fibre, which in the sun glistens like a cobweb or the very finest floss silk. The filaments which hold the eggs are worked. through, over, and round them, so as to form a complete network. Here there is another mystery. How is it possible that a fish can secrete or otherwise obtain a silk-like thread, and having secreted the thread, how does it manage to work up the material composing the nest and to fasten the eggs in such a position that they are safe?"

The Half-armed, Smooth-tailed, Short-spined, and the Ten-spined Sticklebacks are the remaining British species. They are very similar in appearance, and probably in habits, to their brethren. 
Ganoidei.

\section{STURGEON.}

Acipenserida.

(Acipenser sturio.)

German : Der Gemeine Stor. Norwegian : Storje. Dutch: De Steur.

French : L'Esturgeon commun. Italian: Storione.

There are two kinds of Sturgeons which make their appearance in the fishmongers' shops: the common sturgeon, Acipenser sturio ; and the broad-nosed sturgeon, Acipenser huso - the former being the most common.

Of the natural history and habits of the sturgeon really very little is known. They are wandering fish, but yet seem to frequent the mouths of nearly all big European rivers, such as the Thames, Severn, Tay, Rhine, Elbe, Seine, Garonne, Loire, \&c.

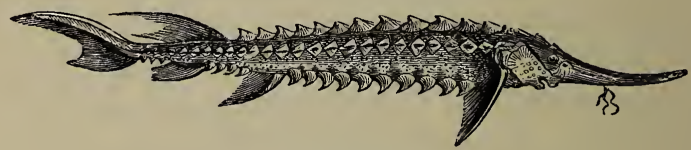

STURGEON.

These fish are of considerable commercial importance to many nations. The sturgeon is most admir. ably fitted to his mode of life, about which, however, we know little or nothing. He has a snout like the nose of a mole [that in the engraving is much too long], and he probably uses it in a similar manner as does the mole-that is, for routing up the mud at the bottom of the water and catching the worms.

Sturgeon do not require any teeth to eat worms, so he has none, but instead a most wonderful mouth, the action of which is telescopic, so that he can shut it quite close, or protrude it to a considerable length. The mechanism by means of which this is done is 
worthy the examination of those who like to see and admire the beautiful pieces of machinery as exhibited in the animal creation; in fact, in some respects, the sturgeon's mouth may be compared to the trunk of the elephant.

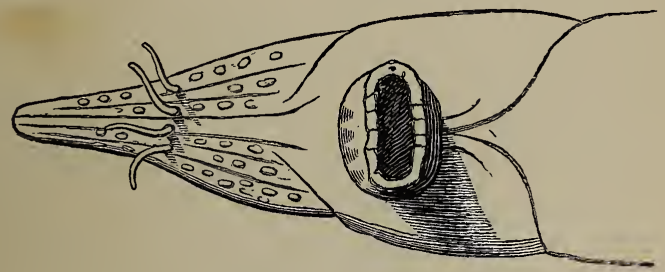

MOUTH OF STURGEON.

I have in my museum at South Kensington several good casts of both species of sturgeons, the largest being nine feet long. This was a most difficult cast to make. I have, however, in my possession the mould of the largest sturgeon, I think, ever known.

In 1879, I received a letter from my friend $\mathrm{Mr}$. H. Smethurst, jun., fish merchant, Great Grimsby, stating that his smack Kitty had just brought in a tremendously large sturgeon, caught in a deep-sea trawl net off Heligoland; a few minutes after came a letter from Mr. John Charles, fish merchant, of Grosvenor Place, Buckingham Palace Road, informing me that he had got this fish. It certainly was a most splendid specimen. He weighed $44 \frac{1}{2}$ stone, $141 \mathrm{~b}$. to the stone, which makes him no less than 5 cwt. 2 qrs. and $7 \mathrm{lbs}$. His total length was 11ft. 4in.; the head 2ft. 5in.; girth, largest part, 4ft. 9in.; his shackles or armour-plates on the back were ten in number, some as large as saucers.

Mr. Charles most kindly offered to let me cast the 
fish for my museum. I confess at first I hesitated, as the expense of casting such a huge fish would be very considerable. Mr. Charles, however, settled the difficulty by kindly offering to pay the expenses. For this act of kindness $I$ am really most obliged.

At the time this sturgeon arrived I was not well enough to attend the casting, which was done by $\mathrm{Mr}$. Searle at the stabling of Mr. Charles's ice-houses at Cheyne Walk, Chelsea, where the mould still remains, as the casting of such an immense fish requires much time and preparation, which as yet $I$ have never been able to give it. I have, however, in the museum the cast of the head of another very large broad-nosed sturgeon, a grand specimen.

When inspecting the salmon fisheries on the Wye in June, 1877, I was fortunate to arrive at the house of Mr. A. Miller, the lessee of the Duke of Beaufort's fishery at Chepstow, just at the same time that a cart arrived at the door containing a very large sturgeon that had been caught in the salmon draft net at Llandogo a few miles above Chepstow.

This noble fish measured $9 \mathrm{ft}$. $6 \mathrm{in}$. and $3 \mathrm{ft} .1 \mathrm{in}$. in girth. His weight was $3 \frac{1}{2}$ cwt.

Mr. Miller was about to deliver over this sturgeon to his Grace the Duke of Beaufort, as lord of the manor, the duke also claiming all wreckage, jetsam and flotsam. By a great piece of good luck the duke happened to come into the yard, and gave me leave to make a post mortem, at which work it is needless to say I went with a will. I found the fish was a female, containing two immense masses of caviare, or eggs. These we turned out into a basket and found that they weighed about 27lbs.

As regards the duke's claiming the sturgeon, a friend 
of mine, a distinguished lawyer, informs me that by the law of England a sturgeon is a royal fish, and should be handed over to her Majesty. By an unrepealed Act of Edward II. it is enacted that "the king shall hare the wreck of the sea throughout the realm, whales, and great sturgeon," taken in the sea or elsewhere in the realm, except in certain places privileged by the king.

The flesh of the sturgeon differs much both in colour and taste. It is said that a good cook can obtain beef or mutton, pork or poultry out of a sturgeon; in other words, fish, flesh, and fowl.

Sturgeons live a long time out of the water. I have more than once seen them quite alive, flapping about in the gutter in the street opposite the shop of my friend Mr. Davies, Gloucester; these fish having generally been caught in the salmon nets close by in the Severn. Sturgeons being so easy to transport, and being an interesting fish in an aquarium, are frequently seen in those establishments.

The first captive sturgeon that I know of was a fish presented by Mr. Charles, of Grosvenor Place, on July 26,1863 , to the Zoological Gardens. He then measured about $3 \mathrm{ft}$. He lived in the Gardens till June, 1870, seven years. When he died he weighed 14lbs. and measured $4 \mathrm{ft}$. 2in. This fish is now in my museum. I would advise my readers never to attempt to have a sturgeon stuffed. Stuffed sturgeons are hideous monstrosities.

If a record is required of the sturgeon, mark out his dimensions on a piece of board, then cut out his shape and have the board painted to life. If properly done, the sturgeons thus represented make handsome ornaments for entrance halls to country houses.

In fishmongers' shops all over the country may be 
seen the hard stud-like bones inserted into the skin of the sturgeon's back and sides. These are cut out in slips, left on the head, and allowed to dry in the shape of the fish. These preparations are known as shackles. If my readers have a chance, they should obtain a sample of these shackles, never mind how old or dry they may be. They should be soaked for three or four days in water, and then boiled till all the flesh comes off. It will be found that the stud-like bones are most beautiful objects, being as hard or harder than ivory, with the outer surface indented and marked as though they had been carved by a Japanese artist.

When set in silver, selected samples of these shackles form very beautiful ornaments for ladies' dresses, and I certainly would advise my lady readers who are always looking out for something new and pretty to try the effect of sturgeons" "shackles" when worn as ornaments.

As is well known, caviare is composed of the roe of sturgeon; and here is a good story about caviare-it is told of a certain well-known learned professor. A friend about to travel in Russia called upon the professor to know if he could collect anything specially for him in those distant parts; the traveller was requested to collect specimens of the Russian fishes. After the lapse of some months a barrel was received by the professor at the College of Surgeons; no letter or description came with it. The professor, forgetting all about his Russian friend, opened the barrel, and found a greasy-looking mass, not unlike soft soap; he carefully examined it, but could not make much of it, so he placed it in a huge bottle, which was filled up with methylated spirits of wine, and corked down. It was labelled, "Roe of fish, locality and species unknown." After a while the traveller returned, and, calling on the 
professor, asked if he liked the specimen of Russian caviare he had sent from St. Petersburg; it was the very best that could be obtained, and was grand eating. It then suddenly struck the savant that the bottle containing the "roe of a fish, locality and species unknown," must be this very caviare, and so it proved to be ; of course, being saturated with spirits of wine, it was quite spoiled for the table.

\section{SUN-FISH.}

(Orthagoriscus mola.)

Through the kindness of Thomas Ledger, Esq., of Folkestone Harbour, I received, in December, 1868, a fine specimen of the Sun-fish (Orthagoriscus mola). $\mathrm{Mr}$.

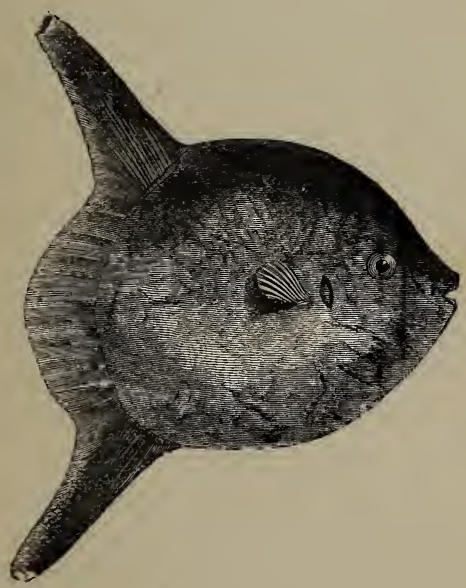

SUN-FISH.

Ledger received it from the chief boatman of the coastguard station at Sandgate. In shape, as my readers 
will perceive, the sun-fish is sun-like. If they wish to make a portrait of him they have only to utilize the inner surface of their own hand, imagine all the fingers taken clean away from the palm of the hand, draw a fish's eye on the skin at the base of the fore-finger, and a pectoral fin in the centre of the palm, erect the thumb as high as possible, and imagine another thumb to match affixed directly opposite the upper one to the lower part of the palm, and you have a fancy portrait of this curious sunfish, fins and all.

The sun-fish has an exceedingly small mouth, and the jaws, when cut out, resemble the jaws of a turtle. He has no teeth; instead of teeth I find simple prominences like coarse sand-paper; the edges are covered with a hard cutting enamel, and the lower jaw is shaped like the beak of a turtle; the stomach is rather large, the intestines very long and much convoluted, the liver not very large in proportion to the fish. All curious and rare fish seem to make a point of being caught before their dinner, as it is very rare indeed to find anything in their stomachs, and this was the case, as usual, with the sun-fish. I cannot, however, help fancying that from the structure of his teeth and intestines he is a vegetable feeder. The eye is very large, and from the size of the muscles attached to it, it must be capable of quick motion. I fancy he must live amongst the dense forests of seaweeds that grow in the submarine valleys in the tropical seas-a kind of subaqueous hippopotamus. He may also eat corallines. Mr. Couch mentions a case of a fragment of coralline being found in the mouth of a specimen caught off the Scilly Islands. In September, 1867, I found the claw of a minute lobster in the stomach of a sun-fish. Sun-fish generally appear upon our coast in the summer months; 
it is therefore rare to find them so late as the month of December. I suppose this Folkestone specimen missed the last train and came by the carrier's cart. The skin is exceedingly hard, like shagreen : in fact, all the bony matter seems to be concentrated in the skin. On dissecting the fish I found it was composed almost entirely of a hard fatty substance, in section very like a flitch of bacon; the muscular substance was very white, and there was a very little of it. I do not wonder that this fish is so much sought after for its oil. I am told that when seen at sea he is generally asleep, or pretending to be asleep, but when the harpoon is suddenly thrust into him he is awake in a moment and can swim off at a tremendous pace. When casting this fish I was in rather a difficulty. The fish itself being soft, I was enabled to tumble him down the stairs into the casting room easy enough, and we could bend him to get him round the corner. The mould, however, with the fins extended, was so long, so heavy, and of course so inelastic, that with the help of the dustmen I had the greatest difficulty to get the cast out of the dissecting-room. The total measurements of the fish were, from tip of fin on the back, to tip of fin on belly, four feet eight; from nose to stern, three feet five and a half, and four feet two in circumference. I could get no scales to weigh him, so (deferring the task till late at night) we cut him up into junks and weighed them separately. We calculate, that altogether, he weighed close on a hundredweight. I packed off the junks of his flesh in sacks to a friend. This gentleman's pigs are among my best friends, as they are particularly fond of fish, and eat up many of my specimens when I have done with them.

In my museum is a magnificent photograph of a sun-fish, taken August, 1870, in Swanage Bay; extreme 
length six feet ten inches, extreme depth four feet five inches, girth nine feet. He was covered with parasites. During the week ending August 13, 1870, I received records of no less than four sun-fish visiting the south coast of England within a few days of each other.

The cast of this Folkestone fish is in my museum, and also a harpoon as used for spearing "sun-fish." It must be remembered that the "sun-fish" of the west coast of Ireland is the basking shark. (See page 214.)

The Oblong Sun-fish is much more rare than the former. It resembles it closely, excepting in its much more elongated shape, the entire length being nearly three times the depth of the body. It grows to a great size, and the flesh is very rank. It feeds on shell-fish.

\section{THE SURMULLET. RED MULLET.}

Acanthopteri.

\section{(Mullus surmuletus.)}

Mullida.

German: Die Meerbarbe, Die Seebarbe. Swedish: Rodfisk. Dutch: Harder. French: Surmulet, Ruget.

The Surmullet, or Sea Woodcock, is of frequent occurrence on our southern coast, and are caught by the

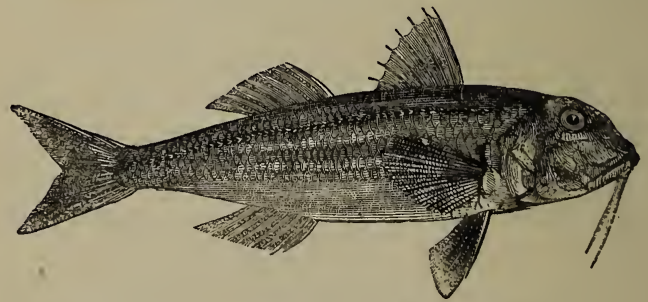

RED MOLLET (IIullus minor, MIullus barõatus).

Brixnam trawlers. It is migratory, and is principally found in the markets in May and June, when its 
colours are most vivid and tho fish in finest order. Red Mullets seldom or ever come into market with their scales on. Mr. H. Lee informs me that the fishermen scrape off the scales with the thumb nail directly the fish are caught. The bare skin then becomes a brilliant red. The average size is from twelve to fifteen inches in length. Sometimes they are caught in great profusion, and at others are very scarce. In August, 1819, 5,000 were taken in one night in Weymouth Bay. The flesh is firm and of good flavour, somewhat resembling the meat of the lobster, and is reckoned easy of digestion. These fish are destitute of an air-bladder. Their food appears to be selected. from among the crustaceous and molluscous animals. They are furnished with two long barbules or feelers hanging from the under jaw, appendages not uncommon in other fishes. These cirri, as they are called, are organs of touch.

\section{SWORD-FISH.}

Acanthopteri.

(Xiphias gladius.)

Xiphiadd.

German: Der Schwertfisch, Der Hornfisch. French: L'Espadox, Dutch: De Zwaardvisch. Danish: Svardfisk. Italian: Pesce Spada.

A FINe specimen of the Sword-fish was caught at Leigh, near Southend, in November, 1866, the well-known quarters of the Thames shunting boats. Mr. Towell, fishmonger, 33, Strand, allowed me to make a cast of it. The fish had been seen about in the river for some days. The dimensions of this fish were-length, including sword, 8 feet $8 \frac{1}{2}$ inches; depth, 1 foot $7 \frac{1}{2}$ inches; length of head, 1 foot 3 inches; eye, 3 inches; dorsal 
fin, 1 foot 3 inches; lobe of tail, 1 foot 5 inches ; sword, 2 feet 9 inches, very sharp, pointed, with cutting edges, and not unlike a Scotch claymore. When dry the skin upon it feels like velvet to the touch. The use of this sword is by no means certain. An ancient Latin author tells us this sword is used by the fish to get his dinner, as he feeds on fish which he kills by charging with his beak; but how does he rid himself of his prey thus transfixed like larks on a skewer? The sword-fish is not a very uncommon visitor to the British shores in the summer and autumn; its home proper is in the Mediterranean, and there is a regular fishery off the

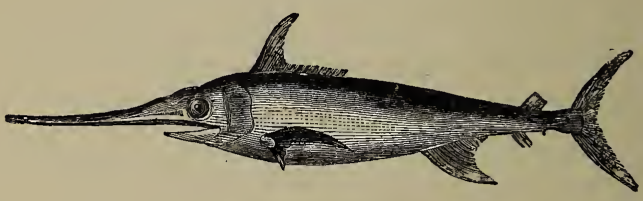

SWORD-FISH.

coast of Sicily, lasting from May to August. The flesh is considered a great delicacy by the Sicilians. I am anxious to know more about the fishery for this Pesce L'Espada, as they call the sword-fish.

In 1868 I received from a friend two fine specimens of swords. When at Constantinople he saw a large number of sword-fish exposed for sale in the public market; as many as thirty fish had been caught in one day in the Sea of Marmora. The fish in the market ranged from three to five hundredweight. They are good eating, and realise about 1s. $9 \mathrm{~d}$. a pound. The swords sent were respectively $22 \frac{1}{2}$ inches and 24 
inches in length, 2 inches in width at the base, and $1 \frac{1}{2}$ inches at the point. Doubtless this sword is useful to the owner. The fish cannot be always fighting, and probably its proper use is that, as the fish lives upon minute sea-creatures, he turns up the sand, \&c., with his sword to hunt for them. By breaking off a small portion of one of the swords I discovered two minute holes in the substance of the bone, and by blowing down the smoke of a cigar, I found that the holes ran completely through from one end of the sword to the other. Besides these two holes, there is also a cavity in the centre. I believe that when the fish is alive this cavity contains nerves. At the lower end I discovered remains of the cellular bone, known to anatomists as the æthmoid bone, and upon which large nerves ramify themselves. These, I believe, are the nerves of sensation which assist the operations of the fish when he uses the sword to rout up the mud and sand for his food. The teeth of the sword-fish are very minute, and not suited for grinding or prehension.

Mr. H. Dearsley, of Salutation-court, Billingsgate, was kind enough to inform me that in July, 1879, he had received a sword-fish from Brighton, and that he had sold it to Mr. Mills, the well-known fish merchant, whose place of business is immediately opposite the Great Eastern Railway Station, Liverpool-street. The following were its dimensions: from the front of the eye to the end of the beak, 2 feet 11 inches; from front of the eye to end of tail, 5 feet 8 inches; and total length, 8 feet 7 inches. The intestines had unfortunately been removed, which I regret, as I was anxious to see what this creature had been feeding on.

Another species of sword-fish (Histiophorus* gladius) is

* The Spear-Bearer. 
found in the Indian Ocean. This fish has a round solid sword, and not unfrequently attacks ships, charging them with wonderful velocity ; but, fortunately, the ship generally comes off best in the fight, as the fish usually manages to leave his weapon behind, sticking fast in the ship. There is a specimen of this fish in the British Museum, with a fin running down its back like a horse's mane, hence the name of "crested." At the College of Surgeons there is a section of a bow of a South Sea whaler, once H.M.S. Fawn. In it is seen the end of the sword of a sword-fish, measuring one foot in length and five inches in circumference. At one single blow the fish had lunged his sword through and completely transfixed $13 \frac{1}{2}$ inches of solid timber. The sword had, of course, broken off in the hole, and thus prevented a dangerous leak in the ship.

In the British Museum is a specimen of a ship's side with the sword of a sword-fish fixed in it-this formidable weapon has penetrated no less than 1 foot 10 inches into the timber. When His Majesty's ship Leopard was repairing, in 1725 , after her return from the coast of Guinea, a sword of the sword-fish was found to have gone through the sheathing, 1 inch, next through a 3 inch plank, and beyond that $4 \frac{1}{2}$ inches into the firm timber, solid oak. It was the opinion of the mechanics that it would require nine strokes of a $251 \mathrm{lbs}$. hammer to drive a bolt of similar size and form to the same depth in the same hull; yet this was accomplished by a single thrust by the fish. Sword-fish are said to attack whales; but we want further information on this point. (See Appendix No. 5.)

In December, 1870, Mr. Thomas Johnson informed me that when the ship Mary Amn Moore, of Dundee, just recently arrived from Bombay, was in dry dock at 
South Shields, the workmen were surprised to discover a portion of the spear of a sword-fish. The spear had. gone completely through the $4 \frac{1}{2}$ inch elm plank and had penetrated two inches into the solid oak timbers behind. I had hoped to have obtained this specimen, but was disappointed. I have, however, in my museum a very fair specimen of a sword-fish's spear cut out of a ship's timber.

\section{SWORD-FISH IN COTRT.}

In the Court of Common Pleas, in December, 1878, a very interesting case of De Garis $v$. The Mercantile Marine Insurance Company, was tried before Lord Chief Justice Bovill.

The plaintiffs, Messrs. De Garis and Arthur, in July, 1863, insured their ship Dreadnought for $£ 3,000$ with the defendants. On the 10th of March, 1864, she set sail from Colombo for London with coffee. On the afternoon of the 13th they hooked a fish which broke the line, and a moment after threw several feet of its body out of the water, and was seen with the line attached. It was a sword-fish, and at four the next morning, the mate awoke the captain, and told him that the ship had sprung a leak. The water was pumped out two or three times, for it was found that she made from nine to ten inches an hour. The captain took the ship back to Colombo, and thence to Cochin, where the ship was hove down. On her being turned over, the surveyors discovered a nearly round hole, about an inch in diameter, and it went completely through the copper sheathing and the planking, but not through the lining of the ship. The captain brought home the perforated plate, which is now in my fish museum.

The case for the plaintiffs was, that the sword- 
fish did the damage; and their learned counsel stated that sword-fish attacked whales; and, not unfrequently, they mistook ships for whales, and attacked them. The damage in this instance was within a foot or two of the keel, and the sum claimed by the plaintiffs was $£ 5845$ s.

The defence was, that the plaintiffs had failed to show how the injury to the ship had been caused. The hole which had been spoken of, it appeared, pointed somewhat upwards and towards the stern of the ship, and it passed diagonally through a three-inch oak plank. No doubt sword-fish sometimes pierced ships; but when they did so, the sword broke off and remained in the ship. It could hardly be imagined that the fish could withdraw his sword from the pinch of the oak plank, and especially so as, in this instance, the onward motion of the ship would tend to force the fish against the ship, and not from it. Under the policy, the plaintiffs could recover only for injury "caused by contact with some substance other than water." The verdict was to this effect. To my mind a most unsatisfactory solution of the difficulty.

Abdominales Malacopterygii.

\section{TENCH.}

Cyprinida.

(Tinca vulgaris.)

German: Die Schleihe, Schleierkarpfen. French: La Tanche. Dutch : Zeelt. Italian: Tinca.

IT is a remarkable fact how the human mind seems to delight in fallacies. There are certain stories, many of them of great antiquity, which are continually cropping up, and to which vitality is imparted by modern books, which again are copied one from the other. One of these 
is the story started by Isaac Walton, that the Tench is the physician of the pike.

Brown, in his piscatorial eclogues, has put Isaac Walton's words into verse as follows:

"The tench he spares;

For when by wounds distressed, or sore disease, He courts the salutary fish for ease;

Close to his scales the kind physician glides, And sweats the healing balsam from his sides."

This is a regular case of poetical license, and carries out the idea so well formularised by Horace as follows:

"Pictoribus atque poetis

Quidlibet audendi semper fuit æqua potestas."

This old story that pike will not eat tench is a delusion. Mr. Higford Burr, of Aldermaston Park, tells

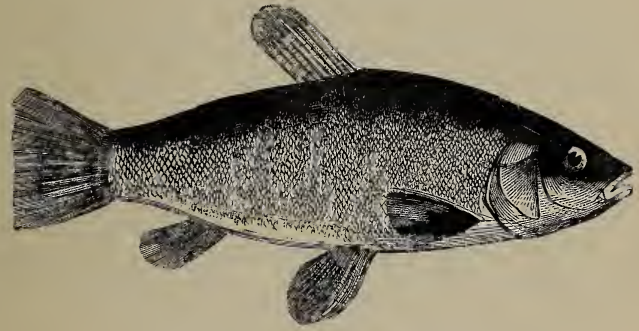

TENCF.

me, "You cannot put a better bait on a trimmer than a young tench. Trout will also eat tench. When drawing my pond, I caught a trout between two and three pounds. Out of its stomach I took twenty-two little tench the size of minnows."

Tench are found in great numbers in Norfolk and Suffolk, in deep, sluggish, muddy waters.

As regards the food of the tench, my late friend $\mathrm{Mr}$. 
Gillbanks, who was a great botanist, writes me: "The natural food both of carp and tench is the larvæ of insects, small worms, and the soft parts of various aquatic plants." When I was at Cambridge, the men who went wildfowl-shooting with me called some of the weed that abounded thereabouts "tench weed." It was one of the Potamageton tribe, on the broad leaves of which tench deposit their eggs, which hatch out in a very few days.

As regards keeping common tench, golden tench, and especially gold-fish, Mr. Gillbanks writes: "The water in which they are placed cannot be too soft. I give my gold fish Ranunculus aquatilis and Ranunculus hederecea - the ivy-leaf sort. The small flowers of these are very pretty, and they take up little room, as the foliage and flowers are at the top, affording shade and harbour for delicate mollusks such as Limneus pereger, the planorbis, the fresh-water limpet, which feed on confervæ and keep the water clear."

Anacanthini Thoracici.

\section{TORSK.}

THE Torsk, or Tusk, is a northern fish, seldom found much further south than the 68th degree. It is only

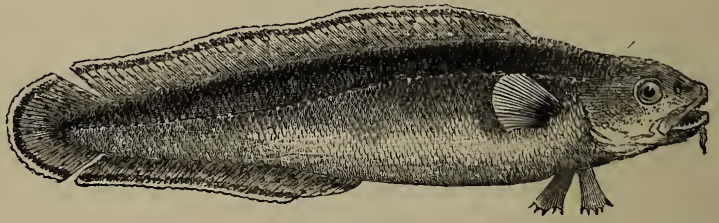

TORSK.

occasionally caught in the Forth, but more frequently in the Orkney Isles, and is plentiful among the Shet- 
lands, where it forms a considerable article in the fishing-trade. When on the Herring Inquiry, 1878, at Lerwick, I obtained much valuable information about this fish. From Lerwick I have received a specimen, a cast of which is now in my museum: it weighed $27 \mathrm{lbs}$. In external form it somewhat resembles the burbolt of the Trent.

\section{THE TRUMPET FISH, OR SEA SNIPE,}

BeLongs to the pipe-mouthed family, which is characterised by a long tube, formed by the elongation of the jaw-bones, at the extremity of which is placed the mouth, which is small and without teeth. Its ordinary size is from four to five inches in length. A few specimens only of this singular-looking fish have been taken in our seas. I have never seen a fresh specimen.

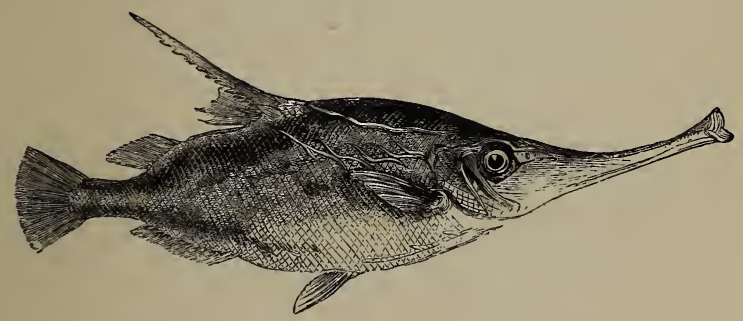

TRUMPET OR SNIPE FISH (Centriscus scolophax).

It is common in the Mediterranean. The beak-like mouth is admirably adapted for detaching minute animals from the various sorts of sea-weeds, and the form of the apparatus renders it probable that, by dilating the throat, it can suck up food as water is drawn up through a syringe. This fish has a formidable 
weapon of defence in the first spine of the first dorsal fin, which is very long and powerful, pointed, movable, and toothed like a saw on the under part. The general colour is a golden-red hue.

\section{TUNNY.}

Acanthopteri.

Scomberida.

(Scomber thynnus. Thynnus vulgaris.)

German: Der Thunfisch. French: Le Thon. Italian: Tonno.

This is a very rare British fish. A splendid specimen was sent me by Mr. George Lamsey, Brunswick Place, Dawlish, September, 1868, which weighed between three and four hundredweight. It measured-length, 8ft. 7in. ; greatest circumference, 5ft. 2 in ; circumference behind great dorsal fin, 3ft. 4in.; spread of tail, 2ft. 4 in. ; eyes, 2 in. in diameter ; pectoral fin, $15 \mathrm{in}$. long,

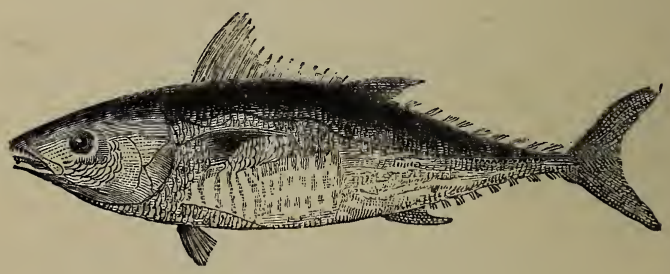

TONNY.

with 36 spines; dorsal fin, 14in. long, with 13 spines; lower dorsal, also 14in., with no perceptible spines; 10 minor dorsal fins between lower dorsal and caudal fin; spines in caudal fin very numerous, gradually decreasing in size from the outer rays to centre; enlargement along lateral line close to caudal fin, 7in. long and lin. 
ligh, composed of muscle, evidently to strengthen the connection (which tapers very fine) of tail to body. The tunny is one of the Scomberida, or mackerel family; in fact, it is very like an ordinary mackerel put under the microscope. The dorsal fin, with its iron-like spines, fits into a depression in the back, just as in the mackerel. The tunny has two kinds of scales, some as large as half-crowns; these are very compactly fitted one to the other, so as to form a skin almost approaching armour in thickness. Toward the lower portion of the body the scales become very small, almost the size of trout scales. My cast of this fine fish is in my museum; the skeleton is in the British Museum. The tunny is very plentiful in the Mediterranean, especially along the coast of Sicily, where the fishery takes place in May and June. The tunny fishery is thus practised in the Mediterranean : A man is stationed on the look-out for the school; when the direction they are heading is ascertained, every effort is made to get the nets across their path, the neighbouring boats rush to the rescue, and at length the drove is surrounded, and the fish appear to lose presence of mind from the first coming in contact with the obstacle. The size to which these fish sometimes grow is enormous; three-quarters of a ton, or even larger, have been taken; but these giants do not seem to agree with their smaller brethren, and lead a solitary life. These large fish are not so very rare, but about $100 \mathrm{lbs}$. is the usual size. It is generally credited that they annually assemble in the summer in the Atlantic, and, as the season advances, pass through the gut of Gibraltar, up the Mediterranean, through the Dardanelles, Bosphorus, and up the Black Sea in immense shoals. As an article of food, the belly portion when fresh is extremely good; the rest of the 
carcase, which looks like beef, is to be found exposed for sale, salted, in almost all Mediterranean towns.

In my museum I have a cast of a small tunny, which measures $4 \mathrm{ft}$. $3 \mathrm{in}$., and weighed about 50lbs. It was given me by Mr. Grove, of Charing Cross, September 30,1868 , and, when eaten, it was agreed by all to resemble very fine veal cutlet. I am very anxious to obtain a specimen of the hard roe of the tunny, to see what size the eggs of this monster fish may be. In May, 1880, Mr. Henry Lee brought me a bone which had been trawled up by the Margate smack, Blanche, when fishing on the Foreland Ground. The bone certainly was a puzzler, but Mr. Lee and myself diagnosed it as being the skull of a very large tunny, an opinion which was confirmed by Professor Flower, of the Royal College of Surgeons. This tunny had probably floated after some accident or natural death, and as the skin decayed, the bones, especially the heavy skull bone, had dropped to the bottom of the sea.

Acanthopteri.

\section{THE BONITO.}

Scomberida.

(Scomber pelamis.)

I HAVE almost invariably remarked when reading books on foreign travel that the author manages to get across the ocean with a very few words of description. Thus the events and the objects seen in the vast Atlantic between Liverpool and New York, or in the great waters sailed over by our friend Mr. Wigram's big ships between London and Australia, are summed up in, say, half a page. That this is a mistake I am quite certain, as in all seas there must be abundance of surface fish, 
and other marine forms of life of some kind or other, which must surely be worth notice.

Amongst surface fish certainly must be included the bonito. I have (thanks to numerous friends and correspondents) now casts in my Musuem at South Kensington of two tunnys and two pelamids, but hitherto no bonito. I was therefore highly delighted when $\mathrm{Mr}$. Searle appeared in my room (August 12, 1880) with a bundle containing a true bonito.

This rare fish was caught at Hawgill, on the Solway, in the estuary of the Eden, in a haaf-net, and sent me

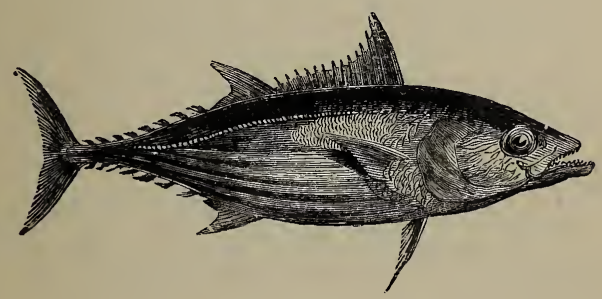

BoNiтo ( Thynnus pelamis, Scomber bonito).

by Mr. R. Aitchinson, of Annan. The fish is very tunny-like in appearance; total length, 2ft.; weight, $6 \frac{3}{4} \mathrm{lbs}$.

The peculiarity of the colouring is that it has four dark blue stripes on either side.

Scomber bonito (Thynnus pelamis) is abundant in the Mediterranean and Atlantic. They catch large numbers of them when fishing for tunny; they also fish for them trailing as for mackerel.

The best time for bonito fishing is from May to the end of September, and the best bait the tail of an eel. Bonitos are great enemies of sardines and flying-fish, 
and an artificial representation of one of these fish is frequently used. One sees these artificial flying-fish, the wings being generally composed of long stiff bristles or hairs, very frequently in the marine-store shops in the neighbourhood of the docks. Bonitos go in shoals of from ten to twenty individuals. They like very deep water, but always swim on the surface.

\section{PELAMID.}

I RECEIVED in 1877, through the kindness of Mr. M. Dunn, of Mevagissey, two specimens of the Pelamid. One was caught in August near the Deadman, the other in September near Gorran Haven. The first specimen measured 17in., and weighed 2lbs. The second specimen weighed $2 \frac{1}{2} \mathrm{lbs}$. and measured $1 \mathrm{ft}$. $8 \mathrm{in}$. The pelamid is very mackerel-like in appearance, and has band-like markings extending from the back to the belly. The lateral line is very crooked. The pelamid is a very rare British fish.

\section{GREAT WEEVER, OR STING-BULL.}

Acanthopteri.

(Trachinus draco.)

Uranoscopida.

German: Das Petermännchen, Der Drachenfisch. French: La

Vive Vipere. Dutch: De Pietermann.

IN the accompanying plate it will be seen that there is a formidable crest or spine just at the back of the head. These are actually poisonous weapons, so that it has been truly called the "Viper," or "Weever" fish.

In September, 1873, I published in Land and Water the following account from a friend living at Nairn, in 
Scotland: "A lady was bathing in the sea near here, Murray Firth, and placed her hand upon the sand beneath the water. Instantly she felt her finger sharply punctured, and found blood oozing from a little hole. In a minute the wound became a dark purple colour, the finger and back of the hand swelled up and turned scarlet, and pain of a most agonizing character extended along the arm. The symptoms lasted three days, leaving soreness and pain. This, of course, was the sting of the weever fish."

I earnestly entreat ladies and children, in fact every one, when bathing in sandy places, to be sure to wear slippers, as the weever fish live in the sand, and. keep-

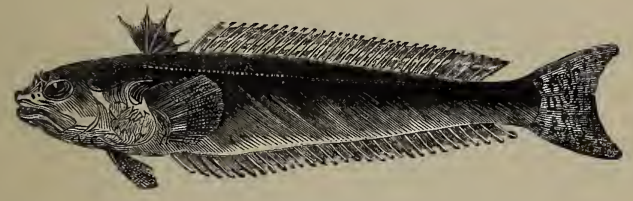

GREAT WEEVER.

ing their sharp poisonous back fins erect, are very likely to wound the foot. The weevers have also a dagger in the sides of the cheek. I have experimented upon them, and I find they certainly have the power of jerking themselves backwards, so as to inflict wounds with these spines. It is worth while to take out one of these spines and examine it. It will be seen that it is connected with the bone of the head by a jiont which gives it great mobility. The spine itself is dagger-shaped, the point as sharp as a very pointed needle, the sides fluted somewhat like a bayonet. I cannot quite make out whether it is or is not perforated like the tooth of a poisonous snake. The fishermen say that the moment 
a person is stung, he should apply to the part the fish's liver. There is another impression prevalent, that the pain in its greatest intensity occurs at the same time of the tide as that when the original injury was inflicted.

As regards the poisonous properties of the spines in the weever fish, my friend Mr. H. Lee has published in Land and Water, August 7, 1870, the following interesting remarks:-

"The dorsal spines are not intentionally used by the fish as means of injury or offence. Its most dangerous weapons are the strong, sharp spines at the upper part of the gill-covers. They point backward when at rest, but can be directed almost at right angles with the body when the animal desires to use them; and it is astonishing with what precision it can bring these spikes into action when touched on any part of its body.

"These spines were formerly supposed capable of conveying poison into the wounds made by them, in the same manner as do the fangs of the venomous snakes. Professor Allman, in the Ann. and Mag. Nat. Hist., writes:-

“" The spines of the opercula will be found to be deeply grooved along the edges, each groove terminating at the base of the spine in a conical cavity excavated in the posterior edge of the bony part of the operculum. In the sides of these excavations the edges of the grooves lose themselves, so that there is a perfect continuity between each groove and the corresponding cavity. From the posterior edge of the operculum the integument is continued over. the spine to within a very short distance of the point, by which means the spine is enclosed in a complete sheath for nearly its. entire length, and the groove at each side is converted into a perfect tube, extending from the conical cavity at the base almost to the point of the spine. I have not as yet been able to detect any specific gland connected with this apparatus. There is, indeed, in each of the conical cavities above-mentioned a small pulpy mass, which may possibly be of a glandular nature; but in ascribing to it the property of secreting the virus $I$ do nothing more than hazard a distant conjecture. It seems, indeed, to be chiefly composed of fatty matter. The property of secreting the virus may probably with more truth be ascribed to the pulpy sheath of the spine; but this, too, is nothing more than conjecture. 
" 'It is quite possible that a fluid or mucus of an irritating or poisonous nature may collect in the longitudinal groove of the spine, and may be introduced into the wound by contact; but there is nothing in the structure of the spine itself or of its basal attachments to justify the supposition that a venomous fluid can be injected by it. Whatever may be the nature of the virus, it is certain that a puncture by one of these spines sufficiently deep to draw blood is generally followed by much pain and inflammation, as I know from experience." "

Should any of my readers unfortunately be wounded by a viper fish, I recommend fomentations of hot poppy decoction, followed by poultices, with laudanum. Salvolatile in dram doses should be taken every two hours.

\section{WHITEBAIT.}

THe following account of Whitebait is given from the Appendix to the "Report on the Sea Fisheries of England and Wales, 1879," (1. 2449), in which I give a short history of each of the fish mentioned in the Report :-

The whitebait which comes to the London market is caught principally at the following places:-Gravesend,

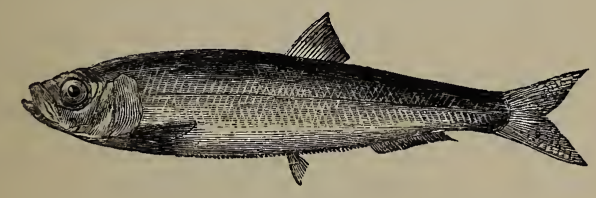

WHITEBAIT.

Queenborough, Leigh, Southend, Shoeburyness, and Burnham (Essex). The nets used for catching whitebait are stowboat nets, peterboat nets, and seines.

The money expended in the actual capture of whitebait is altogether of very considerable amount. There 
is hardly a fishmonger in London who does not sell whitebait when in season.

The principal whitebait merchant in Billingsgate is Mr. John Welch, who has 12 boats at Southend, 6 at Gravesend, 5 at Leigh, and 5 at Greenwich. The share of wages which he pays is $£ 60$ to $£ 70$ per week, and the firm pay about $\$ 100$ per week in wages. The total amount spent in the catching of whitebait is from $£ 1,500$ to $£ 1,800$ a year.

At Queenborough we were informed that about $£ 40$ per week, or $£ 2,000$ a year, is coming into Queenborough as wages for the fishermen catching whitebait.

Whitebait being par excellence the rich man's fish, we were told at Queenborough by William Hoskins, fisherman of that place, that whitebait fishing " begins when Parliament meets, and finishes when Parliament is adjourned." The general season for whitebait may be stated to be from February to August. Whitebait fetches from 1s. to 2 s. a quart wholesale. The average number of whitebait caught during the season is about half a ton a day.

On the 4th June, I saw at the Fenchurch Street station no less than 28 flat baskets full of whitebait. The baskets were shallow and open, and fish were spread on the baskets to the depth of about $2 \mathrm{in}$. I made a calculation as to the number of whitebait in these 28 baskets, and estimated that they contained between 600,000 and 700,000 young fish.

I bought a shilling's worth of whitebait in a London shop, and found 204 fish, weighing altogether $18 \mathrm{oz}$.

This, therefore, shows that whitebait is rather cheaper than butchers' meat at 1s. per pound.

Mr. James Henry Cannon, an old man who had been fishing for sixty years, gave us some very interesting: 
information relative to the first introduction of whitebait as a general food. An ancestor of his, Robert Cannon, "invented" whitebait in 1780 , and for many years had been the only fisherman in the trade. The following is Mr. J. H. Cannon's account, which is now historical :

"It may be interesting to know who really was the originator of the now extensive 'Whitebait Fisheries' ; I therefore, in justice to the memory of my predecessors, deem it my duty to assert, and can incontrovertibly prove, that my grandfather, Mr. Richard Cannon, Thames fisherman, of Blackwall, was the first and only man who, in the year 1780, brought that delicate fish (to which he gave the name of whitebait) before the notice of the hotel and tavern keepers at Blackwall and Greenwich, at which places the first whitebait dinners were served.

"For some years he was the only one in the trade, as he had serious obstacles to overcome, from the interference of the Thames Conservancy, who forbade the fish to be caught, under the impression that it was the fry of herrings, shad, \&c., until, eventually, my father, Mr. Richard Thomas Cannon, only son of the above, attended before the then Lord Mayor, and proved to the complete satisfaction of his Lordship ' whitebait' to be a distinct species of fish, and not the fry of any other, however similar in appearance.*

* I am reminded by Dr. Day, late Inspector of Fisheries in India, that Pennant in his British Zoology, 1776, mentions whitebait as follows: "During the month of July there appear in the Thames near Blackwall and Greenwich innumerable multitudes of small fish which are known to the Londoners by the name of whitebait. They are esteemed very delicious when fried with fine flour, and occasion, during the season, a vast resort of the lower ordcr of epicures to the taverns contiguous to the places they are taken at." 
"In the year 1798 my father, Richard Thomas Cannon, succeeded my grandfather in the business, and supplied the whole of the hotels and taverns at the above-named places, and all the leading fishmongers in London.

" He had the honour of supplying His Royal High. ness the Prince Regent, at Carlton House, and from the year 1820 (when His Majesty King George the Fourth ascended the throne, until 1830 ; during the ten years' reign of that monarch), my father supplied the royal table with whitebait every day throughout each successive season. He had also the honour of supplying His Royal Highness the Prince Leopold (His Majesty the late King of the Belgians), the Foreign Ambassadors, and most of the nobility in London. I had the honour of taking the fish to Carlton House, St. James's Palace, \&c.

"I have succeeded my father in the business nearly forty years, and have supplied the hotels and taverns at Greenwich and Blackwall, up to the present time.

"I have supplied the Brunswick Hotel, Blackwall, for thirty-irve years successively.

“ 1878.

"James Henry Cannon."

The use of these fish as bait (before utilized as food) directly affected the fisheries of the North Sea in the following curious manner. The whitebait were used as bait in crab pots for catching the common shore crabs. These crabs were used for catching whelks in the estuary of the Thames by the process called "trotting," and finally the whelks were (and still are) of very great importance for catching cod in the North Sea.

When used as "bait" these fish-as now-were bright and silvery, and were called white-bait, in contradistinction to other baits that were not white. When 
they became fashionable as food for Londoners they still retained their name " whitebait," by which appellation they will probably be still known at ministerial dinners, city feasts, and private dinner parties, for years to come.

The origin of the word whitebait having been thus accounted for, I now proceed to state of what kind of fish whitebait consists. The evidence of the different witnesses may be classified as follows:-

1st. That they are a fish of a distinct species.

2 nd. That they are young sprats.

3rd. That they are young herrings.

4th. That they are "whitebait" without further definition.

Having for many seasons past paid serious attention to the subject of whitebait, I now beg to give the results of my investigations. In the whitebait nets, according to the season, may be found the following eleven kinds of fish all more or less in the fry state :-1, herrings ; 2 , sprats; 3 , gobies; 4 , weevers ; 5 , sand-eels ; 6 , smelts ; 7 , pipe-fish; 8 , sticklebacks ; 9 , buntings or brown shrimps; 10 , red shrimps ; 11 , gorebills or garpike.

According to the season these fish are found in various proportions. As I stated before, the fishing commences in February, and goes on to the end of August. It then stops because there is no sale for the fish. If a basket of whitebait be examined in April there will be found a large number of minute fish from 1in. to $1 \frac{1}{2}$ in. long, perfectly transparent, with a large eye and no scales visible, the body being covered with a few black spots. These are called "smig herring."

Towards the end of the month the scales begin to appear on some of these young fish in the form of a band of silver along the edge of the abdomen. 
Towards the middle or end of May the young herrings will "take scale," and the warmer the weather the quicker they will grow. The herrings are of various sizes, the smallest being like a minute thread or small slip of isinglass. The largest herrings are from 4 to 5 inches long, and weigh four to the ounce. The larger ones are caught in the early part of the season, more particularly in February or March, and are called. "yawlings," a corruption of the word yearlings, signifying that the fish are one year old-a theory in which I agree.

Yawlings go in March or April to the sea, and are again heard of about June the same year as "spring herrings." In the autumn of the same year (or more probably in the next year) they will lay their eggs.

I believe that none or very few of these "yawlings" are sent to the London market when caught with the "bait" at the early part of the season. They die when caught in the net, and are thrown again into the water. The reason assigned is that they are not marketable like the small " spratty stuff." This destruction of yawlings is certainly a great waste of food. If yawlings are inquired for and purchased by the public, the fishermen will not throw them overboard, but sell them to the fishmongers, and thus the food supply of Londoners may be considerably increased by the sale of yawlings. Among the whitebait, as I have said, there are a great many sprats. This is called "spratty stuff." The spratty stuff and the "smig" bait comes up the river first. The run of fish varies very much according to the temperature and the state of the river and sea outside. The sprat in the fisherman's language is "snugger in the head" than the herring, and its body is rounder, but the difference between the minute sprat 
and minute herring is not easily explained unless with fresh specimens to hand for illustration. The young sprats will keep much longer than the young herrings. The herrings break, that is, they burst open much sooner than the sprat.

The "Rooshians" which come into the river about May are the young of the weever fish; they have little colouring and are very jelly like. They are called Rooshians because they were caught in great abundance in the river in the time of the Russian war.

In the spring of the year a great many sticklebacks are caught; they are generally of a beautiful silver colour, and sometimes "golden sticklebacks" are taken.

Among the whitebait many small shrimps are also. taken; some of these are buntings or brown shrimps, some are red shrimps. The red shrimp "carries a sword in his head," and boils almost the colour of a prawn; the bunting does not carry a sword, and boils brown.

The young of the spotted goby are also found amongst whitebait, and are called "polwigs;" and various kinds of minute fish, just hatched out, are caught, which are difficult to identify, and are called " heads and eyes."

The pollutions of the Thames have a great effect upon the progress of the whitebait up the river. A witness at Gravesend informed us that whitebait used to be caught at Blackwall, but that they have dropped gradually from Blackwall to Woolwich, from Woolwich to Erith, from Erith to Grays, from Grays to Gravesend, and from Gravesend to Southend. They are now principally caught in the Lower Hope and the Medway.

The warmer the season the better the whitebait. The little fish are surface swimmers, and swim high in warm weather, lower in cold weather. 
I have thus endeavoured to describe some of the different kinds of fish that are sold as whitebait. If they are sprats there is no reason for stopping their capture, as sometimes sprats are caught in such large numbers in the mouth of the Thames as to be useless, and many barrels of "garvies" or sprats are sent to London from the Firth of Forth, and other parts of Scotland.

Sprats, again, are worth $9 \mathrm{~d}$. a bushel, and are often sold as manure at even a less price, while whitebait is sold for food at $£ 3$ per bushel.

If they are herrings it is not necessary to prevent their capture, as there are no herring fisheries nearer the mouth of the Thames than Lowestoft to the North, and Folkestone and Ramsgate to the south, and herrings are not shown to have fallen off anywhere with the exception of in the Pont. Even if a decrease of herrings was found, it is exceedingly doubtful whether the sparing of the whitebait would increase the quantity.

I am of opinion, therefore, that the whitebait fishing should not be interfered with, as a considerable number of fishermen are employed in the business-large sums of money are expended in boats, tackle, \&c., for its capture - and whitebait has now become almost a necessary food for the people of London.

\section{WHITING.}

Anacanthini Thoracici.

\section{(Gadus merlangus.)}

Gadida.

German: Der Wittling. French: Le IIerlan. Dutch: Die Weiting. Norwegian: Hvitting. Danish: Hvidling.

The Whiting is the most delicate in flavour of the cod tribe. It is caught in great abundance almost all round our coasts, and ranges from the Orkneys to Cape Clear, swimming in large shoals a few miles from the 
shore. The usual weight is about $1 \frac{1}{2} 1 b s$. In its habits it is a very shy fish.

The whiting is taken in greatest quantities on the southern coast of England, particularly off Plymouth; and the market at that place was sometimes formerly completely glutted. Of late years they are packed off to London as soon as landed. With the single exception of the mackerel, he suffers more than any salt-water fish from packing and carriage ; and is, indeed, a more delicate fish than the mackerel, and should be eaten as soon as possible after being caught. Off the coast at Dartmouth very fine whiting are taken, from $2 \mathrm{lbs}$. to 3lbs. in weight; the fishermen then dry them in the

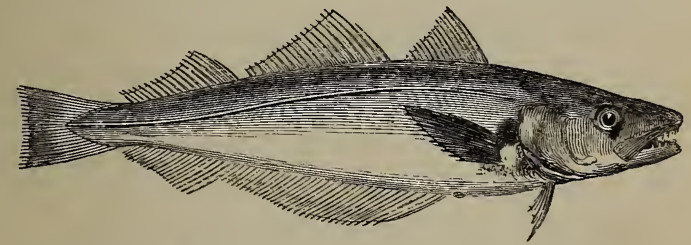

WHITING (Merlangus vulgaris Gadus merlangus).

sun, and they are then called "buckhorn," and by many considered superior to the fresh-caught fish.

The eye of the whiting is very large, and on opening it with a scalpel before cooking, the lens will be found to consist of the most beautiful crystal-like material it is possible to conceive; the lining membrane of the sclerotic coats of the eyeball is also exceedingly beautiful.

\section{WRASS.}

The following are the various species of British Wrasses :-

Labrus :-Ballan Wrass (Turdus, Labrus maculatus); 
Green Streaked Wrass (Labrus lineatus); Comber Wrass; Cook, Cuckoo Wrass, Blue-striped Wrass (Labrus variegatus, Labrus coguus, Labrus mixtus) ; Threespotted Wrass (Labrus trimaculatus); Sea Wife (Acantholabrus Yarrellii).

Acantholabrus :- Scale-rayed Wrass (Acantholabrus Couchii, Labrus luscus) ; Rock Cook (Acantholabrus exoletus, Labrus exoletus); Corkwing (Labrus cornubicus, Crenilabrus cornubicus); Baillons Wrass (Crenilabrus Baillonii); Jagos Goldsinny (Crenilabrus rupestris).

Julis:-Rainbow Wrass (Julis vulgaris, Labrus julis).

Wrass may be found along our coast in rocky places, especially where there is much seaweed. I first learned to fish for wrass at Guernsey, where they abound. Take a long piece of string, unravel about a couple of yards of the end, so that there is a single strand only. To this tie a common beach pebbie, attach the hooks to the string, so that when in the water they shall stand at right angles to it. Coil up the string neatly on to the rock; swing the stone round three or four times, let it go suddenly, and it will carry the string, hooks and all, well in among the rocks and weed. When you have a bite, strike smartly. As you are fishing among rocks, the probability is that the stone will get jammed among the rocks; pull smartly, and break the single strand, leaving the stone in the sea. In this way excellent sport can be obtained.

When you have caught your wrass examine his mouth; he has wonderful prehensile lips, reminding us of the lips of the giraffe. His mouth is a wonderful piece of mechanism, sliding backwards and forwards like a telescope ; the use of this is to enable him to pick up from the crevices of the rocks the periwinkles and other shells on which he subsists. His teeth are 
wonderfully strong and admirably adapted for their work. In the gullet there is a pavement of lovely white teeth, in shape like the dome of St. Paul's, and their use is to grind up the shells. The wrasses wear a Jacob's coat of many colours, and form an excellent subject for those who can handle the paint-brush, whether in oil or water colours.

The Gilthead (Labrus rupestris) is not an uncommon species, and is often taken in lobster and prawn-pots; as is also the Goldsinny (German : Seekarausche), which is readily distinguished by a conspicuous black spot on each side of the tail ; it is sometimes called the Corkwing, as it is a minute fish, not exceeding two inches in length. It haunts the sea-weed on all part of the British coast. It is always in motion, and puts itself into very pretty attitudes, as it perseveringly hunts among the sea-weeds for its insect prey. It makes a nice aquarium fish.

As regards the Blue-striped Wrass, Mr. Reed, of Wick, writes, June 4, 1870 : “No less tlian five speci-

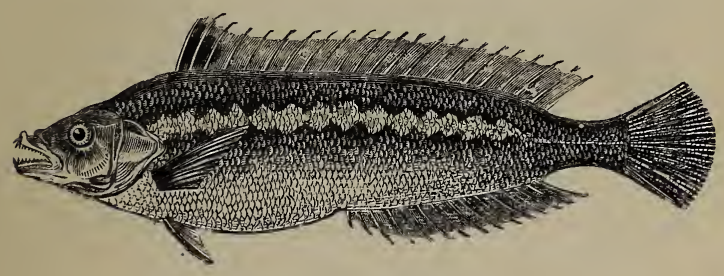

RAINBOW WRASS.

mens of the blue wrass were taken on haddock lines in one day, in June, 1870, at Wick, by a fisherman; the fish was quite new to this coast, and had never been observed before; one specimen measured upwards of fifteen inches. The colours of the wrass soon fade away after exposure to the atmosphere." 


\section{SALMONID $\mathrm{E}$.}

\section{THE SALMON.}

(Salmo salar.)

German: Der Lachs, Der Salm; Spawning male-Hakenlachs.

Danish: Lax. Norwegian: Laexing. Swedish: Hafslax, Blanklax. Dutch: De Zalm. French: Le Saumon.

For many years past I have scarcely done anything else, either officially or privately, except to attend to, and carefully watch, the interests of the King of fish, the Salmon, the great Salmo salar.

I find, therefore, the greatest difficulty in selecting from the mountain of information which exists on the subject of salmon fisheries and salmon legislation.

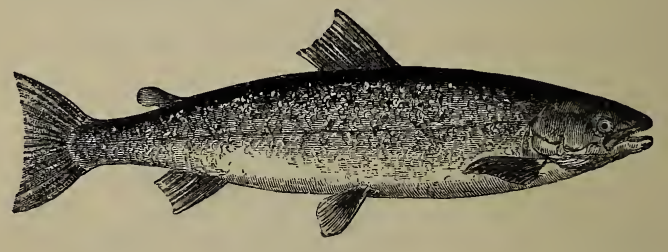

SALMON.

The history of the salmon should be properly written as follows:-1st. Its Natural History; 2ndly. Its Economic Value; 3rdly. Legislation, both past and prospective.

In order to do this thoroughly would require a volume of itself, but as this book is meant as a familiar history of fishes, I think it would be best not to attempt any classification of the various subjects, but to divide what I have to say into little treatises, as it were, each 
of which I have made as complete as I can. I hope one of these days to write a separate memoir of my good friend the Salmon.

I must, however, here give a short outline of the history of the salmon. I consider the salmon to be a sea-fish proper; nevertheless, this sea-fish ascends the rivers and streams in order to deposit its eggs, for unlike other sea-fish it does not breed in the sea. Secondly. Having ascended to fresh water, it deposits its eggs on gravel, where in due course they hatch out and become young fish. Thirdly. These young fish, after a certain time, descend to the sea as smolts in the months of May and June; some of them migrate the first year, some the second, and some the third. These small fish, having arrived at the sea, remain there a certain time -some a few months, some a year; they then begin to return to the river as grilse. The parent salmon, having spawned, descend to the sea in a wretched and miserable condition, many dying on the road. These are called "kelts" or "slats." They then recover their condition and return again to the rivers. In every stage of their existence, salmon are surrounded by enemies innumerable, and it is really wonderful that they do not become extinct. They are, however, so prolific, that when care is bestowed upon them, and their enemies kept under as much as possible, they will increase in numbers and size in a most wonderful manner.

Every female salmon, as a rule, carries about 900 eggs (the hard roe is the eggs) to a pound of her weight; thus a $361 \mathrm{lbs}$. fish would contain 32,400 eggs, a number exceeding the population of Reading, i.e., 32,313. A great many casts of salmon containing eggs can be seen at my museum. In all cases the weight of the fish and the number of eggs are given. 
It will be perfectly impossible to understand aright the natural habits of the salmon unless we regard them from the proper point of view, viz., that the goings and comings of these curious migratory creatures are independent of human interference, and that they simply obey the Divine laws which have been laid down for them from the beginning of time.

In the whole history of the salmon we may discern a wonderful order and foresight on the part of the Creator. The parent fish run up the rivers when the floods are coming down. These floods enable them to reach the only places which are fit for the hatching out of their ova. Floods also cover over entirely, or else reduce to a minimum, the height of the weirs, and dilute the pollutions from town sewage, from paper and other manufactories. Cold water is necessary for the development of the ova when deposited (the temperature should be from $44^{\circ}$ to $48^{\circ}$ ), and this low temperature occurs only in the winter months, at which time the fish deposit their eggs. The young fish come out of the egg with their food provided for them in their umbilical vesicle. The albuminous contents of this provision bag being gradually absorbed, lasts them till they are grown large enough to catch their own food. In the spring of the year this food appears abundantly in the form of insect life. The parent fish, which have risked their own lives for the benefit of their young, drop back to the sea to recruit their exhausted strength,* and both they and the smolts (their

* In this state a large number of fish are annually found dead; having examined a large number of them, I can find no cause of death except an anæmic condition and a laxity of fibre in the muscular tissue. I conclude, therefore, that the natural cause of death is (except in cases of violence or wounds from fighting) simple exhaustion; most of these fish found dead are males. It 
young) arrive in the sea just about the very time that there is most food for them. The sea-fish mostly spawn during the spring months, and from this source, therefore, both the kelts and the smolts derive abundance of nutritious food. These provisions show an admirable "police of Nature," by means of which various kinds of fish feed on each other, and are kept in check, while all are made to reach a high state of development.

\section{MONSTER SALMON.}

For several years past I have, by the kindness of London fishmongers-especially Mr. Thomas Grove, of Charing Cross; Mr. Charles' of Lower Grosvenor Place, Pimlico; Messrs. Gilson and Quelch, Bond Street; Messrs. Grove, Bond Street; Messrs. Smithers, London Bridge Railway Station; Mr. Towell, Strand, \&c.-been enabled to cast nearly all the monster salmon that have come to the London market. I generally have the fish sent up to Albany Street in the evening, and I can now (having had so much practice) cast a mould and return the fish uninjured in about two hours; the process of casting does not injure the fish in the least, sometimes not a scale is rubbed off.

The following is a catalogue of the largest salmon I

is very possible that the law of Nature is that the large males shall die in certain numbers, and thus leave room for the smaller males to keep up the breed. The females are found dead much more rarely than the males; these facts may also have some bearing on the interpretation of the male smolt having its milt fully developed, and capable, as I myself have proved by experiment, of fecundating the ova of adult fish. The female smolt has the ova developed in a very minute degree at the time that the male smolt contains ripe milt. 
have in my museum, and I am happy to say the largest. is a British fish :-

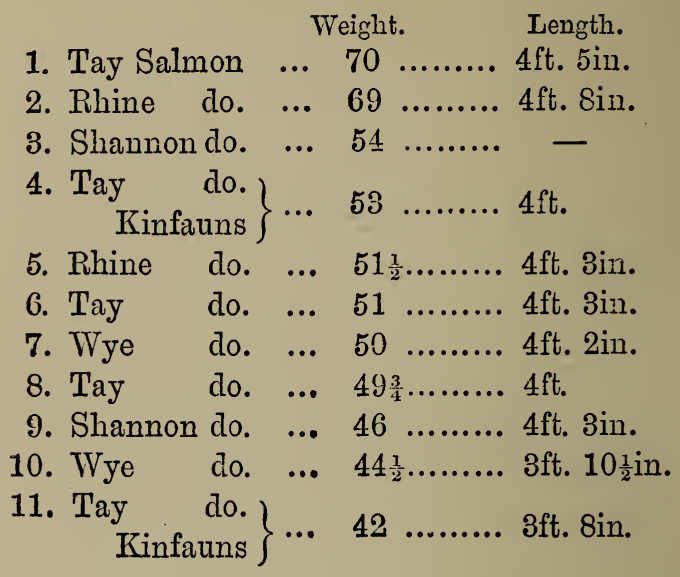

The King of the collection is certainly the 70lbs: salmon from the Tay; it has been marvellously painted. to life by my friend H.L. Rolfe, Esq., of Nicholas Lane, City, and the reader has only to examine it to see the high pitch of art to which Mr. Rolfe has attained in painting fish, and he, I think, well deserves the title. he has so justly earned, "The Landseer among. Fishes."

In Land and Water, June 25, 1870, I wrote the following account of this big fish, the

\section{MONSTER SALMON FROM THE TAY.}

Mr. Charles, of Arabella Row, kindly sent me word. (June, 1870) that he had purchased at Billingsgate a very large salmon, and that he wished me to examine it. I have seen many big salmon, but never saw such a fine "beast"-as the Scotch fishermen call a salmon 
-as our friend from the Tay. He had been caught in the nets of my friend $\mathrm{Mr}$. Alexander Speedie, the energetic and well-known tacksman, of Perth. Mr. Speedie writes me that his men caught the fish on the Haggis fishing-bank, about two miles below Newburg, on the Tay. Wishing to be certain of the weight of this Tay fish, Mr. Charles was good enough to put him in the scales in my presence. He was within an ounce or two of seventy pounds, and he would have turned the scale at this weight, only from exposure on the slab he had become somewhat dry, and therefore lost a little of his weight. I measured him carefully. His total length from tip of nose to edge of tail was $4 \mathrm{ft}$. 5in.; his girth, $2 \mathrm{ft} .7 \frac{1}{2} \mathrm{in}$; and length of head, 12in. Reader, chalk or pencil out these measurements, and you will see what a wonderful fish this was, and he was as handsome as he was bulky. The wholesale price was over £9. I took up the fish to Albany Street. I soon had him under the plaster, and before darl I got a very fair mould of this ling of fishes. I then took him back again to sleep in the ice in Mr. Charles' shop. I did not injure a scale with the casting process, and he tumbled out of his mould like a great bullock. Mr. Charles gave me his head and his inside; of the head I have made moulds with fins expanded, as it will make a capital "gurgoyle." I have filled up his intestines with plaster; their total length is $4 \mathrm{ft}$. Bin., his œsophagus and stomach together. His pyloric appendages were covered with fat, and there was also much fat about his intestines-this latter fat alone weighed 3 ounces. There was, of course, nothing in his stomach, as he had all his fat on board for his summer expedition up the river. The greater portion of my big Tay salmon was bought by my friend the eminent salmon angler, M. Bass, Esq., M.P. I have often been asked 
what was the age of this fish. I calculate it must have been somewhere between twelve and fifteen years old. I have called this grand fish, "King of Scots."

\section{" THE SHANNON FISH."}

The fish killed with a fly in the Shannon by Mr. J. I. Phelps, October, 23, 1869, weighed 44lbs. (see Land and Water, No. 198), measured 4ft. $2 \frac{1}{2}$ in. in length, and 2ft. 4in. in circumference at the thickest part just above the dorsal fin.* This fish was going up the river near spawning time, and his milt was very large, whereas in our seventy-pounder the milt was small.

It might have been possible thät if Mr. Phelps' fish had spawned, gone down to sea, and come up again, he would have approached to the weight of our big Tay fish. I have stated in the Times that this fish probably went down to sea in February, 1868; my reasons for this statement are that I do not believe that a kelt of such gigantic frame as this fish must have been, would have had time to recover in condition and lay up, in the time intervening between February, 1869, and June, 1870 , the enormous store of fat which I found in his body. $I$ do not think that sufficient time is allowed by salmon observers for fish to recover their condition. Kelts hang about in fresh water-at least I know they do in the Spey for weeks and weeks, and will not take the sea water even when there is no obstruction between them and the sea. The physiological conditions of the kelt. are so different from that of a fresh-run fish, that I focl convinced the change from the one constitution of the body to the other must require considerable time, and Nature does not work in a hurry.

* A coloured cast of this fish is nor above that of the. seventy-pounder. 
In August, 1879, Mr. Towell of the Strand sent for me to examine a very large salmon from the Tay; it weighed 65lbs., and measured from the tip of the nose to the end of the tail along the curve of the body, $4 \mathrm{ft}$. $5 \frac{3}{4}$ in. ; the girth, $2 \mathrm{ft} .1 \frac{3}{4} \mathrm{in}$. During the last few weeks of the net fishery season of 1879 , there were an unusually large number of big salmon in the market: namely, one of $61 \frac{1}{2} \mathrm{lbs}$., from Mr. Dennis, of Messrs. Groves, Bond Street, and also four others weighing respectively 53lbs., 51lbs., 49lbs., and $46 \mathrm{lbs}$; this makes a total of $325 \frac{1}{2} \mathrm{lbs}$. for six salmon, viz. : no less than the weight of four sheep and a half (average sized sheep) as dressed for the butcher's shop.

Other casts of large salmon (Poissons celebres) are in my Museum of Economic Fish Culture, South Kensington.

\section{a large aton (hants) Salmon.}

On Friday, April 2, 1880, a magnificent salmon was caught in the run of the river Avon (Hants) at Christchurch. It weighed 53lbs., and measured $4 \mathrm{ft} .4 \frac{1}{2} \mathrm{in}$. in length, by $2 \frac{1}{2} \mathrm{ft}$. in girth, and was in most perfect condition. Mr. Tucker of Christchurch tells me that there is no record of any Christchurch salmon hitherto having been taken over 47lbs.; this fish I cast for Mr. Moss. I have also in my museum a cast painted by Mr. Searle, of a kelt salmon, $421 \mathrm{bs}$., also caught in the neighbouring river, Frome.

\section{"DLUE GOWN."}

Instead of going to the Derby in 1868, I stayed at home to cast this fish, for I hate racing and I love fish. While casting this fish the news arrived that the winner 
of the Derby was Blue Gown, therefore I called my big fish "Blue Gown."

I cannot say how exceedingly obliged I am to the fish merchants, not only in England but in Scotland, for their great kindness in letting me know of the arrival of remarkable fish, be they salmon or any other kind.

\section{ANATOMY OF THE SALMON.}

Anxious to learn something about the anatomy of the salmon, I took for the subject of dissection a fine specimen of a Rhine salmon. Of course I could not afford to buy the whole fish, so I only had the viscera.

The fish was four feet five inches long, twenty-seven inches in girth, and weighed 48 pounds. The scales were unusually large and prominent. Strange to say, I could not find any sea-lice upon it, and I have never yet seen one of these parasites on a Rhine fish. The milt was about the size of a common cedar pencil, and weighed (the two milts) half-an-ounce only. From these viscera I have made a very interesting preparation. Supporting the gills and gullet so as to make a funnelshaped opening, I poured plaster of Paris down into it. It was most interesting to see the stomach gradually extend as the plaster went downwards; it then gradually filled up the duodenum, the ileum, the pyloric appendages, and the lower gut. The whole preparation has since been dried, and exhibits many interesting points in the anatomy of the salmon. First, the œsophagal teeth ; these are situated at the entrance of the gullet, and are attached to one of the bones which support the gills ; there are nine œsophagal teeth on the right side, and five on the left, and they work against little islands of teeth on the opposite side of the œsophagus. The stomach (which is in fact nothing but a prolongation of 
the œsophagus) measures one foot two inches, and is of uniform circumference, nowhere more than four inches and one-eighth in circumference, and reminds one of a mop handle. The duodenum is six inches long; then come the pyloric appendages, which occupy the space of seven inches, and the lower gut, measuring one foot seven inches; so that the digestive organs of this fortyeight pound salmon, when extended their full length, measure three feet nine inches. There are no less than fifty pyloric appendages. Upon these appendages I found firmly adherent a dense mass of white fat; this weighed no less than five ounces, and goes strongly to strengthen my idea that one use of the pyloric appendages is to act as a storehouse for the fat which is gradually absorbed while the fish is in fresh water (see pp. 304-306). I have also discovered another very interesting fact about these appendages. Upon coming down to breakfast the next morning, I fancied I smelt a strong scent of violets in the room; I found it proceeded from the preparation of the salmon's viscera which were drying near the fire. The scent came from the pylorics only; it reminds me of the scent of a salmon fresh canght, and is not unlike the smell of new-mown hay with a dash of violet. Here, then, is a new fact which I am totally unable to explain.

The structure of the lower end of the gut is remarkable, inasmuch as the plaster within brings out very distinctly the fact that the internal mucous membrane is arranged after the manner of an Archimedes screw, admirably adapted to increase the extent of internal surface for the absorption of nutriment from the food during its passage through a tube containing within it a continuous spiral fold, coiled as to afford the greatest possible extent of surface in the smallest space. 
I fear that these anatomical facts may be uninteresting to some of my readers, and although the teleologists of the present day rather deny the doctrines of the "Bridgwater Treatises," and are slow at recognising the adaptation of structures and organs to the economy of the animals who possess them; yet $I$ think they cannot deny the fact that the structure of teeth, stomach, and intestines, have "some" relation to the food of the animal; and when I have time, I hope to enlarge considerably on this subject, the main object of course being to reason out the lessons derivable from the internal anatomy of the salmon as compared to that of other vertebrata, whether terrestrial or aquatic.

\section{FOOD OF SALMON.}

It may be asked what is the food of the salmon? I answer, sand-eels, shrimps, lug-worms, and fry of sea fish of all kinds. I think the one great fact in the natural history of the salmon (which I have learnt during my visits to Scotland), is the reason for the great abundance of salmon in that favoured country, viz., that the spawning grounds are of great extent, and the feeding grounds illimitable. From the Frith of Forth up to Nairn, I neither saw nor heard of a single oyster; the reason is that the east coast of Scotland is the land boundary of a vast submarine plateau of sand, and this sand abounds with the food of the Salmo salar : hence the abundance and fatness of Scotch salmon.

It is a law of Nature that the more space and better food animals have, the larger size they attain. Thus we find the biggest heads of deer in open and extended parts of the world, whether those ranges be in Canada for Wapiti, the Himalayas for Barasinga, as compared with heads of Scotch deer. The heads from the old 
German forests, or of fossil deer from the Thames bed, are large when placed alongside the heads from English parks and Scotch forests.

The same rule holds good with rivers, "The larger the river the bigger the fish," and the Tay and Rhine are about equal in their products of very large salmon. The reason of this, of course, is, that the big kelts, after spawning, do not so readily succumb to the diseases which usually kill them. In both instances the Rhine and the Tay are kept going with a perpetual flow of water from lakes. The kelts get washed down into the sea very soon after spawning, and therefore recover their condition quickly. Much also depends on the food of the kelts to make them grow. The estuary of the Tay is composed of, for the most part, sand, which sand contains an immense number of sand-eels and smelts. Feeding on these, the salmon quickly pick up in condition.

Cattle dealers know quite well what pasturage will feed up cattle quickly. Fatting ground for lean cattle is principally land which was once an estuary of a river. I give three examples of this. The beef of Norfolk is splendid, the animals having fed up well on the grasses growing on the alluvial soil of the neighbourhood. Splendid beasts can be seen from the railway between Yarmouth and Norwich. The Essex marshes also fat up cattle well; and as the express runs across the great Bridgwater flats, the passenger will see that the fatting grounds for the cattle of the west of England lie in this locality.

By the same rule, the fatting grounds for the salmon of the Tay and Rhine are of very first-class quality. Next to these come the salmon pasturages of the Severn. Those terribly destructive nets, the "hose nets," in Bridgwater Bay, that annually destroy myriads of the 
fry of sea-fish, tell us plainly of the vast quantities of salmon food that is bred in the great mud and sand flats which form the estuary of the Severn, and upon which not only the Severn, but also the Wye and the Usk "water sheep" pasture.

This big 64lbs. salmon from the Tay was sold at three shillings a pound. The total value, therefore, of the "beast" was $£ 912$ s., or about the cost of three ordinary sheep.

To bring sheep into a proper condition a certain amount of capital must be laid out for attendance, shelter, and food. The salmon requires nothing at all from the hands of men except to be protected at certain times of the year.

Thus it will be seen that "salmon farms" may be made quite as profitable, if not more so, than sheep farms, provided always the farmer knows his business; which, like many important matters, is often exceedingly simple, but requires constant care, special powers of observation, and, above all, the understanding of the unspoken language of the salmon themselves.

\section{POWER OF SMELL IN SALMON.}

Instinct, of course, has much to do in guiding salmon back to their own rivers, but, at the same time, I think that their power of smell is of great service to them in finding their way in the ocean. There is a part of the physical organism of a salmon which, I think, has not as yet been sufficiently noticed by those who study its habits, periods of migration, \&c. In many terrestriai animals the organs of smell perform most important duties; why should these organs not be equally important in fishes? Upon the front part of the snout of the salmon will be scen on each side an opening, 
divided into two by means of a diaphragm of skin which runs across from side to side. This is the nostril, and a beautiful bit of mechanism it is. If the valve at its. entrance, formed by the skin (as above described), be removed with a knife or a pair of scissors, it will be seen that the bottom of the opening consists of a flooring of a delicate red substance. If the fish's head be then placed in water, the red substance will be seen to consist of numerous folds lying side by side, and all diverging from a common centre. These folds float about free in the water, and receive the impressions of the smell of the water by means of the delicate nervefibres which are spread out upon them. The fish has, in fact, a nose made for smelling in the water, not a nose for smelling in the air. A dog cannot smell in the water, and I am certain a fish could not smell in the air, as the folds of his smelling organism would clog together, just as his gill-fibres clog together when he is out of his native element.

In a large salmon, I find that the flooring of the nostril is as large as a big pea in section; there can, therefore, be no doubt whatever that the power of smell is very important to the beast himself, or it would not be so large. It has been objected to my argument that water has no smell-has it not? In hot weather town sewers and offensive water courses demand, in a language not to be misunderstood, the attention of the sanitary authorities. Water is, in fact, a great absorbent of stinks; and luckily it is so, as one great use of water is to clean things, and it keeps its cleaning properties for a long time, i.e., if the old proverb be true-

"'Tis the greatest blessing that God hath gecn, That dirty water will wash clean." 
We will now apply our theory of smell in the salmon to practice. Doubtless, to the fish, each river has its own smell; taste or flavour it has hitherto been called, but this, I think, is a wrong expression, as a salmon's tongue has hooks upon it and is not so sensitive as the tongue of land animals ; in fact, it is more an organ of prehension than of taste. When the salmon is coming in from the sea he smells about till he scents the water of his own river. This guides him in the right direction, and he has only to follow up the scent, in other words, to "follow his nose," to get up into fresh water, i.e., if he is in a travelling humour. Thus a salmon coming up from the sea into the Bristol Channel would get a smell of water meeting him. "I am a Wye salmon," he would say to himself. "This is not the Wye water : it's the wrong tap, it's the Usk. I must go a few miles further on," and he gets up steam again.

We may learn another useful lesson from the presence of the power of smell in a salmon. I feel more and more certain every day that purity of water is the principal element of a good salmon fishery; if, therefore, stinking water is allowed to go into the river, the fish will perceive the fact when he may be possibly miles down the river. A foxhound can smell the scent of a fox on the ground, even although the fox might have passed over the ground a considerable time before. We ourselves can smell weeds or turf burning in fields at a very great distance; just so the salmon may receive cognisance of a town sewer, or tar water, or the dirty water from sheep washing, for a long distance down the river. His instinct will teach him that there is danger ahead, and he is very likely to fall back again, and small blame to him. Net fisherman should take particular notice of this argument; it is of commercial interest to them. 
How very important, then, is it to keep pollutions out of salmon rivers; they may not be actually strong enough to poison or kill the fish, yet it is very likely they will deter many from ascending the river.

I think different fish must have different powers of smell ; thus gudgeon, roach, \&c., assemble at the mouths of drains-the largest I ever caught was in the drain that carries the abominations of the town of Winchester down into the river. Scavenger fish, therefore, I dare say, would not care much about stinking water, but the lordly salmon will not put in an appearance in localities where his regal nose is likely to be offended by unsavoury smells.

\section{UNCLEAN AND UNSEASONABLE SALMON.}

I find there is a great difficulty throughout the country in interpreting section 14 of the Act of 1861, which reads as follows :-

"No person shall do any of the following things; that is to say, -

"(1) Wilfully take any unclean or unseasonable salmon;

"(2) Buy, sell, or expose for sale, or have in his possession, any unclean or unseasonable salmon, or any part thereof."

I have, therefore, with a view of throwing some light on the question of unclean and unseasonable salmon, adopted the only means which are likely to be conclusive, namely, the anatomical dissection and examination of the viscera and physical condition of the salmon themselves. With this view I have examined and dissected the viscera of several hundred salmon, from all parts of England, Wales, and Scotland, at various seasons of the year. My conclusions are 
as follows: firstly, that the external colouring of the scales of a salmon is by no means invariably a safe guide to its real condition; secondly, that the appearance of the pyloric appendages are most valuable in the diagnosis; and, thirdly, that the actual state of the development of the ova or milt is a point to which the strictest attention should be paid.

In order fully to explain what follows, I must premise by the statement that a salmon is more a sea-water (or rather estuary) fish than a fresh-water or river fish. Although it occasionally, as we know, feeds in fresh water, yet the greatest part of its food is obtained in the sea.

I believe the salmon takes the fly of the angler for a shrimp. Any one who has observed the action of a salmon fly, as worked in the water by means of the rod, will see how very shrimp-like it is. A favourite bait for salmon at Galway, in Ireland, is a real shrimp; but, strange to say, the shrimps must be boiled, or the salmon will not touch them. Boiled prawns-which, by the way, will keep well in glycerine-are successfully used to catch salmon in Scotland and on the North Tyne; and salmon will often take a prawn when they will not look at an artificial fly.

The salmon, therefore, feeding in the sea, gradually accumulates quantities of fat. Upon the pylorics of a 481bs. Rhine fish I found no less than five ounces of fat. It is necessary that this fat should be deposited in some reservoir in the creature's body, from whence it. may be gradually absorbed during its sojourn in fresh water. A certain portion of the fat is, I find, deposited in the cellular tissue between the skin and the muscular system; but an admirable arrangement for the storing up of the main bulk of this winter food is found in the presence of the pyloric appendages: these are long, 
worm-like, fleshy ofishoots from the intestine, situated immediately below the true stomach. In the salmon there are forty-five to sixty-five pyloric appendages. Although they may be subservient in secreting a fluid connected with digestion, yet there can be no doubt in my mind (and I venture to claim this as a discovery of my own) that they act as a convenient depository for fat, even if this be not their principal function. Analogous cases may be found in the hump of the camel, in bears, marmots, \&c.

The process of developing the ova and milt is a great tax upon the system of the salmon; thus, in a Tweed fish (January 14, 1869) just ready to spawn, the ova in weight amounted to a little over one-fifth of the entire weight of the fish itself ; and in a Tay fish (December $11,1868)$ the weight of the eggs amounted to a little over one-quarter the weight of the entire fish. The oily matter in the eggs and milt of a salmon is very great. I believe it, therefore, sound physiology to say that the use of the fat stored up in the pyloric appendages and under the skin is : first, to supply nutrition to the fish during its sojourn in fresh water; and, second, to afford materials for the development of the milt and ova.

The blocks, which I have caused to be engraved, will illustrate what I have endeavoured to explain above:- $\alpha$, the œsophagus ; $i$, the intestines ; $p$, the pylorics ; $m$, the milt. In the case of the "clean run" salmon the pylorics can hardly be distinguished, on account of the mass of fat which envelopes them, while it will be remarked that the milt is very small. This specimen is from a clean "fresh-run" salmon from the Avon, Hants; it weighed 35lbs., and was caught March 14, 1871. It was, in fact, an " up" fish. 
The other block represents the same structures from a "spawning" fish; they were taken from a $131 \mathrm{lb.}$ salmon, which was caught on the 19th January, 1871. It will here be seen that the fat has now entirely been absorbed from the pyloric appendages, while the milt is

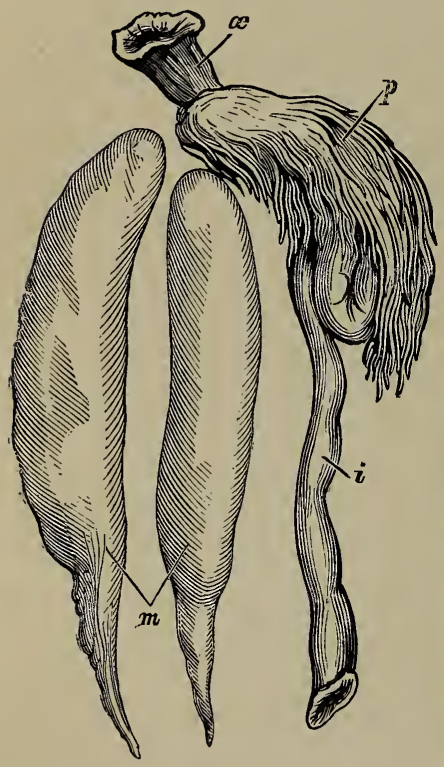

MILT AND PYLORICS OF AN UNCLEAN" SALMON.

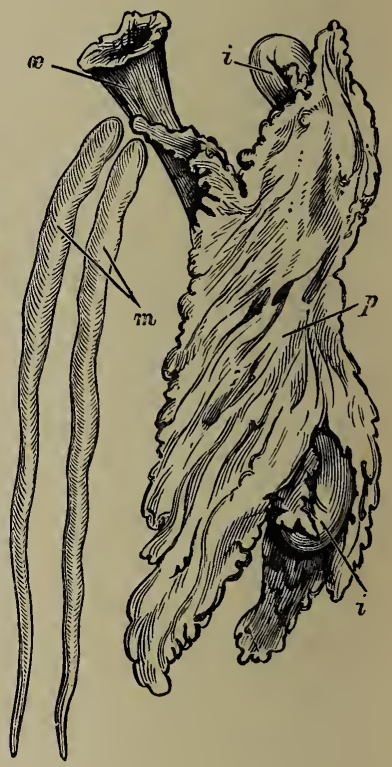

MILT AND PYLORICS OF A "ClEan rUN" SaLmon.

very large, the fish having been taken on or near the spawning-beds. Spawning operations being over, the fish would at once descend as a kelt or unclean fish to the sea to get on his pylorics a fresh store of fat. 


\section{SPRING OR EARLY-RUN SALMION}

Are a class of up-running salmon, the natural history of which has hitherto been a great puzzle to all observers. I mean the clean-scaled, well-developed, fat fish, that run up some rivers in the months of February and March; and I believe that if some of our large rivers were fairly tested, this class of fish would be found to be present even as early as December and January. The large Dutch fish which come to the London markets are good examples of these early fish; so early as the end of November every year, fresh-run fine fish, from 50lbs. in weight downwards, are to be seen in the London fishmongers' shops, and they continue to be sent for many weeks. Casts of the milt and ova of many of these fish are in my museum, and they form curious contrasts, as regards size and development, to the milts and roes of English fish at the same period of the year.

In England these fresh-run fish are caught in February and March, and in their upward progress they cross the paths of the great majority of their brethren who are coming down as kelts.

I have heard of an instance where, at one haul of the net in the tideway, a fisherman caught a female salmon full of ova, secondly, a fresh-run fish, and, thirdly, a kelt. My explanation of this fact is, that the female fish was a very late spawner, that the fresh-run fish was a specimen of the class I am about to describe, and that the kelt was going down stream in the proper course of things.

Having examined the anatomical conditions of several of these clean-run spring fish, and at the same time carefully considered this most difficult subject in 
all its bearings, I now venture to propose a solution to the question.

These clean-run fish are a Secondary Migration of salmon-a spring migration, in contradistinction to an autumn migration. I have shown above that the amount of fat upon the pyloric appendages will be a safe guide to ascertain the real history, travels, and position of a given fish. I therefore apply it as a key to help to unlock the mystery of the spring fish.

These clean-run fish, therefore, in my opinion, are those who have laid up a sufficient amount of fat during the time they have remained in the sea (dating from the kelt stage) to last them during their stay in fresh water; and I fancy (although I have no direct grounds as yet to prove it) that they are the early kelts of the previous year, who having reached the sea, say in January, 1868 , now reappear as clean-run fish in February, 1869, or, may be, even as very large fresh-run fish in 1870 ; much, however, depends upon the quantity and quality of food they find in the estuary; there are, I understand, enormous numbers of smelts in the estuaries of the Dutch rivers, and the food afforded by these, combined with other causes, goes a long way to make the Rhine fish lay up its stock of fat quickly, and therefore renders it ready to proceed all the earlier on its upward pilgrimage. I believe large numbers of smelts are also found in the estuary of the Tay. The early fish, therefore, having laid up a sufficient quantity of fat for their inland sojourn, do not wait till the descent of the autumn floods; but they avail themselves of the spring floods, being tempted by the state of the temperature and the great body of descending water, which informs them their road is clear, and also by the non-necessity of their remaining longer in the sea. This theory, I think, may 
be strengthened by the fact that the fat upon the pyloric appendages of most of the "fresh-run "British fish which I have examined is not nearly so abundant as on those of the fresh fish later in the season; these very fish, if there had been no floods in the spring, would probably have remained in the sea, and would have appeared in the river either in the first floods in July or August, or if there were no floods in these months, they would have come up in November and December as the large fish, which (as experience shows) are generally the latest to come into the river, and which, for the most part, spawn in the lower portions of the river.

These fresh-run fish, which form the " secondary migration," are certainly not, as some suppose, barren fish ; they will, I believe, spawn in the following winter : thus a fish ascending the river in the month of February, 1880, will, if not caught, deposit her eggs about Christmas, 1880, or even earlier. These fish do not, as a rule, come in large numbers; they are caught here and there singly.

Both to the angler and the owners of commercial fisheries they are of great importance,- to the one as affording excellent sport, and to the other as fetching large prices in the market. It becomes, therefore, a problem of the greatest importance, severely taxing the resources of science, to multiply their number.

\section{CATHEDRALS AND SALMON.}

Among the many facts that have come under my observation during my official journeys in the inspection of salmon rivers, there is one that has struck me very forcibly, viz., that there is almost invariably a cathedral town or towns upon the chief of our salmon rivers. This is to my mind by no means a coincidence, but a 
fact which I now wish to bring forward to the notice of the public, as I do not think the idea has ever yet been worked out.

I find that at the present moment there are in England twenty-five Bishoprics and two Archbishopries. I will now proceed to state the rivers upon which the various cathedral towns are situated. The See of York (founded A.D. 622) is situated upon the Ouse; Durham (founded about 1040) upon the Wear ; Exeter (founded A.D. 636), upon the Exe; St. Asaph (A.D. 560), on the Elwy; Hereford (A.D. 676), on the Wye; Llandaff (beginning 6th century), upon the Taff; Salisbury, on the Avon; Carlisle (A.D. 686), upon the Eden; Worcester (A.D. 680), upon the Severn ; Gloucester (A.D. 657), upon the Severn; Chester, upon the Dee; Ripon, upon the Ure: so that no less than twelve cathedral towns out of twenty-five are built upon rivers in which salmon are caught in more or less quantities at the present time.

The following cathedral towns stand upon rivers from which salmon have been exterminated:-Canterbury (founded A.D. 597), upon the Stour; London (1st Bishop Mellitus, 610), on the Thames ; Oxford (distinct Bishopric from Lincoln, 1545), on the Thames; Winchester (founded A.D. 634), on the Itchen; Bath (now with Wells) (founded A.D. 607), on the Avon; Rochester (founded A.D. 604), on the Medway. Six more cathedral towns may, therefore, be added to our list of cathedrals on salmon rivers, only that the fish have been exterminated from them by human agency. These agencies are as follows:-In the case of the Stour, mill weirs and pollutions; Thames, * weirs and pollutions ; Itchen, mill weirs; Avon, weirs and manufactories ; Medway, weirs.

* I trust, however, that the exertions we are making to restock this river will cause it to become a salmon river again in our time. 
It appears, therefore, that no less than eighteen bishops out of twenty-seven preside over dioceses that either do produce salmon, or ought to produce salmon.

The following cathedrals are built upon rivers that were never salmon rivers, and never will be, because they are not naturally adapted for that fish-viz., Lincoln, Norwich, Ely, and Peterborough; still, if there are no salmon, there is a good supply of fish of a coarser kind. St. David's, Chichester, and Bangor are near the sea-coast; and Lichfield, as far as I know, is not in a fish-producing country at all. Manchester, Liverpool, \&c., have been founded of late years only.

These facts, of the connection of cathedrals with salmon rivers, I think can be easily accounted for, inasmuch as when monasteries were first established, previous to cathedrals themselves being built, the founders selected sheltered localities where, for the most part, they could get a good water-carriage, and, at the same time, a plentiful supply of freshwater fish, especially salmon, for the use of the table on fast-days.

It sometimes, moreover, happens that in the neighbourhood of old abbeys we now find remains of the weirs which had been erected by the monks to "facilitate the catching of fish," and which, by the Salmon Act of 1861, would now properly be described as "fishing weirs"often, "fishing mill dams." This is especially the case on the Wye. Within a few hundred yards of Tintern Abbey can be seen a ripple in the river, indicating the existence of an old weir, which I was informed by $\mathrm{Mr}$. Alex. Miller, lessee of the fishery, was the remains of a fishing weir belonging to the monks of Tintern. I was anxious on entering Tintern Abbey to find other traces of salmon, and with this idea examined all the old tomb. stones. In the south aisle, about the fourth or fifth 
pillar from the doorway, I was much delighted to find there was an old tombstone, overgrown with moss, with the figure of a salmon cut deeply into the stone; it is not the figure of a fresh-run fish, but an old kelt, with a big beak. On the same tombstone there is a device of three salmon, with their tails interlocked together. I am sorry to say I could not make out the name of the person buried under this tombstone, and would feel most obliged if any antiquary would kindly help me. My friend, the Vicar of Whalley, near Clitheroe, in Lancashire, showed me his official seal ; it is three salmon twisted together, nearly the same as the device on the tombstone at Tintern. This device is also carved over the schoolhouse door. The vicar's house is close to the magnificent ruins of Whalley Abbey. As we are on the antiquities of salmon the following will possibly be interesting :-

\section{SALMON AND APPRENTICES.}

In nearly all the cathedral towns, as well as in many other parts of the country, I have heard the story of a clause being placed, in olden times, in the indentures of an apprentice, that "he should not be bound to eat salmon more than a certain number of days in the week." I am quite tired of hearing this story, and almost weary of hunting for an actual copy of an apprentice's indenture containing this clause. I once was very near getting it. Stopping to bait the horses at a little roadside inn near Exeter, the landlady told me this old, old, story; and, moreover, said she knew an old woman who had a copy of an indenture, only she lived "a bit off," and it was too far for her to walk to fetch it. I stopped the criver from taking the horses out of the carriage, and made "mine hostess" jump in, and drive instantly to 
the old woman's cottage. She was a long time gone, and $I$ hoped that she and the old woman were looking for the indenture. At last the messenger returned. "The old woman had burnt the papers last week;" so I must go on with my hunting for this precious document.

The idea generally prevails that this clause signifies great plenty of salmon available for food in the various rivers. I do not, by any means, put this interpretation on the story. My theory is that, in the spring months, the good folks used to go out and catch the kelts which come helpless and emaciated down the river after spawning operations.

Salmon in this condition are easily captured; many were, doubtless, as now, picked up dead in the river, and dreadfully nasty, tough, unwholesome food they invariably afford. Now, provident citizens who had apprentices to feed would buy large numbers of these kelts, salt them down, hang them up in a dry place to dry, and use them as food, upon which the unfortunate apprentices might be fed at a cheap rate for many months to come. A few dozen salted kelts were doubtless, in the eyes of the domestic economists of those days, a grand saving to the yearly bills, and quite good enough for apprentices; hence the protest to this kind of food on the part of these misused individuals.

In my Report for 1878 (dated 1879), I have given a general view of the salmon-bearing capabilities of all the rivers in England and Wales which my colleague, Mr. Spencer Walpole, and myself have to examine and report upon to the Home Secretary.

In my Report for 1879, dated 1880 (C 2587), I have made a catalogue of all the names I could ascertain, which are given to the various kinds of salmon in 
England and Wales, and also the names given to " the young of salmon;" to each name, whether adult or fry fish, there is a short description. Other results of my observations as to the structure, migration, and habits of the salmon are also given in this report.

Those interested in salmon should consult the last Report issued by Mr. Walpole, A. Young, and myself, October, 1880 (C 2660), on the "Disease which has recently prevailed among the Salmon in the Tweed, Eden, and other rivers in England and Scotland."

Mr. Walpole and myself have now published, as Inspectors of Fisheries, fourteen annual reports on the Salmon Fisheries. Since the Report for 1872, dated 1873 (C 725), these reports have been published in 8vo -a convenient and portable size; and the reports can be obtained through any bookseller from Eyre and Spottiswoode, Queen's Printers, East Harding Street, Fetter Lane.

\section{COMMON TROUT.}

(Salmo fario.)

German: Die Forelle; also-Wald Forelle, Stein Forelle, Schwarz Forelle, Gold Forelle, Teich Forelle. Bohemian: Pstruh. Danish: Bakorred. Norwegian: Kra Kro Kjo, Fjeldgoret. Swedish: Oerlax. French: La Truite.

Salmo fario deserves a volume to himself. One half of this volume might treat of his natural history, cultivation, habitat, structure, \&c.; the other half might be devoted to the noble science of fly-fishing.

I shall therefore content myself with giving the latest information I can about Trout, especially those of a remarkable size. In February, 1868, I received, through the kindness of Octavius Morgan, Esq., M.P., and the late Rev. Augustus Morgan, of Machen Rectory, New- 
port, Monmouth, a monster trout. The Rev. Mr. Morgan wrote:-

"Sir,-I have by this day's train sent you, as a New Year's gift, one of the finest specimens of river trout it has ever been my good fortune to meet with; you will see it is partly full of spawn. It was taken in the act of spawning on the gravel in the little stream which flows through the shrubberies at Alresford, after it has crossed the road by the water-dam leading from a large piece of water, the property of the Dowager Lady Rodney, and well known as 'The Alresford Pond,' adjoining the town of Alresford, Hants. It was said to have weighed, when first taken, 14lbs., but as it had evidently deposited a large portion of its spawn, it doubtless exceeded that weight previously to the operation. As this piece of water has no direct communication with the sea, I consider it to be a true specimen of the river trout.-Augustus Morgan."

I was indeed most grateful to Lady Rodney and the Rev. A. Morgan, for their kindness in allowing this marvellous fish to pass through my hands. It is a treasure that is not trove every day : a sort of "Wandering Jew," that comes once in a hundred years. With the greatest care, I handled this queen of trout; she weighed 14lbs. exactly. The measurements were-length, $30 \frac{1}{2} \mathrm{in}$; girth behind shoulders, $16 \frac{1}{2} \mathrm{in}$; middle of abdomen, 19in.; wrist of tail, $7 \frac{1}{2}$ in.; expanse of tail, $8 \frac{1}{2}$ in. I cleaned the slime off her great prize-pig-like back, and then cast her, and I am happy to say I never made a better model of a fish in my life. This model is now in my fish museum in South Kensington. I have heard of enormous trout being fatted for the table by Mr. Popham, 
of Littlecote, who used to send the late Duke of Wellington a brace of very large fish every year.

The old post-boy of the "White Hart," at Whitchurch, one "Bones," told me that he once tasted a piece of one of these trout that weighed 13lbs.

Lord Dorchester also wrote from Greywell Hill, Winchfield:- "A trout was taken in the mill-head here that weighed 14lbs. Not being in condition it was put below the mill, and thence stolen. It must have in flood-time come over a grate placed above the head to keep the jack from ascending. Our best fish feed upon a species of freshwater shrimp."

The trout in the Thames occasionally attain a very large size. My friend Mr. Forbes, of Chertsey, has a cast of a magnificent trout which he caught spinning at Chertsey weir. This cast, which I made, was afterwards painted by $\mathrm{Mr}$. Rolfe, and magnificently mounted in an appropriate case. This splendid fish weighed $161 \mathrm{bs}$.

On the 19th of April, 1880, a grand specimen of Thames trout was caught spinning by a local fisherman at Messrs. Ayres' wharf, Reading. The hon. sec. of the Reading Angling Association, Mr. A. C. Butler, kindly brought up the fish to me directly to cast. The weight was $16 \mathrm{lbs} .15 \mathrm{oz}$.

After the fish was cast it was conveyed to Windsor Castle and presented to Her Majesty through Sir Henry Ponsonby, Comptroller of the Household.

TROUT LICENSES.

I am glad to say that common trout are now being protected by Act of Parliament.

By the Freshwater Fisheries Act, 1878, the Board of Conservators is empowered to issue licenses for trout fishing. There many rivers and portions of rivers, or 
tributaries thereof, which do not afford good angling for salmon, but which, nevertheless, are well suited for the breeding and nurture of non-migratory trout. These trout streams when preserved will doubtless afford excellent angling for those who have not opporiunity of trying with the rod and line for the larger game fish, the salmon.

It is therefore very satisfactory to learn that so many anglers have taken out trout licenses. There have been issued during the season of 1879 :-

In the Severn, 4,000; Towy, 1,754; Usk, 1,746; Fowey, 570; Dart, 398; Teign, 324; Cleddy, 238; Rhymney, 73.

Common trout are now plentiful in Australia and New Zealand, and I believe I may fairly say that these colonies owe the existence and almost abundance of trout at the Antipodes to myself. In Jan., 1864, when my friend Mr. Youl was packing salmon eggs in the ice on board the ship Norfolk, I asked him to allow me to pack a box of common trout eggs in the ice among the salmon boxes. Mr. Youl now often laughingly remarks, "I was then nearly pitching them overboard into the dirty water of the docks." Luckily he did not do so, as I have every reason to believe that the trout born from these very eggs are the origin of all the trout now in New Zealand and Australia. I was only able to supply the ova (from twelve to fifteen hundred) of one pair of fish. I caught the fish myself, after a very careful arrangement of the nets (for the fish were very shy), in a branch of the Itchen which runs through the garden of Admiral Keppel, at Bishopstoke, near Winchester.

Mr. Francis Francis at the same time sent Mr. Youl some eggs; these were, I believe, those of the Bouge 
or migratory sea-trout, and of the common trout from Hungerford. At all events, trout now exist at the Antipodes-the greatest feat of Pisciculture of modern times, and entirely due to the energy and perseverance of my friend Mr. Youl. Whether it will be possible to establish salmon at the Antipodes is as yet an open question. The difficulty is to prevent the destruction of the fry by their numerous enemies when they descend to the sea. The common trout, not being migratory, have not this perilous gauntlet to run.

Although the introduction of trout into Australia has proved such a great success, and in some sense is almost as important to the colonies as the introduction of sheep (and I have had great difficulty in finding out who first introduced sheep into Australia), yet neither Mr. Francis nor myself have as yet received any public acknowledgment except that printed below.

Being sure that in a few years it will be forgotten by the Australians who it was first sent over trout eggs from England, my friend Dr. Stirling brought the subject before the Melbourne Government, and in September, 1879, I received the following:

“ Chief Secretary's Office, Melbourne, "June 16, 1879.

"The successful acclimatization of the English trout in the streams of the colony having been now thoroughly established, I think the time has arrived when it should be placed on official record that the honour of initiating such acclimatization in Australia is certainly due in the largest degree to yourself and Mr. Francis Francis, who jointly presented to the Tasmanian Government the boxes of trout ova in 1864, for the purpose of introducing that fish into Tasmanian Waters. 
The feasibility of their acclimatization having been proved, a supply was thence obtained at a later period for this colony, and some of its rivers may be said to be now fairly stocked.

"The aid you thus gave in demonstrating the practicability of conveying the fish indigenous to one hemisphere to another, and thus establishing a supply for the inhabitants of the latter of food and sport, is one of such eminent practical utility, that it gives me the greatest pleasure to be instrumental in conveying to you the deep sense of the obligation under which you have placed this colony by your thoughtful donation fifteen years ago.

"Frank Buckland, Esq."

"Bryan O'LoghLen.

The authorities of New Zealand have most generously sent me a silver claret jug, with the following inscription :-

"To Frank Buckland, M.A., M.R.C.S. (late 2nd Life Guards), Her Majesty's Inspector of Salmon Fisheries.

"From the Superintendent and Provincial Council of the Province of Otago, New Zealand, in acknowledgment of the able and valuable services most kindly rendered by him on the occasion of the first transmission of salmon ova to the province in January, 1868."

Those who are interested in sending salmon and trout to the Antipodes will find the whole story most admirably recorded in a book entitled, "Salmon and the Antipodes; being an Account of the Successful Introduction of Salmon and Trout into Australian waters." By 
Sir Samuel Wilson. Published by Edward Stanford, 55, Charing Cross, London, 1879.

\section{BULL TROUT.}

\section{(Salmo eroix.)}

Local names: Grey Trout, Round-tail, Coquet Bull Trout of the Tyne, Scurf of the Tees. Welsh: Brech-y-dail, or "Fall of the leaf." German: Meerforelle. French: Trinte de IIer.

The Bull Trout is most abundant in the rivers on the north-east coast of England, more especially in the Coquet, Tweed, Tyne, Tees, and Wear.

The bull trout is certainly greatly inferior in flavour to the salmon, his flesh being white and comparatively tasteless. In the Newcastle market it is worth some: threepence a pound less than the salmon proper.

I am told that the fishwives occasionally clip the round tail of the bull trout quite square, and sell it for true salmon. French people seem to prefer bull trout to salmon.

The Paris markets will take any number of bull trout, especially at the back end of the year, and afterthe English close time commences.

Hard facts and diligent observation, carried on for a series of years, especially by my friend Mr. W. R. Pape, lessee of the Dulke of Northumberland's fisheries. at Warkworth on the Coquet, proved indubitably that. the best run of bull trout is late in the year, when the nets are off; the same thing happens yearly on the: Tweed and on the Tyne, and the consequence is that. in these rivers, I am sorry to say, the bull trout have, and still are obtaining, much too great a pre-eminence. over the salmon proper. In my late official reports, I 
have gone most fully into this very important question, and feel convinced that the time is not far distant when serious steps must be taken to counteract the great predominance of bull trout. This must be done by lengthening the netting season, allowing "splash nets" at the mouths of the rivers, especially of the Tyne; and by altering the mesh of nets at certain seasons, all of which matters must be left to the consideration of local Boards of Conservators, subject to the approval of the Home Office.

The superabundance of bull trout in the Tweed is, in my opinion, one of the great causes of the salmon disease in that river. See Official Report on the Salmon Disease, September, 1880.

\section{GILLAROO TROUT.}

(Salmo stomatichus.)

THIS trout is remarkable as having a stomach so thick and firm that it has been by some called a gizzard. I have some fine specimens of these stomachs taken from Gillaroo trout, caught by my friend Mr. T. R. Sachs, in Lough Derg, Ireland.

The great anatomist, John Hunter, examined into this curious form of stomach. He did not consider it a true gizzard, but simply a thickened stomach, endued with sufficient strength to break the shells upon which it lives. It has no grinding powers like the gizzard of a bird, say a chicken. This curious stomach of the Gillaroo trout is most worthy of attention on the part of anatomists and physiologists, and it remains to be seen by experiment whether or not the stomach of the Gillaroo trout would or would not alter if the character of the food was changed. 


\section{THE SEWEN. \\ (Salmo Cambricus.)}

The Sewen is simply a local variety of the Sea-Trout, and called locally Salmo Cambricus. It is a Welsh fish, and well known in all the rivers of Wales, Devonshire, and Cornwall.

In certain of these rivers the mesh of net has been altered to a smaller size, in order to enable the fishermen to catch the sewens; which, being much smaller fish than the salmon, had hitherto escaped the larger salmon mesh, namely, two inches from knot to knot.

\section{SEA TROUT.}

(Salmo trutta.)

A common fish in most of our salmon rivers, distinct from the salmon and bull trout. It is the same as the white trout of Ireland, and the peal of Cornwall and Devonshire.

\section{THE GREAT LAKE TROUT.}

(Salmo ferox.)

THE Great Lake Trout is found in some Lochs in Argyleshire, and also Loch Rannoch, and Loch Ericht, also in Loch Shin and Assynt in Sutherlandshire; for further particulars I would refer to that excellent book, "The Angler's Guide to the Rivers and Lochs of Scotland." By Mr. Thomas Tod Stoddart.

\section{LOCH LEVEN TROUT.}

(Salmo leveneusés.)

Tuis excellent and beautiful fish is found only in Loch Leven, and gives excellent sport to anglers. Not only 
are the fish in Loch Leven most carefully protected, but large numbers are bred artificially and turned down by Sir James Ramsay Maitland, of Craigend, Stirling, who in October, 1879, had 12,000 of these fish in ponds to be turned out when the proper time arrived. These were hatched in 1875-6-7, and weighed from half-a-pound to five pounds.

\section{CHARR.}

Public attention having been called to the great destruction of a valuable indigenous fish which has been going on from time immemorial in the Lake district, namely, the charr, in February, 1878, my colleague, Mr. Walpole, and myself were instructed by the Home Secretary to institute an inquiry into the whole matter, and in that year we presented to Parliament our Report on the English Lake district.*

As our report has probably not been generally accessible, I now give an abstract of the valuable evidence which was given to us. S. H. Jackson, Esq., the clerk to the Eden Board of Conservators, stated-

"The area of the English lakes is 35,420 acres. The Lake district may be said to be bounded by the Lancashire and Carlisle Railway from Carnforth to Penrith; by the high road from Penrith to Workington; by the Derwent from Workington to the sea; and by the sea shore from the mouth of the Derwent to Carnforth.

"The produce of these lakes, excepting Windermere, is small, both as to food and sport.

"Windermere is very productive, but very hard netted, and the fish are decreasing in size.

"In Coniston the fish have been poisoned by mines.

* Eyre and Spottiswoode, Printers to the Queen (c. 2004). Price 2d. 1878. 
The mining industry is now very much reduced. Coniston contains about 3,000 acres of water, and ought to be very productive."

Mr. John Fell, chairman of the Kent Board of Conservators, stated-

"The lakes and tarns, Windermere, Coniston, Esthwaite, Grasmere, and Rydal-Esthwaite and Grasmere are too shallow for charr-are in the Kent district.

"The close season for trout and charr should be from the 20th October to the 28th February inclusive."

Other witnesses stated-

"In Windermere the charr are in the deep water, the trout on the shingly and rocky shores, the pike and perch in the weedy bays and about the shallow rocks in the middle of the lake.

"The charr spawn at two different times in the river Brathay, and at about ten places by the shore of the lake. The trout spawn in the river Rothay. There are two sets of charr, one spawning now (February), the other in the autumn. Believes that all charr that have not spawned are bright, and that after spawning they are red bellied. The larger charr are not red bellied all the year. The charr go up the Brathay on the 13th October-Ambleside sheep fair."

A writer in Land and Water states: "Charr run out of Windermere to spawn in the Brathay. Although two. rivers fall into Windermere at its head, forming a junction above the lake, the charr never go up the Rothay, they turn off at the fork into the Brathay-the. reason for this has never been explained.

"Some charr spawn in November, some in February. The trout spawn in Consey, Troutbeck, and Rothay. The Brathay is almost entirely occupied by charr. 
CULTIVATION OF TROUT AND CHARR IN THE LAKES. 325

The charr come on to the banks at the end of October. The red charr are sparvning now (February). The 14th of February is the height of the spawning season for red charr. The close season for them must extend to the 1st of March.

"The net fisheries of Windermere are divided into three cubbles (cobles), and there are twelve fisheries. The fisheries in each cubble are common to the different proprietors, except the charr rights, which are clearly set out.

"A skelly, near Carlisle, means a chub ; in Ullswater it means a freshwater herring.

"The largest charr he ever saw was 2lbs. in weight; an average charr is from a $\frac{1}{4} l b$. to $\frac{1}{2} 1 \mathrm{l}$."

The following are the conclusions at which Mr. Walpole and myself arrived. We reported to Mr. Cross as follows :-

"We recommend therefore:-

"1. That the provisions of the Salmon Fishery Acts, 1861 to 1876 , relating to trout and charr, should be extended to the entire English Lake district, i.e., to the counties of Cumberland and Westmoreland, and to that part of Lancashire which is situated to the north-west of Morecambe Bay.

"2. That within these limits it should be illegal to fish for trout and charr between the 2nd day of October and the 28th day of February, both inclusive; but that the conservators of any fishery district situate within such limits should have power to alter this close season for trout and charr (not trout only) with the approval of the Secretary of State.

"3. That within the limits it should be illegal to use a net having a mesh of___ \&c., \&c. 
By the Freshwater Fisheries Acts, 41 and 42 Vict., cap. 39 , it is illegal-

"1. To fish for, catch, or attempt to catch or kill, trout or charr during the close season between 2nd October and 1st February following, or during any close season which by bye-law may be substituted for the same.

"Nоте.- - It is already illegal to buy, sell, or expose for sale, or have in possession for sale, trout or charr, between 2nd October and 1st of February following (36 and 37 Vict., c. 71 , s. 20)."

An abstract of the Freshwater Fisheries Act, which the Home Office has widely circulated, is found on p. 376 of this book.

\section{POLLAN.}

(Coregonus pollan.)

German: Die Bodenrenke, Sandfelchen, Blaüling.

Aт a meeting of the Manchester Angling Association held in March, 1879, an interesting paper was read by Dr. Simpson on a comparison between the Pollan of Ireland and the Grayling, of which the following is an abstract: "In the spring of the year there are usually in the market a large number of bright silvery fish which the fishmongers call grayling, or freshwater herrings. These are principally taken from Lough Neagh, in Ireland, and known there as pollan. These fish bear a strong likeness to the grayling, but there are many points of difference. First, the scales of the pollan have not the glistening nacreous sheen of the grayling, being browner, as if sprinkled over with dust. Second, the pattern formed by the coalescing of the adjoining scales is different in the two, and the line 
along the side is more distinct in the grayling than in the pollan. Thirdly, the pollan has not the pear or lozenge-shaped eye of the grayling, nor the large and very remarkable fin which distinguishes the grayling. Both possess the adipose fin; the grayling belongs to the genus Salmo, the other to the Coregonus. The pollan does not take a bait."

This fish is also found in Loughs Erne, Derg, and Corrib.

In the spring of the year pollan are often mistaken for young salmon, and have been reported to $\mathrm{Mr}$. Walpole and myself as such.

I am told they are found in most of the lakes of Austria and Bavaria.

\section{POWAN.}

(Coregonus fera. Coregonus acronius.)

Local names: Freshwater Herring, German: Der Kilch, Das Kropffelchen, Sandffelchen. French: La Gravenche.

THIs fish is found in the Lake Constance and other lakes of Southern Germany and Switzerland.

It is also found in Loch Lomond, the fishery lasting from March to September. They are considered best in August and September. The consumption of these fish is very local.

\section{THE GWYNIAD.}

(Salmo Wartmanni. Coregonus clupeoides.)

German: Die Renke, Das Blaufelchen. French: La Lavaret. Swedish : $S i k$.

Tris fish inhabits the lakes of Switzerland, Austria, and Bavaria.

In Land and Water, No. 13, April 21, 1866, is an able paper by J. H. C. on the Gwyniad. 
The only place where it is found in this country is Bala Lake and Lynn Tegid in Wales.

The gwyniad resembles the common trout in shape, but is thicker in proportion; his length, ten to twelve inches; head, small and very taper; the upper lip extends considerably beyond the lower, so that the mouth appears placed beneath; the general colour is a silvery grey, the scales large, the base of each scale marked with a dusky speck; the fins are pale brown.

The gwyniad is not found in Windermere, or any fish at all resembling it. There is a fish found at Ullswater and its tributaries, known by the name of the Skelly, which bears a considerable resemblance. His skin is almost of a pearly whiteness.

\section{THE VENDACE.}

(Coregonus albula. Coregonus Willughbii.)

German: Die Kleine Maräne. French : La petite Maraene, Marenken. Danish : Mariner. Norwegian: Laagsild. Swedish : Sikiöja.

Turs fish is found in the lakes of Germany, Western Prussia, Poland, and Pomerania.

There is only one place in Scotland, I believe, where this fish is found, and that is Loch Maben, Dumfriesshire. It is said to have been imported here by Mary Queen of Scots.

The family of Coregonus are exceedingly puzzling.

Mons. de la Blanchère, in his "Dictionnaire des Pêches," writes: "After a special study made at the imperial establishment at Hunnique, where. I have had fishes of all ages under my eyes, I have arrived at this conclusion: one of two things, either the genus Coregonus 
ought to be composed of a dozen species, distinct, but based on characters which are fugitive and little marked; or there is but one species, which is endowed with great variability. This is not without precedent among the inhabitants of the water."

Sufficient attention has not yet been given by the proprietors and fishermen living in the Lake district to the diagnosis of the various species of charr.

I would recommend those who wish to study this subject to study a series of papers written by Dr. Günther, of the British Museum, published in the proceedings of the Zoological Society of London for the years 1862, 1863 , and 1865.

Dr. Günther sums up the result of his investigations with respect to the British charr as follows. He shows that

(1) Three very distinct species of charr are found in Great Britain, namely: S. Willughbii, in the Lake of Windermere and in Loch Bruiach; S. Perisii, in Wales; and S. Alpinus, in certain parts of Scotland.

(2) That those three species differ by most constant characters from the S. Umbla and S. Salvelinus of the Continent; but that S. Alpinus in Scotland is closely related to S. Alpinus of Iapland, differing merely by its smaller size when first attaining to maturity, and by the number of vertebræ, there being sixty-two in the Scandinavian variety and fifty-nine in the Scottish.

(3) That Iceland is inhabited by a distinct speciesS. Nivalis.

(4) That the charr of Ireland form a separate group by themselves, distinguished by the feeble development of their dentition; and that the charr of Lough Melvin (S. Grayi) is a distinct species from that of Lough Eoke and Lough Dan (S. Colii). 
To those who cannot get specimens of the charr themselves $I$ have the greatest pleasure in recommending a most beautifully illustrated book, "British Freshwater Fishes," by the Rev. W. Houghton. Illustrated by a coloured figure of each species drawn from nature. (W. Mackenzie, 69, Ludgate Hill, E.C.) Most of the charr family in this book are beautifully figured.

\section{THE GRAYLING, OR UMBER.}

(Salmo thymallus. Coregonus thymallus. Thymallus vexillifer:)

German: Die Aesche. Der Asch. Polish: Lipien. Danish :

Stalling. French : L'ombre commune. Norwegian: Harren.

Swedish: Harr.

IN the Fishing Gazette, No. 127, Sept. 27, 1879, Mr. W. H. Bullock has published some admirable chapters on the habits, homes, food, and modes of capture of the Grayling. With his permission I will now give an abstract of these valuable papers.

"The queenly Grayling worthily occupies the place of honour vacated by the trout for the months of September, October, November, and December; that is to say, angling for grayling is best during these months. His name, Thymallus, is derived from the word thyme, the grayling having a somewhat thyme-like smell. He thrives best in streams where there is a happy mixture of deep holes and scours, and where the bed is composed of marl, granite, gravel, and no mud. When he rises at the fly he ascends like an arrow in the air. They do not rise well until October comes in and after there has been some sharp frosts. 'The graylings' paradise is in the rivers of Shropshire, Herefordshire, Derbyshire, Hampshire, Yorkshire, and Wiltshire. The 
very best stream in the world for grayling is the Teme, and Lintwardine is the choicest spot of all."

In the south of England the best rivers are the Test, Avon, and Itchen. In the north, the Wharfe, Derwent, Wye, and Dove. The Dee contains a few in its upper waters. The food of the grayling consists of all kinds of flies, and the Mayfly is the special favourite. The grasshopper is also a great bait for him; gentles, worms, insects, and grubs of all kinds, especially wasp and cabbage grubs, are all used, and, as a rule, this fish takes his bait when in motion. Mr. Bullock, in his subsequent chapters, gives some valuable hints as to grayling fishing, which are quite worthy of being reproduced in a different form.

Grayling were introduced into the Glasgow Clyde in quite recent years. I understand that there is a large. space of water in the Clyde which is open to anglers. The best grayling water in the Clyde is about Lamington-a mile or two above, or a few miles below. I have: this upon the authority of Mr. W. Haig, 16, Hanover Street, Glasgow.

The introduction of grayling into trout rivers should not be undertaken without due consideration. Grayling, I have observed in my museum at South Kensington, are great bullies, and are continually hunting the trout about.

\section{SMELTS, OR SPARLINGS.}

\section{(Osmerus eperlanus.)}

German : Der Stint. Hanoverian: Spierling. Danish: Smelt. Norwegian : Slommen. Swedish: Nors Slom. Dutch: Du Spiering. French : L'Eperlan.

A VERY favourite dish on the London dinner-tables is the Sparling or Smelt. There are smelt fisheries at 
the following places : Boston (Lincolnshire), Brighton, Lynn, Norwich, Ulverstone. The smelts come along the Brighton coast about March. They are caught with seine nets. They do not stay long on the Brighton coast. The proper mesh for smelts at Brighton is about fifty meshes to the yard.

There is also a smelt fishery at Boston; the smelt fishing here commences in September and goes on till May. In September they get smaller and are of not much use. They are caught in the upper part of the estuary; the net is an ordinary seine, with wings and a cod end. There is one smelting boat at Boston, but there are three smelting boats at Lynn. The smelts at Boston are full of roe in the end of April.

At Ulverstone a considerable number of sparlings are caught. Mr. Jackson Lee of the Kent Salmon Board of Conservators informs us that in February the sparlings are heavy with spawn ; they begin spawning about the middle of March, and the spawning is all over by the middle of April. They come up into the bay in early autumn, and follow the way of the salmon.

Much valuable information as to the habits and food of smelts, kindly given me by Mr. Wanking of Ulverstone, will be found in my appendix to the "Sea Fisheries Ricport, 1879," p. 201.

There is a sparling fishery in the estuaries of many of the rivers running into the Solway, especially at Wigtown Bay and the mouth of the Nith. They come up in March and April to spawn; they are very small in June and July. From the end of July to the end of August they get larger. In September they are at their prime. Sparlings spawn at the head of the tideway; they never go further up the river than the brackish water. They assemble in considerable quantities at the head of 
the tideway near Norwich, and I hope in the course of next spring to be able to make some experiments in hatching their eggs artifically. The eggs are of a yellowish colour, but smaller than salmon eggs.

\section{ARGENTINE.}

(Scopelus borealis. Scopelus Pennantii.)

THIs fish appears to be limited to the northern portion of the Atlantic. No instance is recorded of its ap-

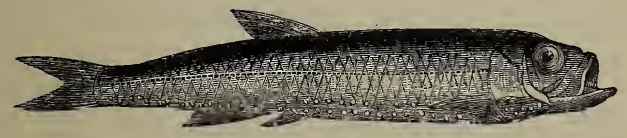

ARGENTINE.

pearance on the coasts of Devon or Cornwall. It has been obtained in the Orkneys, Wick (Sutherlandshire), and Banff. They are generally found in the cold months of the year thrown ashore, entangled by seaweed in stormy weather. It is a very small fish, measuring about two inches in length, and half an inch at its greatest depth. There is an able paper on the argentine by D. W. B. Clarke, in the Magazine of Natural History, p. 32, January, 1838. 


\section{ON THE CULTIVATION OF FISH-PONDS.}

There are hundreds of acres of lakes and ponds about in this country which might be readily made to grow fish, if the owners of these waters only knew what to do and how to do it.

To many manor houses, and to almost all the ruins of monasteries of England, fish-ponds were formerly attached-in most instances they might be brought into work again. The obvious use of these ponds was to supply fish to the monks and others during fast days, for it must be recollected that sea fish could seldom, at this period of English history (owing to the slowness of conveyance and the ignorance of the preservative qualities of ice), be transported from the coast so as to be in fit state for the table on arrival at inland localities.

The monks of old knew a great deal about the cultivation of fish-ponds, and I am informed that this pond cultivation is still carried on to a great extent in Western, Central, and Southern Europe; in fact, in the very localities where the same conditions of things which formerly prevailed in England-viz., fast days and no sea fish-are still to be found.

There is a special treatise on the cultivation of fishponds, written by an Austrian bishop. It is printed in I.atin, and with a black letter, and is a very rare book. 
There is a copy in the Bodleian Library at Oxford. The title is "Dubravius de Piscinis." For many years I kept a sharp look out for this book, and was at last fortunate enough to buy one at a bookstall for eighteenpence; it is a little book, six inches by four inches. It is beautifully printed, and the ink blacker than any inks used now. The date of it is 1559 , therefore it was published 321 years ago, in the second year of the reign of Queen Elizabeth. This is a copy of the title-page: "Jani Dubravii qui postea Olomucensis Episcopus creatus est De Piscinis et Piscibus qui in eis aluntur, naturis libri quinque, vi doctissimi, ita ad rem familiarem augendam utilissimi, ad illustrem virum Antonium Fuggerum. 1559."

Dubravius was a high church dignitary, Bishop of Olmutz in Moravia. Bishop or no bishop, he knew more about fish-ponds than we do at the present day.

After him came another writer on fish-ponds, to wit, John Taverner, gentleman, who in 1600 (the 42nd year of the reign of Queen Elizabeth) published a companion treatise, of which the following is the title: "Certaine Experiments concerning Fish and Fruite practised by John Taverner, and by him published for the benefit of others." (Small 4to. London: printed for William Ponsonby, 1600 . $38 \mathrm{pp}$.) This tract is in black letter, and a very rare book.

The following is an abstract of the advice Dubravius gives us as to the cultivation of fish-ponds:-

"Experience has shown that the proper treatment of fish-ponds is to alternate a crop of fish with a crop of vegetables.

"Each pond should be so arranged that it can run perfectly dry at will.

"We will suppose three ponds to be in existence- 
"1. Let the water be run off from pond a completely, and as it empties catch the fish and place them in pond $\mathrm{B}$.

“2. Having let a run completely dry, plant the mud with oats, barley, cabbages, or rye grass. The crops laving been in due time reaped, re-fill it in the winter and stock it with fry.

" "3. Then dry and plant в. At the same time dispose of all the larger marketable fish, and put the half and three-parts-grown fish into pond $\mathrm{c}$, which now for the first time is taken into the regular round of cultivation. Thus with three ponds worked upon this system the proprietor will always have a crop of vegetables growing in one pond, yearling fry in another pond, and breeders, with the fish fattening for the market in the third."

I feel convinced that this system should have a good trial in England, for thus the heavy and expensive work of clearing out or, as it is called, mudding ponds, would be entirely obviated, and a pond might be set to work, first to grow a crop of vegetables and then a crop of fish. If ponds are not emptied for some time, fish will not thrive in them, or rather they come to a standstill both in number and size, while the stock altogether deteriorates. If a pond, however, as I know from experience, be left dry, even without planting, for a year or more, the fish turned into it will grow and fatten in a most extraordinary manner. The reason, probably, is that the ground is sweetened and the food becomes abundant.

One hundred and sixty-seven years ago, namely in 1713, the eleventh year of the reign of Queen Anne, was published another excellent book on fish-ponds, the original edition of which, through the kindness of 
my friend Mr. George Rooper, I have been able to examine; here is the title, "A Discourse of Fish and Fish-ponds. By the Honourable Roger North, Sept. 14, 1713." His advice is to the following effect: "In October draw the sluice and dry the pond. As the pond falls catch the fish by degrees, cut channels to keep off the land water. When your pond is dry, keep it so all the summer, and you may make a profit of the soil by ploughing or feeding.

"The following Michaelmas, or a little sooner, turn in all the water you can that the pond may fill, and when it is nearly full it is ready to receive stock again. At the same time lay dry another pond, proceeding as before. This you may do alternately during your whole life.

"If you have but two ponds this is the best course, and will turn most to the profit and feed of the fish. You may let your ponds stand full two or three years, not longer, unless you delight to see starved lean fish. The oftener the ponds are laid dry, the better the feed of fish shall be."

Mr. North recommends that the mud should not be removed unless with great care, as the banks of the pond may thus be injured; he rather recommends instead to plant a crop of osiers in the mud; oats also will grow in the mud. He also advises that facilities should be afforded for cattle to come and drink and stand in the pond, "as it conduces much to the thrift of the cattle as well as the feed of the fish."

"Great waters should be dried and sowed with oats once in three, or at most four, years, and that at the end of January or the beginning of March. After Michaelmas following, you may put in a very great stock, and thin them in the following years as feed will decline." 
He then warns proprietors against overstocking their ponds, for fish bred in great numbers in bad waters, overstocked and almost starved, may in process of time degenerate, and both lose a good shape and be less apt to grow up to greatness than others that have been better descended of a cultivated stock; and, on the other side, it is possible that by coming into good quarters fish may improve and mend.

This is most important to breeders of carp, and the remedy of course is to net frequently, and to sort the fish.

"I have found a great analogy between the stocking waters with fish and pastures with cattle, and that the same conduct and discretion belongs to both. Waters may be overstocked, as pastures often are : so both may be understocked. The latter is the less error, for if you overstock you lose the whole summer's feed, if you understock you lose only the rest of your profit; what you do feed is much better, and turns to account by more ready sale. So also of beasts, some of the same age and feeding will not thrive so well as others." One thing is quite certain, that the more numerous the fish are the smaller they get. Nobody ever yet saw a fat charity boy. Charity boys and girls are generally about the same size, and run thin; the reason is, that they have just enough food to keep them in health, but not enough to make them fat-the guardians take good care of that.

The same rule that applies to charity children applies to fish. When the ponds are drained, a number of small fish that are from six to eight inches long are found, and this is what you are to do with them: "Of these bred fry you may put a hundred into four rods square of water, or near that proportion, these then 
can be fed up like chickens, and in time turn to great profit; because, a pond will, though but four acres, feed up 1,600 carp in two, and perhaps, one year, from ten to eighteen inches long, fit for your table, present, or sale."

As regards the number of fish that water will carry, Mr. North confesses he can lay down no actual rule; experience must be the guide in stocking the waters. $\mathrm{He}$, however, gives the following hints: "When laying the pond dry in every year, you must observe whether the fish be well fed or else thin and lean, and accordingly you judge whether the stock was too little or too much for the water."

In January, 1870, I received the following valuable information from a gentleman residing in Austria, who at the present time cultivates his fish-ponds. The water in the pond is drained off towards the end of October. In the ensuing spring the dry pond is ploughed up or harrowed for cropping like any other field; after this, beetroot or barley is sown. The latter crop (barley) is particularly good for fish.

Jirectly after harvest the pond is again filled with water, the fish put in, and allowed three, or at all events two, years. Care must be taken to stock the pond with such fish as the quality of the water and soil are found to suit.

If the bottom is too slimy the pond must be drained off, and the slime dug out in the winter.

This slime should be thrown into heaps and allowed to remain for a year, when it forms excellent manure.

My friend Captain Salvin, having read my observations on fish-ponds, kindly sent me the following valuable note:- "About the same time (namely, the reign of Queen Anne), when the Honourable Roger 
North, whom you have quoted, published his book, my great grandfather employed Kennedy, a noted landscape gardener, to lay out the grounds at Croxdale, in the county of Durham. In the garden itself there are three ponds. These ponds are fed by a stream, which is not allowed to run through them, but is let in by sluices at pleasure. The stream is conveyed by an artificial watercourse outside, which is clearly a wise precaution against their filling up with sediment during floods, thus preventing an awful amount of trouble and expense hereafter. No. 1 is a small pond used as a stew, in which fat fish are kept which are ready for the table and which have been netted from Nos. 2 and 3 , or from the many other ponds on the property. It is in this stew that there is a capital contrivance for taking out the fish which I have not met with elsewhere, and which I will try to describe. The deepest part of this little pond is at the sluice, where it is emptied into No. 2, near which is a strong square wooden box, say four feet deep by five square, and this is sunk flush with the bottom of the pond, having two posts let in on each side at the middle of each end of the box. To these posts are fixed the ordinary gear of a draw-well, the chain being, I think, divided to hook upon rings on the sides of an inner box, which has holes at the bottom. When the fish are required, the sluice is opened and the fish of course retire into the deepest water, which is the inner box. The box is then wound up, fish and all: this is easily done since the water runs out through the holes in the bottom."

Ponds which have laid dry for one summer are the best for breeding. There should be rushes and waterplants about for fish to deposit their eggs. I also strongly recommend that when fish, such as carp, are 
about to breed, which will be from May to July, that common wattled hurdles should be placed on the top of the water and fixed there by posts. These will not only afford places for the fish to attach their spawn, but will also answer as hides, and nothing is more important in fish cultivation than to give them hides. On the whole, I think that fish-ponds are generally made a great deal too deep. There should be a deep hole or two where the fish may run for protection, but the general depth of the pond should be shallow, as fish like shallows, and it is more favourable for the multiplication of insect life. One often wonders where all the mud comes from. Without doubt it is mostly formed by dead leaves. These leaves, therefore, should be collected and burnt, or other means employed to prevent them being blown by the wind into the water. The American weed is a great nuisance in fish-ponds. I am sorry to say I do not know how to destroy it. The process therefore of drying the ponds will be, I think, the surest mode of getting rid of it. A dose of common salt may also be tried.

It must be remembered, that the more you feed your fish in ponds the quicker they will grow and the larger they will become. To feed fish in a pond I strongly recommend that a dead cat or rabbit, unskinned, should be hung up in a tree over the pond. The gentles resulting from the blow-flies will fall into the pond and afford excellent food for the fish. Care should also be taken to collect after a shower at night, by the aid of a lantern, the large lobworms that are then plentiful. The fish should be always fed at the same place.

A curious fact has come to my knowledge relative to the cultivation of fish-ponds. A gentleman in Gloucestershire had some roach, dace, eels, carp, \&c., in a pond, 
but they did not increase in size or numbers. Some ducks were then allowed to have the run of the pond; since that time the fish grew to a larger size and also bred more than before.

When working the oyster experimental ponds at Reculvers, near Herne Bay, Kent, Mr. Port, who has charge of the marshes, informed me that he could tell if he handled the eels in the dark from which stream they came. In a particular stream the eels were small and poor, whereas in another stream not far off the eels were fat and large. He and his father before him could never account for this, except from the fact that ducks and geese are kept on the marsh stream where the eels were good, whereas they are not kept where the eels and other fish are thin.

I fancy the meaning of this is that the ducks are continually disturbing the mud in the pond with their bills, and that thereby the mud is loosened, and the fish, whose organs of taste are better than those of the ducks, follow up the ducks and eat the minute creatures which they have left; while the mud being loosened, gives facilities to the water creatures to breed. The ducks should be kept away when the fish are spawning, as they will eat the fish-eggs.

Should these observations on the cultivation of fishponds be taken up in practice, I should be very glad indeed, as throughout the country there are so many ponds now doing nothing at all which our forefathers went to great trouble and expense in maling as ornaments and recreation places to the family mansion.

Finally, to those who wish really to take up the important subject of pond cultivation, I most strongly recommend a very able book published this year, which gives not only information about sluices, banks, nets, 
\&c., but also a short outline of plants and insects living in ponds, as well as of pond-fish as cultivated at the present time in Germany. The title of this book is "Lerbuch der Teichwirthschaft. Ein illustrirter Rathgeber fur angehende sowie erfahrene Teichwirthe fur Gutsbesitzer und Fischereifreunde. Von Carl Nicklas herrschaftlicher Renten-Verwalter und Guter Inspector. Mit 84 Holzschnitten." Stettin : Druck und Verlag von Herrcke and Lebeling. 1880. 


\section{FISH FOR ACCLMMATISATION.}

This book would not be complete if I did not take the opportunity of giving the public the results of my experience as to the acclimatisation of fish, and at the same time stating what prospects we have of succeeding in the future in this desirable object.

By the acclimatisation of fish I mean that, not only is it possible to obtain from other countries fish not as yet known as British fish, but whereas we have already in our waters some of the best fish in the world, that it would be desirable to improve their breed by transferring them from places where they are already found in abundance to other places having a similarity of soil and climate.

I will now give a short description of each of these fish.

\section{SALMONIDAE.}

\section{SALMO SALAR.}

I AM of opinion that the strain of British salmon might be very much improved by crossing the breeds indigenous in the various English rivers. I have stated this more than once before Committees in the House of Commons. The eggs should be taken from spawning fish, hatched out artificially, and the young ones turned down into the upper waters of the rivers. I am sure, 
also, that the breed of English salmon would be greatly improved by obtaining ova of the Rhine salmon-the finest salmon in the world-as infusion of the blood of these would, I am convinced, have very beneficial effects upon the stock of many rivers which I could mention.

As regards the Californian salmon, I do not know yet sufficiently about him, and what I have seen of him I do not like.

\section{SALMO HUCHO. \\ (Salmo Hucho, or Danube Salmon.)}

OF this fish much has been said and written as being a desirable fish for this country. This fish spawns in the tributaries of the Danube. It is said to spawn in the months of April and May in swift-running water. My friend, Max von dem Borne, says he is a good rodfish, but very shy. He has the habit of lying quite still like the pike. I have the head of a Hucho. The teeth are very formidable, not unlike the teeth of the pike-perch. He is said to attain the weight of from $601 b s$. to $1001 \mathrm{lbs}$. On the whole, I give my vote against introduction into this country.

\section{SALMO FONTINALIS.}

\section{(The Brook Trout-The New York Charr.)}

THe next fish for acclimatisation which I strongly recommend is the Salmo Fontinalis, or Brook Trout of America. The first specimens ever seen in this country were sent to me, beautifully packed with moss in tin boxes, by some friends in America. The parent fish were obtained from Lake Huron in Canada. Since that time the import of eggs of Fontinalis has become a 
regular business, and they are advertised by English agents every winter.

Salmo fontinalis is a most lovely fish. Its dominant colours are green, dusky green of various hues mottled with yellow spots, the spots having a beautiful blue or carmine speck in the centre; the belly is silvery white, with a roseate tinge; the pectoral fins have a beautiful margin of a cream-white colour. I cordially recommend it for such places as ornamental fountains in gardens and small ponds. It requires regular feeding and looking after. They would do well on gentlemen's estates where there are small brooks and trout streams. They should be fenced in, or they may possibly escape.

I have some splendid specimens at my museum, South Kensington, one, two, and three years old. I have also bred from them in captivity for the last three or four years. These fish will breed in the third year; some however will give eggs in the second year.

Of this fish Rooswelt writes: "Brook Trout are in season from the 1st of February to 1st of September in the Long Island streams, from May to September in the middle and eastern States."*

Frank Forrester, in his "Fish and Fishing," + tells us that his manners, haunts, mode of feeding, \&c., closely resemble those of the European trout; and the flies, baits, and general style of tackle are the same in both instances.

These fish are found along the shores of Lake Superior, the lakelets of New York, Maine, New Hampshire, and the Canadas, Lake Nipissiguit in New Brunswick, the tributaries of St. John, Merrimac, \&c.

* "The Game Fish of the Northern States." Carlton, 430, Broadway, New Ycrk.

† Townsend, publisher, New York. 


\section{NON-MIGRATORY TROUT.}

IT is among the non-migratory Salmonida that we may expect, and, in fact, have already gained, the greatest success.

\section{GREAT LAKE TROUT.}

In the great lakes of Switzerland, especially Neuchâtel and Geneva, there exists that splendid fish, the Great Lake Trout. For many years past I have yearly received some splendid eggs of the Great Lake trout from the late Dr. Vouga.*

These Great Lake trout, when the spawning time arrives, are compelled to run up the tributaries to lay their eggs. At this time they are caught by those who have permission from the Government authorities; the eggs are taken from them, and a certain proportion of the young turned back into the lake. I have a very high opinion of these Great Lake trout. Both as eggs and fry they are very hardy, and they are most suitable to turn down into lakes where, of course, there are no pike.

More especially are they suitable for large pieces of water, such as reservoirs which supply towns, \&c. At the request of $\mathrm{Mr}$. Alderman Smith, of Manchester, I turned down a large number of these fish in Thirlmere Lake, where in future years they will doubtless afford excellent angling to tourists and the Manchester people.

Every year I grow a new generation of these fish at my Museum of Economic Fish Culture, South Kensington. Specimens in the tanks have become very tame, and I have grown them up to the heavy weight

* Dr. Vouga was Professor of Natural History at Neuchâtel. He was one of the most learned pisciculturists I ever met. I regret much to say he lately died of heart disease. 
of 2lb. 2oz. The wild mother-fish in the Swiss Lakes, from which these eggs are taken, average $12 \mathrm{lbs}$. to $14 \mathrm{lbs}$., the father-fish are sometimes as heavy as $201 \mathrm{bs}$. Those who require eggs of the Great Lake trout should order them from my Secretary, Mr. Searle, who is in direct communication with the official authorities who have the disposal of them in Switzerland.

\section{COMMON TROUT.}

Many of my friends who have trout fisheries and also hatching apparatus are now in the habit of catching their own fish and breeding from them.

Eggs of the common trout can also be obtained from Germany, through English dealers in trout eggs.

TRANSFER OF TROUT.

Many readers of this book may have ponds, but yet no breeding apparatus. To these I would recommend the plan of catching the small trout in the brooks and putting them into the ponds. Fish thus transported should be yearling fish, i.e., from 4in. to $6 \mathrm{in}$. long.

They should be turned down in the shallowest part of the pond, and it would be all the better for them if a portion of the pond be hurdled off so as to keep them from the pike. They must be fed in their new homes.

\section{VENDACE.}

There is a fish that exists, so far as I know, only in Loch Maben, in Scotland, where it is said to have been introduced by Mary Queen of Scots. There must be many ponds and lakes in Scotland that are similarly situated to Loch Maben, and I strongly advise gentlemen possessing such opportunities to obtain permission of the proprietor to transport living Loch Maben vendace 
for experiment. The fish themselves must be trans- . ferred in carrying cans, as it would be impossible to breed them by artificial means.

\section{LOCH LEVEN TROUT.}

Trene is another trout with which sufficient experiments have not been attempted in large lakes and ponds. This fish is well known to anglers as affording excellent sport and being very good to eat. Sir James R. Gibson Maitland, Bart., Craigend, Stirling, N.B., breeds a very large number of them artificially every year.

I should say Loch Leven trout would do well for the Broads of Norfolk and Suffolk, where the water is not too sluggish and weedy.

\section{CHARR.}

A Great deal has yet to be done in Charr cultivation. The eggs of the charr are obtainable from dealers under the name of "Fera." Some years these eggs hatch out well, sometimes badly.

At my suggestion, my friend Mr. Fell, chairman of the Kent and Westmoreland district, fitted up an admirable nursery for young fish close under his drawingroom windows. I sent him up some young Swiss charr, which became quite tame and thrived admirably.

Charr are only found in deep mountain lakes. Pro. prietors of mountain lakes in Wales should look to their charr, which sadly require cultivation and pro. tection.

\section{SMELT.}

Among the Salmonida, the smelt, or sparling, requires more attention than he has hitherto received. There are so many instances on record of smelts doing well in purely freshwater localities, that whenever opportunity 
serves smelts should be captured from the head of the tideway and turned down. I do not say whether they will breed in fresh water, for that I do not know.

\section{FLOUNDER.}

Now that we are talking of estuary fish, I see no reason why experiments should not be made with common flounders. They are by no means difficult to transport.

\section{PIKE PERCH, OR ZANDER.}

\section{(Perca lucioperca.)}

German: Zandr, Sandra, Sandbarsch, Seebar'sch, Schill, Fogasch. Danish: Standart. Norwegian: Gjors. Swedish: Gos. French : Les Sandre. American : The Glass-eyed Pike.

Many attempts have been made to transport this fish alive to England. My friend Mr. T. R. Sachs has taken immense pains in this matter, and the following is his report to me of successful experiments to bring this fish over alive for his Grace the Duke of Bedford.

Mr. Sachs wrote the following interesting article in Land and Water, No. 644, p. 476, May 25, 1878: "Mr. Dallmer, chief fishing master of Schleswig-Holstein, relates in the "German Fishery Circular" of April, 1878, that he had the honour of being requested by the President of the German Fishery Association to supply his Grace the Duke of Bedford with about one hundred small Zander, he having many opportunities of observing the peculiarities of these fish in Schleswig-Holstein. It is well known that these fish are not plentiful in the Elbe and Oder, abound in the Danube, but are not known in the Rhine or Weser, although these two last are equally well suited for this species. In many Schleswig Iakes Zander are plentiful, in others not, although con- 
nected with one another, and to all appearance the same kind of water. A fishing master placed some Zander in a neighbouring lake, which had no communication. with the one the fish were taken from. But a flood came, and the whole of the Zander returned to their original home. Sand, stone, and clay ground they must have; they never thrive on a muddy bottom. Brackish water suits them also, as they are frequently caught in the arms of the Baltic Sea. The fishermen at Rendsburg and Nortorf say that in deep lakes the Zander come to the top. In less deep lakes they are more frequent at the bottom. They are a very shy fish. Mr. Dallmer came to the conclusion to get the Zander from shallow lakes, as he knew such fish were better to transport, and in winter they lived long in a fish box. He therefore wrote to the President that he would select fish of a larger sort: first, because small fish were weak; second, they would more easily fall a prey to larger fish; third, larger fish would soon after their arrival in England produce a family of English Zander. The President agreed with the plan proposed, and suggested keeping the fish a few days in the boxes, so as to use them to confinement, and thus travel better. Mr. Dallmer selected a trustworthy fisherman, Nielsky by name, and sent him to several neighbouring lakes. Some had been netted, and others were not fishable. He then went to Bordesholm; two German miles from there is the Bothkamper lake. The fisherman told Nielsky he had netted his water six weeks ago, and kept them alive for three weeks before he sold them in Kiel. He arranged to net once more and let Mr. Dallmer know when to fetch the fish, for at this time of the year (the end of January) the water is seldom in a condition to net, owing to the ice. However, notice was sent on the 27 th 
that the water had been netted, and seventy Zander caught. Meanwhile Mr. Dallmer had travelled to Hamburg to arrange about the fish carriers and transit with Messrs. Kuhnert, who send live fish to all parts of the world. They have sent live carp in a boat filled and hoisted with water to San Francisco and South America. Carp and tench can bear a deal of knocking about, but not the delicate Zander. Messrs. Kuhnert once sent about a thousand small Zander in a hoisted boat to London, and only three arrived alive, and what became of them no one knows. Messrs. Kuhnert provided four barrels of oval form, $4 \mathrm{ft}$. long, $3 \mathrm{ft}$. broad, and $1 \frac{1}{2} \mathrm{ft}$. high each, with handles attached, so that four men could easily carry one. When they arrived at the water the fish were in a box facing a stream, and as lively as possible. $\mathrm{Mr}$. Dallmer selected 24 fish, each about two pounds' weight -twelve male, twelve female, so as to procure as many marriages as possible. The fish had a rough two German miles over a frozen road to reach the railway to Altona ; on arrival at Hamburg, Messrs. Kuhnert placed the fish in one of their large boxes in the Alster Lake. This was Wednesday. The next ship to London was the steamer Capella, and to depart on Thursday night, January 31, from Hamburg. The Capella frequently carrios live fish for zoological and aquaria purposes, and the sailors are used to the care of them. The fish were transported in five carriers-four fish in one, and five fish in each of the other four. There were also three extra barrels of fresh watcr for the use of the fish. The carriers were full up to the top, so as to prevent any injury to the fish from the rolling of the ship. At twelve midnight the Capella started. The waves ran very high, a stiff north wind being out, the sea washing the decks of tho large ship. Half-way across it became foggy, 
and, ship going at half-speed, the voyage lasted sixty instead of forty-eight hours (air being pumped into the carriers by the fishermen and sailors every half-hour), arriving in London on Sunday midday. There they were met by servants of his Grace the Duke, who took charge of the carriers, and conveyed them to the railway station, about three English miles distant. The fish were there again supplied with fresh water, and started on the two-and-a-half hours' journey to Bedford. On arrival, carriages were in waiting to convey the fish to the estate, four English miles more, where his Grace received them in person at the door of his mansion. "Are the fish alive?" he called out. "Alle lebendig," answered Nielsky, the fisherman. It had now become night, and the fishermen had to transfer the fish to the lake by lantern light; twenty-three were very lively, the twenty-fourth being rather doubtful. His Grace had him cooked for dinner; four fish, two male, two female, were placed in one sheet of water, the others in a lake of about twenty to thirty acres, which was full of small fish but no pike, the gravelly bottom being eminently suited for Zander.

"This excellent result has succeeded-first, through the initiative of the much-esteemed President; second, there was no lack of money at the disposal of Mr. Dallmer; third, Mr. Dallmer's thorough knowledge of the habits of the fish ; fourth, having a trustworthy practical fisherman as conductor; fifth, the great assistance afforded by the railway and ship officials; sixth, the very friendly assistance of Messrs. Kuhnert, without whom the expedition would not have succeeded so well; and, seventh, good luck. The fish were taken from the Schleswig Lake on the 25th January, and arrived at their destination on the 3rd February, thus being nine 
days on their journey. After this who will say Zander will not bear transporting? Henceforth England possesses the celebrated aristocratic choice-eating fish, Lucio perca zandra, or pike-perch, thanks to his Grace the Duke of Bedford.

"Three previous attempts were made by my friend Alexander Seydell, of Stettin, and self, to procure the Zander from Stettin by sea to London. On the first voyage all the fish died; the second produced three live small five-inch Zander. They died in Mr. Frank Buckland's museum at South Kensington, and are now there preserved in spirits. The third voyage nearly proved a shipwreck, as the steamer was thrown on her beam ends, and all the gear on deck, the large Brighton Aquarium iron carrier included, were tossed into the North Sea.-T. R. SACHS." *

\section{PIKE-PERCH FROM RUSSIA.}

In May, 1880, Mr. Charles, of 9, Lower Grosvenor Place (late Arabella Row), kindly sent me a fish bought at Billingsgate, under the name of "shaddick," from Russia. I at once saw it was a pike-perch (Perca lucio, Perca). It weighed 81bs.

I found nine specimens on the slab, and he has been kind enough to give me the heads of all of them. Mr. Pike-perch has a formidable back fin, which, on being dried, I find consists of fourteen rays, the longest of which is nearly three inches. The point of each ray is as sharp as a needle, and the membrane which covers each spine seems to make a retractible sheath for the point.

The teeth of the pike-perch are indeed most formidable. At the tip of the upper and at the tip of the lower jaw there are two teeth, conical and exceedingly sharp.

* Note. - Should another experiment be tried, it should be with fry, not half or full-grown fish. 
The teeth in the lower jaw fit into cavities in the upper jaw. Both sides of the upper and lower jaw are armed with trenchant teeth. They look more like dragons' teeth than fishes' teeth.

The roof of the mouth is also armed with two rows of teeth, the two anterior teeth being much the longest. I have in my collection many specimens of fishes' teeth, but none, I think, so terrible as those of the pike-perch. The teeth of an animal indicate the food on which it subsists. I should say, therefore, that the pike-perch. is a most voracious and carnivorous fish, but still I think he must have different habits from the pike, as his teeth are differently arranged. Mr. Searle, on dissecting this fish, found that the stomach was thin, but very capacious; in it were the remains of a fish, which appeared to be very like that of another pike-perch. When examining the stomach the œsophagus felt very rough; I therefore dried the soft parts and found that the pike-perch had a pavement of teeth on each side of the gullet, as well as a set to correspond on the floor of the pharynx. The edges of the bones which carry the gills are also covered with tufts, which tufts are composed of very minute needle-pointed spikes of bone; these, when dried, look exceedingly pretty.

The subject dissected was a female full of roe. The eggs are very minute, smaller than perch; in fact, the zander, or pike-perch, is a voracious form of perch. Our friends Mr. T. R. Sachs and Max von dem Borne state that he is a free biter. I should certainly say his teeth indicate that he would snap at anything, and I should say very strong tackle would be required to catch him at all. I should say these fish frequent very large lakes, such as exist in Kussia, and where roach and other white fish abound. 
I understand from those who have eaten the pikeperch in continental cities, such as Hamburg, Berlin, Leipzig, \&c., that it is exceedingly good for the table. It is just possible, therefore, that a new business may be opened up of importing pike-perch to the English markets as an article of food from Russia.*

I have been frequently asked my opinion as to encouraging this fish in England. My opinion is that in certain places the pike-perch would be a most valuable addition to our indigenous fishes, both as a source of sport and food. They would not do any more harm than the common pike, and as long as roach and dace are allowed an annual close time in their breeding season there will always be plenty of food for them. I would not advise that they should be turned out in public waters, such as the Norfolk Broads, but I know many lakes and ponds not connected with any river where they would thrive admirably and be kept under proper control.

* The Sandra lucio, Perca sandra is found in nearly all the lakes and rivers of Russia. It likes clear and deep waters. In the lower Volga they are taken in the spring in very large numbers, and dried. It is calculated that $45,000,000$ are taken every year; and in the Delta of Couban they take annually 7,000,000 of these fish. There is a large export of the roe of this fish, which is sent to Greece and Turkey. This preparation, which is principally made in the Sea of Azov, and, above all, by the Cossacks of Couban, is said to amount annually from fifteen to twenty thousand pounds. The roes are simply taken out, placed in barrels, and salted. A considerable quantity of fat is found in the intestines. of sandras. This is collected and washed, and the oil derived from it is used as a substitute for vegetable oil during fast days. This oil is also used to a considerable extent in the preparation of caviare, i.e., the roe of sturgeon. I have this on the authority of a writer in the proceedings of the Acclimatisation Society of Paris. 


\section{THE SILURUS. THE WELS, OR SHEAT-FISH.}

(Silurus glanis. Mustela barbatula.)

German: Der Vels, Weller, Harsa. Danish: Malle. Swedish : MIal. French: Le Silure.

Mr friend Mr. T. R. Sachs has taken a very great deal of pains to obtain all the information he can relative to this fish. In Land and Water, January 20, 1875, he gives an abstract from Herr Max von dem Borne's "Handbucl der Angelfischerei Hempel and Barey, Berlin," as follows :-

"This fish is called the "Vels,' and also the "Waller Schaiden.' He feeds on fish, worms, and small fry, and especially frogs. During the day he hides himself in holes, weeds, under banks, \&c.

" He is seldom netted, but caught with night lines, baited with gudgeon. In hot weather he basks on the surface and then is caught by a harpoon or fish spear. They sparn in June and July near the banks. The eggs are of a greenish colour, not numerous in proportion to the size of the fish. It has been ascertained they hatch out in about 18 days. As a pond fish he does very well, and quantities are bred for the fish market, one of 8lbs. to 10lbs. being considered the best for the table."

The silurus grows to a very large size, and is said to take sometimes a goose, or a wild or tame duck (in this respect he is not worse than a pike). There are several casts of silurus in my museum, South Kensington. The first I received from $\mathrm{Mr}$. Sachs, in January, 1875. Herr Max von dem Borne was kind enough to catch this fish for us at Witsterwitz, near Berlin. He weighed 18lbs., and measured sft. 10in. in length. In 
general shape he is very like the Burbolt of the Trent; his eyes are tiny little specks; on each side of his nose he has two long feelers, tapering to a fine point; under the lower jaw there are several barbules; his teeth are very minute, hardly teeth at all. In each pectoral fin there is a formidable serrated spine which, by a most. intricate mechanism, he can lock and unlock, in fact, acting like a trigger.

In February, 1876, Lord Odo Russell, ambassador at. Berlin, kindly sent me, through Lord Arthur Russell, a magnificent specimen of the silurus. It measured $5 \mathrm{ft} .6 \mathrm{in}$. long, and weighed about $100 \mathrm{lbs}$. A cast of this monster fish is in my museum.

In 1862, or 1863, Sir Stephen Lakeman, who has an estate at Kopacheni, on the banks of the Argisch, a. tributary of the Danube about ten miles from Bucharest, brought over with him 36 specimens of silurus. Of these only fourteen were alive. I took down ten of them to my friend Higford Burr, Esq., Aldermaston Park, Reading, and turned them out into the large pond in front of the house. Some three years afterwards this: pond was let dry-the silurus had entirely disappeared.

On the 27th October, 1880, Lord Odo Russell brought to Woburn Abbey, from Berlin, seventy of the Silurus glanis in their second year. These Siluri were bred at Berneuchen, near Custrin, by Herr Max von dem Borne.

\section{THUNDER-FISH.}

(Cobites fossitis.)

Arour the same time that I took the silurus down to. Aldermaston, I also took some Thunder-fish. These fish also disappeared in an unaccountable manner. 


\section{GOLDEN TENCH, OR GOLD SCHLEI.}

I Ax happy to be able to report that through the efforts of Higford Burr, Esq., Aldermaston Park, these fish are now thoroughly acclimatised in this country. Relative to this successful act of introducing a German fish into Berkshire, Mr. Burr writes me in October, 1880, as follows :-

"Mr Dear Buckland,-Do you recollect being here when I dragged the pond and gave a dejeîner to the Volunteers in September, 1862. It was shortly after that that you sent me three gold tench, which, if I recollect right, you told me were given you by Sir Stephen Lakeman. I put those three tench into a pond by themselves; only two lived, but the survivors were luckily male and female. In November, 1864, I let the water off the pond in which they were, and I sent you several fish of $3 \mathrm{in}$. or $3 \frac{1}{2} \mathrm{in}$. long, the fry of 1864 , evidently of the fry of 1863 , and a number the size of minnows.

"The first time I ever saw gold tench was in Bohemia, between Eger and Carlsbad, in the year 1856. Whilst the horses of the eilwagen were changing I walked round the garden of the post, and there I saw two or three shoals on the surface. I saw they were not carp, and never before having seen or heard of gold tench, could not make them out; but subsequently talking of them to some friend, I discovered that they were gold tench.

"It was fortunate you gave those two gold tench to me, for being quite by themselves they bred much faster than if mixed with other fish; at least, so it seems to me, for I do not hear from the many friends and others to whom I have liberally distributed them, that they have met with the results that have risen from the one pair that you gave me. I have now two large ponds 
full of them, too full, in fact, for them to grow to a large size; but I have had them, from a small pond where there were but few, of 4lbs. weight.-Higrord Burr."

Golden tench have also bred freely at Woburn Abbey and also in Norfolk. I trust eventually they will be established in the Norfolk Broads.

The gold schlei is a very beautiful variety of the ordinary tench, of a most lovely yellow colour mixed with the gleam of gold-as the Germans have it, gold glanzende. His beautiful court dress is spotted with black spots which, like the patches as worn by ladies in George the Third's reign, tend very much to set off the hues in his magnificent colouring.

\section{CYPRINUS ORFUS.}

Local names: Cyprinus Orfus, Leuciscus Orfus, Idus Melanotus. German: Der Goldnerfing, Die Goldgelbe, Gose, Rotheorfe, Orfus Germanorum.

In March, 1874, Lord Arthur Russell wrote me as follows: "Ever since I first saw these splendid fish, Cyprinus Orfus, in the ponds of the Imperial Palace, Laxenburg, near Vienna, I determined to introduce them if possible into England, and I was encouraged by your successful introduction of the golden tench. My first attempt a year ago was unsuccessful, two gold orfes only survived of the batch my brother had obtained at Berlin. They are still living in a pond at Woburn Abbey. My second and successful attempt has been accomplished with the assistance of Mr. Kirsch, Director of the Association for Pisciculture at Wiesbaden; he sent me one hundred and fourteen golden orfes of last year's breed, about $2 \mathrm{in}$. long each, and two large specimens. They travelled from Wiesbaden in two tin cans 
in charge of one of the clerks of the association, and, favoured by the cold weather, they were all deposited, without a single loss, in one of the Duke of Bedford's ponds at Woburn Abbey."

This beautiful fish grows to the weight of 3lbs. There is a fine coloured figure of the golden orfe in "Blochs," vol. iii. p. 96.

In former times, before the arrival in Europe, towards the end of the last century, of the Chinese goldfish, the gardens and fountains of the little princes of the Holy Roman Empire were enlivened by golden tench and the red variety of Cyprinus Orfus, called by the Germans gold orfe.

\section{SPEIGEL CARP.}

Iocal names: Cyprinus Specularis, Cyprinus rex Cyprinorum, Speigel Karpsen. German:Der Leder Karpfen. French: Carpe armiroir; also Rene de Carpe, Carpe Acuir, Carpe a Grand Ecailles.

Is March, 1873, Lord Arthur Russell was kind enough to bring me up three grand specimens of the lookingglass carp, most worthily called Cyprinus rex Cyprinorum. Sixteen Speigel Carp had been sent alive to his brother, Lord Odo Russell, by Count Maltzan, who lives in Silesia. The three fish which had died in transit weighed 6lbs., $5 \frac{1}{2} l \mathrm{bs}$, and $5 \mathrm{lbs} .2 \mathrm{oz}$., and measured from 19in. to 22in. The greater part of the body of this fish is of the usual carp colour, and is quite soft like washleather, there being no scales whatever upon it; along the central line on each side of the fish there is a row of very large scales, some being two inches across, some not larger than a sixpence. These are of a golden colour, tinted with opal. Altogether they are not unlike the peacock feather. 
The leather carp is the name given to this fish when the big bright scales are absent, which is sometimes the case.

In May, 1873, Lord Arthur Russell kindly presented to me four living specimens of the Speigel or lookingglass carp. They were presented to Lord Odo Russell, ambassador at Berlin, by Count Munster.

Of these four fish two are now alive and well at my museum, South Kensington.

In October, 1880, Lord Odo Russell brought to Woburn Abbey from Berlin, six Cyprinus rex Cyprinorum bred at Trachenfels, near Breslau, by Prince Herman Hatzfeldt.

\section{PERCHES.}

\section{BLACK BASS.}

\section{(Grystes nigricans.)}

Among the perches that promise well for acclimatisation, the fish which seems to me to be the most suitable of all is the Black Bass of Canada (Grystes nigricans).

In December, 1878, Mr. Begg, a Scotch gentleman who has a residence at Orillia, not far from Lake Huron, brought to England some living specimens of black bass. These fish he caught in Lake Rosseau. They were the black bass of the St. Lawrence, the Huro nigricans, Grystes nigricans. Most of these bass were sent to Mr. Mason of Eynsham Hall, Oxford, and Mr. Begg himself took a number of them to Dunrobin Castle, the scat of His Grace the Duke of Sutherland.

It is to the Marquis of Exeter, of Burleigh House, Stamford, that English fish culturists owe the present acclimatisation of black bass into this country.

Mr. Silk, the able and successful pisciculturist to the marquis, has been twice to America at his lordship's 
expense to fetch these bass. Mr. Silk kindly gives me the following report of his expeditions; the pains he took to obtain success does him the greatest credit. He writes :-

All of the black bass that I brought in 1878 from the United States of America were taken from the Delaware River. I placed them in boxes floating in the stream ready to be taken away. On the day preceding the sailing of the steamer for England they were placed in the tanks I had prepared for them by the river side. We got them to the train without any loss, and on arriving in New York had them placed on the main deck of the steamer; it was then 11 p.m., we having left the Delaware River at 3 p.m. Up to this time I had no loss; my greatest trouble was the high temperature it stood at--78 deg. all night. I kept the water as cool as possible with ice. I stayed by the tanks all night pumping air every few minutes, and keeping people from meddling with them. When daylight came I examined the tanks and found five dead fish, which I removed at once. It was now 5 a.m., and the ship was to sail at 6 a.m. I got some men to assist me in changing the water in the tanks. I had one spare tank, which I filled first, then reduced the temperature from $75 \mathrm{deg}$. as it came out of the hydrant to 58 deg., then placed the bass in it, and so on until I had given them all fresh water. We sailed at 6 a.m. sharp. When we got out to sea a few miles, I made arrangements with two of the steerage passengers to assist me on the voyage. It was then 9 a.m. I gave them both instructions what to do. After this I arranged with my men to keep watch two hours each, and to relieve each other at meal times. I always took four hours' watch in the night. I then roused one of the men and gave over the fish in good order. If there were any dead I always took them out at once. I made it a point never to go to my cabin at night. We got on very well the first day, as it was cooler, but after this we got into the Gulf Stream; both the air and sea were very hot, the atmosphere 85 deg., and the water in the sea $78 \mathrm{deg}$. It was during these five days we lost the most fish. We cleared the water every day by straining it through flannel, all thick and dirty water we threw away and added some fresh water made by melting ice. The sixth day out we got into cooler weather, and the fish commenced to do better. The temperature of the atmosphere dropped to $57 \mathrm{deg}$. We used very little ice unless to make fresh water with. We kept on like this until we reached Liverpool, after ten days' passage. I now 
got fresh water and changed all the tanks. The fish did not object in the least, but were quite lively. It did not hurt them changing the water from American to British. I got them conveyed to the railway station and placed on a truck. We arrived in Stamford in due course, and on counting the fish I found we had 153. I left the Delaware with 250 , so that I had lost 97 fish in twelve days.

In 1879 I went again, and started from America with 1,200 black bass, and on arriving home I had 812, having done better than I did on the previous occasion. All of the black bass were for the Marquis of Exeter, he having borne all the expense of the experiment. Most of the fish were placed in a lake belonging to his lordship called Whitewater, near Stamford. Not any of them have been caught yet. From what I could learn they would be about half-a-pound each in weight, so that they had done very well. The first lot that were put in will be three years old in April, when they are expected to commence breeding.-October, 1880.

Mr. Forrester says the black bass is one of the finest American freshwater fishes, surpassed by none in the boldness of biting and by few in excellence upon the board. It attains the weight of 6lbs. or 8lbs. It is taken abundantly in Lake Champlain; but in the St. Lawrence and amongst the Thousand Islands it affords the greatest sport to the angler. It is also found in all the Canadian lakes.

American authorities state that the difference between this and the Oswego Bass arises merely from condition and feeding grounds.

\section{THE MURRAY COD.}

\section{(Grystes macquariensis.)}

Turs is an Australian Perch, which I am convinced would do well in this country. Mr. E. Wilson, whose name is so well known in connection with acclimatisation, was desirous to bring the Murray Cod over to England, and on May 21, 1864, some of these fish, of course small specimens, actually arrived alive in the London Docks 
on board the Lincolnshive. I went to the Docks to receive the fish. Mr. Thatcher, the steward of the vessel, reported to me that he had received on board the Lincolnstire, on Saturday, February 20th, 130 fish measuring from 2 in. to $2 \frac{1}{2}$ in. long. They were placed on board in excellent condition by Mr. Spragg, Secretary of the Acclimatisation Society of Victoria, and had been caught by the fishermen of the Murray Fishing Company at the junction of the Edward and Murray River; floated down the river to Echren, and thence forwarded to Melbourne by the Victoria Railway Company. The vessel used to transport them was a cask containing 50 gallons, measuring $3 \mathrm{ft}$. $5 \mathrm{in}$. at the mouth, and $4 \mathrm{ft}$. deep, the vessel being slung on gimbals. These fish all died suddenly on February 28th, in consequence, it is supposed, of clean water not having been given them. I give these details in case the experiment is tried again. The following is Mr. Wilson's character of the Murray cod in abstract :- $-\mathrm{He}$ is idle, he moves but slowly, and in consequence he cannot do injury to the young fish, which are generally so alert. $\mathrm{He}$ is solitary in his habits, he swims up little currents of water, and above all he easily accommodates himself to live in a water-hole-a water-hole being a large hole in the bed of the river always full of water, frequently found in the rivers of Victoria, when the great heat of the summer has dried up their course.

Rivers which refuse to carry the salmon would be favourable to the Murray cod. It is essentially a fish of fresh water. The Murray cod is said to grow in his own country to a great weight, such as $60 \mathrm{lbs}$.

The flesh of the Murray cod is reported to be excellent eating, and it is better than that of a good mullet.

In May, 1880, I received, through the kindness of Dr. 
Inglis and Mr. Foord, of Melbourne, three preserved specimens of this fish, which I am about to have set up as additions to my fish museum at South Kensington.

The Murray cod is also called the "growler;" he is able to make a curious noise in the water (see an account of the œsophageal teeth under the head of Maigre, p. 136).

\section{PARADISE-FISH.}

ON July 8, 1869, Mr. Simon, French Consul at Ningpo, arrived in Paris, bringing with him some fish hitherto unknown to naturalists. These were little fish which he had brought over alive from a brook in the neighbourhood of the rice-fields of Canton. They are small fish. The scales present all the colours of the rainbow, with vertical bands of yeilow, red, and blue, and lines of changing colours running from head to tail; the form graceful and softly rounded; the caudal fin long-forked and fan-shaped; the dorsal and anal fins very long. On July 21st they began to spawn, and Mons. Carbonnier, who had charge of them, discovered, to his astonishment, that the male began to swallow the eggs. Previously to swallowing the eggs the male had ejected bubbles, which did not burst on the surface of the water. The male deposited the eggs from out of his mouth and underneath the shelter of these bubbles, which formed a kind of nest. The parent fish both kept watch in the neighbourhood of the eggs. After a while the young fish were hatched out. Their mouths being so small it was difficult to procure food for them. M. Carbonnier solved the question by cutting up aquatic plants, and breeding monads and other animalculæ which the young fish found suitable to their wants.

Monads are minute crustaceans called Cyclops. Here, 


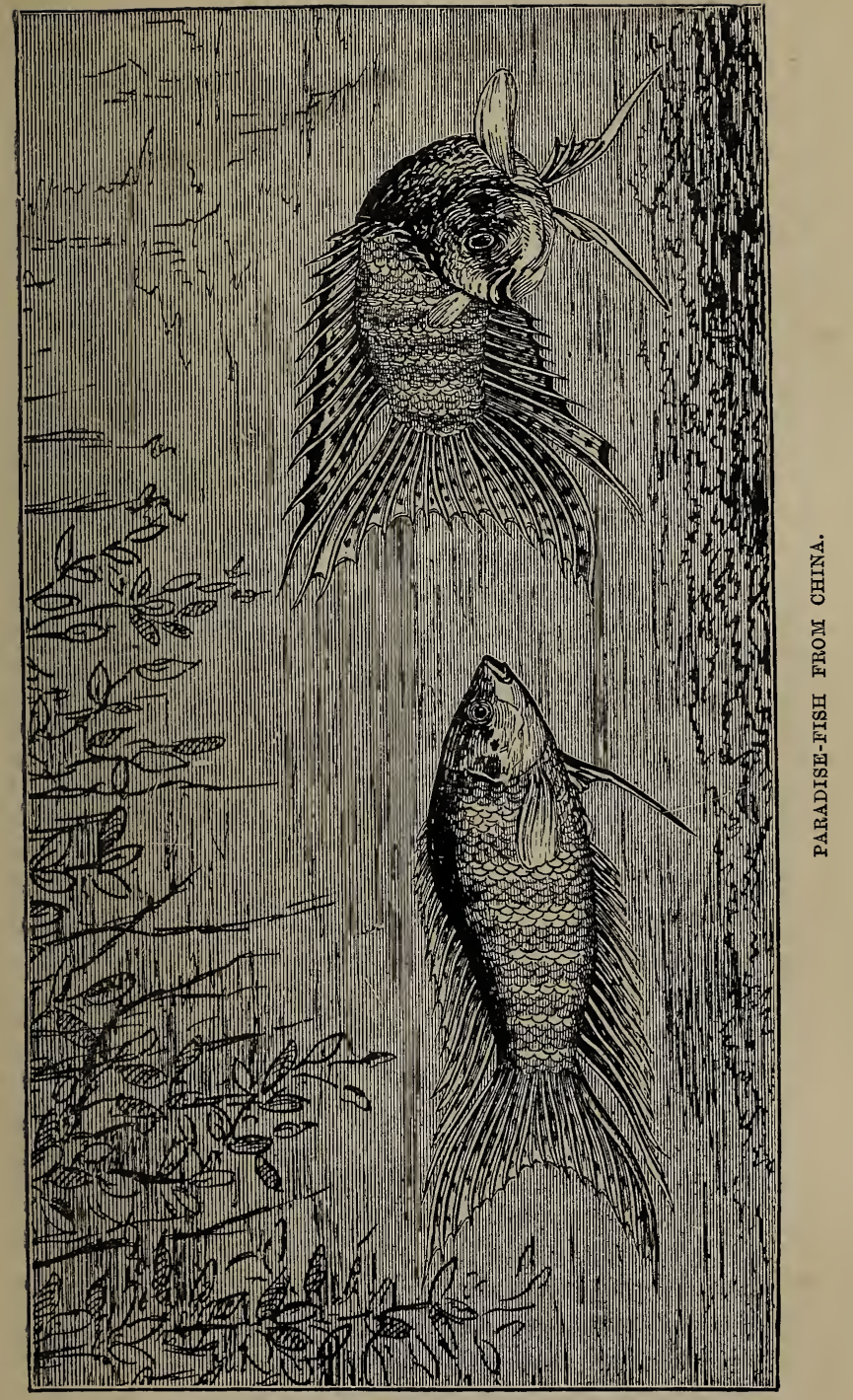


then, we have an excellent hint for those who wish to rear young fish which otherwise it is difficult to nourish.

On account of the beauty of these Chinese fish M. Carbonnier called them the Paradise-fish. He was kind enough to present me with a pair of them, and they lived some time in my museum, where they eventually died, I think, on account of its being too cold. They were certainly the most beautiful little fish I ever saw. They would, I feel convinced, do exceedingly well in this country, not, of course, as fish to turn out, but as aquarium or, to coin a phrase, a hot-house fish. Should any lady take a fancy to looking after these fish, keeping them in a warm room, feeding them regularly, and seeing that the water is properly managed, they would, I am convinced, become acclimatised in this country. It has been proved they will breed in France, why not, therefore, in England? M. Carbonnier has shown us how to feed the young ones, and I have no hesitation in saying that with proper care and attention they would thrive in England.

Should an opportunity occur, of course I should spare no pains to get these fish over from Canton and other parts of China.

\section{SUN-FISH.}

There has been alive in one of the aquaria at my museum, South Kensington, for some months past, a very beautiful little American fish brought me over by $\mathrm{Mr}$. Begg when he brought the black bass; this is the Sun-fish or Sunny (Pomotis vulgaris), a small species of Centrachus. Its extreme length is eight inches. It is ovoidal in shape, and is of most lovely colours-green, brown, and pale blue.

It is common in the middle and southern States, 
where they are caught by boys with worm bait, and who call them punkin seeds or kivers.

That sun-fish would do very well in any of our ordinary ponds I feel convinced, and I trust that some of our countrymen returning from America may be kind enough to bring some over. Small specimens should be chosen, and they should be carried in a large glass carboy and air repeatedly pumped into them with a pair of bellows; if the weather is hot add ice frequently.

\section{CAT-FISH.}

ANother fish that would do well in this country is the Cat-fish (Pimelodus). It is a species of Silurus, also called the Bullhead and Bull-pout. They are found in all the waters of North America. In some places it is esteemed a great delicacy, equal to an eel.

$\mathrm{He}$ is a greedy biter at a bait; he cannot be very difficult to carry, and the transport should be managed in the same way as the sun-fish.

\section{GOURAMI.}

(Osphromenus olfax.)

The Gourami is a freshwater fish, whose origin is in Cochin China, whence it has been imported successively to Penang, Malacea, Mauritius, Reunion, Cayenne. It belongs to the family of Labyrinthides. It has a labyrinthiform apparatus connected with the gills, which allows it to keep in a reservoir a certain quantity of water.

In warmish water, and with proper food and space, it grows quickly ; thus a fish at one year old, being 4in., would grow to 8in. in the third year.

Gouramis inhabit the lakes and ponds of Cochin 
China. They like water that is clear, and a little muddy at the bottom, with plenty of vegetation growing. The temperature which suits this fish best is 24 to 26 Centigrade-i.e., 75 to 79 Fahrenheit, and the temperature in winter must not get below 19 degrees-that is, 66 Fahrenheit.

These fish are herbivorous, as the length of their intestines indicates. In their native place their favourite food is plants which grow in the water of these countries, and besides these the gourami eats cabbage, lettuce, leaves of turnips, beetroot, maize, potatoes, arrowroot, carrots, biscuits, manioc; in fact, almost any vegetable farinaceous substances.

At the time of spawning the males and females choose a convenient place to make their nest and de. posit their eggs; this nest is made of aquatic plants. It is about 14 centimetres long, and is built by the male and the female in about a week. The female deposits from 800 to 1,000 eggs; during the hatching out the parent fish attend upon the young ones. When the fry are hatched out, they eat the vegetable portions of the nest which are softened by maceration. Gouramis begin to breed at three years old; it is at this time their flesh is best, and possesses an excellent taste.

Having published a portrait of the Gourami in Land and Water, October, 1880, I received a letter from my friend Mr. Jamrach, 180, St. George's-street, East, stating that he had two gouramis alive. The poor things kept sailing around and around their new abode as if looling for food. I tried them with a dozen different sorts of food, but with no success. At last I hit off the right food. When I placed it in the globe they rushed at it and devoured it most greedily.

Having fed voraciously they both wriggled up into the 
anacharis weed, and there remained with their heads uppermost and perfectly motionless for hours. I am convinced they were fast asleep.

These fish measure three inches long, and an inch deep at the shoulder.

The healthy fish of this pair is a regular beauty. He carries band marks down his sides of a lovely blue colour; his head also is silvery, and tinted with the sheen of the peacock-blue. Along his lower side he carries a keel of a very long fin. Each ray of this fin is tipped with a lovely spot of carmine red. As he swims about in the sun he is a very beautiful object.

Each fish has attached to the skin, near the lower aperture of the gills, two long feelers very nearly the length of the body. These feelers are continually moving about in the water, reminding me of a lobster in an aquarium playing his horns.

The gourami seems to use these feelers more as balancing poles than anything else.

Although they have plenty of water, both these fish come up very frequently with a rush, like a trout rising at a fly to the top of the water; here, with an exceedingly quick motion, they make a bubble of air, but whether they emit the air or take it in, I cannot decide. When the room is quiet, the noise made by these fish in this operation is like a drop of water falling with a noise that sounds like the word " pit" sharply pronounced.

I find that he has teeth at the tip of his very prehensile jaws. These teeth are so small that I can hardly malie them out; they feel with the tip of the finger to be rough like sandpaper.

Thus it will be seen that there exists a fish which promises extremely well to thrive in this country, and, so far as I am personally concerned, I shall lose no oppor. 
tunity in endeavouring to procure more living specimens. Should I be successful, the places where they ought to be turned out should be ponds where the water is warm, such as those in Yorkshire, where the water, being heated by the waste steam from cloth factories, is so favourable to the breeding of Gold-fish. Still better places than these would be the ponds or reservoirs constructed and already existing in large green-houses or establishments for forcing grapes, \&c. Of these so many exist attached to country mansions as well as town houses, the heat of which has not been suffciently devoted to experiments on animal life, though the success with vegetable life has proved indubitable.

\section{FISH CULTURE IN CHINA.}

In June, 1877, his Excellency the Chinese Minister, having heard that we English were considerably advanced in the science of fish culture, expressed his wish, through Dr. McCartney, to visit my Museum of Economic Fish Culture at South Kensington. My friends $\mathrm{Mr}$. and Mrs. Douglas Murray kindly made arrangements, and I had the honour of giving them and his Excellency a lecture in the museum itself.

Of course I could not understand a word in Chinese, the conversation being carried on by means of Dr. McCartney, who speaks that language quite fluently.

Before I could give any advice, it was necessary to know what were the natural fish of China. I therefore placed in the hands of his Excellency a light fishingrod, with a request that he would point out to me, from the casts on the walls, the kinds of fish like those in China. It was soon evident that salmon and trout, if found at all in China, are a rare fish. I conclude from what the Ambassador demonstrated, that the fish which 
are probably abundant there are all stagnant-water fish, such as are found in the lake districts of Norfolk and Suffolk. The fish to which his Excellency pointed were bream (Li-yu), carp (Nèn-yu), perch, eels, roach, and silurus. As regards salt-water fish, a species of cod called shek-pan, and a flat fish called Tsang-yu.

I was informed that fish were very much esteemed in China, and formed a large proportion of the food of the people, especially the poor. The price of them was one and a quarter li for twelve cash, but I cannot reduce this to an English standard. There is no legislation, no close-time, mesh of nets, or any other restrictions upon fishing in China. As far as I could make out, the principal mode of catching fish was by fixed engines, and if I understood right, stake-nets were greatly employed. These were often many miles in length, and the fish entrapped in them were kept alive till required for the markets.

Fish culture is much carried on in private ponds and lakes, and Dr. McCartney told me he had heard in China that an acre of water, properly cultivated with fish, was worth more than an acre of land, cultivated in the ordinary manner. His Excellency informed me that, although there was no close-time for fish in China, he thought they were more or less protected by natural causes in the months of May and June, when they are spawning; that is to say, by floods and inundations. The principal fishings are carried on in the winter time.

Having placed a map of China before his Excellency, he pointed out to me the big river called Yang-tse-kiang, or Ta-king, which has a catchment basin (or drainage sirea) of 742,000 square miles, whereas the catchment basin of the Thames is 5,500 square miles. 
He also pointed out a large lake called Tooing-ting, also some tributaries running into this lake-viz., the Siang, Yuen, and the Soo. This province of Hoonang, as well as the province of Quang-tung, the province of Fokien, and Kiangsi, were also great fish producers.

When we consider that there are more than $450,000,000$ of men, women, and children in China that have to be fed, the subject of fish culture becomes most important to China.

Soon after his visit to my museum, his Excellency most kindly dictated to one of his staff an outline of fish culture as at present carried on in China. This valuable document was written in Chinese, but $\mathrm{Dr}$. McCartney kindly got it translated for me.

The following is an abstract of the paper. The following are the principal fish in China : Lee, frequently weighs 40lbs., caught in winter - probably a large silurus ; Chi, delicate and well-flavoured, do not exceed a pound and a half; Lein or Yung, a large-headed fish of delicate flavour; Chao, greatly esteemed; T'sao, or grass-fish, kept in little ponds in the gardens of country houses, and Han-tse, or the red-eyed fish ; Plen, called the contracted neck fish, said to be excellent for the table, and one of the best in China; Poa-tino very palatable; Ching, a fish of a green colour; Lee, black and spotted like stars : on this account it is called the seven-star fish ; Chan, a very slimy fish, possibly a kind of tench ; Feh-toh, a well-flavoured fish ; Hwang-sang, has a dorsal fin as sharp as a knife; Shah, a small fish called also Mo wah; Tao, or knife-fish; Han, known as the yellow han; Chin-tsu, or needle-mouthed fish, taste very fine; Yin, silver fish, taste most delicious.

For further particulars as to this interesting and promising subject I beg to refer to that most valuable 
book, "The Special Catalogue of the Ningpo Collection of Exhibits for the International Fishery Exhibition. Berlin, 1880." Published by order of the Inspector General of Customs, Shanghai Statistical Department, 1880.

I am quite certain that many of the fish mentioned by the Chinese Ambassador would do quite well in this country, and now that the transport of fish for long voyages is thoroughly understood, I am in great hopes that I shall be able to induce the owners of our fastsailing tea-ships who come to the ports of London from China, to bring home samples of living fish. If gold fish were brought from China years ago, surely with our improved mode of transport we could get over specimens of the carp tribe.

RESUMÉ OF FISH FIT FOR ACCLIMATISATION.

Thus it will be seen that the fish which we may expect to do well in this country are as follows:-

FROM EUROPE.

Rhine Salmon, Great Lake Trout, Common Trout, Fera, Golden Tench, Cyprinus Orfus, Looking-glass or Spiegel Carp, Pike Perch, Silurus.

Total, 9 in number.

FROM AMERICA.

Salmo Fontinalis, Black Bass, Cat-fish, Sun-fish. Total, 4 in number.

FROM AUSTRALIA.

Murray Cod.

FROM CHINA.

Paradise-fish, Gourami, and I trust several others. 


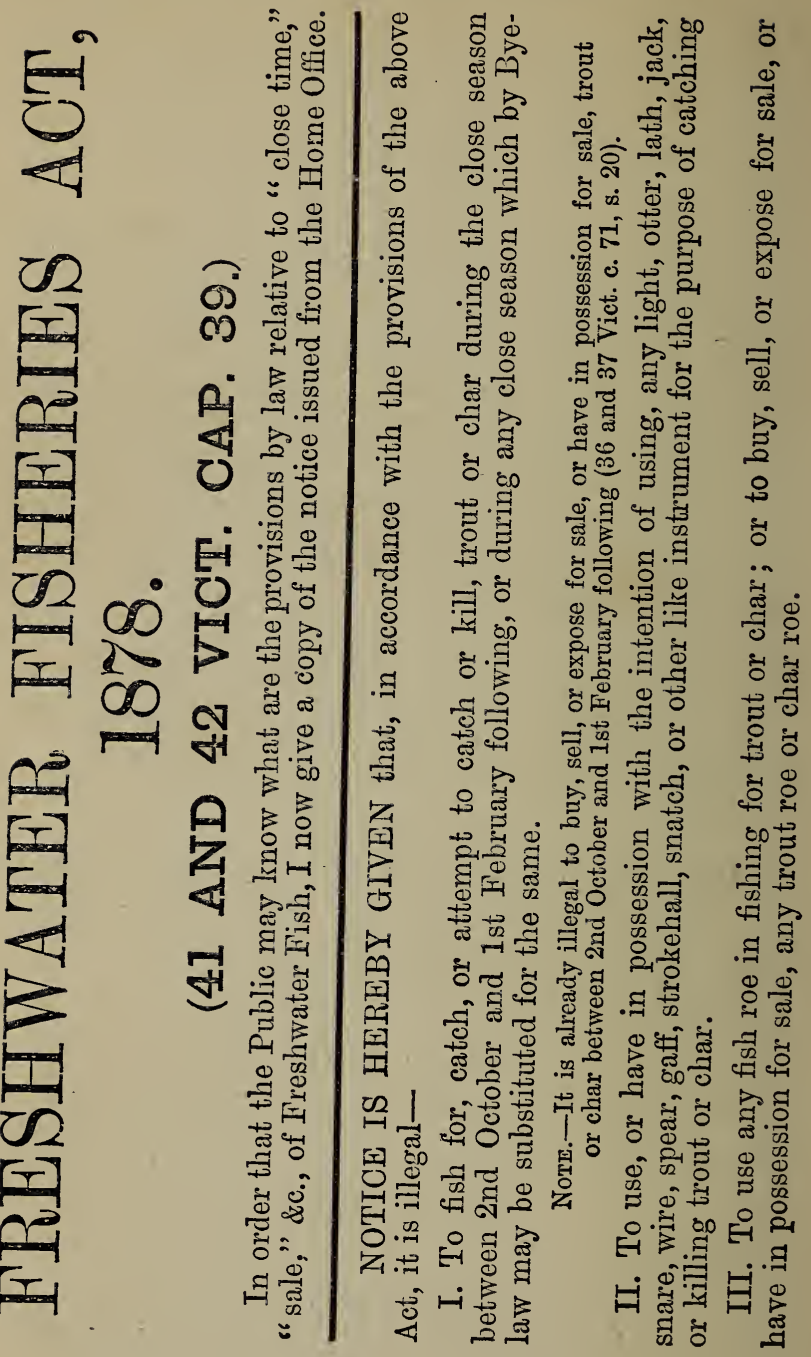




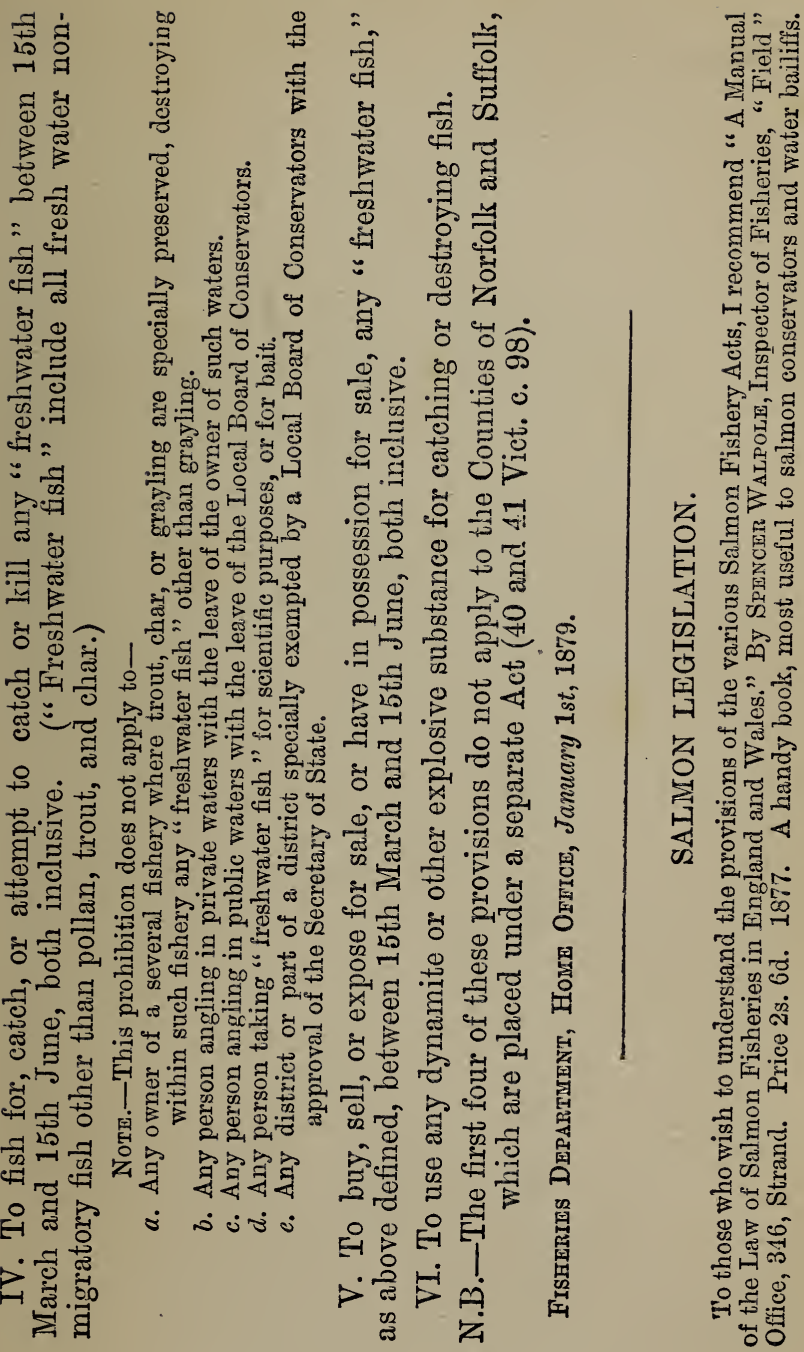





\section{APPENDIX.}

No. 1.

\section{WATER TELESCOPES.}

To those of my readers who spend their time at the seaside and are fond of observing living fish and other forms of subaqueous animal life in their wild state, I commend the use of the water telescope.

This efficacious and cheaply-made instrument is not used so much in this country as its merits deserve. The Norwegian fishermen are constantly in the habit of employing it in their herring and cod fisheries, and often thereby discover shoals of fish that would otherwise escape their nets. On the surface of the water in the sea and also in most rivers there is generally a ripple, which prevents the bottom being seen; it is to get rid of this ripple that the water-glass is so useful. There are three forms of water-glass, namely, an ordinary bucket or barrel with the bottom knocked out; secondly, a piece of tin of a funnel shape, about three feet long and nine inches diameter at the broad (or bottom) end, and large enough at the top to accommodate the observer's eyes-into the broad end should be inserted a plate of strong glass and some lead to weigh it down; thirdly, the simplest way is to get a tin or zinc tube like a map case. This should be about three and a half feet long and three inches in diameter. The bottom of this also should have glass and be weighted. When the water is clear this instrument will enable the 
observer to see from three to twenty fathoms on calm bright days. Of course when the water is thick the glass is useless. The Cornishmen, especially at the Lands End, use these instruments for looling for nets, lost crab and lobster pots, \&c.

In the Museum of the Royal Artillery, Woolwich, is a model of a water-glass consisting of a square box of wood, six inches each way; a round piece of glass somewhat larger than a watch-glass is let into the top and the bottom of the box is formed by a square of glass let into the wood about one foot square; the inside of the box is blackened.

This model is exhibited by Captain Fred. Robertson, R.A., who, upon a label close to the model, has placed the following information :-

"At Halifax, Nova Scotia, I was ordered to weigh a 24lb. gun, which had fallen into six fathoms of water. By means of a water-glass, I was enabled to see its exact position at the bottom. I then got a gunner to dive, with an iron bar, which, with a rope attached, he inseried into the muzzle of the gun. I then passed a running-noose over the rope attached to the iron bar fixed in the bore. The diver then passed the rope under the gun until the noose was before one trunnion and behind the other. The gun was then brought to the surface by means of a capstan."

To the naturalist water telescopes will be invaluable, as by means of them the actions of the fishes and other inhabitants of the ocean can be observed better than in any aquaria. The beauties and luxurious growth of the submarine forests of sea plants will adso to many be a most novel and interesting spectacle. To water parties who picnic on rivers or near lakes the water telescope will be found a great adjunct to the day's en- 
joyment, as by means of it subaqueous scenery may, possibly for the first time, be brought into view, and many a beautiful panorama opened up to the human eye. This glass would be most useful for roach-fishing parties. When a deep place in the river has been baited up for the afternoon and evening fishing, the swim may be interviewed with the water telescope, and if there are no fish there another spot may be chosen.

The punt fishermen of the Thames, when they are angling for gudgeon and other bottom fish, would also derive great amusement in watching the actions of the fish they are endeavouring to catch.

An idea has been suggested to me that it would not be a bad plan to insert in the bottom of the "wells" of punts a piece of strong plate glass-of course this must be protected.

No. 2.

\section{MUSEUM OF ECONOMIC FISH CULTURE, SOUTH KENSINGTON.}

Is the foregoing pages I have made frequent reference to casts and other preparations of fish in my museum.

Under the auspices of the authorities of the Science. and Art Dupartment of the South Kensington Museum I have been allowed to exhibit my collection in their galleries. The collection of this Fish Museum has occupied me since 1863 , seventeen years. The museum is my own property, but the cases are lent by the Department.

I trust the time will come when fish culture, as demonstrated by my collection, may be considered a worthy subject of education as increasing the fish food of the people.

My establishment has, I am happy to say, become. the consulting and reference room, not only for my 
fellow countrymen, whether interested in sea or river fisheries, but also for gentlemen officially concerncd with fish culture in other countries such as Germany, France, Russia, Australia, America, New Zealand, \&c.

Hoping that this book may be the means of recruiting many to the good cause of fish culture, I now take the opportunity of giving an abbreviated catalogue of my museum's contents, trusting that my readers may be induced to pay it a visit, and learn practically the lessons which $I$ have endeavoured to teach, whether in my official or private capacity.

Where not otherwise indicated, the numbers denote casts in plaster, every one of which I have made with my own hands, assisted by my secretary, Mr. Searle, and Mr. Edon, the curator of the Museum. In support of my Museum I receive a small annual grant from the Department.

\section{CETACE $\Lambda$.}

White Whale : Bottle-nosed Whales, Porpoises, \&:... $\quad$.. 7

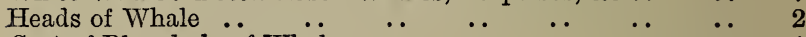

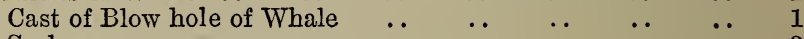

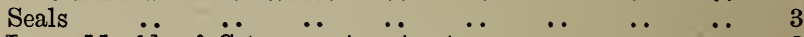

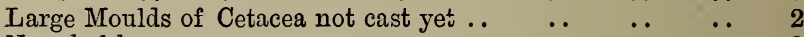

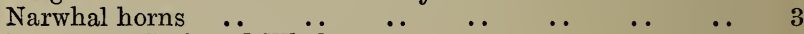

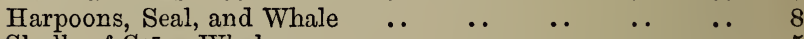

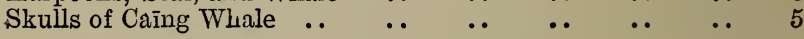

SALMON.

Monster Salmon in Cases Kelt Salmon Heads of Salmon ... Casts of Salmon (Single)

$$
\begin{array}{rrrrrr}
\ldots & \ldots & \ldots & \ldots & \ldots & 4 \\
\ldots & \ldots & \ldots & \ldots & \ldots & 14 \\
\ldots & \ldots & \ldots & \ldots & \ldots & 8 \\
& \ldots & \ldots & \ldots & \ldots & 67
\end{array}
$$

\section{TIOUT.}

Casts in Cases

Groups

Single Casts

$$
\begin{array}{lllllllr}
\ldots & \ldots & \ldots & \ldots & \ldots & \ldots & \ldots & 7 \\
\ldots & \ldots & \ldots & \ldots & \ldots & \ldots & \ldots & 7 \\
\ldots & \ldots & \ldots & \ldots & \ldots & \ldots & \ldots & 45
\end{array}
$$


STURGEONS.

\begin{tabular}{llllll} 
Sturgeons, Large . & \\
Mould (not cast). Weight of Fish $5 \frac{1}{2}$ crvt. & . & .. & . & 3 \\
\hline
\end{tabular}

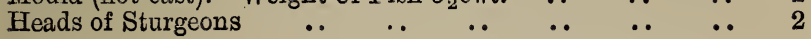

SEA FISH.

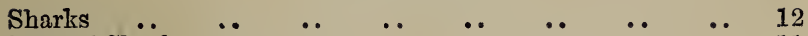

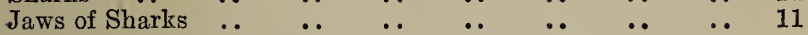

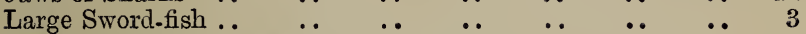

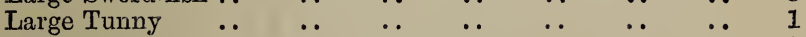

$\begin{array}{lllllllll}\text { Large Skates } & \ldots & \ldots & \ldots & \ldots & \ldots & \ldots & \ldots & 1 \\ \end{array}$

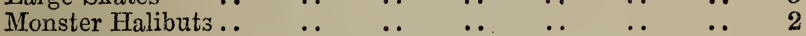

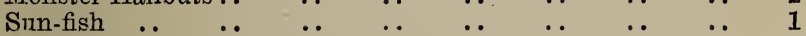

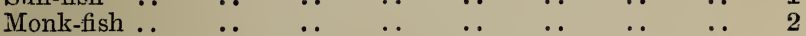

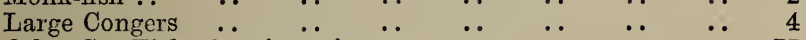

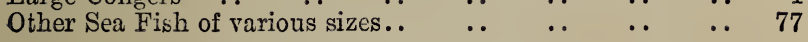

FRESHWATER FISH.

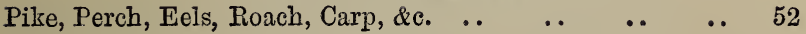

MODELS.

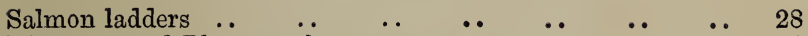

Diagrams and Photographs $\quad \ldots \quad$.

Large Glass Case containing Models of Salmon passes, Weirs,

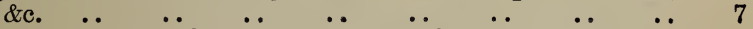

Pughley's Patent to keep tin plate pollutions out of rivers .. 1

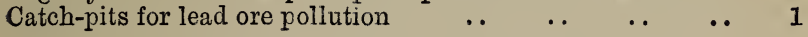

FISH BREEDING ESTABLISHMENTS.

$\begin{array}{llllllllll}\text { Photographs } & \text {. } & \ldots & \ldots & \ldots & \ldots & \ldots & \ldots & 10\end{array}$

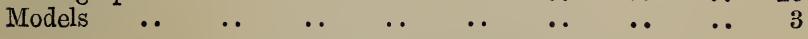

HATCHING APPARATUS. •

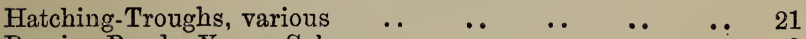

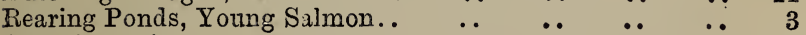

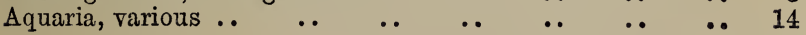

CUTTLE FISHES.

$\begin{array}{lllll}\text { Monster Newfoundland (Wood Model) . . } & \text {.. } & \text {.. } & \text {.. } & \mathbf{1}\end{array}$

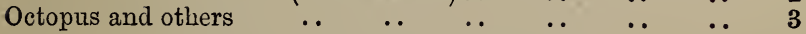

Fish Spears, various $\quad \ldots \quad$.

Cases of Crabs and Lobsters (Illustrating Crab and Lobster

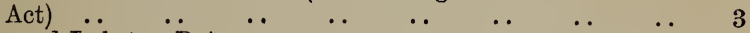

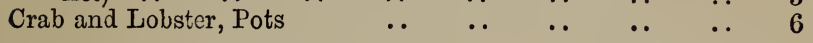


FISHING TACKLE.

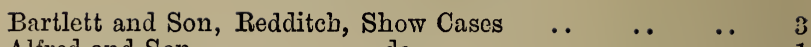
Alfred and Son, Farlow, Charles, Strand

Salmon and Trout Rods, Farlow Sea Tackle, Hearder of Plymouth Hounsell, Herbert, Bridport, Popes, Nets, \&c.

Sundries, Photographs, Nets, Carriers, Skins, Skulls, \&c.

CASES OF BIRDS.

Cases of Birds lent by Miss Dann

Do. do lent by Mr. Aitken

Large Case of Flamingoes

PHOTOGRAPHS OF AMERICAN FISHES.

Photographs of American Fishes

CASES CONTAINING OYSTER PREPARATIONS. Glass Boxes Illustrating Natural History of Oysters (about) 150

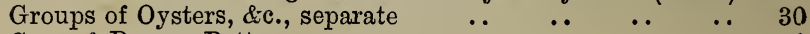

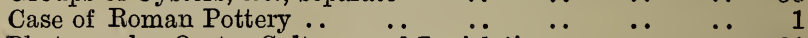

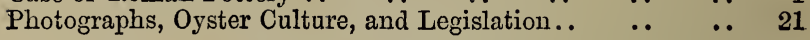

FISH PREPARATION.

Bottles Containing Fish Preparations .. $\quad$. $\quad \ldots \quad \quad \ldots \quad 120$

Do. do. Development of Salmon, Single Case .. 1 Total Number of Preparations .. $\quad$.

No. 3.

HAKES' TEETH.

(See page 110.)

Mr. Matthias Dunn has kindly followed up this subject for me. He writes as follows:

"I, like you, have seen marked on various Sea Charts. the soundings as "Hakes' teeth," and have wondered what it could mean.

"In the summer, 1868, this matter was cleared up by my brother. He was becalmed one night about twelve miles S.W. from the Bishop's Lighthouse, Scilly Isles, near where "Hakes' teeth" are reported in Charts. 
"With a long line he let down to the sea bottom a common galvanised iron pail, which in a short time got filled with debris. The common objects in it were sprays of white coral and some hundreds of what appeared to be the spines or hair from the backs of the Sea Mouse (Aphrodit aculeata), sparkling and iridescent as when giving beauty to the living animal. No doubt these were the reputed hakes' teeth as reported by sailors."

Another correspondent, my friend Mr. John Woodhall, of Scarborough, writes to me: "Your hakes' teeth as marked in soundings are small shells, either a dentalium or a ditrypa, most frequently the former."

I should be pleased to have more information on this point.

No. 4.

\section{WHALE AND THRESHER.}

Is September, 1880, Lord A. Campbell sent a letter to the Scotsman, describing a battle that he witnessed off Bellisle, from the deck of the s.s. Peruvian. This fight as usual was supposed to be between a thresher and a whale.

His lordship was kind enough to send me a drawing, which, though rough, was quite sufficient to throw great light, if not a full explanation of the phenomenon which he and the passengers of the Peruvian certainly saw.

His lordship says that he did not himself see the swordfish, and I still am of opinion that there was no swordfish there.

We now have to account for the thresher. In ordinary parlance, when we talk of a thresher-shark, it is generally understood that we mean the fox-shark (Carcharias vulpes), the fellow with the long tail, of which there are 
several casts in my Museum of Economical Fish Culture.

I am still of opinion that the fox-shark was not the animal that attacked this whale. The drawing gives me sufficient evidence of this, as the tail, \&c., is not that of the thresher.

What animal, therefore, could it have been that we see depicted in the sketch attacking the whale? I think I have discovered it. It was the gladiator dolphin, or sword grampus (Delphinus gladiator).

This grampus has very strong and sharp-pointed teeth, and is an animal of great boldness and strength.

These beasts are really great enemies of the whale, and they often hunt the whale in couples. They principally attack the young whales, but they are not above making an onslaught on an adult animal. There is, moreover, an excellent reason why the "sword grampus" attacks a whale. He is a very carnivorous fellow, and there is plenty of testimony extant that, having killed the whale, he and his friends will eat him. These grampuses are so carnivorous that they will also hunt seals, and catching them when they are swimming about the ice-floes, or else (as my friend Captain David Gray, of the Eclipse, Peterhead, whaler, told me) thrusting themselves up on to the edges of the ice, they will seize the seals off it, kill, and devour them. Nay more, when specimens of this whale killer have been cut open, the contents of the stomach, viz., portions of whales, porpoises, or of seal's flesh, show that he is accustomed to devour his fellow cetacea.

Thus, then, I beg to offer a further solution of the fight that Lord A. Campbell observed, and that many others also have recorded. 
No. 5.

\section{NUMBERS OF EGGS IN VARIOUS KINDS OF BRITISH FISH.}

$\begin{array}{llllllll}\text { Brill of } 4 \text { llbs. } & \ldots & \ldots & \ldots & \ldots & \ldots & \ldots & 239,775 \\ \text { Carp of } 14 \frac{1}{2} l \mathrm{lbs} . \ldots & \ldots & \ldots & \ldots & \ldots & \ldots & 633,350 \\ \text { Cod of } 201 \mathrm{lbs} . & \ldots & \ldots & \ldots & \ldots & \ldots & \ldots & 4,872,000 \\ \text { Cod, roe } 7 \frac{3}{4} \mathrm{lbs} . \ldots & \ldots & \ldots & \ldots & \ldots & \ldots & 6,867,840\end{array}$

Conger Eel, 28lbs., roe 23oz. ... $\quad \ldots \quad \ldots \quad 15,191,040$

Herring of $\frac{1}{2} 1 b . \quad \ldots \quad \ldots \quad \ldots \quad$ From 20,000 to 50,000

Jack or Pike, 32lbs., roe 5lbs.... $\quad \ldots \quad \ldots \quad \quad 595,200$

Jack or Pike, 28lbs., roe 21oz. $\quad \ldots \quad$... $\quad 292,320$

$\begin{array}{lllllll}\text { Lamprey of } 2 \frac{1}{4} l b s . & \ldots & \ldots & \ldots & \ldots & \ldots & 136,800\end{array}$

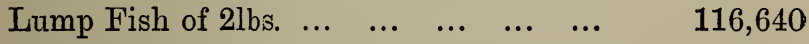

$\begin{array}{lllllll}\text { Mackerel of } 11 b . & \ldots & \ldots & \ldots & \ldots & \ldots & 86,120\end{array}$

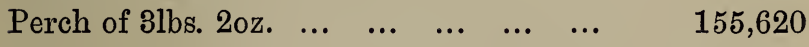

$\begin{array}{lllllll}\text { Plaice, 4lb. 15oz. } & \ldots & \ldots & \ldots & \ldots & \ldots & 144,600\end{array}$

$\begin{array}{llllllll}\text { Roach, 28lbs. } & \ldots & \ldots & \ldots & \ldots & \ldots & \ldots & 480,480\end{array}$

Salmon contains on an average 800 to

900 eggs to the pound of the fish's

weight. - A Salmon of 12lbs. about

10,000

$\begin{array}{llllllll}\text { Smelt of } 2 \mathrm{oz} . & \ldots & \ldots & \ldots & \ldots & \ldots & \ldots & 36,652\end{array}$

$\begin{array}{llllllll}\text { Sole of } 11 \mathrm{~b} . & \ldots & \ldots & \ldots & \ldots & \ldots & \ldots & 134,466\end{array}$

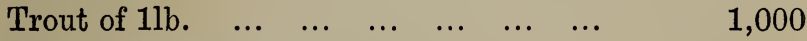

Turbot of 23lbs., roe 5lb. 9oz. $\quad \ldots \quad \ldots \quad 14,311,200$

Crab $\quad \ldots \quad \ldots \quad \ldots \quad \ldots$ From 1,500,000 to $2,000,000$ $\begin{array}{lllllllll}\text { Lobster } & \ldots & \ldots & \ldots & \ldots & \ldots & \ldots & \ldots & 24,960\end{array}$ Oyster (spats)

No. 6.

\section{ARTIFICIAL BREEDING OF SALMONIDAE.}

In order to render this book as useful as possible to the public, I now give short instructions how to breed salmon, trout, charr, and other Salmonidæ, by artificial 
means; a most instructive and useful occupation, to the study of which I have given much time and attention since 1862.

Throughout the country there are streams as well as lakes and ponds suited for trout which are now troutless. Trout are becoming so important, not only as food, but also for trout fishing, that wherever it is possible, I earnestly recommend that they should be bred artificially, and the waters thereby stocked.

The process of breeding artificially is so very inexpensive and so easily carried out, that with ordinary care it will probably turn out a success in most cases.

In the first place, then, it is perfectly useless to waste time and money in attempting to hatch fish in boxes out of doors by the side of rivulets, \&c., it must be done in-doors, or in a sheltered, easily accessible house or shed of some kind.

As regards water supply, there is hardly any house in the country, or even in town, that has not a cistern from which a sufficient supply of water cannot be obtained, say from the beginning of December to the end of March. Connected with stable yards, greenhouses, or other out-door buildings, there is generally water laid on for household purposes, and a tap in existence all ready to be utilized. The quantity of water required to hatch fish is about as much as would fill a half-inch pipe. It must be arranged to run day and night.*

The next thing to be considered is the boxes; these can be made either of wood or slate. The proper dimensions are three feet (inside) long, seven inches

* In case sufficient water cannot be spared from the house cistern, rig up an iron cistern or ordinary water-butt, to keep up the supply. 


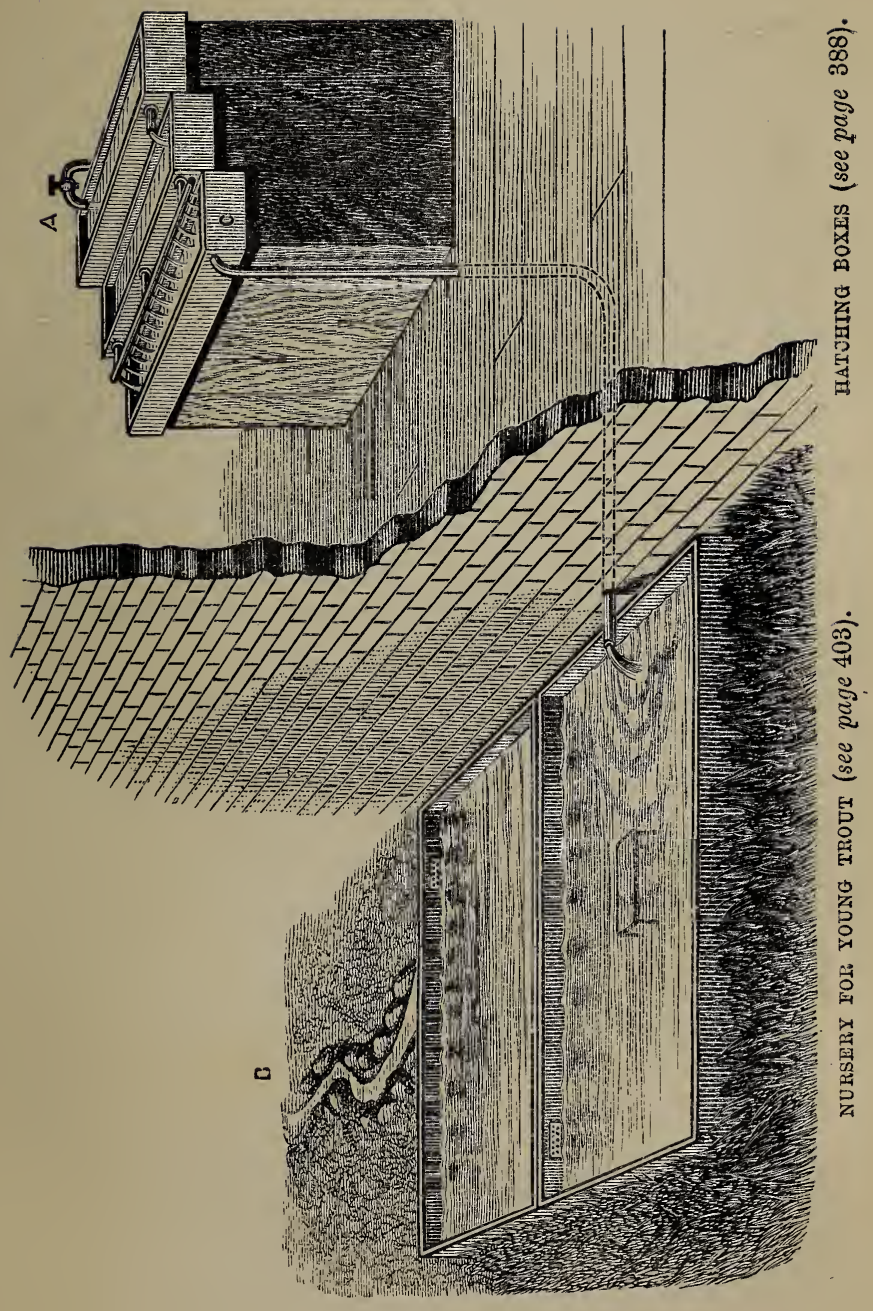


(inside) wide, and three inches and a quarter (clear) deep.* Each box of the above dimensions will carry from two to three thousand eggs. As will be perceived from the engraving (which represents the hatching apparatus at my museum), the boxes are placed one above the other, in such a manner that the water runs from the tap the whole length of box number one, then falling into number two, runs the whole length of that (only of course in the reverse direction). These boxes may be multiplied to any extent one above the other, but I do not like more than six, as when there are many fish in the troughs above, the fish in the lower troughs do not get sufficient oxygen. The water running from the lowest box should be utilised for the nursery as afterwards explained.

I am not at all an advocate for hatching eggs on glass bars; the parent fish do not find glass bars at the bottom of the river, but they do find gravel. Gravel therefore should be used for the hatching boxes. Gravel must not be taken from an iron soil; it should be well washed and even boiled before using; each piece of gravel should be about the size of a pea. It does not matter whether the gravel is angular or round. Its use in the box is to keep the eggs steady, and assist the young fish in hatching out. Half an inch of gravel in each box is quite sufficient.

It is advisable to divide off about two inches at the end of the box (where the water comes in) with a piece of perforated zinc, as this acts as a kind of catch-pit to stop any impurities that may happen to be floating down the stream. Partitions can also be made in the boxes with perforated zinc, so as to pen off the eggs of different dates or different species.

* Hatching-boxes made of slate in sets of three fitted to frame can be obtained from Mr. Edon, Fish Museum, South Kensington. 
To each box must be fitted a wooden lid with a hole cut for the entrance of the water; by means of the lid the eggs are kept in darkness, for eggs will never do well if exposed to the light.

Put in your eggs, then turn on the water, and now comes the most difficult part of the whole operation.

Having on one occasion a valuable lot of eggs which I was particularly anxious to hatch out well, I sent for my attendant, and made him promise faithfully to obey any instructions I gave. "Well then," I said, "will you be kind enough to do nothing at all, simply leave the eggs alone." By this I mean that it does not hurt the eggs to look at them, but it does hurt them to be continually pulling them about. Nevertheless, the lids of the boxes should be removed every morning, and the dead eggs carefully picked out. Dead eggs can be easily told from live ones. They turn a marble white and are quite opaque.

To show the elasticity as well as toughness of the horn-like shells of the eggs, drop one on the ground-it will bounce up like an india-rubber ball. It will also stand a considerable weight upon it. This is a beautiful provision to prevent the egg and its delicate contents being crushed in the gravel nest in which the parent fish deposit their eggs. Should a very heavy frost come on, place a covering of straw, hay, or sacking over the boxes and the supply pipe; the cold will not hurt the eggs, but if the water ceases to run, they will all be in great peril.

When I first began fish breeding, the great difficulty was to obtain eggs. Those who wanted them had to go out to collect them. Salmon and trout eggs are not picked up out of the bed of the river like hen's eggs off their nests. 
The fish must be caught in a proper net, the eggs taken from them and manipulated, the fish themselves being returned uninjured to the water. All this requires skill, and above all, if you do it yourself-and if you want it done properly you muss do it yourself -a knowledge of the habits of the fish, and considerable strength to manage the wet nets, as well as power to endure very great cold when wading in the water, and operating on the fish. I have frequently taken eggs when the weather has been so cold that the nets have become stiff as wire fireguards.

All these difficulties are now obviated by the fact that those who wish to breed young salmonidæ can obtain eggs all ready for hatching out from the various dealers in eggs, a list of whom is given at the end of this chapter.

Many failures and many experiments have now taught us the proper time at which it is safe to move the eggs, and has also shown the proper mode of packing them so that they will travel safely.

When a consignment of eggs is first received from the dealer, the bottles or bags in which the eggs have been packed should be placed in cold water and the moss cleaned away from them; the eggs will sink to the bottom while the moss will float. They should then be carefully removed to the troughs by means of a glass catcher.*

"A "catcher" consists of a portion of glass tube about nine inches long, slightly curved in the middle.

To use the eatcher properly, you must

(1) Apply the thumb to the one end, while the other end is placed opposite the eggs you wish to catch.

(2) Remove the thumb, and the eggs will instantly run up into the catcher.

(3) Place the thumb on the end of the catcher again. If this is properly performed, the eggs will be found in the catcher, and can then be transferred to the troughs. 
When the eggs are first received the eyes of the young fish are just visible as two small black specks. Oil globules can also be perceived, and the tail of the fish moving from side to side with rapid vibratory movement. It does not hurt the eggs when in this state to examine them, and if an egg be held up to the light, the young fish will be seen inside packed away in a most beautiful manner. The eggs themselves do not grow, that is they do not increase in circumference or diameter, but the fish inside certainly increases in bulk, till at last it becomes so large that the shell suddenly bursts, and out comes the young fish.

It is most interesting to watch the egg at the moment of hatching.

If you have luck you may happen to be gazing on a particular egg when of a sudden you will see it split in twain at the part corresponding to the back of the fish; you will then see a tiny head with black eyes and a long tail pop out, and you will see the newly-born creature give several convulsive shudders at his attempts to quit himself from the now useless egg shell (fig. 4). Poor little fellow, he can't manage to get out, the shell is too tight for him (see engraving); take therefore a soft hair pencil press lightly on the egg shell-he seems to know you are his friend-he gives another vigorous kick or two, and presto ! he is free and has commenced life. If we judge from his motions he must enjoy life, for away he swims as fast as his tiny fins and wriggling tail will carry him, round and round in a circle, and then plump down he goes to the bottom of the tank and reclines upon his side, breathing freely by his gills for the first time in his life (for when in the egg he does not and cannot breathe).

They cannot travel very far, their bag (their umbilical 

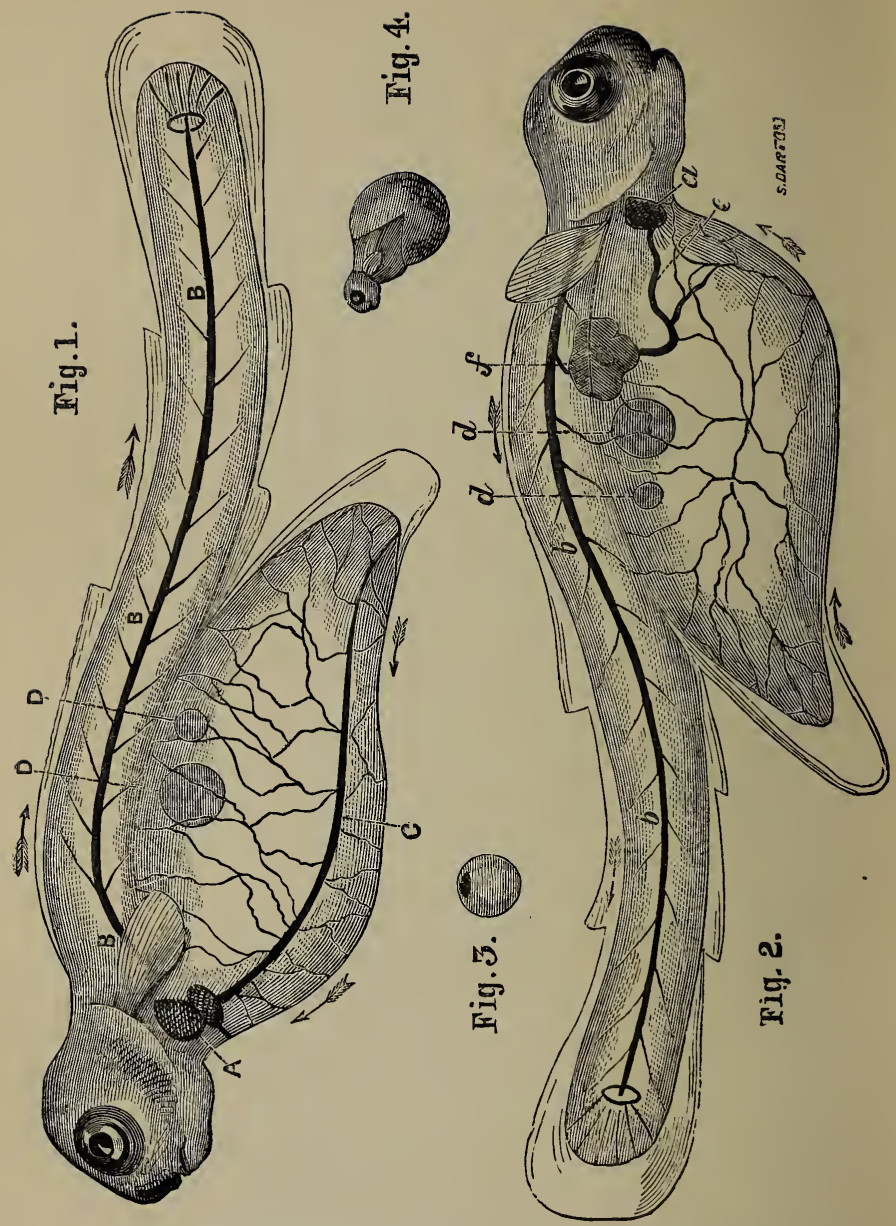

YOUNG SALMON JUST HATCHED OUT-AS SEEN UNDER THE MICROSCOPE. 


\section{EXPLANATION OF THE FIGURES OPPOSITE.}

\section{FIG. 1.}

Shows the left side of the fish (magnified 120 diameters).
A. The heart.
B. Main trunk artery.
C. Large vein.
D. Oil globules, only two of which are introduced, for the sake of distinctness.

FIG. 2.

Showing the right side of the fish.

a. The heart.

b. Main trunk artery.

c. The liver.

d. Oil globules.

e. Large vein from liver to heart.

$f$. Branch from main artery to liver.

\section{Fig. 3.-Salmon Egg.}

Fra. 4.-Young Salmon hatching out.

Noтв.-The bag attached to the fish contains the nourishment which is gradually absorbed into the body. As the fish gets larger the bag gets smaller, and the fish does not feed till the bag is quite gone, which is about six weeks or two months after it is born. 
vesicle) (see engraving) is too heavy for them, and soon brings them to the bottom, like a bullet at the end of a "paternoster" fishing-line. So far so good, but cannot we see and learn more about these young fish ? Get out the microscope, and place a new born salmon under a low power, and you shall see one of the most beautiful sights ever beheld by human eyes (see engraving). You shall see the tiny heart (A), which is situated just underneath the lower jaw, going pit-a-pat, pit-a-pat; you shall see the blood at one instant in one cavity of the heart (where it appears like a red speck), at the next instant it is at the other side of the heart, and so it goes on day and night, never ceasing, never tired-a great. forcing pump propelling the blood to all parts of the body, and gradually building up the frame of a future. King of fishes.

I counted the pulse of the salmon when it was under the glass, and ascertained that it averaged about sixty in the minute; I wonder how much it increases as he gets. older? Just below the heart can be seen in the umbilical vesicle (when the fish is in the water), a bright red streak; examine this under the microscope, and you will see that this red streak is in fact a great blood vessel; with a high power you can see plainly the minute blood-dises coursing along between the walls of the elastic tube.

The minor red streaks upon the umbilical vesicle can in the same way be made out also to be blood ressels, containing blood-dises, running along at a great pace.

Again, down the centre of the transparent body of the fish can be seen, with the unassisted eye, two streaks (в в в); the microscope shows that these also are bloodvessels, and that the blood in the one is running towards the head, in the other toward the tail. A more complete 
and beautiful demonstration of the circulation of the blood never was yet placed under the microscope.

The average weight of a young salmon just hatched is nearly two grains, forage bag and all ; he has therefore a good deal to make up before he is fit to lie on $\mathrm{Mr}$. Groves' marble slab.

The rate of increase of weight in the young salmon according to my late lamented friend Mr. Ashworth is as follows :

"At three days old it is nearly 2 grains in weight; at 16 months old he has increased to 2 ounces, or 480 times its first weight; at 20 months old, after the smolt has been a few months in the sea it becomes a grilse of $8 \frac{1}{2} \mathrm{lbs}$, having increased 68 times in three or four months; at $2 \frac{3}{4}$ years old it becomes a salmon of $12 \mathrm{lbs}$. to $15 \mathrm{lbs}$. weight; after which its increased rate of growth has not been ascertained, but by the time it becomes $30 \mathrm{lbs}$. in weight it has increased 115,200 times the weight it was at first."

I do not suppose there is any other animal that increases so rapidly and at so little cost, and that becomes such a valuable article of food.

In various creatures the progress of development is different; thus, for instance, in the human baby, the first portion of the body developed is the lower jaw, and this for an obvious reason, that is, because the most material want of the baby is to obtain the mother's milk by suction. Now if the lower jaw were not solid and firm, in vain would it try to suck.

But in the case of the fish, nature has kindly packed up all the nourishment that it will want for some six or eight weeks in a neat little bag or parcel, which she has affixed to the body of the fish in such a manner that it shall be gradually absorbed into the general system; 
the fish does not suck milk like a warm-blooded animal, so its lower jaw is not quite so soon ossified.

What is, then, the most important organ to the young fish? He has lots of enemies, and it is his first object to get out of their way. The eyes therefore are the organs which first arrive at perfection; and they are indeed perfection in this minute jelly-like creature.

The eye is in perfect working order at the moment of birth, though the rest of the body is far from perfection. The lens of the eye is amply developed, as can be proved by placing a dead fish in spirits of wine and observing that the lens turned white instantly it touched the spirit. Thus I was enabled to see, and accurately to judge of its size and shape.

The lining coats of the eye, moreover, are already at birth painted with a beautiful silver-and-gold lining, which the angler will see if he cuts open the eye of the next fish he kills. It is especially well seen in the eye of the cod ; and the reader may easily get one of these and examine for himself.

\section{THE MANAGEMENT OF THE FISH JUST HATCHED.}

WHEN first hatched out the young fish remain quite quiescent at the bottom of their troughs, looking like barley-sugar drops. When the light is admitted on to them, they simultaneously wriggle about like tadpoles.

Leave them alone. They do not require feeding. They live by absorption of the contents of their umbilical sac. After a while the little fellows begin "to scale"-i.e., scales to grow-giving their bodies a darkened appearance, and to move about more actively.

The moment the fish begin to hatch out, you must increase the flow of water. 
The quantity of water sufficient-say for three thousand eggs which do not breathe, is not sufficient for three thousand fish which do breathe; their little panting gills being at work incessantly day and night absorbing oxygen from the water.

At this time it is most important to keep a daily register of the temperature of the water; for young fish, though very tolerant of cold, are very intolerant to heat. Look also to your supply cistern. For when the spring suns begin to come out, the iron or slate of the cisterns is apt to absorb heat, and send up the temperature of the water used for breeding. This is often an unsuspected cause of mishap.

Once for all remember, that, when young fish are unwell, the almost only remedy you can give them is cooler water. The water may always be cooled by lumps of ice floated in the top trough.

You will find that as the young fish get able to swim about, they will all crowd up into the corner of the trough. This is not a healthy state of things; it may be remedied by causing the water instead of falling into the box in one stream at one end, to pour into it by many jets throughout its whole extent. This may be done either by making a pipe in the shape of a $T$ and boring holes in it (as may be seen in the pipe of an ordinary water-cart), or by a zinc or wooden gutter with holes bored in the bottom adapted in size to the stream of water that is required to run through.

In spite of all that you can do, after a while you will find the young fish will begin to die-this is a sure sign that they are too thick in the trough; you must therefore take out half of them and place them in another trough.

I cannot go into details, but the only remedy for 
stopping fish from dying is to decrease their numbers, and at the same time to increase the flow of water; every morning and evening the dead fish mustbe carefully picked out. If they are not picked out they will become covered with a white fungus, material resembling cotton wool. This terrible fungus sprouts and grows at an extraordinary rapid rate, and is very apt to kill the fish by giving them " gill fever." Gill fever is simply a growth of fungus upon the gills, which impedes the breathing of the fish, and, as you will see, the fish will die with his mouth wide open gasping for breath. This fungus is the Saprolegnia ferax, the terrible vegetable parasite, which has been the cause of the destruction of so many full grown salmonidæ in the Tweed, Solway, and other rivers, i.e., the " Salmon Disease."

The young fish soon after birth being intolerant of light, it is advisable to place in the troughs some " hides." These are best made by supporting upon four pieces of wood or stone, a slab of slate the size of an ordinary envelope; you will find the young fish will delight greatly in these "hides," going under them for concealment. Their instinct telling them that in their tender young days they have many enemies, among which ducks are not the least.

\section{ON FEEDING THE YOUNG FISH.}

WhEN the umbilical bag is about half absorbed, the young fish will require some food. Here there arises a very difficult problem. In former days-and even now sometimes-the trout and salmon breeder is told to feed his fish on grated liver. Grated liver to me is an abomination, it is not, I think, very palatable to the fish ; the particles that the fish do not catch fall down anong 
the stones and foul the water, to the greatinjury of the inhabitants of the troughs.

Another substance often used for feeding young fish, and which is not at all objectionable, provided the troughs be kept thoroughly clean, is the roe of soles. This is a discovery of the Marquis of Exeter, and he kindly told me about it. Here is a riddle. "What is smaller than a mite's mouth?" Answer: "That which goes into it." The mouth of the baby trout or salmon is exceedingly small. The roe of the sole is exceedingly small, small enough for the young fish to get it into his mouth and swallow it. The sole's roe of course must be boiled and broken up by the fingers.

I have of late years been fortunate enough to discover what is the very best possible food for young fry; this food consists of red mud-worms from the bed of the Thames. These worms being placed in saucers in the troughs, have the happy knack of twisting their tails together into a ball, while they move their heads about, giving very much the appearance of a ball of red plush. The wriggling motion of these worms attracts the attention of the young fish, and they will feed upon them greedily. The discovery of these worms as food for young fry is one of the greatest in modern fish breeding. These red worms, though plentiful in nature, cannot be obtained anywhere in London except from one man, whose name and address is Mr. Newman, 32, Thanet Street, Burton Crescent, Euston Road.

He will send the worms in a wet cloth. When not wanted for use, they will keep very well in a basin under a dripping water tap. 


\section{ON TURNING OUT YOUNG FISH.}

As the spring comes on and the weather gets warmer, it will be absolutely necessary that your fry should be turned out. There are two ways of doing this. First, either turn them out direct into the streams which you intend to stock; or secondly, keep them in nurseries until they are "yearlings," or even two or three years old.

If you have a large number of fry, I certainly advise that the greater part of them should be turned out at once in the open stream. This is so important an operation that you must not trust it to anybody. Find some tributaries-either brooks, rivulets, \&c.-connected with the stream you wish to stock; place your fry in a carrier, and walk down the stream, sowing it (as it were) with five to twelve living fish every ten or twelve yards.

Before you let your fish loose in the stream, construct with the pebbles at the bottom of the stream, or with a couple of bricks and a roof slate, hides for the fish. The fish should be caught out of the can by means of a small net made of cap netting and wire; sink the net with the fish very quietly into the water below the hide which you have built, and if you do this without hurry and with care, the chances are that the fish will immediately dart under the hide, which they will at once take to as a comfortable and secure home. The water in the brooks or rivulets where you turn out the fish should not be too rapid, and should have quiet eddies here and there. The little fish will soon make themselves at home in the brooks, especially if the water is not more than from three to six inches deep. About six inches is the depth which I prefer to turn out my fry. If bushes and trees over- 
REARING YOUNG FISH IN OUT-DOOR NURSERIES. 403

hang the waters where you turn out the fish so much the better, as they will entice insects, on which the fish will feed.

The very best places to turn out fish are watercress beds, where the water is clear and shallow, the watercresses growing on either side, and a stream running in the middle.

\section{FISH NURSERIES.}

Aцтночgh I advise that the majority of the fish should be turned out into the open, yet it is most advisable to establish a fish nursery. Firstly, to enable you to have some idea how your turned-out fish are getting on; and secondly, that you may have the pleasure of taming the fish of your own rearing-and fish so reared soon become tame, almost as tame as chickens. For this purpose dig a hole in the ground, have a large box, about eighteen inches deep made to fit into the hole; be sure the box is water-tight, or it will give you everlasting trouble; they may be of any size-the size I like best is about six feet long by three feet wide. The water in it must not be anywhere deeper than six inches, the little fry from the troughs will not thrive in deeper water, but as the fish get larger the water may be deepened; this is easily arranged by altering the position higher or lower by the outlet pipe. If you have space enough, a succession of two or three of these boxes may be placed end on to each other, and pretty little waterfalls instituted where the water runs over, while the edges may be ornamented with water plants according to the gardener's taste. In this manner fish nurseries may be made very ornamental adjuncts to gardens and pleasure grounds. (See previous page.)

The supply of these nurseries is readily obtained, as 
may be seen from the drawing, from the same tap as that used for the troughs. In this case I strongly recommend the water to be let in by the $T$ water-cart pipe, as above described. The more water you give the better for the fish.

Into your box you must put several hides; again, nothing is better than roof slate. In very hot weather an awning must be placed over the nursery to protect it from the sun, and throughout the whole year the lower half of the box should be covered with boards, under which the fish will retreat, and come out with a rush at feeding-time. In hot weather common duckweed placed in the nursery forms an excellent refuge for the fish. I do not in the least object to leaves accumulating in the nursery, they breed insects upon which the young fish feed. It is advantageous to turn in some common water snails, as the delicate young snails when first hatched out form a capital provender for the growing fry. Gnats and midges should also be encouraged, and it is a very beautiful sight to see the young fish in the evening time jumping clean out of the water, and catching the midges with the same grace and velocity as their fathers and mothers in the open river.

In the nurseries the young fish should be fed with the red worms placed in saucers, and as they get larger with fish food, the preparation of which has been hitherto more or less of a technical secret, but I now nevertheless publish it, in the hopes that it may be of service to many of my readers.

It consists of-

1. Raw beef without fat;

2. Arrowroot biscuit powder ;

3. Egg, both yolk and white. 
Pound well together in a mortar till of the consistency of ordinary dough; break into small pieces according to the size of the fish you have to feed.

If you feed your fish regularly-morning and evening is the best time-you will find that they will shortly get exceedingly tame, and cause by their gambols much instruction and amusement to yourself and friends.

\section{ON THE TRANSPORT OF FISH AND FRY.}

Nornivg is so difficult as the transport of fish when you do not know how to do it. Nothing is so easy when you do know how to do it.

In the transport of fish you must recollect that you cannot give them continual change of water. First, because when on a railway journey it is difficult to obtain water; and secondly, because the water when so obtained may possibly contain iron or some other substance injurious to the fish.

It is therefore necessary to add fresh oxygen to the water as you go along. This is done, firstly, by allowing the water to splash about as much as possible with the movement of the railway carriage; and secondly, by pumping fresh air into it; thirdly, by the use of lumps of ice. For the transport of fish to long distances, nothing is so good, when you cannot yourself accompany the fish, as the large glass bottles packed tightly into baskets with straw, and known as sulphuric acid carboys; your chemist will probably tell you where to get these. When the fish are put into them they must not be more than three parts full of water, so that there may be plenty of splashing in transitu. 
After trying many forms of hand carriers for young fish, I have come to the conclusion that nothing can possibly be better than that depicted in the drawing below.

It is a German invention, and the first I ever knew about it was from Lord Arthur Russell, who brought one over from Berlin, and kindly presented it to me. It will be seen in the figure of the section that it has a false bottom made of perforated zinc, below which is a bent pipe traversing round inside the bottom of the can. This pipe is perforated. To the outside end of the
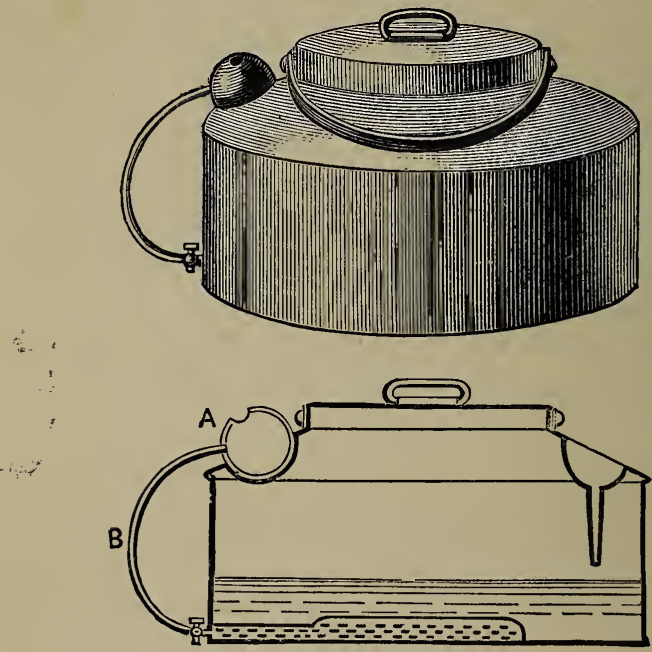

FISH CARRIER.

pipe is attached an india-rubber tube and ball $\mathrm{A}, \mathrm{B}$; by simply squeezing the ball, fresh air can easily be pumped into the can in a continuous stream. If you have no ball, a pair of bellows will do equally well. The advan- 
tage of this can is that you can take it into the railway carriage with you, and by working the ball with your foot can keep up a continuous supply of air to the fish in the can.

This can will also be found exceedingly useful to jack fishers to carry their baits. Wishing that this new form of carrying can should be known as widely as possible among those interested in fish breeding, I instructed Mr. Edon, at my Fish Museum, South Kensington, to look out for a tinsmith who would undertake to construct these cans upon the plans which I had given him. This has now been done, and the can may be obtained at a reasonable cost, of any size from the small ones to carry fry or jack bait, up to large ones suitable for the transfer of two and three year old trout or fontinalis, perch, carp, golden tench, \&c.

Finally, I give the names and addresses of the principal dealers from whom fish eggs may be obtained, and who will be always willing to forward their price lists :

Armistead, I, Troutdale Fishery, Keswick.

Andrews, T., Westgate House, Guildford.

Capel, C., The Fishery, Foot's Cray, Kent.

Guy, J. R., Howietown Fishery, Stirling.

Searle, E. W., 73, Arlington-road, Mornington

Crescent, N.W.

Should beginners at fish-breeding find any hitch or difficulty in their first attempts, they should go down to my Museum of Economic Fish Culture, South Kensington, where the attendant, Mr. Edon, has my orders to supply any information required. 



\section{INDEX.}

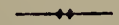

A.

Abbey Tintern (Walley) Salmon, 311

Acclimatisation, Fish fit for, 344

Africa Gilthead Bream, 28

American Black Bass, 362

American Cat-fish, 369

Anatomy of Salmon, 296

Anchovies, 2

Anchovy, 1

Angel-fish, 140, 141

Anglesea Morris, 87

Angler-fish, Large Devonshire, 5

Angler-fish, Food of, 5

Angler, 3

Angling for Bream in Norfolk, 33

Angling for Carp, 39

Angling for Gudgeon, 101

Apprentices and Salmon, 312

Artificial breeding of Sal-

$$
\text { mon, } 387
$$

Argentine, 333

Architecture of fish, 26

Atherine, 6

Azurine, 207
D.

Ballantrae Herring Fisheries, 113, 114

Barbel, 7

Barrel of Herrings, 119

Bass, 152

Basking Shark, Structure, 216

Basking Shark, British Museum, 215

Basking Shark, Irish Fisheries, 216

Basking Shark, Isle of Wight, 215

Beardless Ophidium, 88

Becker, 27

Bergylt, 22

Bergen, Ribbon-fish at, 198

Beuckel, Inventor of salted Herrings, 119

Bimaculated Sucker, 96

Black Fish, 22

Black Bass, American Naturalisation of, 362

Bleak, 14

"Scales made into Pearls, 15

Blenheim, Lake Pike in, 159 
Blennies, 19

Blue Gown, 295

Blue Wrasse, 287

Boar-fish, 77

Bone-dog, 74

Bonito, 272

Borer, 144

Braize, 27

Bream, Aged, 34

$\begin{array}{ll}" & \text { Sea, 26 } \\ \text { " } & \text { Freshwater, } 33 \\ \text { Gilthead, 28 } \\ \text { " Rays, 32 } \\ \text { Monster Norwich, } \\ \text { 34 }\end{array}$

Breeding of Minnows, 139

, $\quad$ of Gold Fish, 99

" Troughs for Salmonidæ, 388

Brighton, Mackerel at, 131 Brill, 175

Bufonites, 30

Bull Head, Sea, 25

Bull Head, 23

Bull Head, choking Grebe, 24

Bull rout, 25

Bull Trout, 320

Buntings, 283

Burbolt, 35

Butter-fish, 20

Butterfly Fish, 20

C.

Calves' tail Bait for Pike, 161

California Pits, 185

Captain, Long fin, 105

Carter, 175

Carp, 36

,, Golden, 98
Carp, Bait for, 40

,, Number of Eggs in,38

, Angling for, 39

" Ponds, 37

, Food of, 40

" Prussian, 41

"Spiegel, 361

Cat-fish, 41

$$
\begin{array}{cl}
, & \text { Food of, } 43 \\
, & \text { Habits of, } 43 \\
& \text { American, } 369
\end{array}
$$

Cathedrals and Salmon, 309

Caviare, 256

Chads, 27

Charr, 323, 349

Charr, Present law concerning, 326

Charr,Summaryof Species, 329

Chimæra, Northern, 46

China,Fish culture in, 372 Chub, 43

, Habits of, 45

, Bait for, 46

" Difference from Dace, 44

Cock-paddle, 125

Cod, 50

Cod, Contents of Stomach of, 51

Cod, Keys found in Stomach of, 51

Cod Destroyed by Ramper Eel, 145

Cod, Lamperns bait for, 124

Cod, Destroyed by Borers, 145

Cod, Tethered by Tail, 58 Cod alive at Grimsby, 57 
Cod, Bait for, 59

Cod Pond at Port Legan, 51

Cod and Viper, 55

Cod, Monster, 51

Cod and Salmon, 56

Cod, Number of Eggs in, 57

Cod, Australian Murray, 364

Colic Stones, 135

Columbia, Viviparous Fish from, 21

Common Trout, 314

Conger, 60

Conger, Habits of, 62

Conger, Monster Southport, 61

Conger, Record of large, 62

Conger at Folkestone, 64

Conger, Weight of largest, 62

Conger, Number of Eggs, 60

Conger nipped by Frost, 65 Cooking Lampreys, Receipt for, 123

Coquet, Bull Trout in, 320

Corkwing, 287

Cornish Sucker, 94

Cornish Anchovy Fishery, 2

Cornish Pilchard Fisheries, 162

Cornwall, Anchovies caught in, 3

Country, Carp Angling in the, 39

Cran of Herrings, 119

Crooner, 105
Cross lining for Chub, 46

Crucian Carp, 41

Crown of King of the

Herrings, 48

Crown fulls, 114

Cumberland Lake, preservation of, 324

D.

Dab, 176

Dace, 66

Dace in Thames, 67

Dace, Live, Baiting with, 67

Deal-fish, 196

Design in Teeth of Bream, 31

Destruction of Sea Fish Fry by Trawl Nets, 188 Devourer, 14.5

Disease in Salmon, Report of, 314

Dog-fish, 68

Dog-fish, Varieties of, 68

Dog-fish Puppies, 72

Dog - fish, Fisherman's names for, 69

Dog-fish, Viviparous, 72

Dog-fish at Folkestone, 69

Dory, John, 76

Dragonets, 96

Ducks good for Ponds, 341

Dubravius on Fishponds, 335

Duke of Edinburgh's Pike, 155

Dutch Coast, Soles on, 184

Dunn, Matthias, Observations on Young Soles, 187 
E.

Ear bones of Maigre, 137

Early-run Salmon, 307

Economic Fish Culture, Museum of, 381

Eels, 79

Eels, Structural beauties of, 83

Eels, Records of large, 82

Eels, Monster, 82

Eels, Cruelty to, in packing, 81

Eels and Thunder, 81

Eels, Gills of, 84

Eels, Scales of, 85

Eels, Varieties of, 79

Eels, Nets in Severn, 81

Eggs in Cod, 57

Eggs, Number in Carp, 38

Eggs in fish, Number of, 387

Eggs, Number in Pike, 155

Eggs of Barbel, 8

Eggs of Lump Fish, 126

Eggs of Conger, 60

Eggs of Troutand Salmon, where to procure, 407

Elleck, 103

Elvers, Passes for, 82

Enquiry, Herring Fisheries, 112

Exeter, Lord, Introduction of Black Bass by, 362

Eye Guard of Eels, 85

"Eye" of Herring, 117

F.

Fairy Stories and Carp, 40,41

Father-lasher, 25
Fat on Pyloric Appendages of Salmon, 297, 304

Fattening Grounds for Salmon, 299

Feeding times of Perch, 149

Fiddler-fish, 140

File-fish, 88

Findon Haddies, 108

Fish, Number of Eggs in, 387

Fish Track, Fossil, 107

Fish fit for Acclimatisation, 344

Fishing for Gudgeon, 101

Fish, How to Cook out of doors, 150

Fishing Frog, 3

Fish culture in China, 372

Fish culture, Museum of Economic, 381

Fish for Acclimatisation, 344

Fish-ponds, Cultivation of in Queen Anne's time, 339

Fish-ponds, Cultivation of, 334

Fisheries, Freshwater Act, 376

Flounder, 176, 350

Folkestone, Conger at, 64

Folkestone, Dog-fish at, 69

Fontinalis, 345

Four large Salmon from Tay, Weight of, 295

Food of Salmon, 298

Forkbeard, Varieties of,111

," Lesser, 111

Freshwater Fisheries Act, 376 
French Fïshermen and Dog-fish, 65

Frost, Effect on Fish, 66

Fry of young Salmon and Trout, Proper Food for, 400

Fry of young Salmon and Trout, When to turn out, 402

Fry of Young Salmon and Trout, Management of, 398

Fungus on Carp, 38

Gar-pike, 90

$$
\text { G. }
$$

Habits of, 91

Gäries, Cran of, 119

Gentles, To keep during winter, 206

Gillaroo Trout, 321

Gilthead, 28-29, 287

Glass Catchers, 392

Glutinous Hag, 144

Globe-fish, 92

Gobies, 93, 283

Golden Eels, 80

Gold-fish, 98

$\begin{array}{ll}\text { " } & \text { Varieties of, } 100 \\ \text { " } & \text { Care of, } 98 \\ \text { Food for, } 268 \\ \text { Breeding of, } 99\end{array}$

Golden Tench Naturalised at Aldermaston Park, 359

Goldsinny, 287

Gorebill, 90

Gourami, 369

Great Lake Trout, 322

Great Lake Trout, Artificial breeding of, 347
Grayling, 330

Grebe choked by a Bullhead, 24

Greenland Shark, Habits of, 213

Greenbone, 90

Grimsby, Cod boxes at, 57

Gudgeon, 100

" Evidence by, 103

, Fishing, 101

Gurnards, 103

Varieties of, 105
Gurnards, Walking on sand, 106

Gwyniad, 327

Gymnetrus Arcticus, 196

H.

Habits, Curious of Gudgeon, 102

Haddock, 108

Hag Glutinous, 144

Hair-tails, 199

Hair of Queen's Horses for Roach Fishing, 206

Hake, 110

Hakes' teeth, 110, 384

Halibut, 177

, Fisheries, 178

Hardhead, 26, 105

Habits of Herrings, 116

Heart in Eel's tail, 86

Herring, 112

Herring Export to Continent, 114

Herring Commissioners, 112

Herring Commissioners' conclusions, 115 
Herring, Scotch Fisheries, 113

Herrings, large fall out of net, 118

Herrings, Shoal, length and width of, 118

", Measurements, 119

" Nets, 117

" Salted, 119

", Shoals of, 116

" King of the, 47

Hippocampus, 171

Hoe Dogs, 74

Hooknose, 26

Horse Mackerel, 133

Hose nets, Bridgwater, 299

\section{AND J.}

Ichthyopatolites, 107

Ireland, Net fisheries of, 81

Jardine's Monster Pike, 156

Jerusalem Haddock, 146

K.

Kettle Nets, Rye, 132

King of the Herrings, 46

King-fish or Opah, 146

Lamprey, 120

\section{L.}

Lamprey, Structure of, 121

Lamprey, Severn season for, 122

Lamprey, Fatal to Henry I., 122

Lamprey, Season for, 122 Lamprey, Receipt how to cook, 123
Lamprey, Sea, 120

Lampern, 124

Lampern, Bait for Cod, 59, 124

Lampern, Bait for Turbot, 124

Lampern, Fishery on Trent, 124

Lancelet, 88

Last of Herrings, 119

Launce Sand, 208

Lawyers and Gudgeon, 103

Lemon Sole, 173

Lesser Fork Beard, 111

Licenses, Trout, 316

Ling, 127

" As food, 128

" Large, at Wick, 129

", Stornoway, 129

Lines attached to Cod, 58 Loach, 130

Loch Fyne Herrings, 114

Loch Leven Trout, 322, 349

Locking fin of File-fish, 89

Lost Herrings, 118

Lump-sucker, 125

Lump-fish, Large, 126

Lythe, 190

Mackerel, 131

Mackerel and Gorebill, 90 Mackerel, Spawning and Growth, 132

Mackerel, Express trains with, 131

Mackerel Midge, 134

Mackerel, Horse, 133 
INDEX.

Maigre, 134

Maigre, Earbones of, 137

Maigre, Gullet teeth of,136

Maigre, Monster, 136

Maize of Herrings, 119

Mary Sole, 175

Margate, Tunny Skull at, 272

Matties, 113

McDonald, Capt., Herrings Evidence, 118

Measurements of Herrings, 119

Melbourne, Trout at, 318

Microscope, Young Salmon under, 396

Midge Mackerel, 134

Migration of Salmon, Spring and Autumn, 309

Miller's Thumb, 2ə

Minnow, 137

Minnow, Spawning dress, 137

Minnow, Eggs how to procure, 139

Minnow, Served to William of Wykeham, 138

Minnow, Valuable as fish food, 138

Monk-fish at Yarmouth, 140

Monk-fish at Southport, 141

Monks and Carp, 37

Monks and Salmon, 311

Monster Cod, 51

, Trout, 315

", Conger, 61

, Sturgeon, 253

Morris Anglesea, 87
Mullet, 142

, Bait for, 143

, Habits of, 143

Mullet, Escaping from net, 143

Muræna, 86

Murray Cod, Australia, 364

Myxine, 144

N.

Names of Salmon, Various, 314

Nest, Five Bearded Rockling, 204

Nets, Length of Herring, 117

Nets, Pilchards, 164

Nets, Tuck, 165

Nets, Fleet of Herring, 117

Neuchâtel, Burbot in Lake at, 35

New Zealand, Salmon sent to, 319

Norfolk, Angling for Bream in, 33

North Sea, Sole Fisheries in, 185

Nostril of Salmon, 301

Nose of Dog-fish, 71

Nottingham, Worm Farm at, 10

Number of Eggs in Fish, 387

Nursery for Young Trout, 389

0 .

Oats for Mud in Cleansing Ponds, 337 
Esophagal Teeth of Salmon, 296

Opah, 146

Ophidium, Beardless, 88

Orient Pearls of Bleak Scales, 15

Orfe, The Golden, 360

Orkney, Ribbon-fish at, 198

Osiers for Mud of Drying Ponds, 337

Oxford, Bleak at, 15

\section{P.}

Packs of Dog-fish, 73

Paradise-fish. 366

Pearls of Bleak Scales, 15

Pelamid, 274

Perch, 147

, I Large, 151

, To Cook, 150

, Weapons of, 148

, Intelligence of, 151

" Habits of, 149

, Sea, 152

Pike, 153

Pike, Prince Christian's from Windsor, 154

Pike, Duke of Edinburgh's, 155

Pike at Blenheim, 159

Pike, Mr. G. Rooper's, 159

Pike, Mr. Jardine's, 155

Pike in the Avon, Hants, 159

Pike, Eggs in, 154, 155, 159

Pike swallowing Pike, 160

Pike, Teeth of, 161

Pike-Perch, 350

Piked-dog, 74, 75

Pilot-fish, Structure of, 166

Pilchard, 162

Pilchard Nets, 164

Pilchard Fisheries, Cornwall, 162

Pilchard, How to tell from a Herring, 162

Pilchard, Curing, 163

Pipe-fishes, 167

Piper, 104

Pocket-fish, 3

Pogge, 26

Poison Ramper, 144

Poison Ramper or Weever Fish, 275, 276

Pollan, 326

Pollack, 190

Polwigs, 283

Ponds and Ducks, 341

Pond-fish, Proper treatment of, 336

Pope, 190

Porbeagle Shark, 217

Port Logan, Cod-fish at, 51

Pout or Bib, 192

Powan, 327

Protestant Countries Import Herrings, 119

Prussian Carp, 41

Pylorics, Fat Stored on Salmon, 304

Pyloric, Appendages of Salmon, 297

$\mathrm{R}$.

Rabbit-fish, 46

Ray's Bream, 31

Reading, Large Trout at, 316 
Regalecus Banksii, 197

Remora, 193

Remora, Emblem of Prudence, 194

Report, Herring Commissioners', 115

Report, Salmon Fisheries, Rhine Salmon clean in November, 308

Ribbon-fishes, 195

Rigs at Folkstone, 70

Roach, 204

Roach, Art of Angling for, 205

Roach, Baits for, 206

Roach, Disease of, 206

Roach, How to tell from Rudd, 208

Robinson Crusoe's Experiences of Pout Fishing, 193

Rocklings, 202

Roman Catholic Countries Import Pilchards, 119

Rooshians, 283

Rooper's, G., Large Pike, 159

Rough Hound, 73

Rudd, 207

$$
\text { Eggs of, } 73
$$

Rudd, To tell from Roach, 208

[207

Rudd Fishing in Norfolk, Ruff, 190

Russia, Pike Perch from, Rye, Kettle Nets at, 132

S.

Sachs on Pearl Making, 15 Sachs on Transport of Living Pike Perch, 350
Salmonidæ, Artificial breeding of, 387

Salmon, Young, 394

" Anatomy of, 394

Salmon, 289

Salmon, Stomach of, 296

Salmon and Dace, 152

Salmon and Cod, 56

Salmon and Apprentices, 312

[295

Salmon from Avon, Hants,

Salmon, Monster, 291

Salmon, List of Monster, 292

Salmon Giant, From the Tay, 293

Salmon Large, From the Shannon, 294

Salmon, and Cathedrals, 309

Salmon and Monks, 311

Salmon $v$. Sheep Value, 300

Salmon, Number of Eggs in, 289

Salmon, Migrations of, 290

Salmon, Police of Nature, 291

Salmon, Anatomy of, 296

Salmon kept back by Pollutions, 302

Salmon, Life of, 289

Salmon, Smelling Powers of, 301

Salmon, Evidence and Design, 290

Salmon, Unclean and Unseasonable, 303

Salmon, Various Names of, 314 
Salmon breed should be Exchanged, 344

Salmon to New Zealand, 319

Salmon Fisheries Report, 314

Salmon Rivers, General Report on, 313

Salmon Disease Report, 314

Salmon Law, Manual of, 377

Salmo Hucho, 345

Sand Eel, 208

"Smelt, 6

" Pride, 124

", Eels, Habits of, 209

Sandra, 350

Sapphirine Gurnard, 104

Saury Pike, 92

Saw in Barbel's fin, 8

Scabbard-fish, 202

Scad, 133

Scales, Pearls of Bleak, 15

Scald-fish, 175

Schlei, Golden, 359

Sea Bream, 26

Sea Fox, Shark, 218

Sea Gudgeons, 93

Sea Needle, 90

Sea Perch, 152

Sea Horses, Hippocampi,

\section{1}

Sea Sheep, 135

Sea Snipe, 269

Sea Serpent Exhibited in Regent Street, 199 Sea Voyages, Observations

Required on, 272

Sea Trout, 322

Sewen, 322
Shad, 210

Shad Fisheries of Severn, 211

Shanny, 19

Sharks, 211

Shark fisheries,Iceland,214

Shark, Blue, 212

Sheat-fish, 357

Sheffield Angling Matches, 191

Shoals, Enormous of Herrings, 118

Shovel Nosed-dog, 71

Shrimps, Red, 283

Silurus Glanis, 357

Silurus to Mr. H. Burrs, 358

Silvery Hairtails, 200

Silver Pits, Soles in, 185

Skipper, 92

Smelts, 331, 349

Smelt Fisheries, 382

Smelling Powers of Salmon, 301

Smig Bait, 282

Smooth-hound, 75

Snake Pipe-fish, 169

Snig Eels, 80

Sole, 184

," Variegated, 174

Soles, Migrations of, 185

" Monster, 186

", on Doggerbank, 185

", Torbay, 186

", Food of, 186

", Swim on Side, 187

, Eggs of, 187

Soles, Young, Remarkable Mode of Swimming, 187 Soles, Small, Wanton Destruction of, 189 
Soles, Small, Destroyed by Trawl Net, 188

Solenette, 174

Soundings, Hakes' Teeth, 110, 384

Sounds made by Maigre, 136

Sparlings, 331

Spectacles of Eel, 85

Spiegel Carp, 361

Spotted Gunnel, 20

Sprats used for Anchovies, 3

Spratty Stuff, 282

Spring Salmon, 307

St. Mary's Trout, 203

St. Peter's Fish, 76

Sting Bull, 274

Stonebiter, 35

Stone Clagger, 125

Stocking Ponds with Carp, 338

Structural Beauties of the Eel, 83

Sturgeons, 252

" Shackles of, 256 Suckers, Varieties of, 96

Sucker, Cornish, 94

Sucker, Unctuous, 96

Sucking-fish (Remora), 194

Sun-fish, America, 368

Sun-fish, 257

Tadpole Fish, 111

Tails, Prehensile of Pipefish, 169

Tame Cod-fish, 53

Tasmanian Establishmeit of Trout, 318
Taverner on Fish-ponds, 335

Tay, Large Salmon from, 295

Teeth, Gilthead Bream, 29

" Hakes', 384

,, Throat of Barbel, 9

Telescopes, Water, 379

Thresher Shark, 218

Thresher Shark, Size and Structure of, 219, 220

Thresher Shark Fighting a Whale, 385

Throat, Teeth of Barbel, 9 Thurso, Ribbon-fish from, 196

Toad-stones, 30

Tom Culls, 24

Tom, the Blind Cod, 53

Tope, or Toper Dog-fish, 75

Top Knot, 175

Trawl Fish, 172

Trawl Net, Problem as to Mesh of, 189

Treatment of Golden Carp, 98

Trout, Common, 314

Trout Common, Breeding of, 348

Trout, Nursery for Young, 389

Trout Monster at Alresford, 315

Trout Salmon at Reading, 316

Trout, Loch Leven, 322, 349

Trout, Transfer of, 348

Trout, Bull, 320

Trout at Melbourne, 318 
Trout Licenses, 317

Trout for fish breeding, 388

Trumpet-fish, 269

Tub-fish, 104

Turbot, 182

Turbot, Number of Eggs in, 183

Turbot, Fisheries for, 183

Tunny, 270

Umber, 330

\section{$\mathrm{U}$.}

Unctuous Sucker, 96

Unclean and Unseasonable Salmon, 303

Unseasonable and Unclean Salmon, 303

Use of Pyloric Fat in Salmon, 305

$\mathrm{V}$.

Vaagmaer, 196

Value of Whitebait, 278

Vendace, 328, 348

Viviparous Blenny, 21

Viviparous Dog-fish, 72

W.

Walpole's Manual of Salmon Law, 377

Warm Water, Gold-fish Breeding in, 99

Water Pouches of Eels, 84

Water Bones, 103

Water Telescopes, 379

Weever, 274
William of Wykeham and Minnows, 138

Winchester, Tom Culls at, 24

Windsor, Carp at, 38

Windsor, Rapley Lake Pike, 154

Whale and Thresher, 385

Whitebait, 277

Whitebait, Where Caught, 277

Whitebait, Antiquity of, 278

Whitebait, Origin of Name, 280

Whitebait, what is it, 281

Whitebait Fishing should not be stopped, 284

White Salmon, 152

Whiff, 175

Whiting, 284

Woburn Abbey, Golden Orfe at, 360

Woburn Abbey, Zander at, 354

Wolf Fish, 41

Worm Catching, 11

Worm Farm at Nottingham, 10

Worms for Barbel Fishing,

Wrasse, 285

Wrasse, How to Fish for, 286

Yawlings, 282 


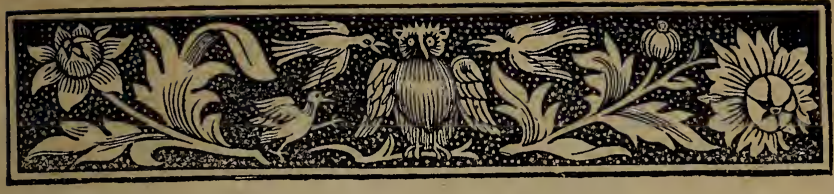

\title{
IOUBLICATIONS
}

\author{
OF THE
}

\section{Society • for • Promoting • Christian • Knowledgé.}

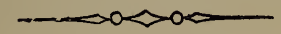

\section{HISTORY OF INDIA.}

From the Earliest Times to the Present Day. By Captain L. J. TROTTER, Author of "Sequel to Thornton's History of India." With eight full-page Woodcuts on toned paper, and numerous smaller Woodcuts. Post 8vo. Cloth boards, ros. 6d.

\section{STUDIES AMONG THE PAINTERS.}

By J. B. Atkinson, Esq. With seventeen full-page Illustrations. Small Post 4to. Cloth boards, 7s. 6d.

\section{BEAUTY IN COMMON THINGS.}

Illustrated by twelve Drawings from Nature, by Mrs. J. W. WHYMPER ; Printed in Colours, by WILliaM DICKES. With descriptive Letterpress, by the Author of "Life in the Walls," "Robin the Bold," \&c. Demy 4to. Cloth boards, Ios. 6d.

\section{SCENES IN THE EAST.}

Consisting of twelve Coloured Photographic Views of Places mentioned in the Bible, beautifully executed, with Descriptive Letterpress. By the Rev. CANON TRISTRAM, Author of "Bible Places," "The Land of Israel," \&c. 4to. Cloth, bevelled boards, gilt edges, $7 \mathrm{~s} .6 \mathrm{~d}$. 


\section{SINAI AND JERUSALEM; OR, SCENES FROM BIBLE LANDS.}

Consisting of Coloured Photographic Views of Places mentioned in the Bible, including a Panoramic View of Jerusalem with Descriptive Letterpress. By the Rev. F. W. Holland, M.A., Honorary Secretary to the Palestine Exploration Fund. Demy 4to. Cloth, bevelled boards, gilt edges, 7s. 6d.

\section{BIBLE PLACES ; OR, THE TOPOGRAPHY OF THE HOLY LAND.}

A succinct account of all the Places, Rivers, and Mountains of the Land of Israel mentioned in the Bible, so far as they have been identified; together with their modern names and historical references. By the Rev. CANON Tristram. With Map. A new and revised edition. Crown 8vo. Cloth boards, 4s.

\section{THE LAND OF ISRAEL.}

A Journal of Travel in Palestine, undertaken with special reference to its Physical Character. By the Rev. Canon TRISTRAM. Fourth edition, revised. With Maps and numerous Illustrations. Large post 8 vo. Cloth boards, Ios. 6 d.

NARRATIVE OF A MODERN PILGRIMAGE THROUGH PALESTINE ON HORSEBACK, AND WITH TENTS.

By the Rev. Alfred Charles Smith, M.A., Rector of Yatesbury, Wilts, Author of "The Attractions of the Nile," \&c. Numerous Illustrations and four Coloured Plates. Crown 8vo. Cloth boards, 5 s.

\section{THE NATURAL HISTORY OF THE BIBLE.}

By the Rev. Canon Tristram, Author of "Bible Places," \&c. With numerous Woodcuts. Crown 8 vo. Cloth boards, 7s. 6d.

\section{A HISTORY OF THE JEWISH NATION.}

From the Earliest Times to the Present Day. By the late E. H. Palmer, Esq., M.A., Fellow of St. John's College, Author of "The Desert of the Exodus," \&c. With Map of Palestine and numerous Illustrations. Crown 8 vo. Cloth boards, $4 \mathrm{~s}$. 


\section{BRITISH BIRDS IN THEIR HAUNTS.}

Being a Popular Account of the Birds which have been observed in the British Isles; their Haunts and Habits ; their systematic, common, and provincial Names; together with a Synopsis of Genera; and a brief Summary of Specific characters. By the late Rev. C. A. JoHnS, B.A., F.L.S. Post 8vo. Cloth boards, Ios.

\section{THE CYCLE OF LIFE.}

A Book of Poems for Young and Old, Town and Country. Printed on toned paper. Illustrated with eighteen Woodcuts. Fcap. 4to. Handsomely bound in cloth, gilt edges, bevelled boards, $5 \mathrm{~s}$.

\section{THE ART TEACHING OF THE PRIMITIVE CHURCH.}

With an Index of Subjects, Historical and Emblematic. By the Rev. R. St. JoHN TyRwhitT. 7s. 6d.

\section{AFRICA, SEEN THROUGH ITS EXPLORERS.}

By Charles H. EdeN, Esq. With Map and several Illustrations. Crown 8vo. Satteen cloth boards, 5s.

\section{AFRICA UNVEILED.}

By the Rev. H. RowLey. With Map, and eight full-page Illustrations on toned paper. Crown 8vo. Cloth boards, $5 \mathrm{~s}$.

\section{AUSTRALIA'S HEROES:}

Being a slight Sketch of the most prominent amongst the band of gallant men who devoted their lives and energies to the cause of Science, and the development of the Fifth Continent. By C. H. EDEN, Esq., Author of "Fortunes of the Fletchers," \&c. With Map. Crown 8vo. Cloth boards, 5 s.

\section{SOME HEROES OF TRAVEL; OR, CHAPTERS FROM THE HISTORY OF GEOGRAPHICAL DISCOVERY \& ENTERPRISE.}

Compiled and re-written by W. H. DAVENPORT ADAMS, Author of "Great English Churchmen," \&c. With Map. Crown 8vo. Satteen cloth boards, $5 \mathrm{~s}$. 


\section{CHRISTIANS UNDER THE CRESCENT IN ASIA.}

By the Rev. EDWARD L. CUTTS, B.A., Author of "Turning Points of Church History," \&c. With numerous Illustrations. Post 8vo. Cloth boards, 5s.

\section{THE FIFTH CONTINENT, WITH THE ADJAGENT ISLANDS.}

Being an Account of Australia, Tasrnania, and New Guinea, with Statistical Information to the latest date. By C. H. EDEN, Author of "Australia's Heroes," \&c. With Map. Crown 8vo. Cloth boards, 5 s.

\section{FROZEN ASIA : A SKETCH OF MODERN SIBERIA.}

By CHARLES H. EDEN, Esq., Author of "Australia's Heroes," \&c. With Map. Crown 8vo. Cloth boards, 5 s.

\section{HEROES OF THE ARCTIC AND THEIR ADVENTURES.}

By FREDERICK WhyMPER, Esq., Author of "Travels in Alaska," \&c. With Map, eight full-page and numerous small Woodcuts. Crown 8 vo. Cloth boards, 3s. 6d.

\section{CHINA.}

By Professor Robert K. DOUglas, of the British Museum. With Map, and Eight full-page Illustrations on toned paper, and several Vignettes. Post 8 vo. Cloth boards, 5s.

\section{RUSSIA : PAST AND PRESENT.}

Adapted from the German of Lankenau and Oelnitz. By Mrs. CHESTER. With Map, and Three full-page Woodcuts and Vignettes. Post 8 vo. Cloth boards, 5 s.

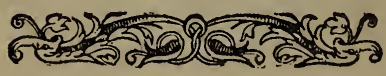

进epasittaries:

NORTHUMBERLAND AVENUE, CHARING CROSS; 43, QUeen Victoria Street; 26, St. George's Place, S.W.; AND 135, NORTh STREet, BRightoN. 



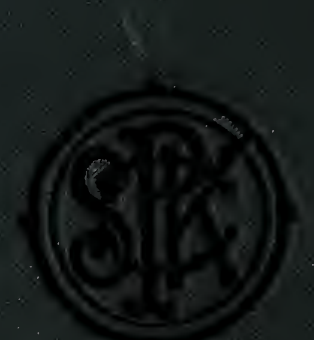

